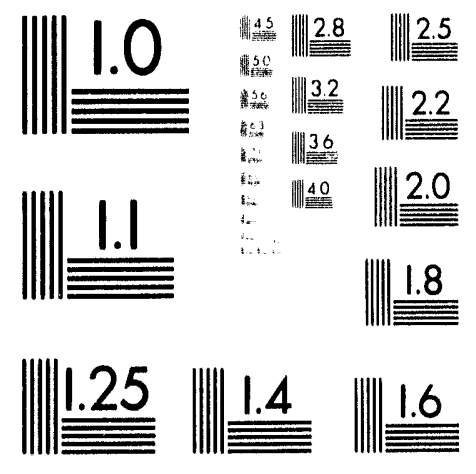



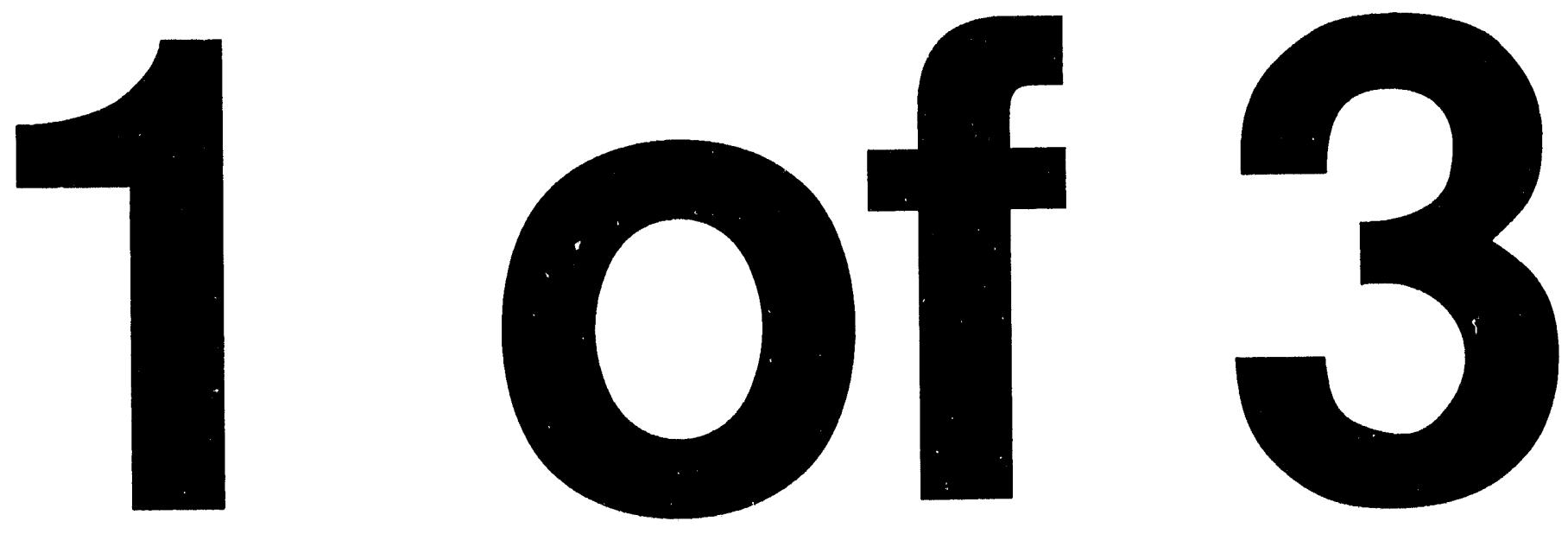


\title{
Quality Assurance Program Plan for Radionuclide Airborne Emissions Monitoring
}

\author{
L. W. Vance
}

Date Published

July 1993

Prepared for the U.S. Department of Energy Office of Environmental Restoration and Waste Management

\section{(2) Westinghouse \\ Hanford Company Richland, Washington 99352}

Hanford Operations and Engineering Contractor for the

U.S. Department of Energy under Contract DE-AC06.87RL10930 


\section{APPROVAL PAGE}

Document Title: Quality Assurance Program for Radionuclide Airborne Emissions Monitoring

Prepared by:

L. W. Vance, Principal Engineer $7 / 22 / 93$

Environmental Management Services Integration

Approved by:

Approved by:

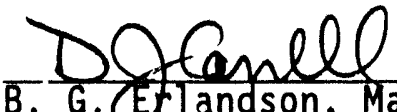

B. G. E. Tlandson, Manager

Reguiatory Field Support

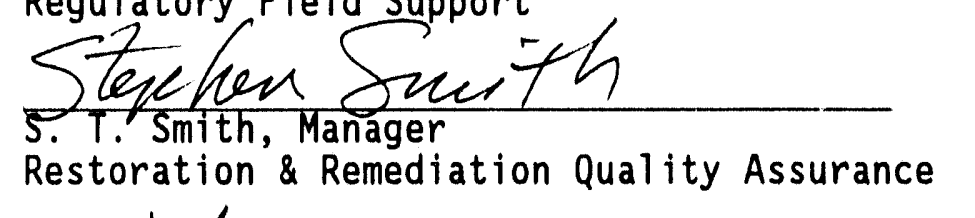

Reviewed by:

J. J. Crane, Manager

T-Plant Environmental Control

Reviewed by:

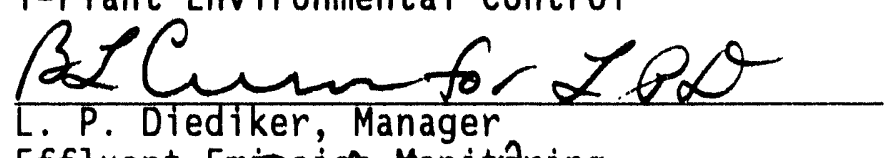

$\frac{7-23-93}{\text { Date }}$

$\frac{7 / 23 / 93}{\text { Date }}$

$\frac{7 / 22 / 93}{\text { Date }}$

$7 / 22 / 93$

Reviewed by:

Effluent Enigs iop Monitagring

R.D. Guster

R. D. Gustavson, Acting Manager

Tank Farm Environmental Engineering

Reviewed by:

$3 \neq C$

felecon

D. L. Halgren, Manager

$\bar{B}-P 1$ ant Environmental Engineering

Reviewed by:

D. J. Mçride, Manager

PFP Environmental Compliance

Reviewed by:

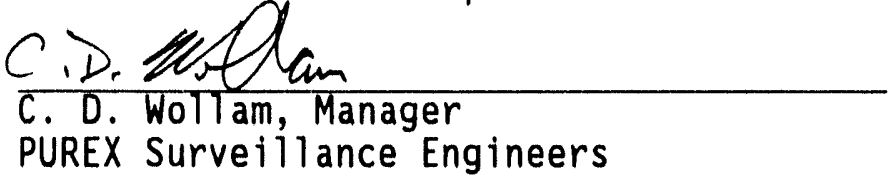

$\frac{7-22-93}{\text { Date }}$

$\frac{7 / 22 / 93}{\text { Date }}$

$7 / 24 / 93$

$\frac{7 / 22 / 93}{\text { Date }}$

$\frac{1 / 22 / 93}{\text { Date }}$ 


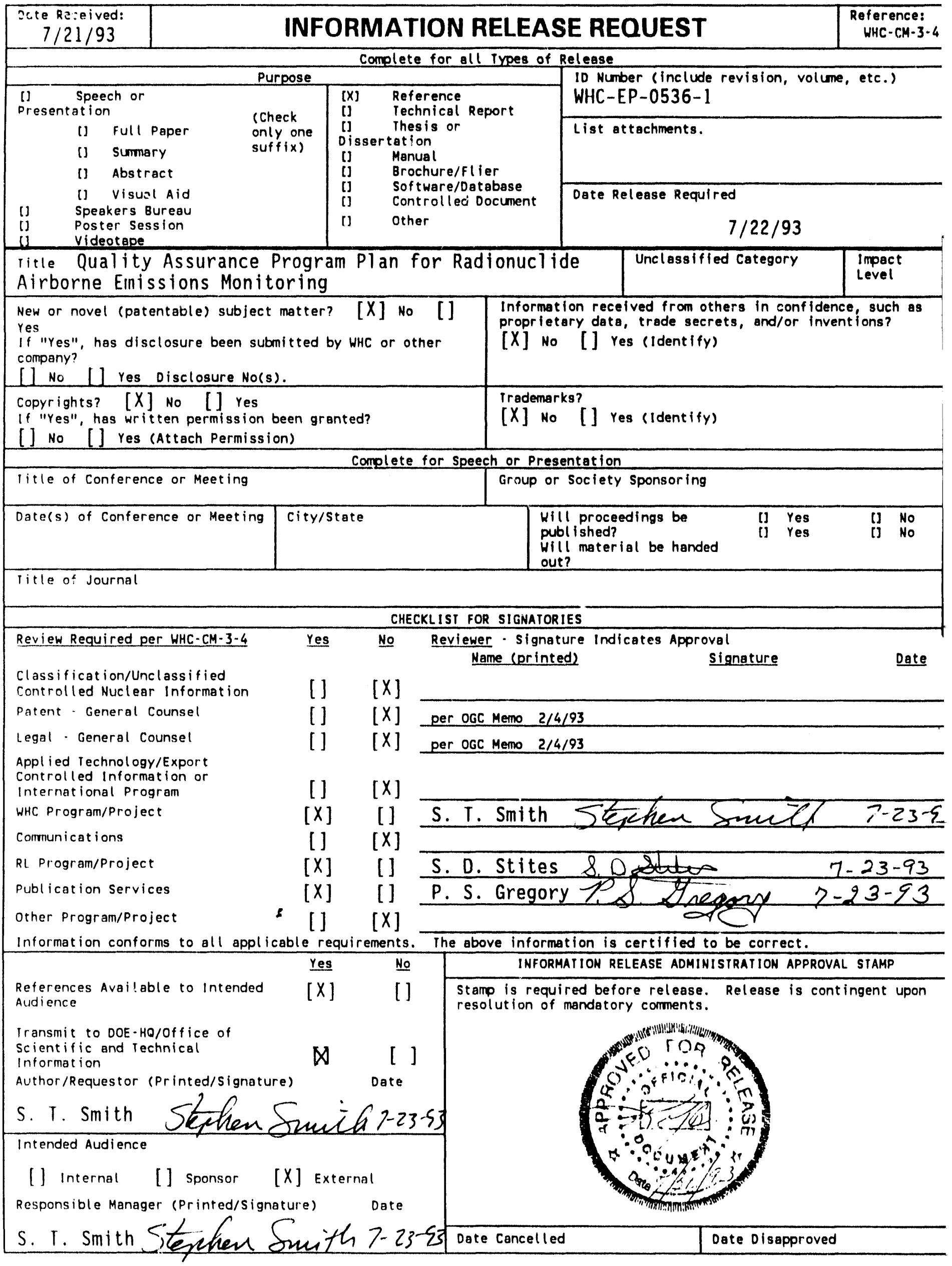


WHC-EP-0536-1

\title{
QUALITY ASSURANCE FOR RADIONUCLIDE
}

AIRBORNE EMISSIONS MONITORING

\author{
L. W. Vance
}

\section{ABSTRACT}

This Quality Assurance Program Plan identifies quality assurance program requirements and addresses the various organizations and their particular responsibilities in regards to sample and data handling of airborne emissions.

The Hanford site radioactive airborne emissions requirements are defined within Title 40, Protection of the Environment, Code of Federal Regulations, Part 61, "National Emissions Standards for Hazardous Air Pollutants," Subpart H, (EPA 1991). Reporting of the emissions to U.S. Department of Energy is performed in compliance with requirements of U.S. Department of Energy Order 5400.1, General Environmental Protection Program (DOE 1988a).

This Quality Assurance Program Plan, is prepared in accordance with and to the requirements of QAMS-004/80, Guidelines and Specifications for Preparing Quality Assurance Program Plans (EPA 1983).

Title 40 CFR Part 61, Appendix B, Method 114, "Quality Assurance Methods," specifies the quality assurance requirements and that a program plan should be prepared to meet the requirements of this regulation. This document idcntifies NESHAP responsibilities and how the Environmental, Safety, Health, and Quality Assurance Division will verify that the methods are properly implemented. 
WHC-EP-0536-1

This page intentionally left blank. 


\section{CONTENTS}

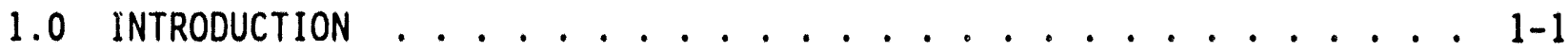

2.0 QUALITY ASSURANCE POLICY STATEMENT . . . . . . . . . . 2-1

3.0 ENVIRONMENTAL, SAFETY, HEALTH,

AND QUALITY ASSURANCE MANAGEMENT . . . . . . . . . . . 3-1

3.1 ESQ COMPLIANCE ASSURANCE ............. 3-1

3.1.1 Environmental Compliance Assurance . . . . . . . . 3-1

3.1.2 Quality Compliance Assurance . . . . . . . . 3-1

3.2 QUALITY ASSURANCE .................. 3-2

3.2.1 Environmental Management Systems Integration ..... 3-2

3.2.2 Environmental Services Quality Assurance . . . . . . 3-2

3.2.3 Support Quality Assurance ............. 3-3

3.2.4 Quality Assurance Standards and Requirements ..... 3-3

3.2.5 Facility Quality Assurance ......... 3-3

3.2.6 Tank Waste Remediation System Quality Engineering . . 3-3

3.2.7 Engineering Applications Quality Assurance ..... 3-3

3.2.8 Waste Operations Quality Assurance ........ 3-4

4.0 DOCUMENT CONTROL AND RECORDS ................ 4-1

4.1 QUALITY ASSURANCE . . . . . . . . . . . . . . . . 4-1

4.2 ESQ COMPLIANCE ASSURANCE .............. . . 4-1

4.2.1 Environmental Compliance Assurance . . . . . . . 4-1

4.2.2 Quality Compliance Assurance ........... 4-1

5.0 ORGANIZATION AND PERSONNEL QUALIFICATIONS . . . . . . . . . 5-1

6.0 RADIOACTIVE AIR EMISSIONS MEASUREMENT QUALITY

6.1 INTRODUCTION

6.2 ORGANIZATION AND RESPONSIBILITIES . . . . . . . . . . . 6-1

6.2 .1 Health Physics ............. . 6-2

6.2 .2 Laboratories . . . . . . . . . . . . . 6-6 6-2

6.2 .3 Regulatory Analysis ............ 6- 6-3

6.2.4 Regulatory Program Integration . . . . . . . 6-3

6.2 .5 Effluent Emission Monitoring . . . . . . . . . . 6-3

6.2.6 Central Support Services . . . . . . . . . . 6-6 6-4

6.2 .7 Facilities............... . . 6-4

6.2 .8 Other Support Contractors . . . . . . . . 6-5

7.0 ORGANIZATIONAL CHARTS AND FIGURES ............ . 7-1

8.0 PERFORMANCE AND SYSTEM AUDITS . . . . . . . . . . . . . . 8-1

9.0 CORRECTIVE ACTION ...................... . . . . .

10.0 QUALITY ASSURANCE REPORTS .............. . . 10-1

11.0 REFERENCES .................... . . . . . 
WHC-EP-0536-1

\section{CONTENTS (Continued)}

APPENDICES
A METHOD 114 COMPARISON FOR STACK $291-A-1 \ldots \ldots \ldots$. . . . . . . A
B METHOD 114 COMPARISON FOR STACK $291-B-1 \ldots \ldots$. . . . . . . B-1
C METHOD 114 COMPARISON FOR STACK 291-Z-1 ............. C-1
D METHOD 114 COMPARISON FOR STACK $296-A-22 \ldots \ldots \ldots$. . . . . . . . D
E METHOD 114 COMPARISON FOR STACK $296-A-40 \ldots \ldots$. . . . . . . E-1
F METHOD 114 COMPARISON FOR STACK 340-NT-EX . . . . . . . . . F-1
G METHOD 114 COMPARISON FOR THE $222-S$ LABORATORY . . . . . . . . G-1
H METHOD 114 COMPARISON FOR 325 LABORATORY . . . . . . . . . . . H-1
I METHOD 114 COMPARISON FOR STACK 291-T-1 ............ I-1 
WHC-EP-0536-1

\section{LIST OF FIGURES}

1 Organizational Chart for WHC Senior Management ......... 7-3

2 Organizational Chart for ESI Compliance Assurance . . . . . . 7-5

3 Organizational Chart for Quality Assurance . . . . . . . . . 7-7

4 Organizational Chart for Health Physics . . . . . . . . . 7-9

5 Organizational Chart for Restoration \& Remediation ........ 7-11

6 Organizational Chart for Facility Operations .......... 7-13

7 Organizational Chart for Operations Support Services . . . . . . 7-15

8 Emission Sampling and Analytical Implementation ........ . 7-17 


\section{LIST OF TERMS}

CFR

CSS

DOE

ECA

EEM

EMSI

EPA

ESH/QA

ESQA

ESQD

FQA

JCS

NESHAP

PAL

QA

QAPJP

QAPP

QASR

QCA

QC

QI

QR

RA

RPI

RR

SQA

TWRS

WHC

$\mathrm{WDOH}$
Code of Federal Regulations

Central Support Services

U.S. Department of Energy

Environmental Compltance Assurance

Effluent Emission Monitoring

Environmental Management Systems Integration

Environmental Protection Agency

Environmental, Safety, Health, and Quality Assurance

Environmental Services Quality Assurance

ESQ Data

Facllity Quality Assurance

job control system

"National Emission Standards for Hazardous Air Pollutants"

Processing and Analytical Laboratory

quality assurance

Quality Assurance Project Plan

Quality Assurance Program Plan

Quality Assurance Standards \& Requirements

Quality Compliance Assurance

quality control

Quality Instruction

Quality Requirement

Regulatory Analysis

Regulatory Program Integration

Restoration and Remediation

Support Quality Assurance

Tank Waste Remediation System

Westinghouse Hanford Company

Washington State Department of Health 


\subsection{INTRODUCTION}

This Quality Assurance Program Plan (QAPP) describes the quality assurance requitements and responsibilities for radioactive airborne emissions measurements activities from regulated stacks are controlled at the Hanford site. This QAPP is prepared in accordance with and to the requirements of QAMS-004/80, Guidelines and Specifications for Preparing Quality Assurance Program Plans (EPA 1983).

Radioactive airborne emission measurenent requirements are defined in Subpart $H$ of Title 40, Code of Federal Regulations (CFR), Part 61, "National Emission Standards for Hazardous Air Pollutants" (NESHAP) (EPA 1991). Detalled monitoring requirements apply to stacks exceeding $1 \%$ of the standard of 10 mrem annual effective dose equivalent to the maximally exposed individual from operations of the Hanford Site.

Title 40 CFR Part 61, Appendix B, Method 114, "Quality Assurance Methods," specifies the quality assurance (QA) requirements and that a QAPP should be prepared to meet the requirements of this regulation.

The QAPP will be updated annually or when organizational changes and/or responsibilities warrant a revision. 
WHC-EP-0536-1

This page intentionally left blank. 


\subsection{QUALITY ASSURANCE POLICY STATEMENT}

Westinghouse Hanford Company (WHC) shall maintain and verify a prevention-oriented QA program to ensure that WHC products and services meet requirements, are fit for use, and satisfy customer expectations. As part of prevention orientation, the QA program shall provide measurements of performance, establish criteria, and encourage changes that improve quality and productivity. 


\section{WHC-EP-0536-1}

This page intentionally left blank. 


\subsection{ENVIRONMENTAL, SAFETY, HEALTH, AND QUALITY ASSURANCE MANAGEMENT}

Independent oversight verification activities associated with the radioactive airborne emission measurements are controlled by the ESH/QA Division for WHC. The organizations within this Division that perform these oversight activities, and their interfaces, are figures in Section 7.0.

QA surveillances will be performed and controlled in accordance with WHC-CM-4-2, QUality Requirement (QR) 10.0, "Inspection," and QI 10.4, "Surveillance" (WHC 1988).

The sections that follow describe the responsibilities of these organizations as they relate to radioactive air emissions measurements.

\subsection{ESQ COMPLIANCE ASSURANCE}

The organizational chart for the ESQ Compliance Assurance is referenced in figure number 2.

\subsubsection{Environmental Compliance Assurance}

The Environmental Compliance Assurance (ECA) group maintains and implements a comprehensive environmental oversight program to independently verify that Westinghouse Hanford operations are conducted in compliance with applicable environmental regulations, U.S. Department of Energy (DOE) orders, and Westinghouse Hanford management control systems.

The ECA group schedules and performs oversight activities (audits and appraisals) in accordance with requirements specified in WHC-CM-7-6, Sections 4.0, 5.0, 6.0, 7.0, 10.0, and 13.0 (WHC 1989a), and Quality Instruction (QI), 18.4 of WHC-CM-4-2, Quality Assurance Manual (WHC 1988).

The ECA group will schedule and perform at least one annual audit/appraisal of air emissions activities. Specific activities to be audited/appraised will be selected using a risk-based oversight schedule prioritization system. Annual ECA audit/appraisal activities will, to the extent possible, be integrated with those of the Westinghouse Hanford QA and Safety oversight organizations.

\subsubsection{Quality Compliance Assurance}

The Quality Compliance Assurance (QCA) group schedules and performs the Westinghouse Hanford QA audit activities. Audits are performed in accordance with requirements specified in WHC-CM-4-2, QR 18.0, "Audits;" QI 18.1, "Audit Programming and Scheduling;" and QI 18.4, "Integrated Audits/Appraisals" (WHC 1988). 
In accordance with QI 18.1, paragraph 4.2, QA group managers are responsible for determining internal audit needs. The Environmental Management Systems Integration (EMSI) group manager will interface with the other QA managers and other facility managers to decide on the effluent stack QA auditing needs. This will include at least one annual system audit of the stack sample collections and the analytical laboratory. It is permissible to do these as an integrated audit with the ECA group.

\subsection{QUALITY ASSURANCE}

The organizational chart for $Q A$ is referenced in Figure 3. Surveillances will be performed and controlled in accordance with WHC-CM-4-2, Quality Requirement (QR) 10.0, "Inspection," and QI 10.4, "Surveillance" (WHC 1988).

\subsubsection{Environmental Management Systems Integration}

The Environmental Management Systems Integration (EMSI) group is responsible for administering this QAPP to meet the requirements for radionuclide air emissions. This effort includes verifying that regulatory $Q A$ requirements are included and interfacing with the regulatory analysis group to ensure that regulatory updates are incorporated into the document.

The EMSI group interfaces with the Regulatory Support Organization reviewing and approving documents that define environmental regulatory quality requirements. EMSI also reviews and approves regulatory implementation documents and surveills the activities of the groups in this organization.

This group provides general direction and over sight of NESHAPS QA activities. This includes training to other $Q A$ personnel and surveillances as needed to verify that activities are controlled.

\subsubsection{Environmental Services Quality Assurance}

The ESQA group is responsible for surveillance of activities associated with control of laboratory analysis activities. This includes the following:

- Reviewing and approving laboratory analytical procedures for $Q A / q u a l i t y$ contrul ( $Q C)$ requirements

- Surveillance of laboratory activities associated with the radionuclide emissions stack monitoring

- Participating as a $Q A / Q C$ specialist in laboratory reviews and audits. 
WHC-EP-0536-1

\subsubsection{Support Quality Assurance}

The Support Quality Assurance (SQA) group is responstble for review, approval, and surveillance of activities performed by the following organtzations:

- Policy and Procedures group (see Section 6.2.1)

- Recall Systems Maintenance Engineering (see Section 6.2.6.3)

- Procedure Development/Control (see Section 6.2.6.2)

\subsubsection{Quality Assurance Standards and Requirements}

The Quality Assurance Standards And Requirements (QASR) group is responsible for the support of sitewide activities maintaining compliance with 40 CFR 61, Subpart $H$. The QASR group provides for the documentation of the WHCs Quality Assurance Program as required by 40 CFR 61.93 (b)(2)(iv) and (5) (v). The specific requirements for this program are listed in Section 4.0 of 40 CFR 61, Appendix B, Method 114, "Test Methods for Measuring Radionuclides Emissions from Stationary Sources."

\subsubsection{Facility Quality Assurance}

The Facility Quality Assurance (FQA) group consists of QA engineers from PFP Quality Assurance, FFTF Quality Assurance and Transitional Facilities Quality Assurance groups, all performing the same function. The FQA engineers are responsible for interfacing with factlity cognizant engineers in reviewing and approving facility radioactive air monitoring documentation and verifying its implementation. The activities that the FQA engineer reviews, approves, and verifies are described in Sections 6.2.1 and 6.2.6.1 of this document.

\subsubsection{Tank Waste Remediation System Quality Engineering}

The Tank Waste Remediation System (TWRS) Quality Engineering group is responsible for interfacing with facility cognizant engineers in reviewing and approving facility radioactive air monitoring documentation and verifying its implementation. The activities that the TWRS Quality engineer reviews, approves, and verifies are described in Sections 6.2.1 and 6.2.6.1 of this document.

\subsubsection{Engineering Applications Quality Assurance}

The Engineering Applications Quality Assurance group is responsible for interfacing with facility cognizant engineers in reviewing and approving facility radioactive air monitoring documentation and verifying its implementation. The activities that the EAQA engineer reviews, approves, and verifies are described in Sections 6.2.1 and 6.2.6.1 of this document. 
WHC-EP-0536-1

\subsubsection{Waste Operations Quality Assurance}

The Waste Operations Quality Assurance group is responstble for interfacing with facility cognizant engineers in reviewing and approving facility radioactive air monitoring documentation and verifying its implementation. The activities that the WOQA engineer reviews, approves, and verifies are described in Sections 6.2.1 and 6.2.6.1 of this document. 


\subsection{DOCUMENT CONTROL AND RECORDS}

Records of effluent sample analysis performed by the laboratory and used in the generation and verification of regulatory reports shall be retained by the laboratory. The effluent stack flow measurements of each facllity stack shall be retained by the facilities. These records will be controlled in accordance with WHC-CM-4-2, QR 6.0, "Document Control," and QR 17.0, "Quality Assurance Records" (WHC 1988).

\subsection{QUALITY ASSURANCE}

The QA groups perform survelllances to verify the activities noted above. The $Q A$ groups will support these audits under the direction of the QCA group.

The requirements for the control and documentation of survelllances is addressed in WHC-CM-4-2, QI 10.4, "Survelllance" (WHC 1988). This procedure specifies the requirements for survelliance preparation, distribution, scheduling, and controls.

All survelllances, with any noted deficiencies, are routed to the Environment, Safety, Quality Data (ESQD) organization, which tracks and verifies that deficiencies are addressed. The ESQD group interfaces with oversight organizations and controls their activities in accordance with WHC-CM-4-2, QI 16.6 .

\subsection{ESQ COMPLIANCE ASSURANCE}

\subsubsection{Environmental Compliance Assurance}

Section 13 of WHC-CM-7-6 (WHC 1989a), and QI 18.4 of WHC-CM-4-2 (WHC 1988) specify how ECA oversight documentation (in-process records and QA records) generated during oversight activities will be maintained and controlled.

\subsubsection{Quality Compliance Assurance}

The requirements for the control and documentation of QCA integrated audits are addressed in WHC-CM-4-2, QI 18.4, "Integrated Audits/Appraisals" (WHC 1988). This procedure specifies audit/appraisal preparation, schedule requirements, and control. 
WHC-EP-0536-1

This page intentionally left blank. 


\subsection{ORGANIZATION AND PERSONNEL QUALIFICATIONS}

All organizations and their charters are included in WHC-CM-1-2, Organization Charts and Charters (WHC 1990a). All personnel working within an organization and their job titles are included in a divisional/departmental organization chart. See Section 7.0 of this document for individual Organizational Charts.

The job classification, training, and indoctrination requirements are specifled in WHC-CM-1-3, MRP 4.22 (WHC 1990b). Each manager maintains employee records, documenting needed training completed for each job assignment, in accordance with this requirement. 
WHC-EP-0536-1

This page intentionally left blank. 
WHC-EP-0536-1

\subsection{RADIOACTIVE AIR EMISSIONS MEASUREMENT QUALITY ASSURANCE PROJECT PLANS IMPLEMENTATION}

\subsection{INTRODUCTION}

The NESHAP (EPA 1991) suggests that a Quality Assurance Project Plan (QAPJP) be prepared to the requirements of 40 CFR 61. Appendix B, Method 114, for measuring radioactive air emissions. These QAPJP requirements are addressed below.

- Each organization involved with the NESHAP program, and a description of its activities, is addressed in Section 6.2 of this document. Their responsibilities for the 40 CFR 61 Appendix B, Method 114, Section 4.0, "QA Methods," are specified on a point-by-point basis appended to this document.

- The EEM organization has issued a separate QAPJP, WHC-EP-0528, prepared in accordance with the format of QAMS-005/80 (EPA 1983). This document addresses the appropriate NESHAP requirements (see Section 6.2.5) and provides technical support to the radioactive air emissions measurement program.

- Facility organizations that are responsible for specific stacks shall prepare and maintain a NESHAP. Appendix B, Method 114. "OA Method," point-by-point implementation document (see Section 6.2.7). These are appended to this document as they are completed.

- For those organizations that work with all stacks, the implementing information is included in this document. This includes the efforts of the Health Physics and Central Support Services organizations (see Sections 6.2.1 and 6.2.6).

- The laboratory point-by-point implementation is appended to this document (see Section 6.2.2).

\subsection{ORGANIZATION AND RESPONSIBILITIES}

All organizational structure, functional responsibilities, levels of authority and lines of communication that could affect the sampling and analys is activities are addressed in section 7.0 of this document. Figures 1 through 7 provides the organizational structure and Figure 8 shows the organizational relationship: involved in the radionuclide sampling, effluent flow measurement, and analysis activities.

The ESH/QA oversight interfaces and responsibilities are addressed in Sections 3.0 and 4.0 .

The organizational responsibilities for 40 CFR 61, Appendix B, Method 114, Section 4.0, "Qual tty Assurance Methods" (EPA 1991) are described below. These descriptions define the Method 114 point-by-point information indicating each organizations area of responsibility. 
WHC-EP-0536-1

\subsubsection{Health Phystcs}

Health Physics (see Flgure 4) provides the sampling effort for the radionicilide alr emissions under the technical direction of the facility cognizant engineer. The sampling collection, tracking, and handling procedures for the effluent samples are contained in WHC-IP-0692 (WHC 1991a). Pollcies and Procedures group prepares the procedures for sample collection and the sample tracking system that are used by the Health Physics organtzation.

The sampling activities should be done in accordance with the stack monttoring and sampling requirements of 40 CFR 61. Appendix B. Method 114 (EPA 1991). The QA activities that are included in Method 114 and performed by this group are described below.

- Section 4.3.4 describes the sample collection requirements.

- Section 4.6 covers the sample tracking system for positive identification of samples from sample collection to delivery to the laboratory, as well as sample handiling and preservation procedures to maintain the integrity of samples during collection and storage.

\section{2 .2 Laboratories}

Processing and Analytical -aboratories (PAL) (see Figure 6) maintain that the radionuclide air emissions samples will be analyzed in accordance with applicable regulations. The specific radionuclides to be analyzed for are determined by Effluent Emission Monitoring (EEM) with the assistance of the facility cognizant engineer.

Laboratories shall have a QA $P l$ an and analytical procedures that meet the requirements of 40 CFR 61. Appendix B, Method 114 (EPA 1991). The QA activities Identified in Method 114 that must be addressed in laboratory QA plans are as follows:

- Calibration activities specifled by the Radionuclide Analysis Method in Method 114

- Section 4.3.5, the callbration procedures and frequency of callibration required for the analytical procedures used by the laboratory

- Section 4.5, a quality control program to evaluate and track the quality of emissions measurement data

- Section 4.6, a sample tracking system to provide for positive identification of samples and data through all phases of sample recelpt, analysis, and reporting

- Section 4.6, a sample control system to maintain the integrity of samples during storage and analysis. 


\subsubsection{Regulatory Analysis}

Regulatory Analysis (RA) within the Restoration and Remediation Division (see Figure 5) is responsible for the WHC-CM-7-5, Environmental Compl tance manual which establishes the environmental compliance requirements and guidelines for WHC in conjunction with applicable DOE Orders and federal, state, and local laws and regulations. Regulatory Analysis also provides guldance on the interpretation of regulations and interfaces with the regulatory agencies to resolve regulatory issues.

\subsubsection{Regulatory Program Integration}

Regulatory Program Integration (RPI) within the Restoration and Remediation Division (see Figure 5) is responstble for reviewing WHC generated documents affecting the design, construction, and operation of stack monitoring systems subject to the requirements of 40 CFR 61. Such documents include, but are not 1 imited to, procurement specifications, design drawings, facility effluent monitoring $p$ lans, and engineering change notices. RPI reviews this documentation against the monitoring requirements of 40 CFR 61 with the goal of ensuring sitewide compliance.

\subsubsection{Effluent Emission Monitoring}

The Effluent Emissions Monitoring (EEM) group (see Figure 5), within the Restoration and Remediation (RR) organization, has the following responsibilities:

- Provide technical support for radioactive alr emissions sampling and monitoring

- Provide technical requirements of radioactive atr sample analysis; sampling schedule, list of specific radionuclides to be analyzed, and lower limits of detection

- Compile radioactive air sampling data and flow rates to prepare regulatory reports

- Verify sample analysis parameters received from the laboratory.

- Document records of radioactive air emissions in annual reports cleared for public access.

The QAPJP WHC-EP-0528 addresses the following sections of 40 CFR 61 , Append IX B, Method 114 (EPA 1991):

- Section 4.3.1, provide identification numbers for sample locations

- Section 4.3.5, specify the analysis that is to be performed for each stack

- Section 4.4, provide the data quality objectives for the sampling and analysis activities. 


\subsubsection{Contral Support Services}

The effluent flow measurement activities are performed by the central Support Services group (see Figure 7) under the control of the facility cognizant engineer.

The QA activities from Method 114 (EPA 1991) that are performed by the organizations described below, through Central support Services, are described in the paragraphs that follow.

6.2.6.1 Ventilation and Balance. The effluent flow measurements are performed by this group in accordance with procedures that are included in a Job Control System (JCS) (see WHC-CM-8-8 [WHC 1989b]) work package. These procedures are currently being updated to meet the requirements of 40 CFR 61, Appendix B, Method 114, (EPA 1991) Section 4.3.7. The facility cognizant engineer is responsible for the JCS work package that is transmitted to the ventilation and balance organization.

The data collected from this activity are provided to the facility cognizant engineer who is responsible for verifying and transmitting this information to the EEM group.

6.2.6.2 Procedure Development and Control. The procedures used for the effluent measurements and facility equipment calibrations are prepared by this group in accordance with the requirements of 40 CFR 61. Appendix B, Method 114, (EPA 1991), Section 4.3.7. Some of these procedures are generic, with the piant-specific information being included in the JCS package.

The development and control of these procedures are addressed in WHC-CM-8-10, Section 06-03 (WHC 1990C).

6.2.6.3 Recall Systems Maintenance Engineering. The scheduling of calibration for the continuous stack flow measurement equipment is controlled by this group in accordance with the requirements of 40 CFR 61 , Appendix B, Method 114, (EPA 1991), Section 4.3.7, This scheduling information is forwarded to the facility planner/scheduler who prepares the JCS work package under the direction of the facility cognizant engineer. This work package is required for the maintenance forces to perform the calibration(s). The completed calibration information is returned to Recall systems Maintenance Engineering for tracking purposes.

The control of these calibration scheduling and tracking activities is addressed in WHC-CM-8-2, Section 2.0 (WHC 1991b).

\subsubsection{Facilities}

The facility cognizant engineers (see Figure 6) are responsible for defining how the stack sampling, analysis, and effluent flow measurement requirements are implemented. The facility cognizant engineer prepares the 
radionuclide stack point-by-point implementation that addresses the sections of 40 CFR 61, Appendix B, Method 114 (EPA 1991), described below.

- Section 4.2 describes the administrative controls that are used at the facility to ensure a prompt response in the event that emission levels increase because of unplanned operations.

- Section 4.3.1 specifies the number of sample points and the rationale for sample site selections.

- Section 4.3.2 describes sampling probes and representativeness of samples.

- Section 4.3.4 identifies the sampling procedure(s) to be used and sampling frequency.

- Section 4.3.6 describes the sample flow rate measurement systems or procedures, including calibration procedures and frequency of caltibration.

- Section 4.3.7 describes the effluent flow rate measurement system, including frequency of measurements. The facility cognizant engineer is responsible for verifying these flow rates and transmitting the information to the EEM organization.

\subsubsection{Other Support Contractors}

Procurement of the services of other subcontractors to support radionuclive effluent activities addressed in this QAPP may be initiated by WHC. Such services shall be in compliance with standard WHC procurement procedures requirements. All work shall be performed in accordance with approved QA plans and/or procedures, subject to the controls of WHC-CM-4-2, QR 4.0, "Procurement Document Control," and QR 7.0, "Control of Purchased Items and Services," (WHC 1988). 
WHC-EP-0536-1

This page intentionally left blank. 
WHC-EP-0536-1

\subsection{ORGANIZATIONAL CHARTS AND FIGURES}

The following eight charts show in more detall how the pertinent organizations fit together within the WHC structure. Organizational codes are included as references.

The President of WHC has an organization code of 01000 and all subsequent sequences are manager levels from Level 1 down to Level 4 . The Level 1 managers are D0000, Level 2 are DDO00, Level 3 are DDDOO and Level 4 are DDDDO. The $D$ represented within an organizational code signifies a digit or an alpha character.

Figure 8, Emission Sampling and Analytical Implementation is a flow chart representing the different groups involved with the process of sample and data handling. 


\section{WHC-EP-0536-1}

This page intentionally left blank. 
WHC-EP-0536-1

Figure 1. Organizational Chart for WHC Sentor Management.

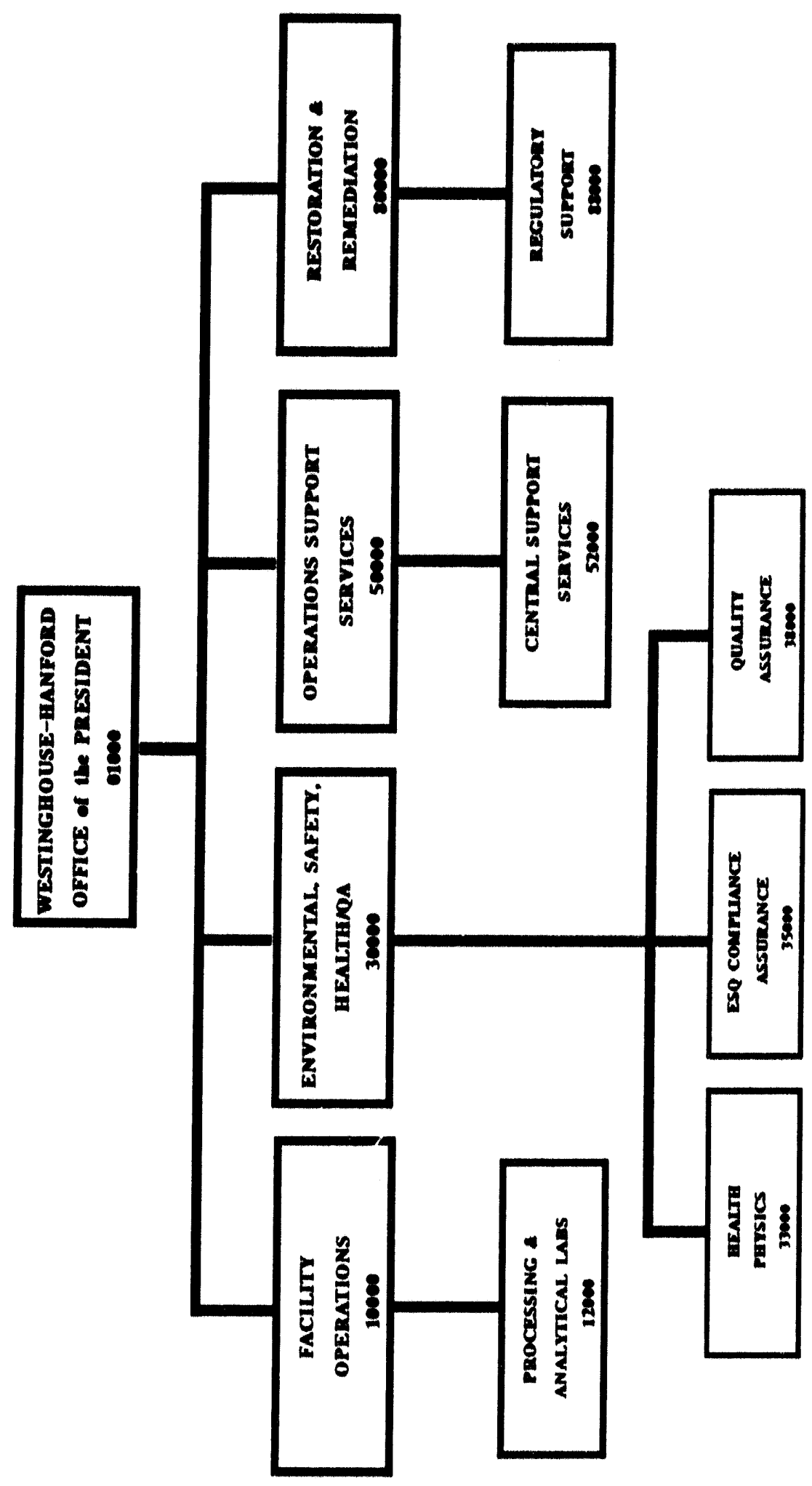


WHC-EP-0536-1

This page intentionally left blank. 
WHC-EP-0536-1

Figure 2. Organizational Chart for ESQ Compliance Assurance.

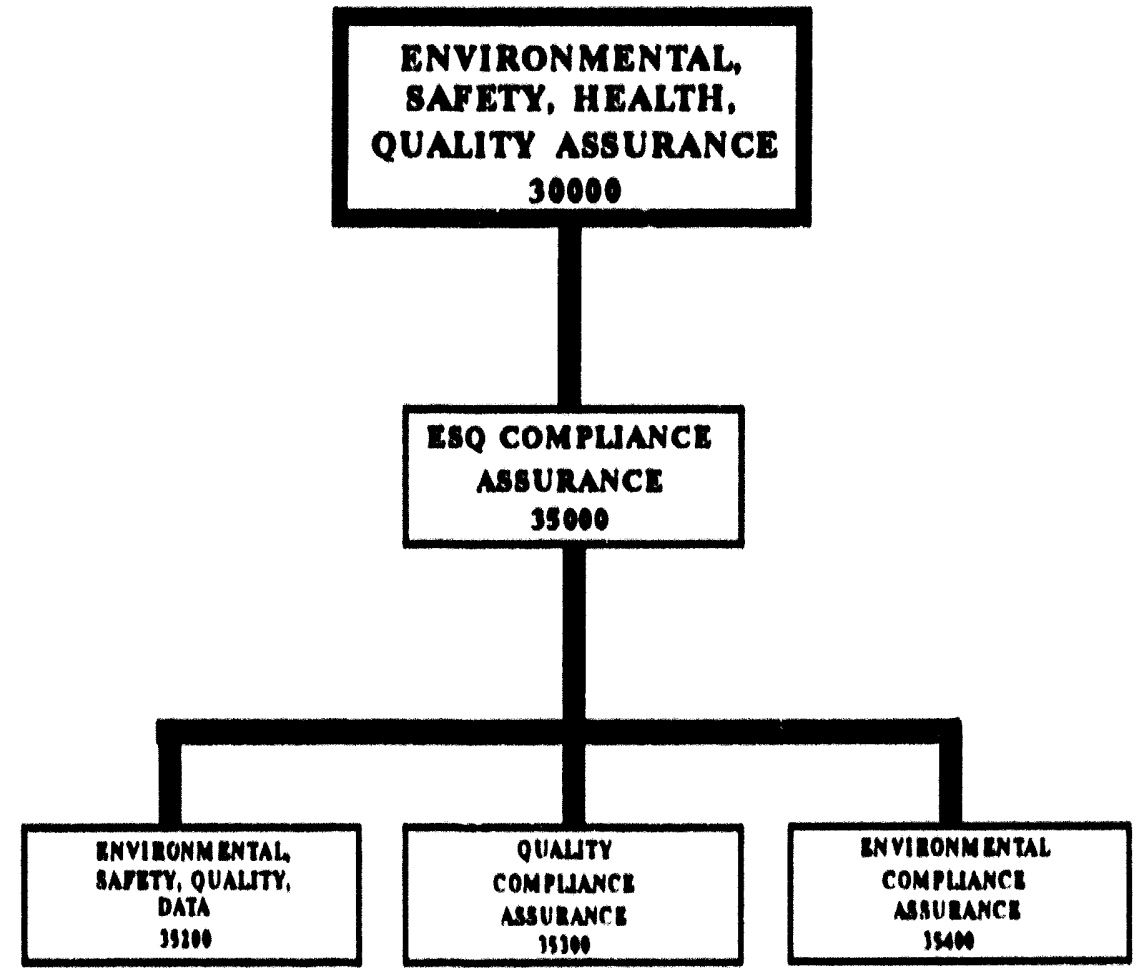


WHC-EP-0536-1

This page intentionally left blank. 
WHC-EP-0536-1

Figure 3. Organizational Chart for Quality Assurance.

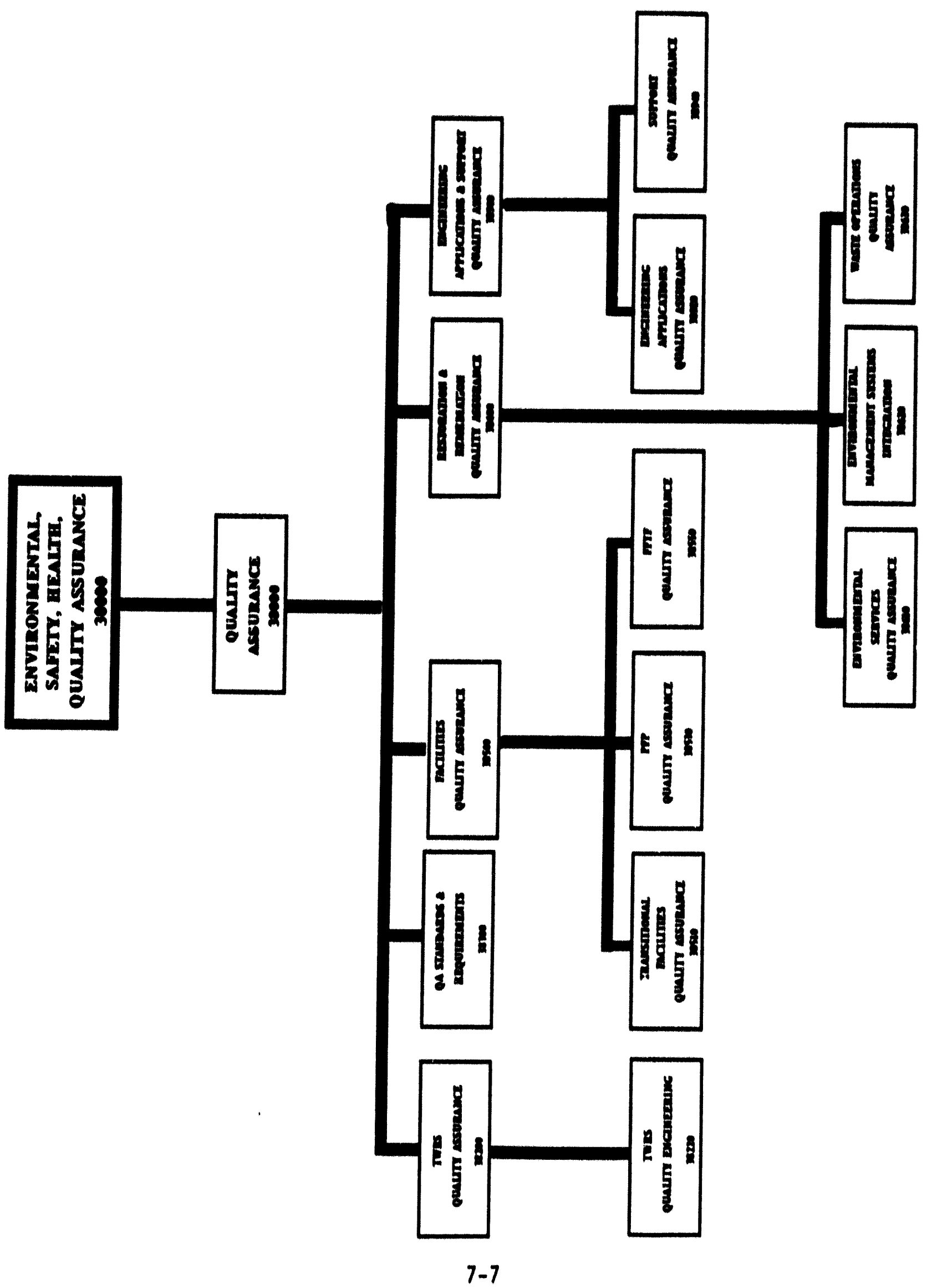


WHC-EP-0536-1

This page intentionally left blank. 
WHC-EP-0536-1

Figure 4. Organizational Chart for Health Physics.

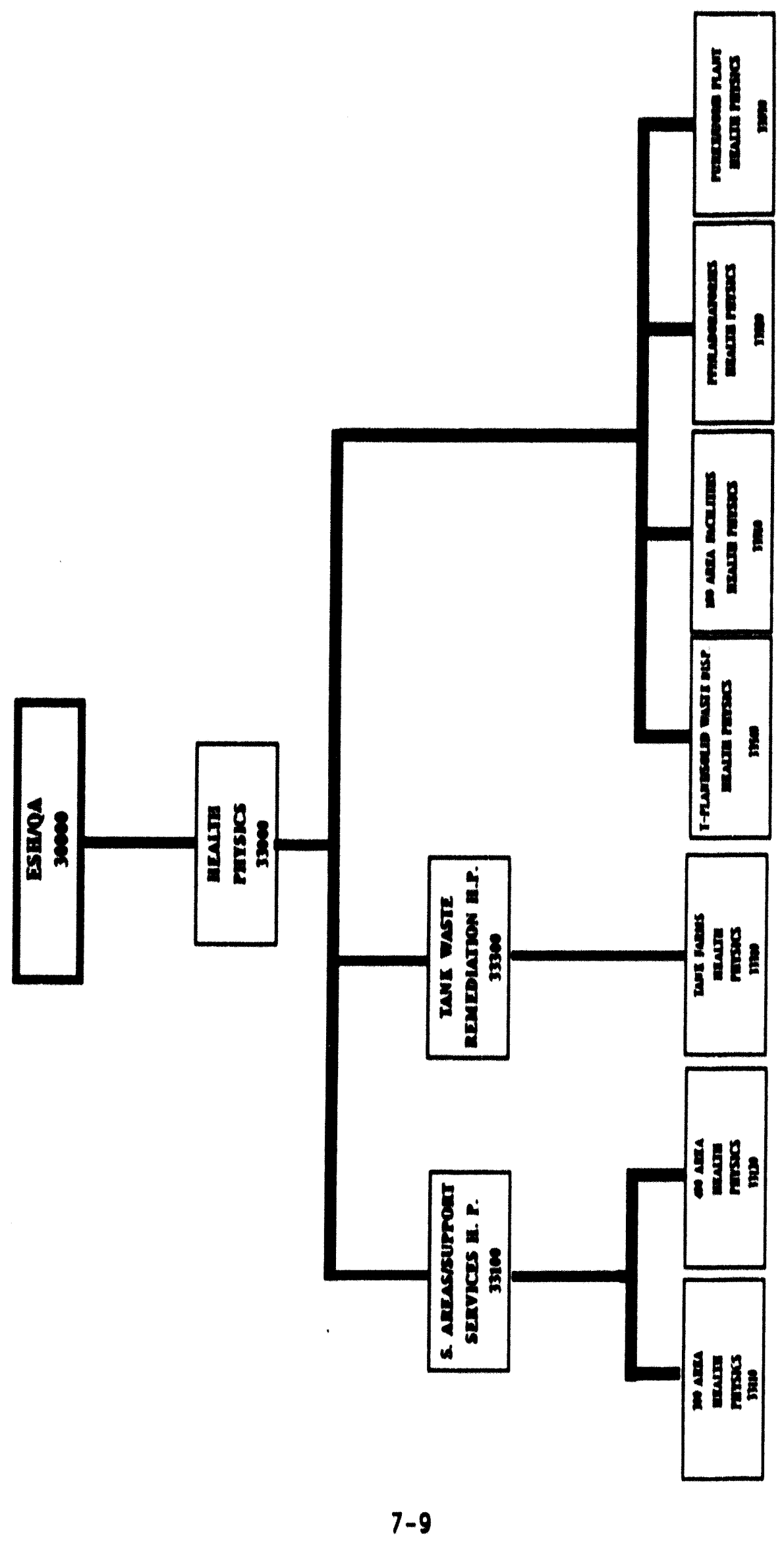


WHC-EP-0536-1

This page intentronally left blank. 
WHC-EP-0536-1

Figure 5. Organizational Chart for Restoration \& Remediation.

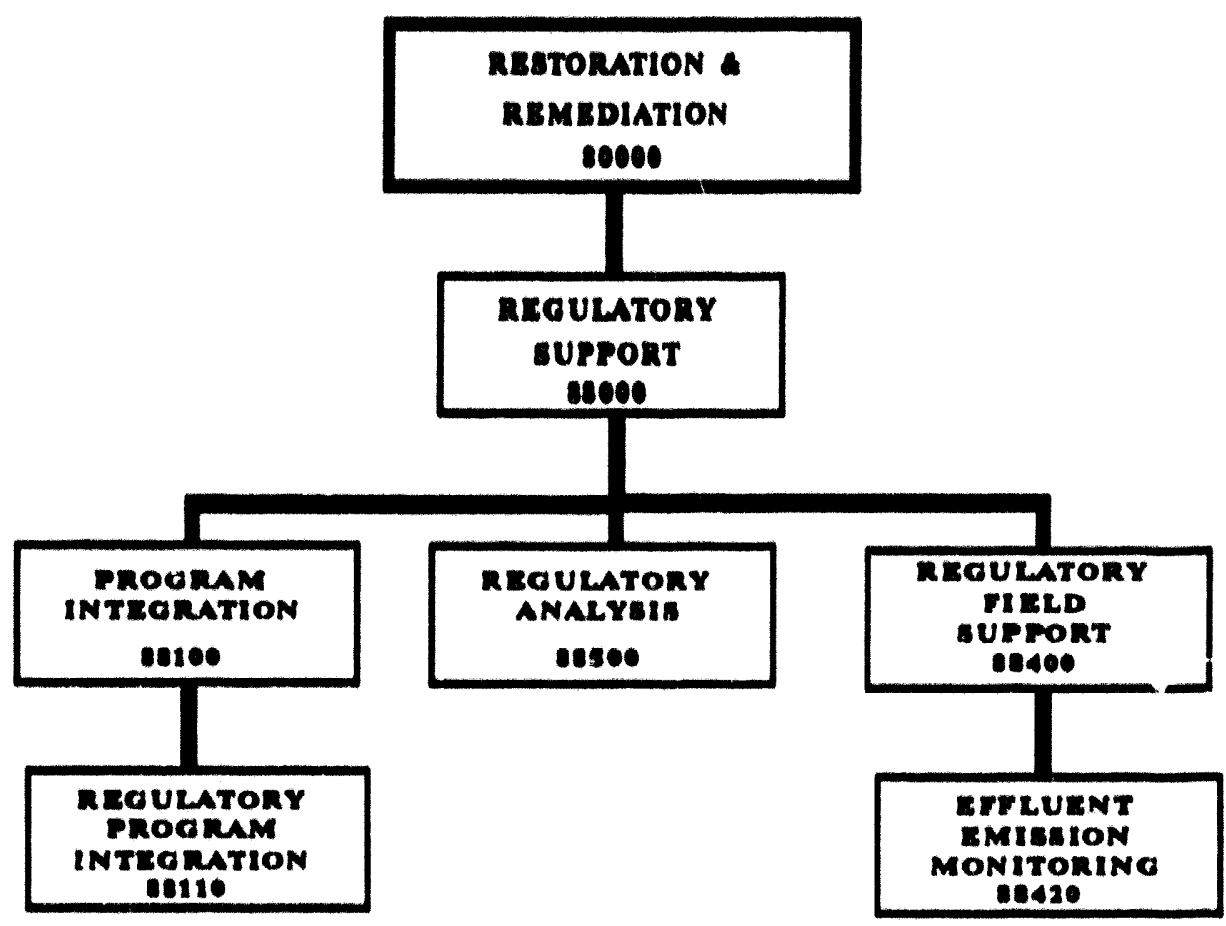


WHC-EP-0536-1

This page intentionally left blank. 
WHC-EP-0536-1

Figure 6. Organizational Chart for Facility Operations.

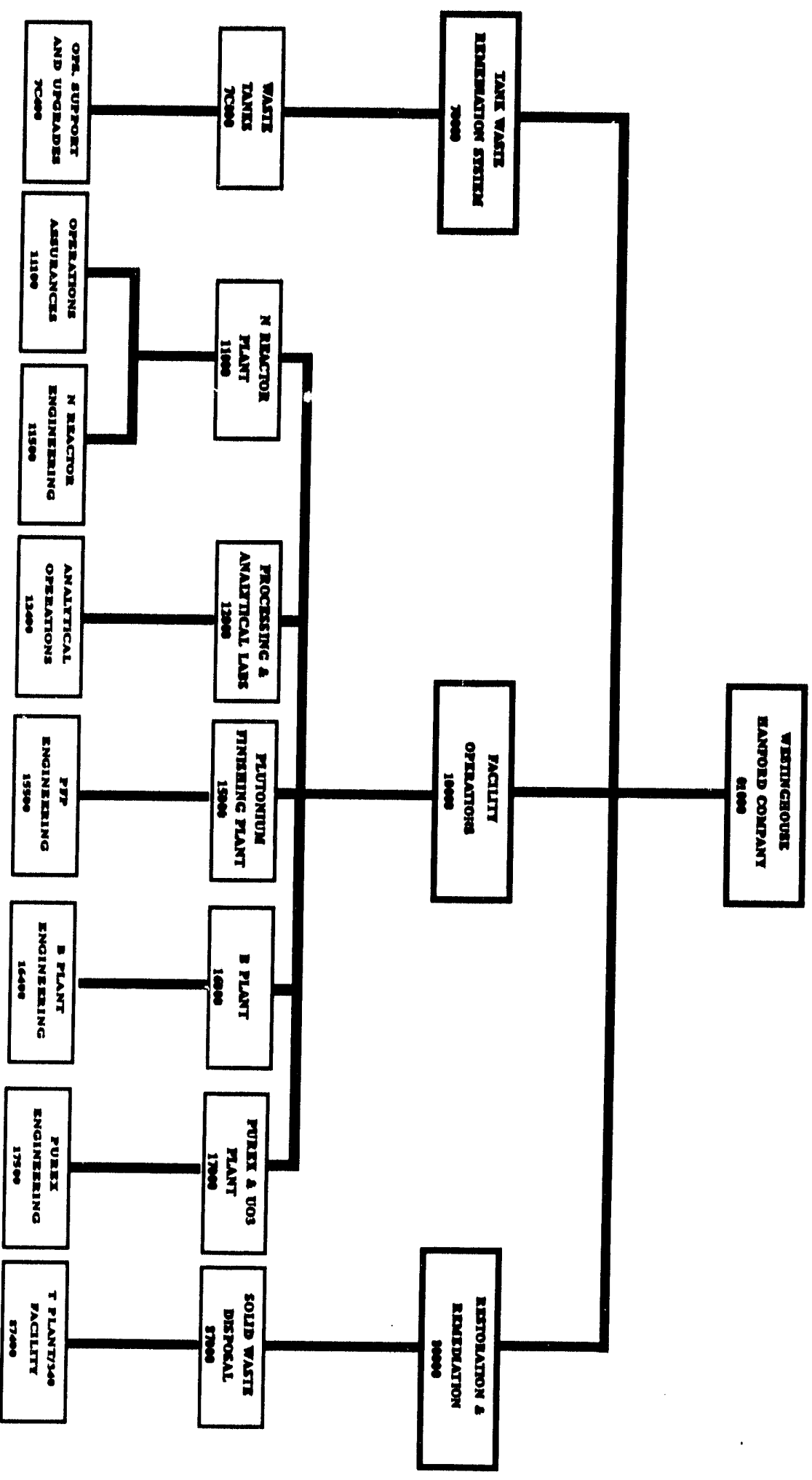




\section{WHC-EP-0536-1}

This page intentionally left blank. 
WHC-EP-0536-1

Figure 7. Organizational Chart for Operations Support Services.

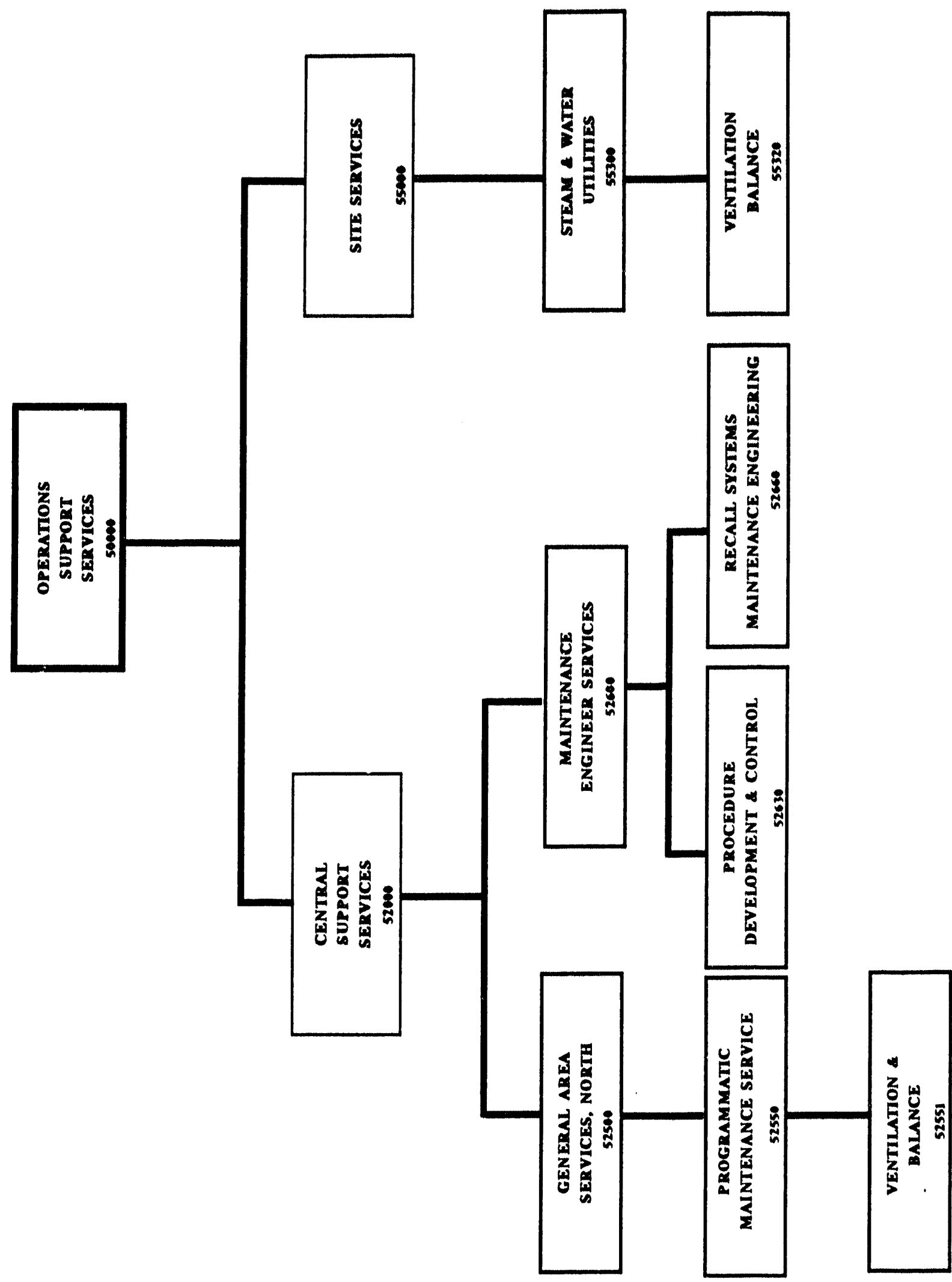


WHC-EP-0536-1

This page intentionally left blank. 
WHC-EP-0536-1

Figure 8. Emission Sampling and Analytical Implementation.

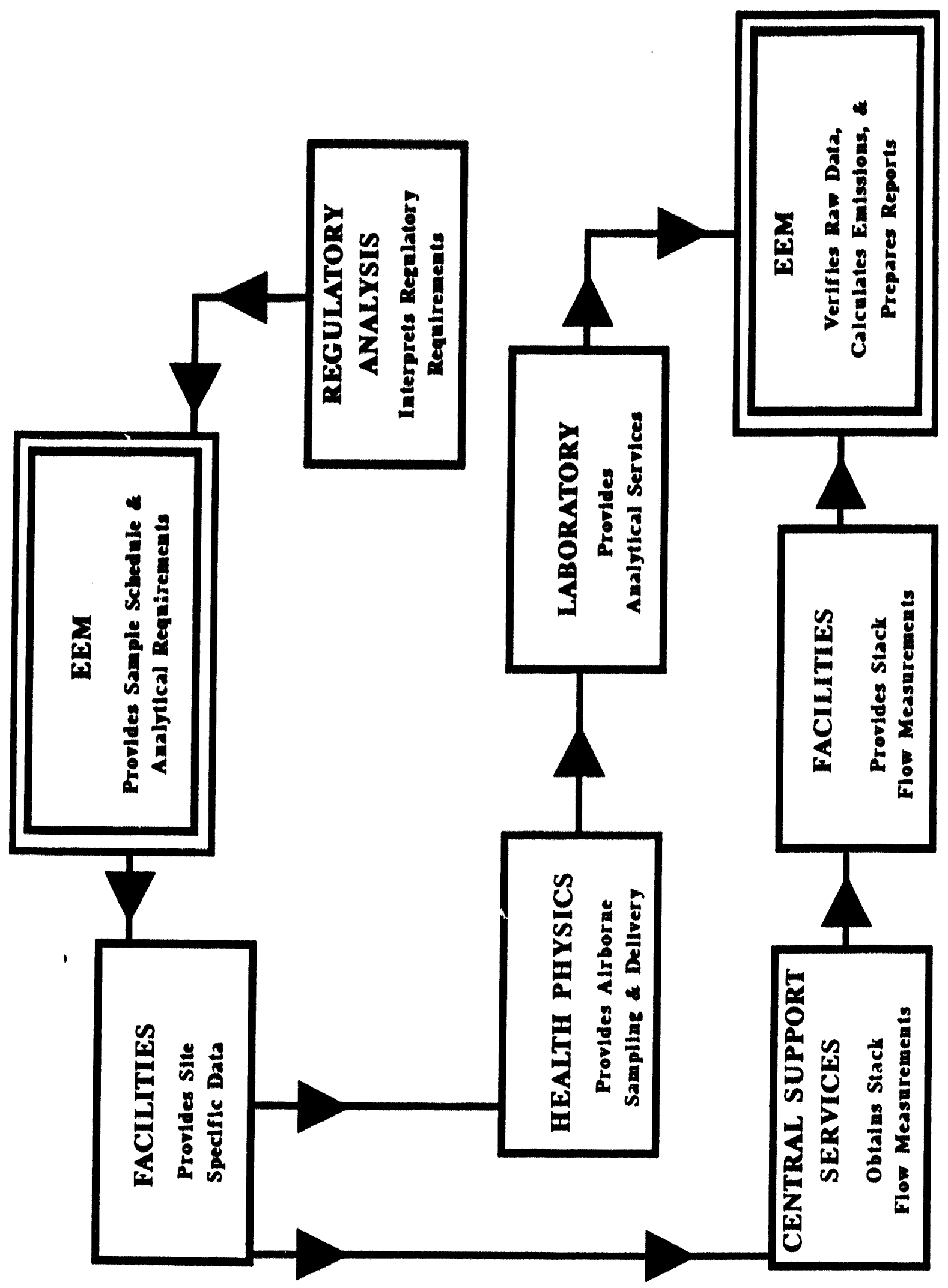


WHC-EP-0536-1

This page intentionally left blank. 


\subsection{PERFORMANCE AND SYSTEM AUDITS}

Audits shall be performed to verify the quality of operation of one or more elements of the total measurement system. Audits will be of the two types below.

- Performance audits, in which quantitative data are independently obtained for comparison with data routinely obtained by the measurement system.

- System audits, involving a qualitative onsite evaluation of laboratories (or other organizational elements of the measurement system) for compliance with established QA program and procedure requirements. This also includes audits of individual facility sampling programs against those requirements of this QAPP and factlity QAPJPs.

A performance audit system needs to be established whereby performance evaluation samples are submitted to the laboratortes.

System audits are currently being performed by the Environmental Compllance Assurance and the Quality Compliance Assurance Organizations. (See Sections 4.2 and 4.2 .1 of this document). 
WHC-EP-0536-1

This page intentionally left blank. 
WHC-EP-0536-1

\subsection{CORRECTIVE ACTION}

Corrective action requests required as a result of survelllance or audit activity shall be documented and disposittoned as required by WHC-CM-4-2,

Q1 10.4. "Surva11lance;" QR 15.0, "Control of Nonconforming Itams;" QI 15.1, "Nonconforming Item Reporting;" and/or QR 16.0 "Corrective Action" (WHC 1988). 
WHC-EP-0536-1

This page intentionally left blank. 


\subsection{QUALITY ASSURANCE REPORTS}

As stated in Sections 3.0 and 8.0, radionuclide effluent monitoring shall be regularly assessed by survelll ance and auditing processes. Survelllance, nonconformance, audit, and corrective action documentation shall be considered $Q A$ records and shall be documented and dispositfoned as stated in Section 4.0. Records management requirements applicable to subcontractors or participant contractors shall be defined in applicable procurement documents or work orders as noted in Section 6.2.8. 
WHC-EP-0536-1

This page intentionally left blank. 
WHC-EP-0536-1

\subsection{REFERENCES}

Ecology, EPA, and DOE, 1990, Hanford Federal Facility Agreement and Consent Order, Vol. 2, "Calendar Year 1990 Annual Update, "Washington State Department of Ecology, U.S. Environmental Protection Agency, and U.S. Department of Energy, Olympia, Washington.

Ecology, EPA, and DOE, 1991, Hanford Federal Facillty Agreement and Consent Order, Vol. 1, "Second Amendment September 1991, "Washington State Department of Ecology, U.S. Environmental Protection Agency, and U.S. Department of Energy, Olympla, Washington.

EPA, 1983, Guidelines and Specifications for Preparation of Quallty Assurance Program Plans, QAMS 004/80, U.S. Environmental Protection Agency, Washington, D.C.

EPA, 1991, "National Emission Standards for Hazardous Atr Pollutants," Title 40, Code of Federal Regulations, Part 61, U.S. Environmental Protection Agency, Washington, D.C.

WHC, 1988, Quality Assurance Manual, WHC-CM-4-2, Westinghouse Hanford Company, Richland, Washington.

WHC, 1989a, Environmental Compliance Verification Manual, WHC-CM-7-6, Westinghouse Hanford Company, Richland, Washington.

WHC, 1989b, Job Control System Manual, WHC-CM-8-8, Westinghouse Hanford Company, Richland, Washington.

WHC, 1990a, Organization Charts and Charters, WHC-CM-1-2, Westinghouse Hanford Company, Richland, Washington.

WHC, 1990b, Management Requirements and Procedures, WHC-CM-1-3, Westinghouse Hanford Company, Richland, Washington.

WHC, 1990c, Operations Support Services Standard Practices, WHC-CM-8-10, Westinghouse Hanford Company, Richland, Washington.

WHC, 1991a, Health Physics Procedures, WHC-IP-0692, Westinghouse Hanford Company, Richland, Washington.

WHC, 1991b, 200 Area Support Services, WHC-CM-8-2, West inghouse Hanford Company, Richland, Washington. 
WHC-EP-0536-1

This page intentionally left blank. 
WHC-EP-0536-1

APPENDICES TO THE QUALITY ASSURANCE PROGRAM PLAN 
WHC-EP-0536-1

This page intentionally left blank.

APP- $i j$ 


\section{INTRODUCTION TO APPENDICES}

These appendices supply information regarding a point-by-point comparison with Title 40, Code of Federal Regulations (CFR), Part 61*, Appendix B, Method 114, for the Hanford Site air emissions involving stacks known to have the potential to exceed 40 CFR 61, Subpart H, limits. Please note that Appendices $A$ through $F$ are intended to supply the information for which each facility has responsibility, and that Appendices $G$ and $H$ are intended to supply the information for which the analytical laboratories have responsibility. Specifically, Appendix G includes information for Hanford Site 200 Area stack analyses, and Appendix $H$ includes information for Hanford Site 300 Area stack analyses.

*EPA, 1992, "National Emission Standards for Hazardous Air Pollutants," Title 40, Code of Federal Regulations, Part 61, U.S. Environmental Protection Agency, Washington, D.C. 
WHC-EP-0536-1

This page intentionally left blank. 
WHC-EP-0536-1

\section{APPENDIX A}

METHOD 114 COMPARISON FOR STACK 291-A-1

Dan Johnson/Jahan Lohrasbi 
WHC-EP-0536-1

This page intentionally left blank. 


\section{APPENDIX A}

\section{METHOD 114 COMPARISON FOR STACK 291-A-1}

2.1 Radlonuclides as Particulates. The extracted effluent etreen is passed through a fllter medie to remove the particulates. The fllter must have high efflelency for removal of sub-micron particles. the guidance in ANSi N13.1-1969 shall be followed in using filter madia to collect particulates (incorporated by reference-see $\$ 61.18$ ).

Particulates are collected on a sample fllter made of Gelman Versapor 3000*. According to the manufacturer, this fllter medium has an efficiency of $95.8 \%$ for $0.3 \mathrm{\mu m}$ particles.

2.2.1 The Radlonuclide Tritium (H-3). Irltiun in the form of water vapor la collected from the extracted effluent semple by sorption, condensetion or dissolution techniques. Appropriate collectors may include sillica gel, molecular ieves, and ethylene glycol or water bubblers.

Tritium in the gaseous form may be measured directly in the semple strean using Method B.1, collected as a gas semple or may be oxidized using a metal catalyet to tritiated water and collected as described above.

No irradiated fuel has been introduced into the Plutonium-Uranfum Extraction (PUREX) Plant for several years. No dissolutions have been performed since late 1989. Gaseous sampling systems have shown that the levels of ${ }^{3} H$ and ${ }^{14} C$ have fallen to leveis at or below the analytical detection 1 imit, which were well below environmental release and monitoring limits. Consequently, sampling for these nuclides is no longer required or performed.

2.2.2 Radionuclides of lodine. Iodine is collected from an extracted semple by sorption or dissolution techniquen. Appropriate collector may include charcoal, impregnated charcoal, metal 200 lite and caustic solutions.

No irradiated fuel has been introduced into the PUREX Plant for several years. No dissolutions have been performed since late 1989. Furthermore, concentrations of radiolodine in any fuel avallable for processing have decayed to such a low level that there is no longer any requirement to monitor for lodine. Nevertheless, sampling for lodine continues. Because it is not required, this sampling may be discontinued without notice.

After flowing through the Gelman Versapor 3000 filter, the gas sample flows through two silver zeolite cartridges to capture iodine.

2.2.3 Radionuclides of Argon, Krypton and Xenon. Radionuclides of these elements are either measured directly by an in-line or off-line monitor, or are collected from the extracted sample by low temperature sorption techniques, Appropriate sorbers may include charcoal or metal zeollte.

*Trademark of Gelman Sciences, Inc. 
No irradiated fuel has been introduced into the PUREX Plant for several years. No dissolutions have been performed since late 1989. Gaseous sampling systems had shown that the levels of ${ }^{3} \mathrm{H}$ and ${ }^{14} \mathrm{C}$ had fallen to levels at or below the analytical detection 1 imit, which were well below environmental release and monitoring 1 imits. Consequentiy, sampling for these nuclides is no longer requited or performed. The release of other radioactive gases decreased more rapldiy than for these nuclides. Consequently, there is no need for gaseous nuclide sampling.

2.2.4 Radlonuclldes of Oxygen, Carbon, Witrogen and Radon. Radionucllase of these el aments are mesesured directly using an in-line or off.line monitor. Redionuclides of cerbon in the form of carbon dioxide may be collected by diseolution in caustic solutions.

There is no longer need for gaseous radionuclide sampling (see Sections 2.2.1 through 2.2.3 above. 


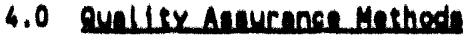

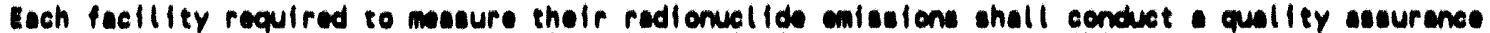
progrem in conjunction with the redionuclide emiacion meseuremente. This progrem shall esoure that the emiselan meseurements are representative, and ore of known preciston and eccurocy and shall in. clude adninistrative controls to assure prompt response then eniselon mesurements Indicate unexpectedly large emlestons. The progran thall conalet of aysten of policies, organlzotional responsibliltles, written procedures, data quallity apaclfications, audita, correctlve ections and reports. Thls qualley eseurance progrem shall include the following progrem elementes

4.1 Documentation Identlfying the organlzetlonal structure, functional responsibllitles, levale of authority and lines of commenications for all setivities related to the emiselons meseurcment progrem.

See section 6.2 of the main part of this document for the organizational structure.

4.2. Prescrlbed adminlatrative controls to ensure prompt response in the event that emiselon levels increase due to unplanned operations.

WHC-CM-4-12 (WHC 1992a), Section 1.14, REV 1, ALARM RESPONSE AND MANAGEMENT. This practice establishes requirements and provides guldance for responding to alarms that are the responsiblitity of Health Physics (HP).

This practice does not apply to alarms intentionally activated according to approved procedures, (e.g., functlonal test, source test). Faclitity specific procedures or desk instructions based on those procedures may be provided by the Area HP Managers to address alarm systems specific to each facility.

WHC-CM-4-12, Section 2.1, REV 0, RADIOLOGICAL PROBLEM REPORTING PROGRAM. The purpose of the Radiological Problem Report (RPR) program is to provide a documented record of observed radiological problems, a mechanism for reporting these problems to management for action, a capability to track and monitor the progress of the planned corrective actions, and a database for assessing trends in radiological program performance and needed actions.

WHC-CM-4-12, Section 12.1, REV I EMERGENCY RESPONSE. An EMERGENCY is a sudden unexpected event requiring immediate response to mitlgate impacts to people, property, or the environment. When radioactive material is involved, Health Physics (HP) plays a major role in evaluating, controlling, and recovering from the event. To be able to perform this function HP personnel receive training to respond to a variety of emergency situations. The HP procedures are written to provide guidelines to respond to emergencles. Together, the training and written procedure detall the HP Emergency Response Program.

Emergency Response. The HP personnel are, in many situations, the first to respond to a radiological emergency. The abllity to assess and evaluate the situation and take immediate steps to minimize the effects of the event is crucial for controlling the emergency. The HP personnel must use their training and expertence to make good decisions during the initial response to an emergency. 
An emergency response may be inttlated by personnel observing the ovent, alarms, the Patrol Operation Center, or the Emergency Control Center(s) once they are manned. For a planned response, HP personnel shall be in teams of at least two. Out of nocessity (e.g., backshtft response), one member could be an Operations person or other emergency service person such as fire or patrol. A rapld response is requtred; however, no undue risks should be taken nor should employee personnel safety be compromised. The type of emergency determines the level of planning for HP response. For example, a continuous afr monitor (CAM) alarm or a small radioactive splli requires little planning for the initlal response. However, when an emergency causes a facility ovacuation, proplanning (e.p.: stay time, entry route, otc.) and approval of the Building/faclifty Emergency Director is necessary for a re-entry.

Although HP personnel rospond to an emergency using basic guideilnes, an area/facillty may have spectflc procedures that have prlority over these guidelines.

WHC-IP-0692 (WHC 19912), Section 12.1.2.3, REV 2, EFFLUENT EXHAUST CAN ALARM RESPONSE. This procedure estabilishos the standard method of handling samples from, and response to alarms at, Effluent Exhaust CAM systems.

WHC-IP-0692, Soction 12.1.2.4, REV 0, PUREX MAIN STACK (291-A-1) ALARM RESPONSE. This procedure establishes the mothod of response to alarms occurring on the Moving Filter Radioactive Aerosol Monftor (MFRAM), on the Continuous Particulate Release Monitor (CPRM), to alarms on the CPRM or MFRAM lodine monitors, or to high-activity levels detected on the Effluent Release Record Sample.

WHC-IP-0692, Section 12.1.6, REV 2, STACK EFFLUENT RELEASE RESPONSE. This procedure establishes guidelines for responding to a potential or actual release of radloactive matertal through exhaust stacks.

WHC-IP-0692, Section 12.2.1, REV 2, EMERGENCY RESPONSE AIR SAMPLING. This procedure establishes the instruction and guidelines for air sampling in an emergency situation.

WHC-IP-0692, Section 12.2.3, REV 0, HEALTH PHYSICS EMERGENCY RESPONSE TEAM. This procedure provides the organizational structure of, the instructions for, and the responsibllities of the HP Emergency Response Team and the Radiation Protection Technologist (RPT) Fleld Survey Teams.

WHC-IP-0692, Section 12.2.4, REV 2, EMERGENCY RADIOACTIVE PLUME TRACKING. This procedure establishes the instruction to track a plume created from a radioactive material release to the environment.

WHC-IP-0692, Section 12.2.6, REV 0, GENERAL GUIDELINES FOR EMERGENCY RESPONSE. This procedure provides general guldelines to handle emergency situations. 
WHC-IP-0263-202A (WHC 1992b), Westinghouse Hanford Company Emergency Plan for PUREX Facllity. Thls document provides instructions for many types of emergenctes, Including excesstve releases of radioactivity via the stacks.

WHC-CM-5-9 (WHC 1992C), Section 2.3, REV 1, PUREX/UO, Plant Occurrence Categorlzation, Notfflcation, and Reporting. This procedure provides instructions for notfflcation and reporting of speciflc ovents including environmental roleases and related events.

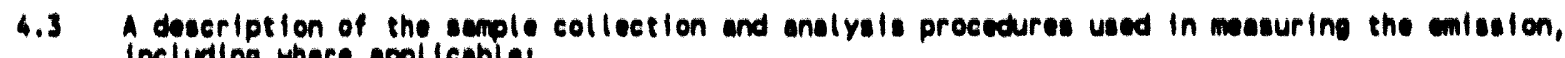
including whare appllables

4.3.1 Identifleation of sempling eltes and number of sampling pointe, including the rotional for it te solection.

The 291-A-1 stack is 7 feot in diameter. The record sampling site is a vertical section of the stack, at a halght of 60 feet abovegrade. There are total of three sampling sites and six sampling probes.

The elevations of the sample ports are 60, 74, and 88 foet abovegrade, which is tho location of the last major flow disturbance in the stack. The sample ports are, therefore, approximately 8.6, 10.6, and 12.6 diameters downstream of the last major disturbance.

The stack is 200 leet, or 28.6 dlameters, tall. The sample ports are, therefore, approximately 20, 18, and 16 diameters upstream of the next major flow disturbance.

The sites were chosen to provide representative sampling of the effluent and to comply with ANSI N13.1-1969 (ANSI 1969). The lowest sample port was chosen as the location of the record sample probe to minimize the length of sample line in accordance with ANSI N13.1-1969. These sample points also meet the criterle of 40 CFR 60, Appendix A, Method I (EPA 1992).

4.3.2 A description of the sempling probes and representativenese of the semples.

The sampling probes are "rakes," that is, multiport probes. The rakes are paired, 1.e., there are two rakes at each sample location. With the exception of the particulate record sample, each rake has six inlet ports consisting of $3 / 8 \mathrm{in.} 00$ by $0.035 \mathrm{in}$. wall 316 stainless steel tubing. At the inlet, each port is tapered to a knife edge with a 15-degree angle. At the 74-foot level, the inlet ports have a $2-i n$. vertfcal section followed by a $2-1 n$. radius bend leading into the rake. (The backup record sample is collected from a rake at the 74-foot level.) At the 60-foot and 88-foot levels, the inlet ports have a $1-7 / 8-i n$. vertical section followed by a $1-7 / 8-i n$. radius bend.

The six-point sample rakes collect samples from the approximate centers of equal-area annuli in the stack, alternating botween the near and far sides of the annull. (For an annulus, the "center" is halfway between the inner and outer radil of an annulus.) The table 
WHC-EP-0536-1

below compares the actual and Ideal locations of the inlet ports, and also ifsts the difference in inches. The postetons are measured from the center of the stack in the direction away from the ilner penotration. The tolerance on the actual dimenstons $18 \pm 0.1 \mathrm{in}$.

\begin{tabular}{|c|c|c|}
\hline $\begin{array}{c}\text { Actual } \\
\text { (feot) }\end{array}$ & $\begin{array}{c}\text { Ideal } \\
\text { (feet) }\end{array}$ & $\begin{array}{c}\text { Difforance } \\
\text { (1nches) }\end{array}$ \\
\hline-3.33333 & -3.34752 & 0.170289 \\
\hline-2.66666 & -2.66630 & 0.004329 \\
\hline-1.66666 & -1.72479 & 0.697569 \\
\hline 0 & 0 & 0 \\
\hline 2.26 & 2.247799 & 0.026401 \\
\hline 3 & 3.026393 & 0.316717 \\
\hline
\end{tabular}

The rake that currently collects the partfculate record samplo has 16 inlots, consisting of 304 stainiess steel tubing. At the inlot, each port is tapered to a knife edge with a 16-degree angle. The inlet ports have a $2-1 \mathrm{n}$. verttcal section followed by $2-1 \mathrm{n}$. radtus bend leading into the rake at a 46-degree angle. The outer two ports are made of $3 / 8 \mathrm{in} .00,0.065-1 \mathrm{n}$. wall tube. The next six ports are made of $1 / 4 \mathrm{in} .00,0.028-\mathrm{in}$. wall tube. The inner elght ports are made of $1 / 4$ in. 00, 0.035-in. wall tube. The inlet ports are arranged symmotricaily and approximately centered over equal-area semi-annull. The table compares the actual and Ideal locations of the iniot ports, and also lists the difference. The positions are measured from the center of the stack. The tolerance on the actual dimenstons $1 \mathrm{~s} \pm 0.1 \mathrm{in}$.

\begin{tabular}{|c|c|c|}
\hline $\begin{array}{c}\text { Actual } \\
\text { (feet) }\end{array}$ & $\begin{array}{c}\text { Ideal } \\
\text { (feet) }\end{array}$ & $\begin{array}{c}\text { D1fference } \\
\text { (1nches) }\end{array}$ \\
\hline 0.6167 & 0.618718 & 0.024621 \\
\hline 1.5000 & 1.493718 & 0.075378 \\
\hline 1.9600 & 1.946652 & 0.040178 \\
\hline 2.3083 & 2.309088 & 0.009063 \\
\hline 2.6250 & 2.620933 & 0.048799 \\
\hline 2.9000 & 2.899040 & 0.011508 \\
\hline 3.1500 & 3.152519 & 0.030234 \\
\hline 3.3833 & 3.386975 & 0.043701 \\
\hline
\end{tabular}

The use of an 1sokinetic 16-point probe located more than 8 duct dlameters downstream of the last major flow disturbance ensures representative sampling.

4.3.3 A deseription of uny continuous monltoring syatems used to masure emiselons, including the sensitivity of the eyetem, callbration procedures and frequency of callbratlor.

Not applicable--emissions are not monitored continuousiy for compl tance demonstration. 
WHC-EP-0536-1

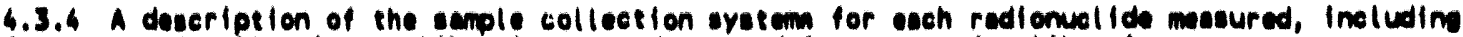
frequency of collection, callibration procectures and frequency of call fbration.

The sample is continuousiy removed from the effluent stream via the rake described in section 4.3.2. The sample then flows through the sample line and the particulates are collected on a sample pliter. The sample fliters are replaced woekly, and somotimes more often. The flitered gas then flows through two sliver zeollte cartridges to capture lodine and other volattle elements. Section 4.3 .6 describes the calfbration of the sample flow rate measurement equipment.

No Irradiated fuel has been introduced into the PUREX Plant for several years. No dissolutions have been performed since 1 ate 1989. caseous sampling systems had shown that the levels of ${ }^{3} \mathrm{H}$ and ${ }^{\mathrm{T}} \mathrm{C}$ had fallen to levels at or below the andytical dotection limit, which were woll below environmental release and monitoring 1 imlts. Consequently, sampling for these nuclides is no longer roquired or performed. The release of other radloactive gases decreased more rapidly than for these nuclides. Consequently, there is no noed for gaseous nuclide sampling.

4.3.5 A daseription of the laboratory analvels procedures used for each radionucllde measured, including irequency of analyols, callbration procedures and frequency of callibration.

The Facility Effluent Monitoring Plan Determination for the 200 Area Facilities (WHC 1991b) 11sts, the anglytes of Interest for the

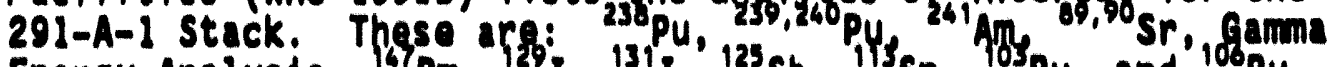

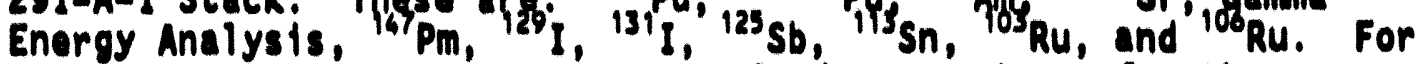
a description of the laboratory analysis procedures for these analytes, see Appendix $G$.

4.3.6 A deserfotion of the semple flow rate masurement syotem or procedures, Including callibrotion procedures and irequency of collibration.

After extting the record sample fliter, the afr flows through a flow measurement and control system. Currentiy a Kurz* Model 505 system measures the sample flow rate, a Kurz model 101-RM totallzes the sample flow, and a Kurz 710RMO(4200) adjusts a control valve to maintain a constant flow. At least once a day an employee adjusts the 710RMD to ensure isokinesis. The instruments are callbrated at least once per year (normally every 6 months). Currently the callbration procedures are PSCP-1-045, PSCP-4-167, and PSCP-4-197. After exiting the flow control valve, the air flows through a rotameter which provides backup indication. Approximately yearly callbration is accomplished by comparison with a standard rotameter, using procedure PSCP-7-001.

4.3.7 A aescription of effluene flow rate masurement procedures, Including frequency of measurements, callibration procedures and frequency of call lbretion.

A six-point Kurz probe continuously measures the flow through the stack at the 74-foot level. A Kurz Model 195B transmitter sends the stgnal to a Kurz Model 142-RMD and a Kurz Model 132, whtch then drives a recorder, which continuousiy records the fiow rate. The

*Kurz is a trademark of Kurz Instruments, Inc. 
total flow is recorded on a digltal integrator, or can alternately be summed from the recorder trice. The $s 1 x$ flow eloments on the six-point probe are pre-callbrated by the manufacturer. The remaining instruments are callbrated at least once per yoar (normally overy 6 months). Currently the callbration procedures are PSCP-1-044, PSCP-4-001, and PSCP-4-167.

4.4 The objectives of the quallty essurance progrem shall bo documented end ohall state the reculred precision, secursecy, and completenese of the emisesion moseurcment date Including deseription of the procectures used to eseceses these parematers.

Soe Append $1 \times 6$.

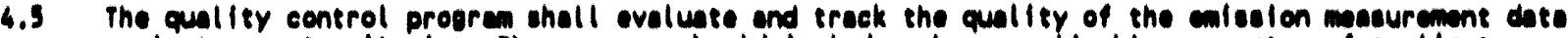
agalnat preset erlterla. The program thould include, where applicable, a evetem of replleatesi splked sumplest apllt smples; blanks; and control charts. The member and frequeney of such qualley control checks thall be ldentifled.

See Appendix 6.

4.6 A sumple tracking system thall be established to provide for positive identiffeatlon of semples and date through all phases of the sempling collection, unalyale, and reporting ovetem. emple hendline and presurvation procedures shall be establlahed to maintain Integrity of the semples during collection, storage, and analyels.

\section{Refer to Section 6.2 .3 of the main part of this document.}

4.7 Perlodle Internal and external audits ohall be porformed to monltor compllanee wlth the quallty eseurance progran. Phese sudits thall be performed in eccordance with writeten procedures ond conducted by persermel the do not have respons fbllity for parforming any of the oparations being oudl ted.

Refer to Section 7.0 of the main part of this document.

4.8 A correctlve ection progrem shall be established including criterla for when correctlve actlons wlil be taken and who is reaponstble for taking the corrective ection.

Refer to Sections 4.0 and 7.0 of the main part of this document.

4.9 Perlodic reports to respons blb managoment shall be prepared on the parformance of the conleslon masurements propren. These reports should inelude assesement of the qualley of the date, results of audits, and deseription of correcelve ectlons.

Refor to Section 9.0 of the main part of this document.

4.10 Provlde quallfleatlons and training needed for facllity cognizant engineer.

WHC-CM-5-9, Section 2.19, REV O, SELECTION OF PUREX/UO 3 COGNIZANT ENGINEERS AND COGNIZANT ENGINEER MANAGERS. This procedure establishes the requirements, qualiflcations, and process for the solection of PUREX $/ \mathrm{UO}_{3}$ Cognizant Engineors and Cognizant Engineor Managers. 


\section{REFERENCES}

ANSI, 1969, Guide to Sampling Airborne Radioactive Matelials in a Nuclear Facility, ANSI N13.1, American National Standards Instituis, Washington, D.C.

EPA, 1992, "Standards of Performance for New Stationary Sources," Title 40, Code of Federal Regulations, Part 60, U.S. Environmental Protection Agency, Washington, D.C.

PSCP-7-001, AIR ROTAMETER, CALIBRATION PROCEDURE

PSCP-4-197, KURZ MODEL 710 RMD FLOW CONTROLLER, 4200 AND 7500 SYSTEMS

PSCP-4-167, KUIRZ SAMPLE LOW TOTALIZER, MODEL 101

PSCP-4-001, TAY'LOR QUICK-SCAN RECORDER, SERIES 1300, CALIBRATION PROCEDURE

PSCP-1-045, KURZ LINEAR MASS FLOW METER, SERIES 505 AT PUREX

PSCP-1-044, KIJRZ 142/151 RM, CALIBRATION PROCEDURE

WHC, 1991a, Health Physics Procedures Manual, as amended, WHC-IP-0692, Westinghouse Hanford Company, Richland, Washington.

WHC, 1991b, Faciitity Effluent Monitoring Plan Determination for the 200 Area Facilities, WHC-EP-0440, Westinghouse Hanford Company, Richland, Washington.

WHC, 1992a, Health Physics Practices Manual, as amended, WHC-CM-4-12, Westinghouse Hanford Company, Richland, Washington.

WHC, 1992b, Westinghouse Hanford Company Emergency Plan for PUREX Facility, WHC-IP-0263-202A, Westinghouse Hanford Company, Richland, Washington.

WHC, 1992c, PUREX/UO 3 Plant Occurrence Categorization, Notification, and Reporting, as amended, WHC-CM-5-9, Westinghouse Hanford Company, Richland, Washington. 


\section{WHC-EP-0536-1}

This page intentionally left blank. 
WHC-EP-0536-1

\section{APPENDIX B \\ METHOD 114 COMPARISON FOR STAL, ' - B-1}

J. A. Koerner 


\section{WHC-EP-0536-1}

This page intentionally left blank. 
APPENDIX $B$

\section{METHOD 114 COMPARISON FOR STACK 291-B-1}

This section provides a line-by-line evaluation of quality assurance method requirements outlined in 40 CFR 61, AppendiX B, Method 114, as they apply to the 291-B-1 stack at the B Plant, Hanford Site.

\subsection{Purpose and Background}

This method provides the requirements for: (1) stack monitoring and sample collection methods appropriate for radionuclides; (2) radiochemical methods which are used in determining the amounts of radionuclides collected by the stack sampling and; (3) quallty assurance methods which are conducted in conjunction with these meesurements. These methods are appropriate for emissions for stationary sources. A list of references is provided.

Many different types of facilities release radionuclides into alr. These radionuclides differ in the chemical and physical forms, half-lives and type of radiation emitted. The approprlate combination of semple extraction, collection and analysis for an Individual radionuclide is dependent upon many interrelated factors including the mixture of other radionuclides present. Because of this wide range of conditions, no single method for monitoring or sample collection and analysis of a radionuclide is epplicable to all types of facilities. Therefore, series of methods based on "principles of measurement" are described for monitoring and semple collection and analysis which are applicable to the measurement of redionuclides found in effluent streans at stationary sources. This approach provides the user with the flexibility to choose the most appropriate combination of monitoring and sample collection and analysis methods which are applicable to the effluent stream to be measured.

\section{No response requitred.}

\section{0 stack Monitoring and Sample Collection Methods}

Monitoring and sample collection methods are described based on "principles of monitoring and sample collection" which are applicable to the measurement of radionuclides from effluent streams at stationary sources. Radionuclides of most elements will be in the particulate form in these effluent streams and can be readily collected using a sultable fllter media. Radionuclides of hydrogen, oxygen, carbon, nitrogen, the noble gases and in some circumstances lodine will be in the gaseous form. Radionuclides of these elements will require elther the use of an in-line or off-line monitor to directly measure the radionuclides, or suitable sorbers, condensers or bubblers to collect the radionuclides.

2.1 Radionuclides as Particulates. The extracted effluent stream is passed through a filter media to remove the particulates. The filter must have a high efficiency for removal of sub-micron particles. The guidance in ANSI N13.1-1969 shall be followed in using filter media to collect particulates (incorporated by reference-see Section 61.18).

The Gelman Versapor 3000 filter medium is an acrylic copolymer membrane supported by a non-woven nylon fabric. The manufacturer rates the efficiency of this medium at 91 percent for $0.3-\mu \mathrm{m}$ aerosol. The manufacturer recently tested 24 samples with a $0.3-\mu m$ di-octyl phthalate aerosol per ASTM D 2986-71. The measured average efficiency was 95.8 percent and the standard deviation was 1.6 percent, which supports the rated efficiency.

2.2 Radionuclides as Gases.

The 291-B-1 Stack does not exhaust radionuclide gases; therefore, this section is not applicable to this stack (WHC 1991a).

\subsection{Definition of Terms}




\subsection{Radionuclide Analysis Methods}

A serles of methods based on "principles of measurement" are described which are appllable to the analyale of radionuclides collected from irborne effluent streane ot statlonary sources. These methods are applicable only under the conditions steted and within the limitatione described. Some methods specify that only single redionuclide be present in the semple or the chemically separated sample. This condition should be interpreted to mean that no other radionuclides ore present in quantities which would interfere with the measurement.

Also ldentifled (Table is are methods for solected llst of radionuclides. The llsted radionuclidas are those which are most commonly used and which have the greatest potential for causing doae to members of the public. Use of methods based on principles of messurement other than those described in this section must be approved in advance of use by the Adninistrator. For radionuclldes not listed in Table 1, any of the described mathods may be used provided the user can demonstrate that the appl fabillty conditions of the method have been mat.

The type of method applicable to the analysis of a radionuclide is dependent upon the type of radiation emitted, 1.e., alpha, beta or gamma. Therefore, the methods described below are orouped according to principles of measurements for the analysis of alphe, bete and ganme emitting radionuclides.

\subsection{Methods for Alpha Emitting Radionuclides}

\subsubsection{Method A-1, Radiochemistry-Alpha Spectrometry.}

Principle: The element of interest is seporated from other elements, and from the semple matrix using radiochemical techniques. The procedure may involve precipitation, ion exchange, or solvent extraction. Carriers celements chemically similar to the element of interest) may be used. The element is deposited on a planchet in a very thin fllm by lectrodeposition or by coprecipitation on a very small amount of carrier, such as lanthanum fluoride. The deposited element is then counted with an alpha spectrometer. The activity of the nuclide of interest is measured by the number of alpha counts in the appropriate energy region. A correction for chemical yield and counting efficiency is made using a standardized radioactive nuclide (tracer) of the same element. If a radioactive tracer is not ovailable for the element of interest, a predetermined chemical yield factor may be used.

Apolicabillity: This method is applicable for determining the activity of any apha-enteting radionuclide, regardiess of what other radionuclides are present in the sample provided the chemical separation stap produces a very thin semple and removes all other radionuclides which could interfere in the spectral region of interest. APHA-605(2), ASTM-0-3972(13).

The 222-S Laboratory method involves dissolution (LA-549-112), chemical separation (LA-943-123), electrodeposition (LA-542-101), followed by alpha spectrometry (LA-508-051) (WHC 1992b). It meets all the requirements of the EPA-suggested method. This is used for analyzing ${ }^{241} \mathrm{Am},{ }^{238} \mathrm{Pu}$, and $239,240 \mathrm{pu}$ in the air filter samples. The activities of these radionuclides are determined by direct comparison with the recoveries of (National Institute of Standards and Technology [NIST] traceable) ${ }^{243} \mathrm{Am}$ and ${ }^{236} \mathrm{Pu}$ tracers.

\subsubsection{Method A-2, Radiochemistry-Alpha Counting.}

Principle: The element of interest is separated from other elements, and from the sample matrix using radiochemistry. The procedure may involve precipitation, ion exchange, or solvent extraction. Carriers celements chemically similar to the lement of interest) may be used. The element is deposited on a planchet in a thin film and counted with a alpha counter. A correction for chemical yield (if necessary) is made. The alpha count rate measures the total activity of all emitting radionuclides of the separated element.

Apolicability: This method is applicable for the measurement of any alpho-emitting radionuclide, provided no other alpha emitting radionuclide is present in the separated sample. It may al so be applicable for determining compliance, when other radionuclides of the separated element are present, provided that the calculated emission rate is assigned to the radionuclide which could be present in the sample that has the highest dose conversion factor. $100-12096(18)$. 
Because the tracer technique is used in the separation process, this method is not used for air filter analysis.

\subsubsection{Method A-3, Direct Alpha Spectrometry.}

Principle: The sample, collected on a sut table fllter, is counted directly on an alpho spectrometer. The sample must be thin enough and collected on the surface of the filter so that any absorption of alphe particle energy in the sample or the filter, which would dagrade the spectrum, is minimal.

Apolicability: This mathod is applicable to simple mixtures of alphe emitting radionuctides and only when the amount of particulates collected on the filter paper are relatively small and the alphe spectra is adequately resolved. Resolut lons should be $50 \mathrm{keV}$ (FWHM) or better, ASTM-0-3084(16).

The 222-S Laboratory method follows the procedure L0-150-133, then LA-508-110 for total al pha counts, and finally LA-508-051 for alpha spectrometry (WHC 1992b). It partially meets the requirements of the EPA method. This method is usually used for emergency air samples. The sample is counted on the alpha counter of known efficiency to obtain the total alpha counts. In the alpha energy analysis (AEA), the relative peak fractions of different alpha emitters identified in the sample are determined. The peak fractions are then used to correct the total alpha counts and thus determine the activities of individual alpha radionuclides present in the sample.

3.1.4 Method A-4, Direct Alpha Counting (Gross alpha determination).

Princiole: The sample, collected on a suitable filter, is counted with an alpha counter. The sample must be thin enough so that self-absorption is not significant and the filter must be of such a nature that the particles are retained on the surface.

Apollcabillty: Gross alpha determination may be used to measure emissions of specific radionuclides only (1) when it is known that the sample contains only a single radionuclide, or the identity and isotopic ratio of the radionuclides in the sample are well known, and (2) measurements using either Mathod $A-1, A-2$ or $A-5$ have shown that this method provides a reasonably accurate measurement of the emission rate. Gross alpha measurements are applicable to unidentified mixtures of radionuclides only for the purposes and under the conditions described in section 3.7. APHA-601(3), ASTM-D-1943(10).

The 222-S Laboratory method follows procedure LA-508-110 or LA-508-114. It meets all of the requirements stated in Method $A-4$.

3.1.5 Method A-5, Chemical Determination of Uranium.

Uranium: Uranium may be measured chemically by either colorimetry or fluorometry. In both procedures, the sample is dissolved, the uranium is oxidized to the hexavalent form and extracted into a sultable solvent. Impurities are removed from the solvent layer. For colorimetry, dibenzoylmethane is added, and the uranium is masured by the absorbance in a colorimeter. For fluorometry, portion of the solution is fused with a sodium fluoride-lithium fluoride flux and the uranium is determined by the ultraviolet activated fluorescence of the fused disk in a fluorometer.

Applicability: This method is applicable to the measurements of emission rates of uranium when the isotopic ratio of the uranium radionuclides is well known. ASTM-E318(15), ASTM-D-2907(14).

Total uranium is determined by procedure LA-925-107. The laser-induced kinetic phosphorescence analyzer is an improvement over the old fluorometric method for uranium determination. It is highly sensitive (lower detection level 
of 50 parts per trillion is quite possible) because the laser frequency is used specifically for excitation of uranfum atoms. It is faster and produces more reliable results. Quality can also be monitored during analysis. It exceeds the requirements in Method A-5.

\subsubsection{Method A-6, Radon-222-Continuous Gas Monitor.}

Princlole: Rodon-222 is masured directly in a continuously extran, mple streen by passing the air etreem through callibrated acintillation cell. Pric, the scintillation cell, the air streen is treated to remove particulates at excess molsture. The alphe particles from radon-222 and its decey products strike zine sulfide coating on the inside of the scintillation coll producing light pulses. The light pulses are detected by photomultiplier tube which generates electrical pulses. These pulses are processed by the system electronics and the read out is in pCI/I of radon-222.

Apolicability: This mothod is applicable to the messurement of radon-222 in efflluent streams which do not contein significent quantities of radon-220. Users of this mathod should callibrate the monitor in a radon callbration chember at least twice par year. The background of the monitor should al so be checked perlodically by operating the

instrument in a low radon enviroment. EPA 520/1-89-009(24).

\section{Not applicable at the 222-S Laboratory; direct monitoring of ${ }^{222} \mathrm{Rn}$ is not performed at the 222-S Laboratory.}

\subsubsection{Method A-7, Radon-222-Alpha Track Detectors}

Princiole: Radon-222 is measured directly in the effluent stream using alphe track detectors (ATD). The alpha particles emitted by radon-222 and its decay products strike a small plastic strip and produce submicron danage tracks. The plastic strip is placed in a caustic solution that accentuates the damage tracks which are counted using a microscope or automatic counting system. The number of tracks per unit area is corrected to the radon concentration in air using conversion factor derived from data generated in a radon callbration facllity.

Apolicablllty: Prior approval from EPA is required for use of this method. This mothod is onty applicable to effluent streams which do not contain significant quantitios of radon-220, unless special detectors are used to discriminate against radon 220. This method may be used only when ATDs have been demonstrated to produce data comparable to data obtained with Method A-6. Such data should be submitted to EPA when requesting approval for the use of this method. EPA 520/1-89-009(24).

Not applicable; direct monitoring of ${ }^{222} \mathrm{Rn}$ is not performed at the 222-S Laboratory.

\subsection{Methods for Gaseous Beta Emitting Radionuclides.}

3.2.1 Method 8-1, Direct Counting in Flow-Through lonization Chambers.

Principle: An lonization chamber containing a specific volume of gas which flows at a given flow rate through the chamber is used. The semple (effluent stream semple) acts as the counting gas for the chamber. The activity of the radionuclide is determined from the current measured in the ionization chamber.

Apolicability: This method is applicable for measuring the activity of a gaseous beta emitting radionuclide in an effluent stream that is suitable as a counting gas, when no other beta-emitting nuclides are present. DOE/EP-0096(17), NCRP-58(23).

Not applicable; not performed. 
3.2.2 Method B-2, Direct Counting With in-line or off-line Bete Detectors.

Pringloles The beta detector is placed directly in the offluent atrean (In-line) or an extracted semple of the effluent stream le pasead through a chamber containing a bets detector coff-line). The activities of the radionuclides present in the effluent etreem ore determined from the bete count rate, and a knowledge of the redionucl ldes present and the relationahip of the grose bete count rate and the specifle radionuclide concentretion.

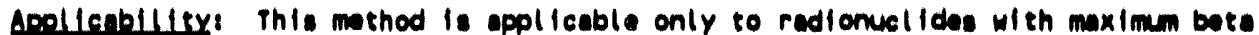
pertlele energies greater then $0.2 \mathrm{MoV}$. This mothod may be used to meseure emlestone of epecific radionuclldes only when $I_{t}$ is known that the semple conteine only. ingle radionuclide or the identity and leotople ratlo of the redionuclides in the offluent streem are well known. spacific redionuclide analyels of perlodic grab exples may be used to identify the types and quantities of radionuclides preaent and to establish the relationship between epecific radionuclide analyses and grose bets count rates.

This method is applicable to unident lfled mixtures of gaseous radionuclides only for the purposes and under the conditlons deseribed in section 3.7.

Not applicable; not performed.

3.3 Methods for Non-Gaseous Bete Enitting Redionuclides.

3.3.1 Method B-3, Radiochemistry-Bete Counting.

erinciple: The element of interest is seperated from other elemente, and from the semple matrix by rediochemistry. This may involve precipitation, distillation, ion exchange, or solvent extraction. Carriers celements chemically similar to the element of interest) may be used. The element is deposited on a planchet, and counted with. beta counter. Corrections for chemical yield and decay (if necessary) are made. The beta count rate determines the total activity of all radionuclides of the separated - lement. This method may also involve the radlochemical separation and counting of a daughter element, after sultable period of ingrowth, in which case it is specific for the parent nuclide.

Applicabillity: This method is applicable for measuring the activity of any beta-emitting radionuclide, with a maximum energy greater than $0.2 \mathrm{MeV}$, provided no other radionuclide is present in the separated semple. APHA-608(5).

The method for determining ${ }^{89} \mathrm{Sr},{ }^{90} \mathrm{Sr} /{ }^{90} \mathrm{Y}$ in air filter samples is carried out using procedures LA-549-112 (dissolution) and LA-220-103 (for chemical separation), followed by procedure LA-508-111 (total beta counting). The laboratory method certainly meets the requirements stated above.

\subsubsection{Method B-4, Direct Beta Counting (Oross beta determination).}

Principle: The sample, collected on a suitable filter, is counted with a beta counter. The sample must be thin enough so that self-absorption corrections can be made.

Apollcability: Gross beta measurements are applicable only to radionuclides with maximum beta particle energies greater then $0.2 \mathrm{MeV}$. Gross beta measurements may be used to measure emissions of specific radionuclides only (1) when it is known that the sample contains only a single radionuclide, and (2) measurements made us ing Method B-3 show reasonable agreement with the gross beta measurement. Gross beta measurements ore applicable to mixtures of radionuclifes only for the purposes and under the conditions described in Section 3.7. APHA-602(4), ASTM-0-1890(11).

For gross beta determination, procedure LA-608-110 or LA-508-114 is followed. It satisfies the Method B-4 requirements. 
3.3.3. Mothod 1.3, Lquid seintillation spectromatry.

Peinaloles an allquot of a collected semple or the reault of some other chemical

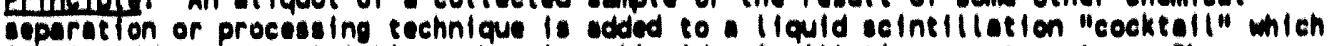
is viewed by photomulelplior tubes in a llauld ecintillation epoctrometer. The spectrometer is edjusted to establish a chanmal or "window" for the pulse emergy approprlote to the muclide of intereat. The ectivity of the nuclide of interest 10 meneured by the counting rete in the approprlate enerey chemel. Corrections are mede for chemical vield where esparations ore made.

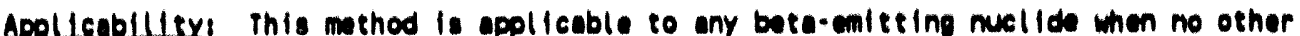
redtonuct do is present in the semple or the separated sumple providad thet it cen be incorporated in the seintillation cocktall. This method is also applicable for semples which contain more then one redionuclide but only when the energles of the bate particles ore sufficlently separated to that they cen be resolved by the apectrometer. Thls mothod is most appllabble to the measurement of low-energy beta emitere such es tritiun and carbon-14. APHA.609(6), EML LV-539-17(19).

This method is used for determining ${ }^{147} \mathrm{Pm}$ in air fllter samples (LA-549-112 for dissolution, LA-613-111 for chemical separation, LA-548-111 for incorporating into scintlllation cocktall, and LA-508-121 for llquid sciptillation counting). This is also used for determination of ${ }^{14} \mathrm{C}(L A-348-101$, LA-548-11L, and LA-508-121, sequent 1 ally) and ${ }^{3} H$ (LA-218-112, LA-548-111, and LA-508-121, sequentlally) in gas samples. This method satisfies all of the requirements.

\subsection{Garma Emitting Radionuclides}

\subsubsection{Method 6.1. High Resolution Garme spectrometry.}

Principles the semple is counted with o hlgh resolution gemo detector, usually elther - oe(t) or a high purfity oe detector, connected to e multichannal analyzer or computer. The germe emitting radionuclides in the semple are masured from the gemme count retes in the energy reglone characterietle of the individual redionuclide. Corrections are made for counte contributed by other radionuclides to the epectral regions of the radionuclides of interest. Radio-chemical separations may be made prifor to counting but are usually not necessery.

Apollacabllity: This method is appl fcable to the masurement of eny germe enitting radionucldo with garme energies greater than $20 \mathrm{kev}$. It can be opplied to complex mixtures of radionuclidas. The semples counted may be in the form of partleulate fliters, absorbers, liquids or goses. The method may also be applied to the onalyels of goseous germa emitting redionuclides directly in on effluent streem by paseing the strean through a chanber or cell conteining the detector. AsTM-3649(9), 100-12096(18).

The 222-S Laboratory method uses gamma ray spectroscopy with high-resolution germanium detectors and follows procedure LA-508-052. It meets all the requirements explained in Method G-1.

\subsubsection{Method 0.2, Low Resolution Garma spectrometry.}

Princlole: The sample is counted with - low resolution gemm detector, a thallium activated sodium lodide crystal. The detector is coupled to a photomultiplier tube and connected to multichannel analyzer. The gamm emitting radlonuclidea in the sample are measured from the garm count rates in the energy reglone characteristic of the individual radionuclides. Correctlons are made for counte contributed by other radionuclides to the spectral regions of the radionuclides of interest. Radiochemical separation may be used prior to counting to obtain less complex gamm apectre if neoded. 


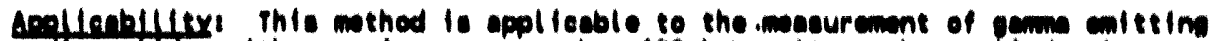

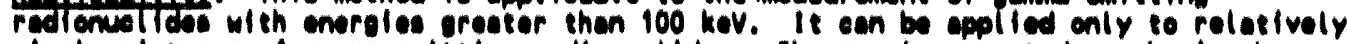

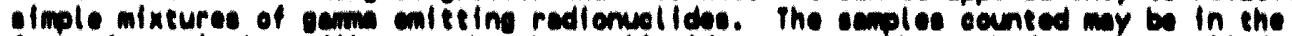

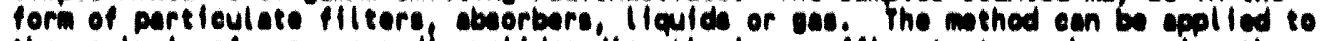

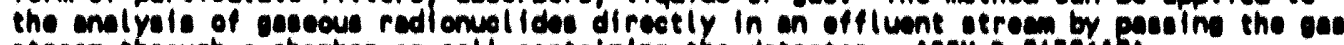
strecm throwah chember or cell centeining the dotector. AstM-0-2659(12). EMSL -LV-0539-17(19).

\section{Not applicable, because this mothod is not used in air fliter analysis.}

\subsubsection{Wothed 0.3, single Chernel oemme spectrometry.}

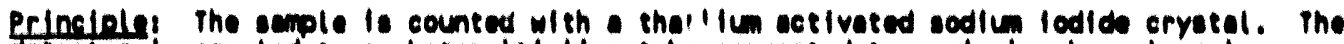
detoctor is coupled to a photomuleffller tube comnected to a ingle chamel anclyzer.

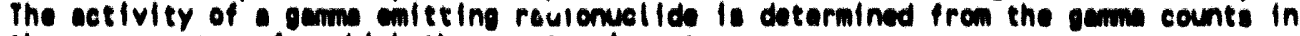
the eneroy range for whlch the counter lo set.

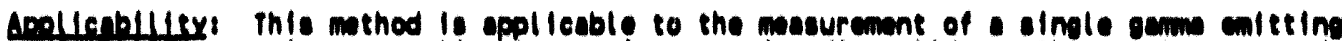
redionusttde. It ls not oppl leable to wixtures of redionucl labs. The semples counted may be in the form of parfleulate fllters abeorbers, llevids or gas. the minthed cen

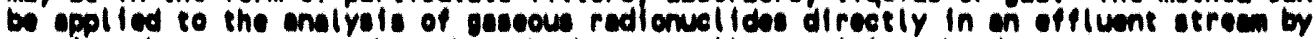
paseing the gas strecen through o cherbar or cell centaining the dotector.

\section{Not applicable, because this technique is not used in air} pllter analysts.

\subsubsection{Mothod 0.4, orose Game counting.}

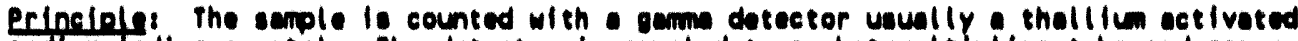

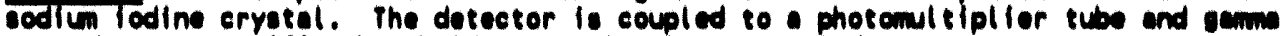
rays above apeclfle threahold eneroy level ore counted.

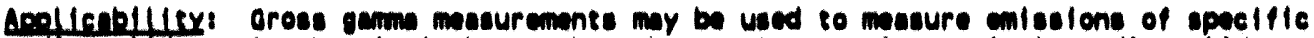
radonuctides only then it ls known that the semple conteins o ingle redionucl lds or the Identity and isotople ratlo of the redionuclides In the effluent etrecm are wall known. Then grose gamm maneurements are used to dotermine comlestons of apecifle radionuclldas parlodic mesourements using Mothods 0.1 or 0.2 should be made to demonstrate that the grose germa masuremente provide rellable emiseston dato. This mothod may be applled to analyols of gnseous redionuelldes directly in on effluent stream by placing the detector directly in or adjecent to the effluent etrocen or paseing an extracted sample of the effluent atream through a chember or cell containing the detector.

\section{Not applicable.}

3.5 Counting Mathods. All of the mothode with the exception of Mothod A.5 Involve counting the rediation emitted by the redionuclide. Counting mothode applicable to the massurement of alphe, bete and gamm rediations are lieted below. The equlpment meeded and the counting principles involved ore deseribed in dotall in $A 8 T M-3648(8)$.

\subsubsection{Alphe Countingt}

- Qas Ploy Proportional Counters. The olphe particles cause ionization in the counting ges and the resulting electrical pulses ore counted. These counters may be windowless or have very thin windows.

- Scintillation Counters. The olphe particles tranafer eneray to o ecintillator resulting in a production of lloht photone whlch strike a photomultipller tube converting the light photons to electrical pulses thich are counted. The counters may involve the use of solid ecinelliation materials such as zine sulfide or liquid seintillation solutione.

- Solid-stete Counters. Semiconductor materials, such os sllicon surface-barrier p.n Junctions, act as sollid Ionization chambers. The alphe particles interact which the dotector producing electron hole poire. The charged pair is collected by an applled electrical fleld and the resulting electrical pulses are counted. 
- Alpha spectrameters. Semlconductor detectora used in conjunetion with militchemel onalyiers for emerey diserimination.

Alpha proportional counters (home-bullt chambers with Eace ORTEC electrontes), window-type gas flow proportional counters (some having automatte sumple changer), surface-barrfor solid-state detectors connected to a mult tchannol analyzer (MCA) (Sortes 88, Juplter system manufactured by Canberra Industrles, Inc.) are used for atr fliter analysis in the 222-s Laboratory. Laboratory equipment meets the specifleations for alpha counting.

\subsubsection{Dete Countingt}

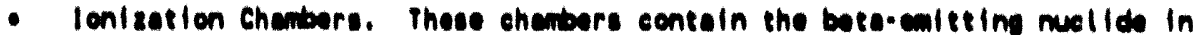
sessecus form. The ionization current proctused le moseured.

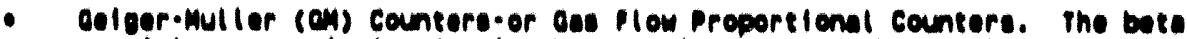
particles cause lonization in the counting oos and the resulting electricel pulses ore counted. Proportlenal ges flow counters mileh ore heevilly ahlelded by lead or other metal, and provlded with on entl-colneldenee ohleld to relect coemle rave, are colled low beckeround bete counters.

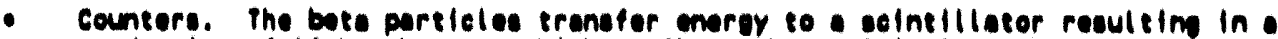
production of Ilght photons, whleh otrike ohotemulefipller sube cenvertin the

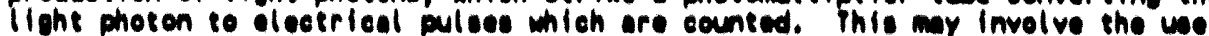

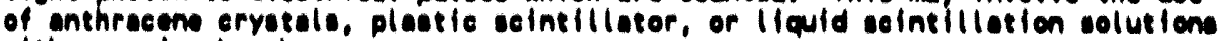
wleh organie phosphors.

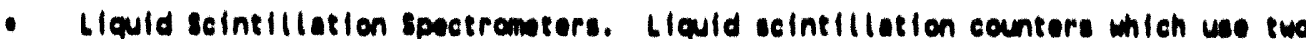
photomultipller tubes in colncldence to reduce background counte. Thle counter may olso ol ectronically diecrininate unong puleces of olven range of enerey.

Window-type gas flow proportional counter (some having an automatic sample changer) liquid scintlliation spectrometors manufactured by Beckman Instruments, Inc. are used for analysis. The 222-S Laboratory counting equipment moets the requirements spectfled above for bota counting.

\subsection{3 ocmu Countingt}

- Low-Resolution Gemm spectrometers. The gemm raye interact with thollium ectiveted sodium lodide or ceslum lodide ervetol resulting in the rel onse of llghe photons which strike a photomultipller tube converting the llght pulses to electrical pulses proportional to the energy of the gemme rey. Mulef-channal anolyzers ore uaed to separate and store the pulses according to the energy absorbed in the eryetel.

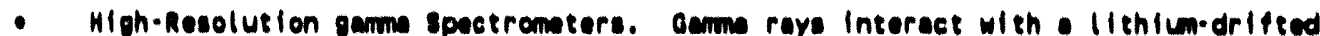
(Co(Li)) or hlgh-purlity germanlum (HPGe) semiconductor datectors resulting in production of electron-hole pairs. The charged pair is collected by on apolled - lectrical fleld. A very stable low nolse preamplifler ampliflas the pulses of - lectrical charge resulting from the gemm photon interections. Multichamel enalyzers or comouters are used to separate and store the pulses eccording to the energy absorbed in the crystal.

- single Chamel Analyzers. Thallium ectivoted sodiun lodide crystals used with a single window anolyzer. Pulses from the photomultipllor tubese ore esepreted in - single predoterminad eneroy range. 
WHC-EP-0536-1

High-resolution garma dotectors (high-purity gormanlum [HPGe] detectors for both low and high onergtes) from EGSO ORTEC and Princeton Garma Tech and woll-type pure be dotectors connected to MCA (Canberra's Juplter system) are avallable and used for air fliter analysis. Our equipment exceeds the requirements for garma counting spectfled above.

3.3.6 Callbration of Counters. Counters are cellbreted for speclfle redionucllde mesuremente veing e itandard of the radionuclide under olther Identicel or very imilar conditlone as the semple to be counted. For aume spectroneters a sorles of standards covering the energy renee of interest may be used to censtruct a callbration curve reloting geime energy to counting efflelency.

In those cases where atandard lo not avallable for a redlonucl lde, countere may be

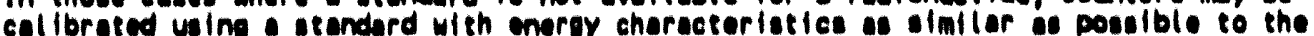
redionvell fo to be measured. Por grose alphe and bete meseurements of the unidentifled mixtures of redionuclidas, al phe counters ore collibroted with a natural urenium etenderd and bete counters wlth o ceslum.137 standard. The standard muse contain the

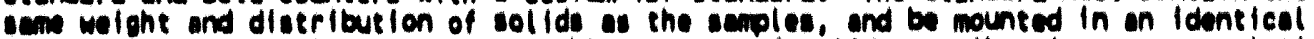
mamer. If the semples contein veriable mounte of solida, callbration curves relating velohe of solld present to counting efflctency ore prepared. standorde other than those preseribed may be used provided it cen be shown that auch utenderds are more epplleable to the redionuclide mixture masured.

A mixod gamma standard (NIST traceable) enftting varfous gamma-rays ranging from 69 to $1,850 \mathrm{koV}$ is usod, using vendor-supplied callbration software, for constructing offletency versus energy callbration curves for different geomotrical conflgurations used in gamma analysis. The calloration procedure for gamma ray spectromotor is documented In LQ-508-003. Our callibration procedure meots the EPA crlterla for gamm ray spectroscopic analysis.

For calibration of beta detectors for ${ }^{90} \mathrm{Sr} /{ }^{90} \mathrm{Y}$ analysis, procedure LQ-508-002 is used in conjunction with LQ-508-005. It meets the requirements of the method specifled above. A method standard also is used to check the performance and calloration of the detector.

For callbration of alpha-beta proportional counters, the procedure LQ-508-002 is carried out. It partially devlates from the EPA requirements. For gross alpha and gross beta measurements, our instruments are callbrated with ${ }^{249}$ An and ${ }^{60} \mathrm{Co}$ standards, respectively. The reasons for choosing the $24 \mathrm{Am}$ standard for alpha calibration are as follows:

- It is commoniy found in the main stack air samples

- Alpha counting efflctency usually is the same for other alpha emitters that also are found in the air stack samples

- The ${ }^{241}$ Am standard also can be checked independently by gamma analysis.

The reason for using the ${ }^{60} \mathrm{Co}$ standard for beta callbration is the lower counting efficiency with ${ }^{60} \mathrm{Co}$ (beta $\max =317 \mathrm{keV}$ ) compared to those with ${ }^{3}{ }^{C S}$ (beta max $=511 \mathrm{keV}$ ) and ${ }^{90} \mathrm{sr}$ (beta $\max =546 \mathrm{koV}$ ). Consequently, it will generate conservative numbers in our analyses. 
The callbration curves relating wolght of solids present to counting offictencles are not done in alpha-beta analys 1 , but currentily are being evaluated.

3.6 Redlochemicel Mathode for selected Redionucllose. Methods for a enlected Ilat of redionucllates

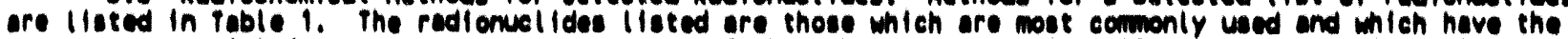
greatest potential for causing doses to members of the publle. For redlonucllades not llsted in rable 1 , mathods based on any of the appl leable "princlples of mosurement" deseribed in section 3.1 through 3.4 may be used.

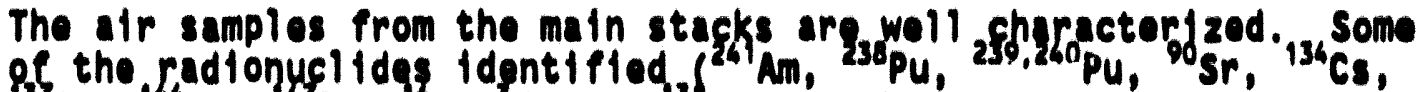

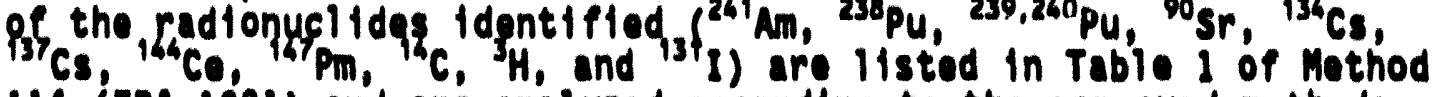
114 (EPA 1991) and are analyzed according to the apprgyed mothods

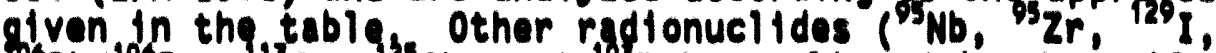
${ }^{106} \mathrm{Rh} /{ }^{106} \mathrm{Ru},{ }^{13} \mathrm{Sn},{ }^{225} \mathrm{Sb}$, and $\left.{ }^{103} \mathrm{Ru}\right)$ not 11 sted in the table are analyzed by the mothods outlined in Mothod 114, depending on the type of enitted radiftion. It is important to note here that the radionuclides ${ }^{93} \mathrm{Zr}$, ${ }^{3} \mathrm{Nb}$, and ${ }^{103} \mathrm{Ru}$ have noarly decayed to nondetectable levels because no product is being produced.

3.7 Applleabillty of Orose Alphe and Bete Measurements to Unidentifled MIxtures of Redlomuclldes.

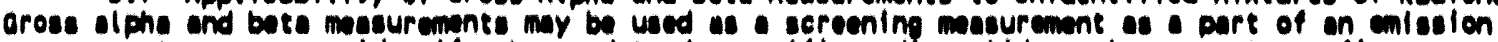

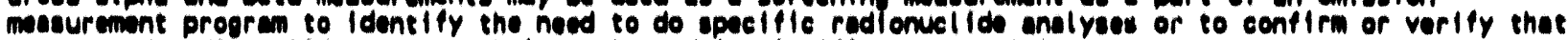
unoxpected radionuclides are not boing released in slenlflcent quantictes.

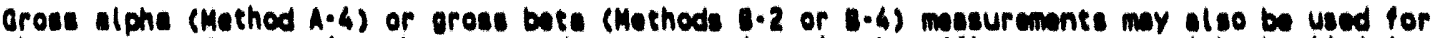
the purpose of compering the measured concentrations in the effluent etrecen with the limiting "Concentration Levels for Enviromental Compllence" in Table 2 of Appendix 6 . For unidentifled mixtures, the mesaured concentration volwe shall be compared with the lowest enviromental concentration limit for ony radionuclide which le not known to be abuent from the offluent stroem.

This is not applicable, because the afr effluents from the Hanford stte main stacks are well characterlzed. However, gross alpha and beta analyses for weokly and dally alr samples are routinely performed in the 222-5 Laboratory before starting speciffe radionuclide analyses. Following this practlce, the facllity can vertfy a signtflcant release of a radionuclide into the atr so corrective actions to minimize radionuclide emission into the environment can be taken promptly by facllity personnel. The gross alpha and bota results from analys is are compared to those if sted in the appendix of DOE Order 5400.5 (DOE 1990) for compliance.

\subsection{Qualley Assurance Methods}

Each facilley required to masure their radionuclide emiselon shall conduct auallty assurence progrem in conjunction with the redionucllde onission messurements. This prosrm shall aseure that the emiselon measurements are representeplve, and ore of known preciston and accuracy and shall include edminiserative controls to essure prompt response then enlseion meseurements indlcate unexpectedly large emiselons. The program shall consist of system of polleles, organlzational responelbilities, written procedures, data quality epecifleations, audits, corrective actions and reports. This qualley eseurance progrem shall include the following progrem elements:

4.1 The organizetional stlucture functional respons /bllltles, levels of euthority and lines of commenications for all ectivitles related to the emiselons messurement progrem shall be identifled and documented.

For ti:e organizational structure, refor to section 6.2 of WHC-EP-0536.

4.2 Adninistrative controls shall be preseribed to ensure prompt response in the event that emisesion levels increase due to unplanned operations. 
WHC-CM-4-1, REV 1, Emergency Plan (WHC 1992C). This manual contains an emergency preparedness plan to protect onsite personnel, public health and safety, and che environment in the event of operation, natural phenomena, and/or safeguards and security events at Hanford Site Facilities. The requirements stated in the emergency preparedness plan are implemented through subtior plans and implementing procedures. These implementing plans and procedures established for response to emergencies by Hanford Site personnel and emergency management organizations are contained in WHC-CM-4-43, Emergency Management Procedures; WHC-CM-4-44, Emergency Preparedness Administrative Manual; various building emergency plans; and Hanford Site Facility operating procedures (WHC-IP-0263-BPC) (WHC 1992a).

WHC-CM-4-12, Section 1.14, REV O (WHC 1992C), "Alarm Response and Management." This section provides guidance and sets requirements for managing the rasponses to alarms that are the responsibility of Occupational Health and Safety (OHS). This practice is applicable to all members of the OHS. Area OHS managers shall ensure that all members of their organizations are aware of and adhere to this practice.

WHC-CM-4-12, Section 2.1, REV 0, "Radiological Problem Reporting Program." The purpose of this section is to provide a documented record of observed radiological problems, a mechanism for reporting these problems to management for action, a capability to track and monitor the progress of the planned corrective actions, and a database for assessing trends in radiological program performance and needed actinns.

WHC-CM-4-12, Section 12.1, REV 1, "Emergency Response." An emergency is a sudden unexpected event requiring immediate response to mitigate impacts to people, property, or the environment. When radioactive material is involved, Health Physics (HP) plays a major role in evaluating, controlling, and recovering from the event. To be able to perform this function, HP personnel receive training to respond to a variety of emergency situations. The HP procedures (WHC-IP-0692 [WHC 1991b] and WHC-CM-4-12) are written to provide guidelines to respond to emergencies. Together, the training and the written procedures detall the HP emergency response program.

The HP personnel, in many situations, are the first to respond to a radiological emergency. The ability to assess and evaluate the situation and take immediate steps to minimize the effects of the event is crucial for controlling the emergency. The HP personnel use their training and experience to make decisions during the initial response to an emergency.

An emergency response may be initiated by (1) personnel observing the event, (2) alarms, (3) the Patrol Operation Center, or (4) the Emergency Control Center(s) once they are manned. The type of emergency determines the level of planning for HP response. For a planned response, HP personnel sliall be in teams of at least two. Out of necessity (e.g., backshift responrs), one member could be an operations person or other emergency service person, such as a 
firefighter or patrol. If a rapid response is required, no undue risks should be taken nor should personnel safety be compromised. When an emergency causes a facility evacuation, preplanning (e.g., stay time, entry route) and approval of the Building or Facility Emergency Director is necessary to re-enter.

Although HP personnel respond to an emergency using basic guidelines, an area or facility may have specific procedures that have priority over these guidelines.

WHC-IP-0692, Section 5.2.2.6, REV 2, "Gaseous Effluent Sampling and Monitoring System Operability Inspection." This procedure estaplishes the method of inspection, evaluation, and discrepancy reporting of the operational status of Gaseous Effluent Monitoring Systems (Stack Packs) in use in the 200 East and West Areas.

WHC-IP-0692, Section 5.2.2.7, REV 2, "Operation of Gaseous Effluent Sampling and Monitoring Systems." This procedure establishes the standard method of operation of Gaseous Effluent Sampling and Monitoring Systems (Generic Stack Packs) in use in the 200 East and West Areas.

WHC-IP-0692, Procedure No. 12.1.2.3, REV 2, "Effluent Exhaust CAM Alarm Response." This procedure establishes the standard method of handling samples from, and response to, alarms at effluent exhaust continuous air monitor systems in an expedited fashion.

WHC-IP-0263-BPC, REV 0, "Emergency Response Plans" (WHC 1992a). This procedure establishes guidelines for actions to be taken if $B$ Plant discharges highly radioactive gaseous material.

WHC-IP-0692, Procedure No. 12.2.1, REV 2, "Emergency Response Air Sampling." This procedure describes the guidelines and steps for emergency air sampling inside and outside factlities when a release of radioactive material is suspected.

WHC-IP-0692, Section 12.2.3, REV 0, "Health Physics Emergency Response Team." This procedure provides the organizational structure of, the instructions for, and the responsibilities of the HP Emergency Response Team (ERT) and the HP Technicians Field Survey Teams. These teams may be requested to respond to an emergency when an environmental release of radioactive material may extend beyond the control of a facility or outside the Hanford Site boundaries. These teams will have monitoring responsibilities only outside the boundaries of the event site.

WHC-IP-0692, Section 12.2.4, REV 2, "Emergency Radioactive Plume Tracking." This procedure establishes the instructions to track a beta-gamma plume created from a radioactive material release to the en: Ironment and determine if it is at ground level or at an elevated leve'.

Notifications and reporting of specific events related to environmental releases and/or events involving effluents and/or hazardcus materials are reported via instruction given in 
WHC-CM-7-5, Environmental Compli ance Manual, and WHC-IP-C263-BPC, Building Emergency Plan for B Plant Complex. The purpose of these manuals and sections is to establish and implement specific criteria and requirements for the identification, categorization, notification, and reporting of occurrences at $B$ Plant, as required by WHC-CM-1-3, MRP 5.14, "Occurrence Reporting and Processing of Operational Information."

4.3 The sample collection and analysis procedures used in measuring the emissions shall be described including there appl icable:

4.3.1 Identification of sampling sites and number of sampling points, including the rationsle for site selections.

The 291-B-1 Stack has an ID of 6.5 feet at the probe location, approximately 50 feet from the base. (The ID ranges from 7 feet at that base of the stack, to 5 feet at the top, 200 feet above the base.) There are twelve nozzles for sampling at the probe location; six nozzles supply the record sampler and the remaining six nozzles supply the beta-gamma monitor.

ANSI N13.1-1969 (Section A3.2) recommends a minimum of six nozzles on a stack the diameter of the 291-B-1 Stack (WHC 1991d).

The procedure in 40 CFR 61 , Appendix A, Method 1, requires sampling to be performed at least eight stack diameters downstream and two diameters upstream of any flow disturbances. Eight stack diameters corresponds to 52 feet and two stack diameters corresponds to 13 feet, based on the 6.5-foot diameter at the sampling location. As shown in the drawings and documentation listed in WHC (1991d), the 291-B-1 Stack complies with this procedure (WHC 1991d).

4.3.2 A description of sampling probes and representativeness of the samples.

The sampling probe consists of twelve total nozzles, as shown on Drawing H-2-94159 (WHC 1991d). Six nozzle inlets are $0.348 \pm 0.002$ inches and the other six are $0.250 \pm 0.002$ inches in diameter. The stack flov: is fully turbulent (Reynolds number approximately $6.8 \times 10^{5}$ ) and, as stated in Section A.3.3.2 of ANSI N13.1-1969, "... as the flow becomes more turbulent, the velocity becomes more nearly uniform across the duct." Therefore, the probe assembly is nearly isokinetic, as it was designed (see Note 4, Drawing H-2-94159 [WHC 1991d]).

4.3.3 A description of any continuous monitoring systems used to measure emissions, including the sensitivity of the system, calibration procedures and frequency of calibration.

Not applicable; emissions are not monitored continuously. 
WHC-EP-0536-1

4.3.4 A description of the sample collection systems for each redionuclide masured including frequency of collection, callibration procedures and frequency of calibration.

Particulate radionuclides are collected with the record sampler, which uses $47-\mathrm{mm}$ diameter filter paper. This filter is a membrane filter which collects $0.3-\mu \mathrm{m}$ particles with a collection efficiency of 95.8 percent. Record samplers are removed weekly and the sampler runs continuously to ensure a representative sample (WHC 1991a).

4.3.5 A description of the laboratory analysis proceduras used for each radionuclide measured, including frequency of analysis callibration procedures and frequency of calibration.

Total alpha and total beta activity is determined by procedure LA-508-110 or LA-508-114 on weekly samples, and occasionally on daily air samples, per collection point. The calibration procedure is documented in LQ-508-002. It is done only when deemed necessary by a responsible scientist. The counting system is recalibrated only in case of (1) major repairs or adjustments to the power supply or detector or (2) calibration shift as indicated by the instrument control standards. The performance of the counting systems is checked by running the instrument control standards $\left({ }^{147} \mathrm{Pm}\right.$ for low-energy beta, ${ }^{80} \mathrm{Co}_{0}$ for mid-energy beta, ${ }^{37}$ Cs for high-energy beta, and ${ }^{24} \mathrm{Am}$ for alpha activity) separately. When a batch of air filter samples is run, all the performance standards and the background (for counting frequency refer to LA-150-115) also are run with it. To verify that the counting system is working properly, the standard values from analysis should fall within the administrative limits set according to appropriate quality assurance program plans (QAPP).

The 222-S Laboratory method for analys is of alpha emitters ( ${ }^{241} \mathrm{Am},{ }^{238} \mathrm{Pu}$, and $239,240 \mathrm{Pu}$ ) involves various steps (LA-549-112 for dissolution, LA-943-123 for chemical separation, LA-542-101 for electrodeposition, and LA-508-051 for final alpha spectrometry). The analys is of alpha emitters is done on a quarterly composite of weekly and daily air filter samples. The energy resolution and calibration of the AEA system over the energy range of 4 to $6 \mathrm{MeV}$ are checked once a month by the Preventive Maintenance Procedure 2S18006. Efficiency calibration of the AEA is not needed in our analys is method because djrect comparison of the sample with recoveries of the tracers $\left({ }^{243} \mathrm{Am}\right.$ and $\left.{ }^{236} \mathrm{Pu}\right)$ is made to determine the activities of the radionuclides present in the sample. To carry out the sample analysis, AEA system performance is checked once every 24 hours for alpha energy shift with a certified mixed alpha source standard. Each alpha energy peak identified in the standard must fall within administratively assigned certain channels $(+10)$ on the MCA. For counting frequency of performance check standards, procedure LA-150-115 is referred to. The recovery of the radionuclides and the calibration of the system are checked on a batch basis by running a method standard under the identical conditions as the sample. 
The 222-S Laboratory method for determining beta activity $\left({ }^{89} \mathrm{Sr},{ }^{90} \mathrm{Sr} /{ }^{90} \mathrm{Y}\right.$ ) consists of dissolution (LA-549-112), chemical separation (LA-220-103), and total beta counting (LA-508-111). Analysis is done on a quarterly composite of weakly and dally air filter samples per collection point. The callbration procedure LQ-508-002 (for a window-type gas flow proportional counter) is used in conjunction with procedure LQ-508-005 (for mother/daughter case, 1.e., ${ }^{90} \mathrm{Sr} /{ }^{90} \mathrm{Y}$ in growth calibration). It is performed only when the responsible scientist finds it necessary. The reasons are the same as stated for total alpha and total beta. The performance of the counting system is checked once per shift by running instrument control standards ( ${ }^{60} \mathrm{Co},{ }^{3} \mathrm{Cs}$, and ${ }^{14} \mathrm{Pm}$ for beta activity). The complete procedure for the ${ }^{90} \mathrm{Sr} /{ }^{90} \mathrm{Y}$ analys is in the sample is carried out with a method standard (several filter papers spiked with ${ }^{90} \mathrm{Sr}$, ${ }^{44} \mathrm{Pm},{ }^{60} \mathrm{Co},{ }^{241} \mathrm{Am},{ }^{239} \mathrm{Pu}$, and U) provided by the 222-SA Standard Laboratory on a batch basis. This checks the overall performance of our method. The chemical yield is determined by using the appropriate carrier.

Determination of beta activity $\left({ }^{147} \mathrm{Pm},{ }^{14} \mathrm{C}\right.$, and $\left.{ }^{3} \mathrm{H}\right)$ involves

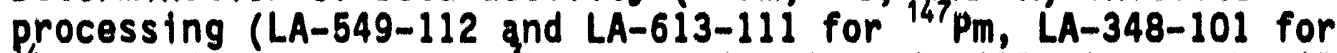
${ }^{4} \mathrm{C}$, and $L A-218-112$ for $\left.{ }^{3} \mathrm{H}\right)$, mounting in scint ${ }^{4} 11$ ation cocktail (LA-508-111), and finally, liquid scintillation counting (LA-508-121). The ${ }^{4} \mathrm{Pm}$ analys is is done on quarterly composites of weekly and daliy air filter samples. The ${ }^{14} \mathrm{C}$ and ${ }^{3} \mathrm{H}$ analyses are done on biweekly gas samples. For calibration, the quality assurance (QA) section of procedure LA-508-121 is referenced. The calibration of the instrument is checked by the manufacturer's supplied sources $\left({ }^{14} \mathrm{C}\right.$ and $\left.{ }^{3} \mathrm{H}\right)$ and its software.

For ${ }^{147} \mathrm{Pm}$ analysis, the method standard is run once per quarter. The method standard is always run with a batch of samples for ${ }^{3} \mathrm{H}$ and ${ }^{14} \mathrm{C}$ analysis. The results of the method standard checks the overall performance, including the calibration of the counting system. The instrument calibration check is done a minimum of once a week (refer to LA-150-115).

For analysis of gamma emitters ${ }^{95} \mathrm{Nb},{ }^{95} \mathrm{Zr},{ }^{134} \mathrm{Cs},{ }^{137} \mathrm{Cs}$, and ${ }^{144} \mathrm{Ce}$ the procedure LA-508-052 is followed. Analys is is done on quarterly composites of weekly and daily air fjlter samples. For analys is of volatile radionuclides ( ${ }^{129} \mathrm{I},{ }^{131} \mathrm{I},{ }^{106} \mathrm{Rh} /{ }^{106} \mathrm{Ru}$, ${ }^{13} \mathrm{Sn},{ }^{125} \mathrm{Sb}$, and $\left.{ }^{183} \mathrm{Ru}\right)$ collected weekly on silver zeolite cartridge, the procedure LA-288-101 is used in conjunction with procedure LA-508-052. Calibration of the gamma ray spectrometer is done with the, icedure documented in LQ-508-003 using a (NIST tracea -) certified mixed gamma ray standard. It is carried out only when it is deemed necessary by a responsible scientist. To check efficiency and energy calibration dally, the performance of each detector of the GEA system over the whole energy range is done once every shift by running a mixed gamma standard consisting of ${ }^{241} \mathrm{Am}$ for low energy, ${ }^{13} \mathrm{Cs}$ for mid energy, and ${ }^{60} \mathrm{Co}$ for high energy. The results of each of these radionuclides should fall within the 
administrative limits set according to the appropriate QAPP to continue analysis of samples. The dally performance results are documented. Minor adjustments of the electronics (e.g., fine gain, pole zero of the ampliffers, lower level discriminator of analog-to-digital converter) are done from time to time when necessary for proper energy calibration. Whenever a minor electronic adjustment is done on a detector, it is followed by analys is of a performance standard. For a major shift in the caltbration, the system is then thoroughiy calibrated using LQ-508-003.

The content of the 222-S Laboratory's procedures, test plans, supporting documents, and drawings provide a suffictent level of detal1 to allow trained personnel to produce quality results safely. Laboratory procedures are controlled as required by WHC-CM-5-4, Section 5.4, "Analytical Laboratory Procedures." The specific content of laboratory procedures is defined by its author, based on accepted methods such as 40 CFR 61, Appendix $B$, Method 114 (EPA 1991). The content must be agreed to by the peer and technical revlewers. While authors are responsible for the specific content of their procedures, they address the topics below.

SUmmary--MANDATORY--A short description or abstract of the procedure containing enough information to distinguish it from other procedures.

Applications--MANDATORY--Defines the scope and purpose of the specific procedure. This section may be combined with the following element under the title "Applications and Limitations."

Limitations--MANDATORY--Briefly describes those areas in which the procedure is not applicable. A statement of accuracy and prectsion will be given where appropriate.

Quality Control (OC) Protocol--Procedures used to support environmental projects that have specific QC requirements. For these procedures, the source of the QC requirement:s will be identified. The samples or project that this element applies to will be identified. The following information is typical of QC requirements: frequency and type of calibration, reagent blank analysis, spike sample analysis, and duplicate sample analysis.

Impact Level Ident ifier--MANDATORY--An impact level will be identified for each procedure following WHC-CM-1-3, MRP 5.43, with a brief basis of determination statement. This MRP 1ists several descriptive paragraphs delineating what constitutes an Impact Level 1, 2, 3, or 4 activity. The following parts of MRP 5.43 cover most analytical laboratory procedures.

1. Section 5, paragraph 6, part c., Impact Level 3 -- Work authorization documentation associated with work involving occupational hazards not covered by approved procedure, 
such as Operational Safoty Assessments, Radiation Work Permits, or Industrial Safety Standards.

2. Section 5, paragraph 6, part c., Impact Leve1 4 -Documentation for any activity not classed as Impact Level 1, 2, or 3.

The laboratories' procedures are usually specific to one activity. These activities are well defined using common scientific instrumentation and equipment operated in an acceptable manner. The chemicals and materials used are normally small quantities with limited potential for environmental or personnel safety impact. In general, the equipment used in the laboratory is not classified as Safety class 3 or higher.

Safety--MANDATORY--The procedure must identify applicable safety hazards.

The following documents identify Hanford Site safety requirements:

- WHC-CM-4-3, Volume 1-3, Industrial Safety

- WHC-CM-4-10, Radiation Protection

- WHC-CM-4-15, Radiation Work Requirements and Work Permits Manual

- WHC-CM-4-29, Nuclear Criticality Safety.

Supporting document WHC-SD-CP-LB-003, Safety in the Analytical Laboratory, is the laboratory general safety document. The authors must review safety requirements and include safety warnings appropriate to the actions directed by the procedure.

Beagents--If the procedure requires analytical reagents, a 1 ist of reagents will be provided. This material safety data sheet number will be placed in brackets by each chemical name.

Reagent makeup, storage container requirements, unique storage needs, shelf-iffe requirements, special labeling, and special preparation steps will be included. Spectal notations for any known or suspected carcinogen as listed on WHC-CM-4-3, Volume 2, Table 1, "WHC Master Carcinogen List," W111 be made on the reagent 1 ist.

Reagent preparation described fully in other current Hanford site documentation may be included by reference.

Equipment--Special equipment needs will be listed. Standard hood or glovebox equipment is assumed to be available at the work station and does not need to be listed. The fabrication of off-standard equipment will be referenced or described in this section. 
Procedure Steps--MANDATORY--A step-by-step description of operations necessary to perform the task will be presented in a logical and sequentially numbered order or en assignment of responsibilitios. CAUTIONS and WARNINGS notations will be included for the applicable safety hazard before the action is described. Steps with potential for criticality specification violation will be identified. Explanatory "Notes" may be included for clarification of process.

Calculations--Calculations required to complete the work will be described in this section. Exampies with sample values may be included. All combined factors will be fully described and units noted.

Calibrations--When calibrations are required, a description of how to carry out required calfbrations will be given.

Discussion--A discussion of the theoretical aspects of the procedure. Brief identification of unique characteristics and interfaces to ald in troubleshooting may be included.

References--A reference list of published information to provide technical basis for the procedure may be included.

The mandatory topics are addressed in both procedures. However, the laboratories have technical, analytical, and administrative procedures. Nonmandatory topics are included if appropriate to the activity covered by the procedure.

The calibrations of all laboratory instruments are controlled by the Laboratory Instrument Calibration Control System (LICCS) (WHC-CM-5-4, Section 8.2). The LICCS documents the requirements for and the performance of calibration activities for each analytical instrument or measurement device.

4.3.6 A description of the sample flow rate measurement systems or procedures, including callibration procedures and frequency of callibration.

Three vacuum pumps draw atr through the sample transport lines. The two pumps associated with the beta and gamma monitor and backup record sampler operate at $2.0 \pm 0.2 \mathrm{ft}^{3} / \mathrm{min}$ while the record sampler operations at $3.0 \pm 0.2 \mathrm{ft}^{3} / \mathrm{min}$. A sample transport line extends from the probe mounting assembly to the monitoring instruments located in Building 292-B, approximately 40 feet from the base of the stack. Four tubes are bound together between the probes and the monitoring instrumentation: one each for the record sampler and the beta and gamma monitor and two tubes comprising the pitot tube assembly (which is discussed in the following section). The sample transport lines are heat traced and insulated to inhibit condensation and the resultant sample fiow retardation. The sample transport lines are installed with a minimum number of bends, using a minimum bend radius of ten times the tubing inside diameter. The sample air flows into the monitoring instrument assembly (WHC 1991d). 
Record Sampler:

The record sampler sample passes through a record sample fliter which collects offluent particulates on a 47-mm-dlamoter filter paper. The filter papers are exchanged weekly and evaluated for gross alpha and gross beta activities by laboratory analysis. The record samplers provide the basis for reporting the amount and concentration of radionuclides released to the environment. These reports are forwarded to all appropriate organizations and agencles. Downstream of the filter, the record sampler passes thro gh a flow meter, a flow totalizer, a flow regulator, and a vacuum pump. In the event of a low flow In the record sampler line, a local alarm and remote alarm are activated. The local al arm indicates a low record flow (and is connected to the beacon outside Building 292-B) and the remote alarm in the 271-B dispatchers office indicates a monitor fallure (WHC 1991d).

Beta-Gamma Sampler:

Within the monitoring instrumentation rack, the beta-gamma sample passes through a flow splitter and is divided into two parts: The first split passes through a beta-gamma continuous monitor equipped with both a local and a remote (271-B dispatcher's office) alarm. The monitor continuously monitors particulate matter bulldup on filter paper for the detection and measurement of beta and gamma radiation. The fllter paper is collected weekly and analyzed for gross beta and gamma readings. In the event of the radiation bulldup exceeding established parameters, a remote stack radiation indicator alarm is activated, as is a local high-beta radiation alarm. The local alarm is connected to both a bell and a bacon outside Bullding 292-B. After the monitor, the sample passes through a flow regulator and a vacuum pump. In the ovent of low fiow in the beta-gamma sample line, a local alarm and a remote alarm are activated. The local alarm indicates a low beta flow (and is connected to the beacon outside the 292-B building) and the remote alarm in the 271-B dispatcher's office indicates a monttor fallure.

The second split passes through a backup record sampler, which consists of a 47-mm-dlameter filter that collects the effluent particulates. After the filter, the split passes through a rotameter (flow meter), a flow regulator, and a vacuum pump. In the event of a low flow in the backup sampler line, a local alarm and a remote alarm are activated. The local alarm indicates low back-up record flow (and is connected to the beacon outside Building 292-B) and the remote alarm in the 271-B dispatcher's office indicates a monitor fallure (WHC 1991d). 
Calibration and inspection of the system are accomplished at the following intervals:

$\begin{array}{ll}\text { Procedure } & \text { Erequency } \\ \text { PROC 5.2.2.6 } & \text { Weekly } \\ \text { PSCP-3-002 } & \text { Monthiy } \\ \text { PSCP-4-007 } & 6 \text { Months } \\ \text { PSCP-4-091 } & 6 \text { Months } \\ \text { PSCP-6-029 } & 6 \text { Months } \\ \text { PSCP-7-001 } & 6 \text { Months }\end{array}$

Titles of these procedures are presented below:

Health Physics Procedure No. 5.2.2.6, Rev 2, Gaseous Effluent Samoling and Monitoring Systom Oporab llity Inspection

Maintenance Engineering Services Calibration Procedure PSCP-3-002, Eberl ine Bota Air Monttor. Models AMS-3. AMS-3A. and 700300

Maintenance Engineering Services Calibration Procedure PSCP-1-007, Beckwell Type Gas Meter

Maintenance Englneering Services Calibration Procedure PSCP-4-091, Pressure and Vacuum Gauges

Maintenance Engineering Services Calibration Procedure PSCP-6-029, Chem-Tec Adjustable Flow Switch Medel 500

Maintenance Engineering Services Calibration Procedure PSCP-7-001, Air Rotameter

4.3.7 A deseription of the offluent flow rate meseurement procedures, including frequency of measurements, calibretion procedures and frequency of callibration.

The flow rate is measured continuously. The pitot tube assembly is comprised of two tubes that measure the static and total pressure in the stack air space, from which the flow rate can be determined and sent to the Facility Process Monitor Control System (FPMCS) by a flow transmitter. In the 271-B dispatchers office, stack flow rate is displayed and trended by the FPMCS (WHC 199id).

The calibration and inspection is performed every 6 months using Maintenance Engineering Services Calibration Procedure PSCP-6-032, Bailey Electronic DP Transmittor Type BCX Series. 


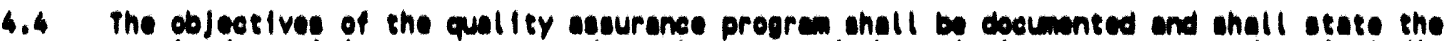

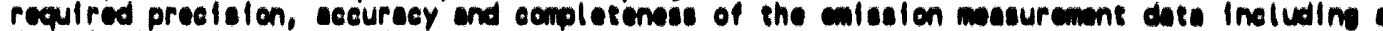

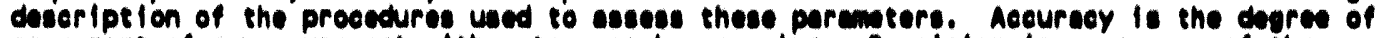
ogruement of a mesurement with a true or known valus. Precteion is a mosure of the agrement anong individual masurements of the acme parcmeters under simller conditions. completeness 18 a meseure of the enount of date obtalned compared to the curount expeted under normal conditions.

The accuracy of all analyses is checked using percent recovery. The evaluation of blind or known check standards provides the percent recovery.

For both blind and known check standards, percent recovery is calculated by the following equation:

$$
P=100 \cdot \frac{R}{S_{t}}
$$

Where:

$P$ - Percent recovory

R - Measured or recovered analyte concentration in the check standard

$S_{t}$ - Concentration of analyte in the check standard.

The laboratories do not use manual H. A. Showhart control charts (Shewhart 1931). The Laboratory Measurement Control System (LMCS) is a software package designed for support of management quality control decisions. Each analytical moasurement system has different control parameter requirements based on the use of specific standards. The LMCS program provide a performance versus 1 imits control chart for each standard. The average percent recovery (P) or 100 percent, depending on the method, marks the center of the 1 imit. The upper and lower boundartes of the limits are multiples of the standard deviation ( $s$ ) of the average percent recovery. The laboratory manager approves the LMCS limits, dofined as $P \pm n s$, where $n$ is a positive number. The values for $p$ and $s$ are elther performance based or set administratively. In general, laboratory management sets the warning 11 imits at $2 s$ and the control 1 imits at 3s or their equivalent.

When the LMCS identifies an out-of-control mothod, it automatically initiates corrective action. The system issues an off-standard Condition Report (OSCR). The sclentist in charge of the method must discover and resolve the problem to close out the OSCR. Until the OSCR has been clear, personnel can not perform any analyses by this method. After the sclentist has resolved the problem, personnel evaluate all analyses performed since the last in-control point. 
The laboratorles assess preciston by examining the results from split samples or laboratory dupl leates. Pereont rolative difference measures the prectsion of analyses. Percent relative difference is computed by the following equation:

$$
R D=100 \cdot \frac{s_{d}}{X}
$$

Whare:

RD - Percent relative difference

$S_{\mathrm{g}}$ - The standard deviation estimate of the duplicate data set 8 - The arfthmetic moan (average) of the duplicate data set.

The Initial QA objective for completeness of analyses in the laboratorles is 90 percont. This moans that the goal is to produce usable analytical data for a minimum of 90 percent of the analyses requested on all samples submitted to the laboratory. The laboratory ovaluates actual performance agalnst the 90 -percent objective. If the laboratory performance drops below this 11 intt, iaboratory management initlates corrective action. This action shall Identify and correct those activities within the laboratory that have caused the drop in performance. The objectives are documented in the Environmental Protection Quality Assurance Project Plan (QAPJP) (WHC 1992d).

4.5 A quality control progrem thall be establlahed to evoluste and treck the qualley of the

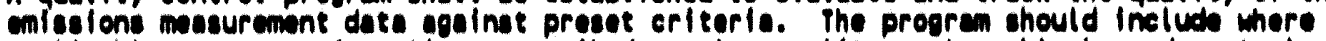
apol lcable aystem of repl leates, aplked semples, split sumples, blanks end control cheres. The number and frequeney of such qualley control checke shall be identifled.

The samples analyzed under this program consist of mounts made from preparation of stack fliters. Each sample collection point produces only one sample which is sent to the laboratory for analys is. No replicate samples are avallable. Repeat mossurement of Individual samples are made at the discretion of the scientist in charge.

As a type of process control samples, stack fllters are not subject to matrix effects and radjonuclide spikes are not used ${ }_{261}$ Howaygr, tracer glements ${ }^{263} \mathrm{Am}$ and ${ }^{236} \mathrm{Pu}$ support the analys is of $261 \mathrm{Am},{ }^{23 \mathrm{Pu}^{\mathrm{P}}}$, and $239,240 \mathrm{Pu}$ in the quarterly composite of weekly filter samples.

The laboratory does not split samples. There is no guarantee that the distribution of material on the filter will be homogenous. Because of this, no subsampling procedure, such as splitting, can be assured of producling two representative portions. Also, spiftting the sample in effect dllutes the sample, which would adversely effect the method detection limits.

Formal blanks are not avallable for this analys 1s. However, prior to the analysis of a batch of samples, the background of the counting instrument is chockeo. This backgl ound chock is rade on each planchet and planchet holder. 
Control charts and standards used in support of this analysis are deseribed in section 4.4 above.

4.6 A semple tracking eystem shall be establlahed to provlde for positive Identifleatlon of cemples and date through all phases of the semple collection, enolvals and reporting evetem. semple hendiling and preservation procedures whall be eatabllohed to maintain the integrlty of cemples during collection, storage and analyols.

Seo section 6.2.3 of WHC-EP-0536 (WHC 1991C).

4.7 Perlodle internal and external audits ahall be parformed to monitor compllance with the qualley asourence progrem. These audits tholl be performed in aceordance with written procedures and conducted by personnel tho de not have reapenalbilltey for performing any of the operations beling oudled.

See Section 7.0 of WHC-EP-0536.

4.8 A corrective action progran shall be eatabllahed Including erlterlo for men corrective actlon 1. meeded, that corrective ection will be taken and whe ls responsible for taking the corrective action.

See Section 8.0 of WHC-EP-0536.

4.9 Perlodic reports to responalble management shall be prepared on the performanee of the conlestons meseuremente progrem. These roporte should include sesesement of the quallty of the date, results of acdite and deseription of corrective netions.

See Section 9.0 of WHC-EP-0536.

4.10 The qualley aseurance progrem should bo doeumented in a qullity sesurance prolect plen which should addrese esch of the above requirements.

The QA Program addressing Stack 291-8-1 w111 be documented in a future QAPJP. 


\section{REFERENCES}

DOE, 1990, Radiation Protection of the Public and the Environment, DOE Order 5400.5, U.S. Department of Energy, Washington, D.C.

EPA, 1989, 40 CFR 60, "Standards of Performance of New Stat lonary Sources," Title 40, Code for Federal Regulations, Part 60 , as amended,

U.S. Environmental Protection Agency, Washington, D.C.

EPA, 1991, 40 CFR 61, Append1X B, Method 114, U.S. Environmental Protection Agency, Washington, D.C.

Napler, B. A., R. A. Peloquin, D. L. Strenge, and J. V. Ramsdell, 1988, GENII - The Hanford Environmental Radiation Dosimetry Software system, PNL-6584, Vols. 1-3, Pacific Northwest Laboratory, Richland, Washington.

Shewhart, 1931, Economic Control of Quality of Manufactured Product, Van Nostrand, New York City, New York.

RL, 1991, Calendar Year 1990 Air Emissions Report for the Hanford site, RL-91-10, U.S. Department of Energy-Richland Operations Office, Richland, Washington.

WHC, 1991a, Facility Effluent Monitoring Plan for the B Plant, WHC-EP-0467, Westinghouse Hanford Company, Richland, Washington.

WHC, 1991b, Health Physics Procedure Manual, WHC-IP-0692, Westinghouse Hanford Company, Richland, Washington.

- Procedure 5.2.2.6, Rev 2, "Gaseous Effluent Sampling and Monitoring System Operability Inspection."

WHC, 1991c, Quality Assurance Program Plan for Radionuclide Airborne Emissions Monitoring, WHC-EP-0536, Westinghouse Hanford Company, Richland, Washington.

WHC, 1991d, Drawings, Westinghouse Hanford Company, Richland, Washington.

- H-2-91208, Generic Stack Beta Record Rack Assembly

- H-2-92488, Generic Stack Sampler/Monitor modifled Monitor Assembly

- H-2-92489, Generic Stack Sampler/Monitor Record Sample Loop Assembly

- H-2-92490, Generic Stack Sampler/Monitor Sample Extraction Assembly

- H-2-92514, Differential Pressure Transmitter and Manifold Assembly

- H-2-94158, Elect/Instm/Owg List site Plan and Detalls, 291-8-1 Sampler/Monitor

- H-2-94ij9, Probe Assembly 291-8-1 Stack Sampler/Monitor

- H-2-96550, IEFD B Plant Area Stack Monitors 291-8-1

- W-69512, 291-8-T-U Concrete Stack Foundation Detalls

- W-73544, 221 T-U-B Concrete Ducts and Pits, Plans and Detalls

- HW-72051, Building No. 291 T, U, B Ventilation Exhaust Units Arrangement

- W-72438, Building No. 29! T-U-B Ventilation Exhaust Stack Breeching Arrangement 


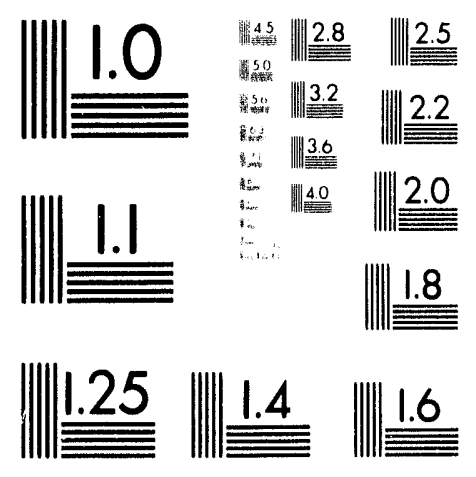



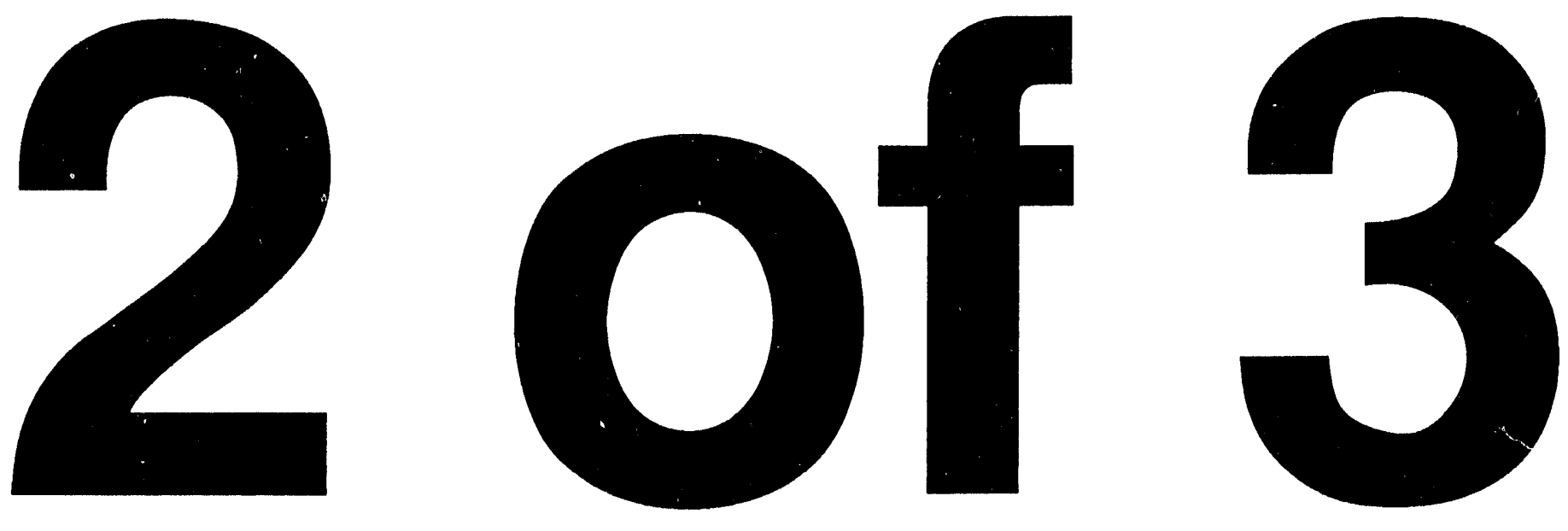
- ES-BPF-70174, Reinforced Concrete Chimney Lined Process Stack Eq PC 291-B-C-T-U-901 (Note: This drawing represents a condensed recreation of the original Rust Engineering blue print file 70174 of July 10, 1943. The original contract called for four tapered reinforced concrete stacks, circular in section, with acid proof brick lining. Stacks to be 200 '0" above foundations - inside diameter at top 5'0". Hole drilled in concrete column adjacent to ladder at a point 50'0" above top of foundation.)

WHC, 1992a, Building Emergency Plan for B Plant Complex, WHC-IP-0263-BCP, Westinghouse Hanford Company, Richland, Washington.

WHC, 1992b, Laboratory Procedures, Westinghouse Hanford Company, Richland, Washington.

- LA-150-115, Instrument Standards Counting Frequency--222-S Counting Room

- LA-218-112, Instrument Standards Counting Frequencs--222-S Counting Room

- LA-220-103, strontium-89, 90 and/or strontium-89 and 90 from Leachates of Soil, Vegetation, Air Filters, and Other Solid Samples

- LA-288-101, Gamma Analysis of Silver Zeolite Cartridges in the 222-S Counting Room

- LA-348-101, Carbon-14 by Distilling and Liquid Scintillation Counting

- LA-508-051, Alpha Energy Analysis using the Canberra Jupiter Systems

- LA-508-052, Gamma Energy Analysis on the Canberra Jupiter System

- LA-508-110, Operation of the Tennelec LB-5500 Alpha/Beta Counting System

- LA-508-111, Operation of the Tennelec LB-1000 Alpha/Beta Detectors $(9,10,11$, and 12$)$

- LA-508-114, Operation of the gamma products alpha beta counting system using $P C$ control

- LA-508-121, Operation of the Beckman Liquid Scintillation Counters

- LA-542-101, Electrodeposition of Actinides

- LA-548-111, Preparation of Mounts for Liquid Scintillation Counting

- LA-549-112, Dissolution of Versapor Type Filers

- LA-613-111, Determination of Promethium-147 in Effluent Wastes Samples by Solvent Extraction and Liquid Scintillation Counting

- LA-925-107, Uranium by Laser Induced Kinetic Phosphorescence Analyzer

- LA-943-123, Separation of Pu and Am by Ion Exchange,

- L0-150-133, Processing Record Stack and Red Bordered Emergency Air Samples

- LQ-508-002, Calibration Guidelines for Window Type Gas Flow Alpha/Beta Proportional Counters

- LQ-508-003, Calibration of the Jupiter Gamma Energy Analysis Systems

- LQ-508-005, Calibration of Beta Detector for Sr-90 and Y-90

- WHC-SD-CP-LB-003, Safety in the Analytical Laboratory 
WHC, 1992c, Manuals, Westinghouse Hanford Company, Richland, Washington.

- WHC-CM-1-3, Management Requirements and Procedures

- WHC-CM-4-1, Emergency Plan

- WHC-CM-4-2, Quality Assurance Manual

- WHC-CM-4-3, Industrial Safety

- WHC-CM-4-10, Radiation Protection

- WHC-CM-4-12, Health Physics Practices Manual

- WHC-CM-4-15, Radiation Work Requirements and Work Permits Manual

- WHC-CM-4-29, Nuclear Criticality Safety

- WHC-CM-4-43, Emergency Management Procedures

- WHC-CM-4-44, Emergency Preparedness Administrative Manual

- WHC-CM-5-4, Analytical Chemistry Services Laboratories - Operating Instructions

- WHC-CM-7-5, Environmental Compliance Manual

WHC, 1992d, Quality Assurance Project Plan for Radioactive Airborne Emissions Data Compilation and Reporting, WHC-EP-0528, Westinghouse Hanford Company, Richland, Washington. 


\section{WHC-EP-0536-1}

\section{APPENDIX C}

\section{METHOD 114 COMPARISON FOR STACK 291-Z-1}

J. G. Kristofzski and D. Alison 
WHC-EP-0536-1

This page intentionally left blank. 


\section{APPENDIX 6 \\ METHOD 114 COMPARISON FOR STACK 291-Z-1}

This section provides a line-by-line evaluation of quality assurance method requirements outlined in 40 CFR 61, Appendix B, Method 114, as they apply to the 291-Z-1 stack at the Plutonium Finishing Plant (PFP), Hanford Site.

METHOD 114-TEST METHOOS FOR MEASURINO

RADIONUCLIDE EMISSIONS FROM STATIONARY SOURCES

\subsection{Pucsose and Backoround}

This method provides the requirements for: (1) stack monitoring and semple collectlon mathods appropriate for redionuclldes; (2) rediochemical mathods thich are used in determining the cmounte of radionucl ides collected by the stack sempling and; (3) quality assurance methods which ere conducted in conjunction with these mesurements. These methods are appropriate for eniesions for statlonary sources. A lise of references le provided.

Meny different types of facillties relese radionuclides into oir. These redionuclides diffor in the chemical and phyeical forme, half-lives and type of radiation emitted. The appropriate combination of sanple extraction, collection and anclyele for an Individual radionuclide is dependent upon many interrelated factors including the mixture of other radionuclides present. Becouse of this wide range of conditions, no single method for monitoring or sample collection and analysis of a redionuclide ls applicable to all types of facillities. Therefore, series of methods based on "principles of measurement" are described for monitoring and sample collection and analysis which are applicable to the measurement of radionucllides found in affluent sereams at stationary sources. This approech provides the user with the flexibility to choose the most appropriate combination of monitoring and sample collection and anaiysis methods which are applicable to the effluent strean to be masured.

\subsection{Steck Monitoring and Samole Coilection Methods}

Monitoring and semple collection methods ure described besed on "principles of monitoring and sample collaction" which are applicable to the mesurement of redionuclides from efflluent strecens ot etetionary sources. Radionuclides of most elements wi!l be In the particulate form in these effluent stream and can be readily collected using sultable fllter madia. Radionucllaes of hydrogen, oxygen, carbon, nitrogen, the noble gases and in some circumatances lodine will be in the gaseous form. Redionuclides of these - lements will require either the use of an in-line or off-line monitor to directly measure the radionuclides, or suitable sorbers, condensers or bubblers to collect the radionuclides.

2.1 Radionuclides as Particulates. The extracted effluent atream is passed through a filter madia to remove the particulates. The filter must have a high efficlency for removal of sub-micron particles. The guidance in ANSI N13.1-1969 shall be followed in using filler media to collect particulates

(incorporated by reference-see \$61.18).

The filter media used to remove the particulates is a $47-\mathrm{mm}$ Versapor* 3000 or equivalent air sample fliter as described by WHC-CM-4-13, Section 5.5.5.7, REV 2.

\subsection{Radionuclides as Gases.}

The 291-z-1 stack does not exhaust radionuclide gases; therefore, this section is not applicable to this stack.

*Trademark of Gelman Sciences, Inc. 
WHC-EP-0536-1

\subsection{Definition of Term}

No response requitred.

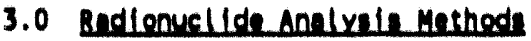

The analysis methods have been evaluated by the 222-S Laboratory cognizant personnel and are included as Appendix $G$.

\section{0 gundley Amsurence Method}

Each facllity required to measure thelr radionuclide emilestone shall conduct a quall ty aseurence progrem in conjunction with the redlonuclide emlesion measurements. ihlo program shall aseure that the emisolon measuremente are representative, and are of known precision and eccuracy and sholl include edninletrative controls to assure prompt response when emiseion moseuremente ind lcete unexpectedly large misulons. The progrem shall consist of system of pollcles, orgentzational responsibfllties, written procedures, date quality speclfications, audits, corrective ections and reports. Thls quallity aseurance progran shall include the following progrem elemente:

4.1 The organizational structure functional leapons lbllities, levels of authority and lines of comminications for all ectivitles rolated to the emiselons meseurement progrem shall be identifled and documented.

4.2 Acministrative controls shall be preseribed to ensure prompt response in the event that emiselon levels increase due to unplanned operations.

WHC-CM-4-1, REV 1, Emergency Plan. This manual contains an omergency preparedness plan to protect onsite personnel, public health and safety, and the environment in the event of operation, natural phenomena, and/or safeguards and security ovents at Westinghouse Hanford Company (Westinghouse Hanford) facllities. The requirements stated in the emergency preparodness plan are Implemented through subtior plans and implementing procedures. These implementing plans and procedures established for response to emergencies by West inghouse Hanford personnel and emergency management organizations are contained in WHC-CM-4-43, Emergency Management Procedures; WHC-CM-4-44, Emergency Preparedness Administrative Manual; varlous bullding emergency plans; and Westinghouse Hanford facility operating procedures (WHC-IP-0263-PFP).

WHC-CM-4-12, Section 1.14, REV 0, "Alarm Response and Management." This section provides guldance and sets requirements for managing the responses to alarms that are the responsibllity of occupational Health and Safety (OHS). This practice is applicable to all members of the OHS. Area OHS managers shall ensure that all members of their organizations are aware of and adhere to this practice.

WHC-CM-4-12, Section 2.1, REV 0, "Radiological Problem Reporting Program." The purpose of this section is to provide a documented record of observed radiological problems, a mechanism for reporting these problems to management for action, a capability to track and monitor the progress of the planned corrective actions, and a database for assessing trends in radiological program performance and needed actions. 
WHC-CM-4-12, Section 12.1, REV 1, "Emergency Response." An emergency is a sudden unexpected event requiring immediate response to mitigate impacts to people, property, or the environment. When radioactive material is involved, Health Physics (HP) plays a major role in evaluating, controlling, and recovering from the event. To be able to perform this function, HP personnel receive training to respond to a variety of emergency situations. The HP procedures (WHC-IP-0692 and WHC-CM-4-12) are written to provide guidelines to respond to emergencies. Together, the training and the written procedure detalf the HP emergency response program.

Emergency Response. The HP personnel, in many situations, are the first to respond to a radiological emergency. The abllity to assess and evaluate the situation and take immediate steps to minimize the effects of the event is cructal for controliting the emergency. The HP personnel use their training and experience to make decisions during the initial response to an emergency.

An emergency response may be initiated by (1) personnel observing the event, (2) alarms, (3) the Patrol Operation Center, or (4) the Emergency Control Center(s) once they are manned. The type of emergency determines the level of planning for HP response. For a planned response, HP personnel shall be in teams of at least two. Out of necessity (e.g., backshift response), one member could be an Operations person or other emergency service person such as a firefighter or patrol. If a rapid response is required, no undue risks should be taken nor should personnel safety be compromised. When an emergency causes a facility evacuation, preplanning (e.g., stay time, entry route, etc.) and approval of the Butlding or Facility Emergency Director is necessary to re-enter.

Although HP personnel respond to an emergency using basic guidelines, an area or facility may have specific procedures that have priority over these guidelines.

WHC-IP-0692, Section 12.1.2.6, REV 0, "HP Response to Room 221A \& Room 631 Annunclator Panel Alarms." This procedure provides the HP staff at PFP the information and required actions needed to respond to a radiation or contamination-related alarm.

WHC-IP-0692, Section 5.2.2.6, REV 2, "Gaseous Effluent Sampling and Monitoring System Operability Inspection." This procedure estab1 ishes the method of inspection, evaluation, and discrepancy reporting of the operational status of Gaseous Effluent Monitoring Systems (Stack Packs), in use in the 200 East and West Areas.

WHC-C.M-4-13, Section 5.2.2.7, REV 2, "Operation of Gaseous Effluent Sampling and Monitoring Systems." This procedure establishes the standard method of operation of Gaseous Effluent Sampling and Monitoring Systems (Generic Stack Packs) in use in the 200 East and West Areas. 
WHC-DI-33920-010, REV 0, Operation and Inspection of PFP Stack Sampling and Monitoring systems. This desk instruction provides PFP and stack-specific implementing procedures and references for the effluent sampling and monttoring systems including response to alarms.

WHC-CM-4-13, Procedure No. 12.1.2.3, REV 2, "Effluent Exhaust CAM Alarm Response." This procedure establishes the standard method of handling samples from, and response to alarms at, effluent exhaust continuous air monitor (CAM) systems in an expedited fashion.

WHC-IP-0263-PFP, Section 6.0, REV 2, "Emergency Response Plans." This procedure estabilishes gutdelines for actions to be taken if the PFP discharges highly radioactive gaseous materlal.

WHC-CM-5-8, Procedure 1.5, REV 2, "Non-Rout ine Release Response." This procedure detalls the response actions to non-routine releases as evidenced by high sample results from gaseous effluent samples at the PFP.

WHC-IP-0692, Procedure No. 12.2.1, REV 2, "Emergency Response A1r Sampling." This procedure describes the guidelines and steps for emergency air sampling inside and outstde factlities when a releaso of radioactive material is suspected.

WHC-IP-0692, Section 12.2.3, REV 0, "Health Physics Emergency Response Team." This procedure provides the organizational structure of, the instructions for, and the responsibilities of the HP Emergency Response Team and the HP Technicians Field Survey Teams. This procedure describes the steps for an initial emergency response by the HP Emergency Response Team and HP Technicians Fiold Survey Teams. The HP Emergency Response Team and the HP Technicians Field Survey Teams may be requested to respond to an emergency when an environmental release of radioactive material may extend beyond the control of a facility or outside the Hanford site boundaries. These teams will have monitoring responsibilities only outside the boundaries of the event site.

WHC-1P-0692, Section 12.2.4, REV 2, "Emergency Radioactive Plume Tracking." This procedure establishes the instructions to track a beta-gamma plume created from a radioactive material release to the environment and determine if it is at ground level or at an elevated level.

Notifications and reporting of specific events related to environmental releases and/or events involving effluents and/or hazardous materials are reported via instruction given in WHC-CM-7-5, Environmental Compliance Manual, and WHC-IP-0263-PFP, Building Emergency Plan fur. Plutonium Finishing Plant Complex Emergency Response Plans, Section 6.6, "Radioactive Materlals Response Plan." The purpose of these manuals and sections is to establish and implement specific criteria and requirements for the identification, categorization, notification, and reporting of occurrences at the 
WHC-EP-0536-1

PFP, as required by WHC-CM-1-3, MRP 5.14, "Occurrence Reporting and Processing of Operational Information."

4.3 The sample collection and anslyels procedures used in mesuring the emiseions shall be doscribed including where applicable:

4.3.1 Identiflcation of sampling sites and number of sempling points, including the rationale for site selections.

A continuous effluent sample is extracted from the 291-2-1 stack by a single probe located at the $15 \mathrm{~m}$ (50 ft) level of the stack. The stack diameter at this location is $15.75 \mathrm{ft}$. The nearest flow disturbances are at the inlet and outlet of the stack, approximately three stack diameters downstream and nine stack diameters upstream from the sampling location. The $15 \mathrm{~m}$ (50 ft) sampling location was selected after extenstve studies were performed. The presence of an existing penetration in the stack at this lovel was an important factor in sample site location as this suppiled Pacific Northwest Laboratory (PNL) an access point through which instrumentation could be inserted to study the effluent characteristics. The site was proven to be acceptable for sampling.

This sampling location meets the stack diameter requirements of 40 CFR 60, Method 1.

\subsubsection{A description of sampling probes and representativeness of the samples.}

The sampling probe consists of six nozzles branching from a single sample delivery line and is entirely of 300-series stainless steel (drawings $\mathrm{H}-2-28543$ and $\mathrm{H}-2-28545$ ). The collection probe spans the diameter of the stack with the nozzles centered in six equal annular areas. The bend radif of the collection tubes are 2.5 times the tube radius or 1.25 times the tube diameter. The sample delivery line increases in diameter as each branch 1 ine joins to keep the mass flow rate consistent with sample velocity. The probe delivers the sample to a 300-series stainless steel flow splitter for record and CAM samples.

The velocity distribution at the sampling site was measured before sampler construction. But as stated in ANSI N13.1-1969, "as the flow becomes more turbulent, the velocity becomes more nearly uniform across the duct." Therefore, velocity distribution is of lesser importance for the 291-Z-1 stack as the flow is highly turbulent (Reynolds Number $=2,000,000$ ). The flow rate for the 291-Z-1 stack varies only a few percent. The varlation in 1988 was determined to be only $3 \%$ and for 1991 a variation of $4.5 \%$ was observed. Given these facts, the sample probe provides the sample collection system with a representative, isokinetic sample. 
WHC-EP-0536-1

4.3.3 A description of any continuous monitoring system used to measure emissions, including the sensitivity of the system, callibration procedures and frequency of calibration.

Not applicable--emissions are not monitored continuousiy.

4.3.4 A description of the sample collection systems for each radionuclide masured, including frequency of collection, calibration procedures and frequency of callibration.

The sample collection probe extracts effluent from the stack at a flow rate of 4 std. ft $3 / \mathrm{min}^{2}$. The sampler probe uses six nozzles for sampling the stack flow (drawing $H-2-28545$ ). A sample transport line extends approximately $1 \mathrm{~m}$, horizontaliy, from the stack surface connection flange to the monitoring instruments located within an adjacent, elevated sample shack. The sample transport line is heated by a baseboard heater tmmediately below the line within the bullding to inhibit condensation of motsture and resultant sample flow retardation by maintaining the temperature above the dewpoint. The sample transport line was selected and installed to minimize particle loss attributed to gravity settling and turbulent impaction. The transport line length and tube transition severity of the sample transport line were minimized. The bend radil are 1.25 times the inside diameter of the collection tube. Once the extracted sample is delivered to radiation monitoring system instrumentation, the sample stream passes through a fiow splitter and is divided into two equal parts: the record sample 100p and the CAM loop.

Particulate radionuclides are collected with a record sampler. The record sampler collects the particulates on a 47-mm-diameter filter (Gelman Sclences, Versapor $3000,3 \mu \mathrm{m}$ or equivalent). This filter is a membrane filter composed of acrylic copolymer cast on a non-woven nylon substrate good for collecting $0.3-\mu \mathrm{m}$ size particles with a $91 \%$ collection efficiency in air applications. The record sampler provides a representation of the amount and concentrations of radioactive particulates being discharged. The record sampies provide the basis for reporting the amount and concentration of radionuclides released to the environment. The filter media is exchanged weekly and evaluated for gross alpha and gross beta activities by laboratory analysis. The filter media is then composited for quarterly analysis of specific radionuclide concentrations.

The CAM loop collects particulate matter in a similar fashion to that of the record sampler, but the CAM monitors for elevated radioactivity on the filter. This instrument provides process control and backup capability for the record sampler. The CAM is calibrated annually.

4.3.5 A description of the laboratory analys is procedures used for each radionuclide measured. including frequency of analys is calibration procedures and frequency of calibration.

Refer to Appendix G. 
4.3.6 A description of the sample flow rate mesurement systeme or procedures, including calibration procedures and frequency of callibration.

The sample flow rate is measured and regulated by instruments located downstream of the sample collection fllter and CAM. The record sample loop passes in turn through an integrating flow meter (totalizer), a sight flow indicator (rotameter), a vacuum pressure indicator, a vacuum switch, a flow regulator, and a vacuum pump. The flow rate regulator is provided to maintain a constant flow rate through the collection filter assembly to compensate for filterloading offects. Audible and visible alarms signals indicating low vacuum pressure are provided remotely in the HP office and the power control room (both constantly manned locations). The calibration procedures and frequencies are summarized in Table $\mathrm{C}-1$.

Table C-1. Calibration Procedures and Frequencies for Record Sampler (Sample Flow Measurement Devices).

\begin{tabular}{|c|c|c|c|}
\hline Component & Procedures & PISCES* & Frequency \\
\hline Vacuum gauge & $\begin{array}{c}P S C P-4-091 \\
7-G N-038\end{array}$ & $E 0004-2$ & 6 month \\
\hline Flow totalizer & $\begin{array}{c}\text { PSCP-4-007 } \\
7-G N-038\end{array}$ & E0005-1 & $\begin{array}{c}3 \text { month } \\
\text { Install/annual }\end{array}$ \\
\hline Rotameter & $\begin{array}{c}\text { PSCP-7-001 } \\
7-G N-038\end{array}$ & Y0016-C & 6 month \\
\hline Vacuum switch & $\begin{array}{c}\text { PSCP-6-011 } \\
7-G N-038\end{array}$ & $E 0005-2$ & 6 month \\
\hline
\end{tabular}

*WHC $-C M-8-2$

The CAM loop differs only in that the sight flow indicator is an integral part of the CAM itself and that there is no flow totalizer. All other flow measurements, regulations, and monitoring is identical to that of the record sampler loop. The calibration procedures and frequencies are summartzed in Table C-2. 
Table C-2. Calibration Procedures and Frequencies for Continuous Air Monitor Sampler (Sample Flow Measurement Devices).

\begin{tabular}{|c|c|c|c|}
\hline Component & Procedures & PISCES & Frequency \\
\hline Vacuum gauge & $\begin{array}{l}\text { PSCP-4-091 } \\
7-G N-038\end{array}$ & E0004-1 & 6 month \\
\hline $\begin{array}{l}\text { Continuous air } \\
\text { monitor/rotameter }\end{array}$ & PNL-MA-563 & & 6 month \\
\hline Vacuum switch & $\begin{array}{l}\text { PSCP-6-011 } \\
7-G N-038\end{array}$ & E0005-3 & 6 month \\
\hline
\end{tabular}

Independent vacuum pumps are provided for each loop of the system. Redundant vacuum systems are not furnished, but failure annunciation (low flow rates) is provided and checked periodically to demonstrate operability.

4.3.7 A description of the effluent flow rate measurement procedures, including frequency of measurements, calibration procectures and frequency of calibration.

The volumetric flow rate for the 291-Z-1 stack is determined by the summation of independent flow rates of five tributary effluent streams. The streams are independently measured in accordance with pre-approved procedure PFP-PAP-076, "Stack Flow Measurements, "which references the vent and balance procedure 7-GN-56. The measurement locations and methods do not strictly conform to the criteria of 40 CFR 60, "Methods." The flow rate is directly measured with a standard pitot tube. The measurement locations are very close to flow disturbances both upstream and downstream. The building ductwork design does not allow for alternatives. The flow rates are determined quarterly as the flow rate does not widely yary.

Plans to fully comply with measurement requirements are underway at this time. Site selection is to be based on the criteria of 40 CFR, Part 60, Appendix A, Method 1. If a continuous measurement system is install, it will be certified in accordance with 40 CFR, Part 60, Appendix $E$.

4.4 The objectives of the quality assurance program shall be documented and shall state the required precision, accuracy and completeness of the emission measurement data including a description of the procedures used to assess these parameters. Accuracy is the degree of agreement of a measurement with a true or known value. Precision is a measure of the agreement among individual measurements of the same parameters under similar conditions. Completeness is a measure of the amount of data obtained compared to the amount expected under normal conditions.

See Appendix G. 
4.5 A quality control program shall be established to evaluate and track the quality of the emissions measurement data against preset criteria. The program should Include where applicable a system of repl icates, spiked samples, spl it samples, blanks and control charts. The number and frequency of such quality control checks shall be identified.

\section{See Appendix G.}

4.6 A sample tracking system shall be established to provide for positive identification of semples and data through all phases of the semple collection, analysis and reporting system. Sample handling and preservation procedures sholl be established to maintain the integrity of samples during collection, storage and analysis.

\section{See Section 6.2 .3 of the main body of this document.}

4.7 Periodic internal and external audits shall be performed to monitor compliance with the quality assurance program. These audits shall be performed in accordance with written procedures and conducted by personnel who do not have responsibility for performing any of the operations being audited.

See Section 7.0 of the main body of this document.

4.8 A corrective action program shall be established including criteria for when corrective action is needed, what corrective action will be taken and who is responsible for taking the corrective action.

See Section 8.0 of the main body of this document.

4.9 Periodic reports to responsible management shall be prepared on the performance of the emissions measurements program. These reports should include assessment of the quality of the data, results of audits and description of corrective actions.

See Section 9.0 of the main body of this document.

4.10 The quality assurance program should be documented in a quality assurance project plan which should address each of the above requirements.

The quality assurance program addressing stack $291-2-1$ is documented in WHC-EP-0561, Quality Assurance Project Plan for the Radionuclide Airborne Emissions for the Plutonium Finishing Plant. This is supplemented by WHC-EP-0528, Quality Assurance Project Plan for Radioactive Airborne Emissions Data Compilation and Reporting. 


\section{REFERENCES}

40 CFR 60, "Standards of Performance of New Stationary Sources, "Title 40, Code for Federal Regulations, Part 60, as amended, U.S. Environmental Protection Agency, Washington, D.C.

40 CFR 61, "National Emission Standards for Hazardous Air Pollutants," Title 40, Code for Federal Regulations, Part 61, as amended, U.S. Environmental Protection Agency, Washington, D.C.

ANSI, 1969, Guide to Sampling Airborne Radioactive Materials in a Nuclear Facility, ANSI N13.1-1969, American National Standards Institute, New York, New York.

Drawing H-2-28543, Sample Probe Installation Arrangement, Westinghouse Hanford Company, Richland, Washington.

Drawing H-2-28545, Sample Probe Assembly, Westinghouse Hanford Company, Richland, Washington.

Maintenance Engineering Services, Rockwel1 Type Gas Meter, PSCP-4-007, Westinghouse Hanford Company, Richland, Washington.

Maintenance Engineering Services, Pressure and Vacuum Gauges, PJCP-4-091, Westinghouse Hanford Company, Richland, Washington.

Maintenance Engineering Services, Diaphragm-Operated Pressure Switches, PSCP-6-011, Westinghouse Hanford Company, Richland, Washington.

Maintenance Engineering Services, 1989, Calibration Procedure, Air Rotometer, PSCP-7-001, Rev. 1, Westinghouse Hanford Company, Richland, Washington.

PFP-PAP-076, Pre-approved Procedure, Vent \& Balance Quarterly Stack Flow Measurements, Rev. 0, 1991, Westinghouse Hanford Company, Richland, Washington.

Procedure 7-GN-038, Pisces Recalled Instrumentation Maintenance Activities, Westinghouse Company, Richland, Washington.

Procedure 7-GN-56, Airflow Capacity and Distribution Tests, Westinghouse Hanford Company, Richland, Washington.

WHC-CM-1-3, Management Requirements and Procedures, as amended, Westinghouse Hanford Company, Richland, Washington.

WHC-CM-4-1, REV 1, Emergency Plan, as amended, Westinghouse Hanford Company, Richland, Washington.

WHC-CM-4-12, Health Physics Practices Manual, as amended, Westinghouse Hanford Company, Richland, Washington.

WHC-CM-4-13, Health Physics Procedures Manual, as amended, Westinghouse Hanford Company, Richland, Washington. 
WHC-CM-5-8, Plutonium Finishing Plant Administration, as amended, Westinghouse Hanford Company, Richland, Washington.

WHC-CM-7-5, Environmental Compliance Manual, as amended, Westinghouse Hanford Company, Richland, Washington.

WHC-CM-4-43, Emergency Management Procedures, as amended, Westinghouse Hanford Company, Richland, Washington.

WHC-CM-4-44, Emergency Preparedness Administrative Manual, as amended, Westinghouse Hanford Company, Richland, Washington.

WHC-CM-8-2, 200 Area Support Service, as amended, Westinghouse Hanford Company, Richland, Washington.

WHC-DI-33920-010, REV 0, Operation and Inspection of PFP Stack Sampling and Monitoring Systems, Westinghouse Hanford Company, Richland, Washington.

WHC-EP-0528, Quality Assurance Project Plan for Radioactive Airborne Emissions Data Compilation and Reporting, J. M. Nickels, 1992.

WHC-EP-0561, Quality Assurance Project Flan for the Radionuclide Airborne Emissions for the Plutonium Finishing Plant, J. G. Kristofzski and D. Alison, 1992 .

WHC-IP-0263-PFP, Building Emergency Plan for Plutonium Finishing Plant Complex Emergency Response Plan, Westinghouse Hanford Company, Richland, Washington.

WHC-IP-0692, Westinghouse Hanford Health Physics Procedures Manual-All Areas, Westinghouse Hanford Company, Richland, Washington. 
WHC-EP-0536-1

This page intentionally left blank.

C-14 
WHC-EP-0536-1

APPENDIX D

METHOD 114 COMPARISON FOR STACK 296-A-22

G. M. Crumme1

D-1 
WHC-EP-0536-1

This page irtentionally left blank. 
APPENDIX D

\section{METHOD 114 COMPARISON FOR STACK 296-A-22}

\subsection{Burpore and Beakaround}

This method provides the requirements for: (1) stack monitoring and semple collectlon methode approprlate for radionuclidas; (2) radiochemical mothods which ore used in determining the mounts of radionuclides collected by the stack sempling and; (3) qullity assurance mothods which are conducted in conjunction with these measurements. These methods ore appropriate for eniseions for stationary sources. A list of references is provided.

Many different types of facillties relesese radionuclides into alr. These radionuclides differ in the chemical and physical forms, half-lives and type of radiation emitted. The uppropriate combination of semple extraction, collection and analysis for an individual radionuclide is dependent upon many interreleted factors including the mixture of other radionuclides present. Because of this wide range of conditions, no single method for monitoring or sample collection and analysis of a radionuclide is applicable to all types of facillties. Therefore, "serles of methods based on "principles of measurement" are described for monitoring and sample collection and analysis which are applicable to the measurement of radionuclides found in effluent streams at stationary sources. This approach provides the user with the flexibllity to choose the most appropriate combination of monitoring and semple collection and analysis methods inich are applicable to the effluent strean to be measured.

\subsection{Stack Monltoring and Semole Collection Methode}

Monitoring and sample collection methode are described based on "principles of monitoring and acmple collection" which are applicable to the masurement of radionuclides from effluent strecm ot atotionery sources. Radionuclides of most elements will be in the particulate form in these offluent streams and can be readily collected using auitable filter media. Radionuclides of hydrogen, oxygen, carbon, nitrogen, the noble gases and in some circumstances lodine will be in the gaseous form. Radionuclides of thase elements will require ither the use of an in-line or off-line monitor to directly messure the radionuclides, or suitable sorbers, condensers or bubblers to collect the radionuclides.

2.1 Radionuclides as Particulates. The extracted effluent strean is passed through a filter madia to remove the particulates. The filter must have a high efficiency for removal of sub-micron particles. The guldance in ANSI N13.1.1969 shall be followed in using filter media to collect particulates (incorporated by reference-see $\$ 61.18$ ).

\section{Plant Documentation}

Gelman Sciences, Inter-Office Memorandum to Karol Butcher, October 30, 1991, RE: Versapor 3000, DOP efficiency.

WHC, 1992, Health Physics Procedure Manual, WHC-IP-0692

"Operation of Gaseous Effluent Sampling and Monitoring Systems," Health Physics Procedure No. 5.2.2.7, Rev 3

Drawing H-2-92505, Sheet 1 of 4 - Vessel Vent Stack Monitor System Installation

Drawing H-2-92505, Sheet 2 of 4 - Vessel Vent Stack Monitor Detalls

Drawing H-2-92505, Sheet 4 of 4 - Vessel Vent Stack Monitor Flow Diagram 
Response. A 47-mm Versapor* 3000 or equivalent air sample flltor is used for the record sampler. This filter is a membrane fliter good for collecting $0.3-\mu \mathrm{m}$ size particles with a collection offictency of $91 \%$.

2.2 Radionuclides as Gases.

Plant Documentation

WHC, 1992, Health Physics Procedure Manual, WHC-IP-0692

- "Sllver Zeollto Monttor/Change-Out Program At 241-AH Tank Farm And The 242-A Evaporator," 200 Area Health Physics Procedure No. 5.2.2.5, ReV 1

Drawing H-2-92505, Sheet 1 of 4 -Vessel Vent Stack Monitor System Instaliation

Drawing H-2-92505, Sheet 2 of 4 - Vessel Vent Stack Monitor Detalls

Drawing H-2-92505, Sheot 4 of 4 - Vessel Vent Stack Monitor Flow Diagram

Respense - Sllver zeolite cartridges are used and are designed to collect ${ }^{120} \mathrm{I},{ }^{311} \mathrm{I},{ }^{126} \mathrm{Sb},{ }^{113} \mathrm{Sn},{ }^{103} \mathrm{Ru}$, and ${ }^{108} \mathrm{Ru}$.

2.3 Definition of Terme

No response requitred.

3.0 Radionuclide Analysis Methods

The analys is methods have been evaluated by 222-S Laboratory cognizant personnel and are included as Appendix $G$.

\subsection{Quality Assurance Methods}

Each facillty required to measure thelr radionuclide emiseions shall conduct a quallty assurance progrem in conjunction with the radionucllde emission mesesurements. This progrem shell assure that the emission measurements are representative, and are of known precision and accuracy and uhall include administrative controls to assure prompt response when emission measurements indicate unexpectedly large emiseions. The progrem shall consist of eystem of polfcies, orgenizational responsibilities, written procedures, date quality specifications, audits, corrective actione and raports. This quality assurance progrem shall include the following progren elements:

*Trademark of Gelman Sciences, Inc. 
WHC-EP-0536-1

4.1 The orgentzational etructure functlonal responsibllitles, levels of authority and lines of commantcations for all ectivitles related to the emiselons measurement program shall be Identlfled and documented.

\section{The Organizational structure}

See Section 6.2 of the main part of this document for the organizational structure.

4.2 Adminlstrative controls whall be prescribed to ensure prompt reapones in the event that enleston lovels increase due to unplanned operations.

"WHC-CM-4-12, Part B, Section 1.14, REV 1, "Alarm Response and Management." Establishes requirements and provides gutdance for responding to alarms that are the responsibility of Hoalth Physics (HP)."

WHC-CM-4-12, Part A, Section 2.1, REV 0, "Radiological Problem Reporting Program." The radiological problem roporting program provides a documented record of observed radiological problems, a mechanism for reporting these problems to managoment for action, a capability to track and monitor the progress of the planned corrective actions, and a database for assessing tronds in radfological program performance and needed actfons.

WHC-CM-4-12, Part B, Section 12.1, REV 1, "Emergency Response." An emergency is a sudden, unexpected event requiring immediate response to mittgate impacts to people, property, or the environment. When radioactive material is involved, Hoalth Physics (HP) plays a major role in evaluating, controlling, and recovering from the event. To perform this function, HP personnel receive training to respond to a variety of emergency situations. The HP procedures are written to provide guidelines to respond to emergencles. Together, the training and the written procedure detall the HP Emergency Response Program.

Emergency Response. The HP personnel are, in many situations, the first to respond to a radiological emergency. The ability to assess and evaluate the situation and take immediate steps to minimize the effects of the event is crucial for controlling the emergency. The HP personnel must use their training and experience to make good decistons during the initial response to an emergency.

An emergency response may be initiated by personnel observing the event, alarms, the Patrol Operation Center or the Emergency Control Center(s) once they are manned. For a planned response, HP personnel shall be in teams of at least two. Out of necessity (e.g., backshift response), one member could be an Operations person, or other emergency service person such as fire or patrol. A rapid response is required; however, no undue risks should be taken nor should employee personnel safety be compromised. The type of emergency determines the level of planning for HP response. For example, a continuous air monitor (CAM) alarm or a small radioactive 
splli requires little planning for the initial response. However, when an emergency causes a facllity ovacuation, preplanning (e.g., stay time, entry route, etc.) and approval of the Buflding/Facility Emergency Director is necessary for a re-entry.

Although HP personnel respond to an emergency using basic guidelines, an area/facllity may have specific procedures that have prlority over these guidelines.

WHC-IP-0692, Section 12.1.2.3, REV 2, "Effluent Exhaust CAM Alarm Response." This procedure establishes the standard method of handling samples from, and response to alarms at, effluent oxhaust CAN* systems. This procedure describes the steps and matertal necessary to exchange, perform field concentration calculations, and submit suspect samples for "rush" or "red envelope" analysis when responding to alarms on effluent exhaust CAM systems.

WHC-IP-0692, Section 12.1.6, REV 2, "Stack Effluent Release Response." This procedure establishes guidelines for responding to a potential or actual release of radioactive materlal through exhaust stacks. The procedure describes the immediate actions to respond to an exhaust CAM stack alarm (1.0., CAM monitoring downstream or upstream of the final filtration).

WHC-IP-0692, Procedure No. 12.2.1, REV 2, "Emergency Response Air Sampling." This procedure establishes the instruction and guidelines for air sampling in an emergency situation. The procedure describes the steps for sampling air both inside and outside facilities when a release of radioactive material is suspected.

WHC-IP-0692, Section 12.2.3, REV 0, "Health Physics Emergency Response Team." This procedure provides the organizational structure, responsibilities, and steps for an initial emergency response for the HP Emergency Response Team (ERT) and the HP Technician (HPT) Field Survey Teams. The HP ERT and the HPT Field Survey Teanis may be requested to respond to an emergency when it is deemed that an environmental release of radioactive material may extend beyond the control of a facility or outside the boundaries of the Hanford Site. These teams will have monitoring responsibilities only outside the boundaries of the event site.

WHC-IP-0692, Section 12.2.4, REV 2, "Emergency Radioactive Plume Tracking." This procedure establishes the instructions to track a plume created from a radioactive material release to the environment. This procedure describes the steps to track and determine if a radioactive beta-gamma plume is at ground level or at an elevated level.

*The CAM serves as a warning device to alert personnel to releases that exceed normal operating parameters. A CAM collects particulates on a filter monitored continuously by a radiation detector. The CAM filter may be used as a backup for the record sample. 
Notifications and reporting of speciflc events related to environmental roleases and ovents involving effluents or hazardous materfals are reported via instruction given in WHC-CM-5-7, Tank Farms, Grout, and Solid Waste Management Administration Manual, Section 1.22, "Tank Farms Occurrence Reporting and Processing of Operations Information." This procedure establishes and implements speciflc criterla and requirements for the identification, categorization, notificaticn, and reporting of occurrences at the tank farms, as required by WHC-CM-1-3, MRP 5.14, "Occurrence Reporting and Processing of Operational Information."

4.3 The semple collection and analysls procedures used in mesuring the emise ions shall be described including there appl lcable:

4.3.1 Identiflcation of sampling sites and number of sampling points, including the rationale for site selections.

The vessel vent stack is $20.3 \mathrm{~cm}$ ( $8 \mathrm{in}$.) in diametor. The samplo probe location within the vessel vent stack is located on the fourth floor of the condenser room. The closest flow disturbances are described below.

- Downstream--the sample return line enters the stack approximately $61 \mathrm{~cm}(2 \mathrm{ft})$ below the probe location. This equates to three stack diameters.

- Upstream--the elbow in the vessel vent which takes the stack outside the bullding is approximately $1.4 \mathrm{~m}$ (56 in.) above the probe. This equates to seven stack diameters.

This meets the criteria established in 40 CFR 60, Appendix A, Method 1A.

There are two nozzles on this probe. This is as recommended in American National Standards Institute (ANSI) N13.1-1969, Appendix A, Section A3.2 (ANSI 1969), for this size stack (8 in.).

\subsubsection{A description of sempling probes and representativeness of the semples.}

The sample probe consists of two inlets that point down into the upflowing gas. Each inlet is approximately centered in each of the two equal annual areas. This is shown on drawing H-2-69316. It is easily shown (from Table Al, ANSI N13.1-1969, and from information on the stack flow rate) that the flow within the stack is highly turbulent resulting in a uniform velocity distribution across the cross-sectional area of the stack. As stated in ANSI N13.1-1969, Appendix A, Section A3.3.2, "as the flow becomes more turbulent, the velocity becomes more neariy uniform across the duct." Based on this it can be shown that the sampling probe is isokinetic. See discussion in Section 4.3.6." 
4.3.3 A description of any continuous monitoring syetems used to mesure collesions, including the seneltivity of the eystem, callibration procedures and frequency of callibration.

Not applicable; emissions are not monitored continuousiy for compltance demonstration. See discussion in section 4.3.6.

4.3.4 A description of the semple collection syatem for each redionucl lde masured, including frequency of collection, callibration procedures and frequency of callibration.

The radionuclides are collected through the probe discussed in Section 4.3.1 above. Gaseous radionuclides are collected with sliver zeolite cartridges that are designed to collect ${ }^{120} I,{ }^{131} I$, ${ }^{125} \mathrm{Sb},{ }^{113} \mathrm{Sn},{ }^{103} \mathrm{Ru}$, and ${ }^{108} \mathrm{Ru}$. The gross filter effictency of a silver zeolite is based on the particular absorbed/adsorbed radionuclide boing evaluated and the porosity of the filter. For uses at the Hanford Site (1.0., ruthentum, lodine), the efficiency is 99.2 to 99.98 (taken from Table 0-2 of Air Sampling Instruments, American Conforence of Governmental Industrial Hyglenists, seventh edition [ACGIH 1989]).

The sliver zeoltte cartridges are exchanged as follows:

- When the cartridges have been in the sample for 1 week

- When radiation readings indicate a bulldup of greater than $16 \mathrm{mrem} /$ hour within the last 8 hours

- When requested by operations management.

Particulate radionuclides are collected with a record sampler. The record sampler uses a 47-mm Versapor* 3000 or equivalent air sample fllter for the record sampler. This membrane filter collects $0.3 \mathrm{\mu m}$ size particles with a collection effictency of $91 \%$.

If at all possible, record air samples are left running for a full 168-hour (7-day) week to ensure a representative sample.

4.3.5 A description of the laboratory analys is procedures used for each radionuclide measured, including frequency of analysis callbration procedures and frequency of callibration.

See Appendix G.

4.3.6 A dascription of the sample flow rate measurement systems or procedures, including calibration procedures and frequency of calibration.

The sample collection and monitoring system consist of a record sampler, two silver zeolite cartridges, and two Continuous Air Monitors (CAMs). The record sample and silver zeolite portion of the sampling system is considered the regulatory portion of the system. The record sampler and sllver zeolite cartridges provide the basis for reporting the amount and concentration of 
radionuclides released to the environment. The generated reports are forwarded to all appropriate organizations and agenctes. The CAMs are considered operational safety devices and are set to alarm If emissions are detected above preset levels. The difference between the CAMs and the record sampler is the fact that there is a radiation detector above or near the collection filter within the CAM. The record sampler contains only a collection filter. If the fllter paper of the record sampler is not useable for some reason when it is exchanged for analysis, the filter paper from one of the CAMs could be used instead. For this reason the CAMs may be considered as regulatory backup devices. The detector portion (and the assoctated electronics) of the CAMs are not considered regulatory.

The sampling system is designed with a single sampling probe. The sample from the probe is split once and routed to the record sampler (the silver zeolite cartridges are installed just after the record sampler) and to another splitter. This second splitter splits the flow again to an alpha CAM and to a beta/gamma CAM.

This sampling system is designed to be isokinetic by sizing the stack's sampling probe to both, a speclfled sample flow rate and on measured average stack flow rates. For most of Tank Farms the record sampling portion of the sampling system is designed to a 2.2 CFM flow rate. Historically, the 2.2 CFM rate was selected to represent the respiration rate of the "average" worker. A lower flow rate of 2.0 CFM is allowed for the CAMs. However, the design was still for 2.2 CFM. The lower flow rate (2 CFM) theoretically results in the CAMs oversampiling the stream. Since CAMs are monitoring devices which provide for notification of increasing particulate radionuclide emisstons, this oversampling concept provides for a sort of early warning signal. Somehow, though, over the years the 2 CFM setting for the CAMs has been interpreted to apply to the record samplers as well. Now 2 CFM is the nominally expected setting. Since all three portions (the record sampler and the two CAMs) share the same sampling probe, the sample flow rate is readily calculated to be $2.8 \mathrm{~L} / \mathrm{sec}\left(6 \mathrm{ft}^{3}, \mathrm{~min}[\mathrm{cfm}]\right)$.

The entire sampling collection and monitoring system is considered to consists of the following elements:

- The sampling probe which withdraws the sample from the stack.

- The sample transport line which transports the sample to a sample collection and/or other detection devices.

- The collection and/or detection devices.

- The rotameter which measures the flow through the system.

- The gasmeter or totalizer which totals the sample flow.

- The pressure or vacuum gauge which measures the vacuum in the system. 
- The flow switch (also called the pressure switch) indicates when the sample flow falls below established limits.

- The flow regulator which adjusts to maintain an established flow rate within the system.

- The vacuum pump which supplies the flow through the system.

- The timer which indicates the length of time the collection devices have been collecting a sample.

Each of these elements are discussed in further detail below.

THE STACK'S SAMPLING PROBE AND SAMPLE TRANSPORT LIME: The sampling probe withdraws a sample from the stack section located on the fourth floor of the condenser room. The sampler probe incorporates the use of two nozzles for sampling the stack flow (reference drawing H-2-69316 [AEC 1974]). At an actual sample flow rate of 2.0 CFM (the record sampler and the two CAMs total 6.0 CFM) the nozzles are sized to be isokinetic at an actual stack flow rate of 750 CFM. A further analysis is given under the rotameter discussion below.

The sample transport line was selected and installed in a manner designed to minimize particle loss attributed to gravity settling, turbulent impaction, and electrostatic effects. The run lengths, bend radii, and tube transition severity of the sample transport line are minimized to the extent practical. This line extends from the sample probe down to the top of the instrument rack located on the third floor of the condenser room. The line is approximately 10.5 feet long and contains two $45^{\circ}$ bends designed with bend radi $i$ of not less than 10 inches. The line is sized to $I^{\prime \prime} O D$ by $0.065^{\prime \prime}$ WALL. The sample transport line is heat traced (operating at $43^{\circ} \mathrm{C}$ $\left.\left[110^{\circ} \mathrm{F}\right]\right)$ to inhibit condensation of moisture and resultant sample flow retardation by maintaining the temperature above the dew point.

THE RECORD SAMPLE COLLECTION FILTER PAPER AND HOLDER: The record sample collection filter paper collects particulate radionuclides from the stack or stream. The filter used is a Gelman Sciences Versapor 3000 - Supported Membrane type. The imanufacturer specifies that this filter has a $91 \%$ collection efficiency for 0.3 micron particles (reference Gelman Sciences, Inter-Office Memorandum to Karol Butcher, October 30, 1991, RE: Versapor 3000, DOP efficiency).

The make/model of the filter holder is BGI INC FI (reference drawing H-2-92489). The record sample holder is described as follows:

- Large outside diameter with knurled outer ring for ease of opening.

- Rubber "0" ring gaskets used to seal the sample holder. 
- Fine mesh screen behind the sample filter to keep the sample a constant distance from the inlet.

The holder is inspected for wear and leaks on a daily, weekly, and monthly basis per Health Physics Procedure 5.2.2.6, Rev 3, "Gaseous Effluent Sampling and Monitoring System Operability Inspection." The filter paper is exchanged on a weekly basis per Health Physic Procedure 5.2.2.7, Rev 3 "Operation of Gaseous Effluent Sampling and Monitoring Systems," Health Physics Procedure No. 5.2.2.7, Rev 3. The Health Physic Procedure are contained in WHC, 1992, Health Physics Procedure Manual, WHC-IP-0692.

THE SILYER ZEOLITE CARTRIDGE: Directly after the record sampler, the flow passes through two silver zeolite cartridge filters. These filters collect volatile radionuclides. Silver zeolite filters are designed to collect ${ }^{129} \mathrm{I},{ }^{131} \mathrm{I},{ }^{125} \mathrm{Sb},{ }^{113} \mathrm{Sn},{ }^{103} \mathrm{Ru}$, and ${ }^{106} \mathrm{Ru}$. The cartridge filters are exchanged weekly and sent to the laboratory for analysis per Health Physics procedure No. 5.2.2.5, Rev 1, "Silver Zeolite Monitor/Change-Out Program At 241-AW Tank Farm And The 242-A Evaporator."

THE ROTAMETER measures the flow rate through the sampling system. The rotameter consists of a ball floating in a column of fluid (air) in a tube. There is no calibration. This model has neither flow adjustment nor calibration scale adjustment. The manufacturer states: "...If used in the proper application, with an acceptable media, the flowmeter will give a lifetime of service without the need for calibration" (reference DWYER INSTRUMENTS, INC letter to WHC, addressed to Jeff Summerhays, dated September 28, 1992). The manufacturer mentions checking calibration only in the shop with a certified air flow device. The operating instructions state "DO NOT attempt to check the Dwyer Rate-Master Flowmeters with a similar flowmeter as seemingly unimportant variations in piping and back pressure may cause noticeable differences in the indicated reading..." (CVI file 20553, dated August 14, 1980).

The applicable drawing for thi's rotameter is $\mathrm{H}-2-92489$ and it specifies the following:

Make/Model :

DWYER/RMC-103PF

Scale: 10" SCALE, 20 .. 200 SCFH

Accuracy: $\pm 10 \%$ AT 2.2 SCFM

The facility instrument number is FI-VV-1. This instrument is scaled in units of 5 SCFH (0.08 SCFM) and is readable to \pm 2.5 SCFH (0.04 SCFM).

This instrument is designed to operate in pressures up to 35 psi and in temperatures up to $130^{\circ} \mathrm{F}$. However, the readout is designed to be accurate only at standard condition of pressure and temperature. Under any other conditions the rotameters give false readings unless compensated for using appropriate equations. The sampling systems are not at standard pressure, and because of this these instruments 
do not read true. A special square root function (equation) must be used if the true flow rate is desired. The 1iterature (United States Nuclear Regulatory Commission Office of Inspection and Enforcement, Washington D.C. 20555, dated December 16, 1982, IE Information Notice No. 82-49: CORRECTION FOR SAMPLE CONDITIONS FOR AIR AND GAS MONITORING) gives this equation as:

$$
\text { Qs/Q0 }=K s / K_{0} *\left[\left(P_{0} * T s\right) /(P s * T O)\right]^{k}
$$

where

Qs - Actual compensated sample flow rate.

Qo - Operating condition sample flow reading of the rotameter.

Po - Operating condition sample system vacuum value in inches $\mathrm{Hg}$.

Ps - Standard atmospheric pressure (29.92 inches $\mathrm{Hg}$ ).

To - Operating condition temperature ( $\left.{ }^{\circ} \mathrm{K}\right)$.

Ts - Standard temperature $\left(294^{\circ} \mathrm{K}\right)$.

Ks - The width of the rotameter chamber in which the ball floats divided by the width of the ball floating in the chamber.

Ko - A function of the operating conditions which may be determined experimentally.

The manufacturer states that the Ks/Ko value is one (per telecon). Apparently this instrument is designed so that these two variables cancel each other out.

A similar equation to that given above is used in emission calculations. However, temperature values are not used. The literature claims that only a $\mathbf{\pm 5}$ error results if temperature compensations are ignored between 24 and $116^{\circ} \mathrm{F}$. This is the case at Hanford since the emission calculations only compensate for the pressure readings. Typically the operating temperature of the sampling systems can be assumed to be at $110^{\circ} \mathrm{F}$. This is the temperature that the sample transfer line heat tracing is designed to operate at. Accordingly a more exact error* on the rotameter reading due to temperature can be computed to be approximately $\mathbf{+ 4 \%}$.

The 1 iterature claims that flow rate readings from a rotameter are accurate to $\pm 5 \%$ if temperature and pressure are taken into account. The rotameter readings are not compensated in the field. This means that the sample which is collected may not be as representative as it could be. The following example is given to evaluate this:

The equation above is used to calculate what the actual flow rate in the sampling system would be under a typically worse case scenario. In this scenario the system has been adjusted to give a rotameter indication of 2.0 CFM. The following assumptions are used:

- Typically worse vacuum in the system is not greater than 10 inches $\mathrm{Hg}$.

* Error is defined as positive if Qo is greater that Qs. 
- It was also mentioned that the heat trace is designed to operate at $110^{\circ} \mathrm{F}-316^{\circ} \mathrm{K}$.

QS $=2.0\{[(29.92-10) 294] /[(29.92)(316)]\}^{k}=1.57$ CFM with an uncertainty of \pm 0.14 CFM or the actual fiow rate is from 1.71 to 1.44 CFM.

The uncertainty is due to the $\pm 5 \%$ error of the rotameter and the $\pm 5 \%$ error of the vacuum gauge (see discussion on vacuum gauge below).

The latest stack flow measurement was accomplished on $6 / 3 / 93$ per Work Package *2E-93-00672. The flow was measured to be 661 CFM. At that time the vacuum in the sampling system was reading about 6" $\mathrm{Hg}$. Also at that time the rotameter was reading $130 \mathrm{SCFH}$ (2.17 CFM). Using the equation above gives an actual sample flow rate of 1.87 CFM. This 1.87 CFM sample flow rate computes to an isokinetic stack flow rate at 665 CFM (assuming that the CAMs rotameters were indicating the nominal 2 CFM and pressure gauges were indicating approximately the same as the record sample loop's pressure gauge). The actual sample flow rate result can be shown to result in undersampling by less than $1 \%$ for 12 micron sized particles (reference Table Cl in ANSI N13.1-1969).

Calibration and inspection of the rotameter has been accomplished, in the past, on a 6 month basis via Maintenance Engineering Services Calibration Procedure, "Air Rotameter," Calibration Procedure \#PSCP-7-001. Since the manufacturer, as well as the CVI file (discussed above), indicates that calibration of this instrument is not necessary, a new system functional test/calibration procedure has been developed which, when completed and released (after appropriate approval) will be used to check the entire sampling system at the same time. The number of this new procedure is 6-TF-077.

THE GASMETER OR TOTALIZER totals the flow through the sampling system. This Gasmeter use to be made by Rockwell but they sold this product line to Equimeter. This totalizer complies with ANSI-ASC B109.1 specifications which states that a meter must remain within $\pm 2.0 \%$ accuracy at $1,000,000$ cubic feet. This is basically the same system used on homes across the country. The manufacturer suppl led data shows that this meter is well within the required accuracy (the regulations specify the accuracy to be within $2 \%$ ). In fact the data supplied showed this meter to be as accurate to $-0.4 \%$ at the maximum designed full rate and to $+0.2 \%$ accurate at $20 \%$ of the maximum designed full flow rate for an average volume of 100,000 cubic feet (letter from Equimeter to WHC, addressed to Jeff Summerhays).

The manufacturer is confident that the totalizer can operate for 20 years or more if a clean gas is passed, and the unit is not over pressurized (exceed the maximum flow rate). Over-pressurization would hasten the aging process. The years of residential service referred to here assume approximately 100,000 cubic feet of flow per year ( 2 million cubic feet in 20 years). Assuming the Vessel Vent 
systems operates 24 hours a day at approximately 120 cubic feet per hour, it will pass 2,000,000 cubic feet of air in 694 days (approximately 1.9 years).

This gasmeter was also evaluated in WHC-SD-GN-ES-001, "200 Area Stack Gas Record Sample Flowmeter." This document states that the useful life of this unit appears to be from one to two years when it is not used in a wet and corrosive environment. When used in a wet and corrosive environment, the fallure rate is reported to be from 3 to 6 months.

If this meter goes out of tolerance, the main problem, according to the manufacturer, is wear on the moving parts. When this happens the meters should be replaced. A replacement kit is avallable for this purpose and can be installed if the meter is found out of calibration.

The applicable drawing for this instrument is H-2-92489 and it specifies the following:

Make/Model: $\quad$ ROCKWELL MR-9, temperature corrected

Accuracy: $\quad \pm 10 \%$ AT 2.2 SCFM

The facllity instrument number is FQI-VV-1.

The MR-9 model number relates to the maximum flow for which this gas meter is designed. The 9 can be interpreted as 9 cubic meters per hour. This converts to approximately 5.3 cubic feet per minute. The maximum designed pressure for this unit is 5 psi. This meter has a 6 digit readout in cubic meters. Additional accuracy is provided for by a circular scale with 10 increments. Each increment indicates 0.005 cubic meters ( 0.1766 cublc feet). The needle must circle the scale twice for the first digit on the digital readout to increment once (indicating one tenth of a cubic meter).

The readout of these instruments are designed to be accurate only at standard pressure conditions (temperature is compensated for in this unit). Any other conditions cause them to give false readings. The sampling systems are not at standard pressure, and because of this, these instrument do not read true. A spectal equation must be used if the true totalized flow is desired. This equation is used in emission calculations. The equation is as follows:

$$
\text { Qs/Q0 - Po/Ps }
$$

where

$$
\begin{aligned}
& \text { Qs - Actual compensated sample volume. } \\
& \text { Qo - Operating condition sample volume reading. } \\
& \text { Po - Average operating condition sample system vacuum (in } \mathrm{Hg} \text { ). } \\
& \text { Ps - Standard atmospheric pressure }(29.92 \text { in } \mathrm{Hg}) \text {. }
\end{aligned}
$$

The uncertainty of the values given by this gasmeter in the typically worse case scenario (with the sampiling system operated 
under a 10" $\mathrm{Hg}$ vacuum) can be shown to be normalized to \pm 0.06 (multiplied by value used - meters, feet, etc). The uncertainty is due to the potential $\pm 2 \%$ error of the gasmeter and the $\pm 5 \%$ error of the vacuum gauge (see discussion on vacuum gauge below).

Calibration and inspection of the gasmeter has been accomplished on a 6 month basis via Maintenance Engineering Services Calibration Procedure, "Rockwell Type Gas Meter," Calibration Procedure PSCP-4-007. A new system functional test/calibration procedure has been developed which, when completed and released (after appropriate approval) will be used to check the entire sampling system at the same time. The number of this new procedure is 6-TF-077.

THE PRESSURE OR VACUUM GAUGE measures the vacuum in the system. The air coming from the stacks is first run through the record sample filter paper, then the flow meter and totalizer, and finally the air pump which sucks the air through the system. The more residue collected by sample filter paper the lower the pressure throughout the system. The filter papers are, generally, left in place and replaced on a weekly basis. Over this week, the vacuum within the sampling system increases. This gauge measures this pressure drop and the reading which are recorded are used in emission calculations to acquire the true flow rate (from the rotameter recorded reading) and/or totalized flow (from the gasmeter recorded reading) which was experienced in the sample system during the sample collection period.

The manufacturer states that this gauge has an error of $\pm 2 \%$ of span at any point between $25 \%$ and $75 \%$ of span. In tr. rest of the scale, an error of $\pm 3 \%$ is permissible. These gauges cannot be calibrated so they are replaced if they are found to be reading outside the tolerance limits. Drawing H-2-92490 specifies the following:

Make/Model :

MARSH $\#$ J4805

Scape: $30 " \mathrm{Hg}$

Accuracy: $\pm 10 \%$ of full scale

The facility instrument number is PI-VV-3. This gauge is scaled in 1 inch increments and should have a readability of \pm 0.5 inch.

Calibration and inspection of the pressure gauge has been accomplished on a 6 month basis via Maintenance Engineering Services Calibration Procedure, "Pressure and Vacuum Gauges," Calibration Procedure PSCP-4-091. Since the vacuum gauge cannot be calibrated, a new system functional test/calibration procedure has been developed which, when completed and released (after appropriate approval) will be used to check the entire sampling system at the same time. The number of this new procedure is 6-TF-077. This procedure gives instructions to replace this gauge if its tested 


$$
\text { WHC-EP-0536-1 }
$$

accuracy is outside $\pm 5 \%$ of scale. This $5 \%$ error was chosen for the following reasons:

- The orror spectfied by the manufacturer is at least $\pm 3 \%$ and the $\pm 10 \%$ specified on the drawing seemed too 1 lberal; espectally since the pressure value obtained from this gauge is necessary to compute the true flow rate and the total volume collected.

- It is recognized that use in the field will cause the accuracy of various instruments to wonder beyond the manufacturer's spectfled limits which are valid when the instrument is brand new.

- The vacuum within the sampling system affects the gas meter measurements more than the rotameter and the t10\% (spectfied on the drawing - see discussion under gasmeter above) allowable error is desired for the gas meter. See the equations given in the discussion of both the gas meter and the rotameter above.

- An error analysis (with a vacuum gauge orror of $\pm 5 \%$ of scale) on the gasmeter done with the sampling system at $10^{\mathrm{N}} \mathrm{Hg}$ vacuum (typically the worse case) gives an overall error of $\pm 9 \%$. This error includes the $\pm 2 \%$ error of the gas meter. This $\pm 9 \%$ error is the uncertainty divided by the computed value (see discussion above under gasmeter).

\section{IHE FLOW SWITCH (OTHERWISE CALLED THE PRESSURE SWITCH) indicates} when the sample flow falls below established limits. The purpose is three fold:

a) To prevent damage to the sample collection filter paper. As the filter paper loads up with particulates, the vacuum increases and the flow drops. If the vacuum increases too much the fllter may break through, thus preventing further collection.

b) To prevent nonrepresentative sampling due to anisokinetic sampling. As the flow drops, isokinetic conditions necessary to acquire a representative sample are not kept.

c) To indicate vacuum pump problems (e.g. no flow or falled condition).

The applicable drawing for this instrument is $\mathrm{H}-2-92490$ and it specifies the following:

Make/Mode1: $\quad$ CHEM-TEC EQUIP CO MODEL 500-316-BP OR 500-B-BP

CALIBRATED: To deactivate at 1.0 to 1.5 SCFM Continulty check is requited.

The facility instrument number is FSL-VV-3. 
Calfbration and inspection of the flow switch has been accomplished on a 6 month basis via Maintenance Engineering Services Calibration Procedure, "Chem-Tec Adjustable Flow Switch Model 500," Callbration Procedure PSCP-6-029. A new system functional test/calibration procedure has been developed which, when completed and released (after approprlate approval) will be used to check the entire sampling system at the same time. The number of this new procedure is 6-TF-077.

THF FLOW REGULATOR adjusts to maintain an established flow within the system. No calibration is required. Drawing H-2-92490 spectfies the following:

Make/Model: $\quad$ EBERLINE 10552-CO2 RAP-1

The facility instrument number is PCV-VV-3.

YACUUM PUMP INLET EILTER provides filtered air to the pump. This fliter should be replaced perfodically.

The filters will be cleaned via a now system functional

test/cal Ibration procedure has been developed which, when completed and released (after appropriate approval) will be used to check the entire sampling system at the same time. The number of this new procedure is 6-TF-077.

IHE PUMP is a constant flow device. Independent vacuum pumps are provided for each loop of the system (the record sampler, the alpha CAM, and the beta/gamma CAM). The pumps are fitted with twin quick disconnects. In this way each pump can be used as a backup to the others should one of the other pumps fall. The pump do not need calibration. The applicable drawing for this pump is $\mathrm{H}-2-92490$ and it specifies the following:

Make/Mode1: GAST MODEL NO. 0822-V103-G271X

The Pump shall be ofl-less carbon vane rotary pump with inlet and outlet filter/mantfold assemblies. Powered by $1 / 2 \mathrm{HP}, 115 / 230 \mathrm{VAC}$, $60 \mathrm{~Hz}$, single phase motor.

IHE IIMER indicates the length of time the filter paper has been collecting a sample. This information is necessary for emisston calculations. The power to the sampling systems is supplied via either switched or unswitch power receptacles. Power is lost to the switched receptacle when the exhauster fan is turned off. The record sampling system, along with this timer is designed to be plugged into the switched receptacle. In this way, this timer will indicate the length of time the exhauster has been running as well. This is important because the sampling system should only be sampling when the exhauster is on. The applicable drawing for this instrument is $\mathrm{H}-2-92494$ and it specifies the following:

Make/Model: $\quad$ CRAMER 10083 
WHC-EP-0536-1

Reading: Meter elapsed time resettable 5 digits, reads in hours. First digit reads in tens of an hour.

Accuracy: Certffled accurate to $\pm 1 \%$.

Must be calibrated prior to operation.

The manufacturer says (per telecon) that there is no adjustment on this timer, therefore no calibration can be accomplished.

\section{THE CAMS:}

The CAM loops (bota/garma and alpha) within the 296-A-22 stack offluent monitoring system have flow rate indicating and regulating capabilities. A flow rate regulator is provided on each loop to maintain a constant flow rate through the collection filter assembly to compensate for fliter loading effects. The CAM systems have local readout count-rate meters and remote recording capability in the control room (on the MCS). Audible and visible alarms, including high airborne radiation, instrument malfunction, and low sample fiow indications, are provided locally and on the MCs in the 242-A control room. In addition, high stack radiation and high stack alpha radiation al arms are annunclated on the computer automated survelllance system (CASS). An exhaust alpha monttor fallure alarm is also tied to the CASS.

Calibration and inspection of these CAMs are accomplished on an annual basis using the following procedures:

- Maintenance Engineering Services Calibration Procedure, "Eberline Beta Alr Monitor, Models AMS-3, AMS-3A, And 700300," Calibration Procedure PSCP-3-002

- PNL-MA 563, Section 4.2.2, "Eberline Alpha 4, 5, 5A Air Monitors Calibration Procedure."

Also the CAMs are inspected for on a dally, weekly, and monthly basis per Health Physics Procedure 5.2.2.6, Rev 3, "Gaseous Effluent Sampling and Monitoring System Operability Inspection." The fllter paper is changed out on a weekly basis per Health Physic Procedure 5.2.2.7, Rev 3 "Operation of Gaseous Effluent Sampling and Monitoring Systems," Health Phystcs Procedure No. 5.2.2.7, Rev 3. The Health Physic Procedure are contained in WHC, 1992, Health Physics Procedure Manual, WHC-IP-0692.

4.3.7 A description of the effluent flow rete measurement procedures, including frequency of mesesurements, callibration procedures and frequency of calibretion.

"For the vessel vent, flow measurements are accomplished quarterly via Procedure 7-GN-56. There are two ports spaced 90 apart located 24 inches above the sampling probe location on the stack. These ports are 32 inches below the elbow whtch diverts the stack flow to outside the building. These distances place this location at 3 duct diameter downstream and 4 duct diameters upstream of any flow 
disturbances. Measurements are taken in each port at 16 equal annular traverse points (32 in all)."

4.4 The objectives of the quallty assurance progran shall be documented and shall atate the required precision, accurecy and completenese of the coniselon masurement date including a description of the procedures used to essesse these parcmeters. Accuracy ls the degres of agreament of a meseurement with a true or known value. Precleion lo a messure of the agreament anong Individual measuremente of the cume paremeters under elmillar conditions. Completeness is a maseure of the enount of date obteined compared to the enount expected under normal conditions.

\section{See Append $1 \times 6$.}

4.5 A quallty control program shall be establlahed to evaluste and track the quallty of the emisesions mensurement dete egainst preset erlterle. The progrem should include there applicable avetem of replicates, spiked semples, split semples, blanks and control charts. the number and frequency of such qualley control checks shall be identifled.

\section{See Appendix G.}

4.6 A semple tracking syatem shall be establlehed to provide for positive identifleation of anples and date through all pheses of the semple collection. analyeis and reporting syatem. semple handling and preservotion procedures shall be establlehed to mainteln the integrlty of samples during collection, storage and analyela.

\section{Refor to Section 6.2 .3 of the main part of this document.}

4.7 Perfodic Internal and external audits shall be performed to monitor compllance with the quallty assurance program. These audits shall be performed in accordance with written procedures and conducted by personnel who do not have responsfbillty for performing any of the operations being audited.

Refor to Section 7.0 of the main part of this document.

4.8 A corrective action progrem shall be establlahed including criterite for when corrective action is needed, what corrective action will be taken and who is responsible for taking the corrective action.

Refer to Section 8.0 of the main part of this document.

4.9 Perlodic reports to reapons ible management shall be prepared on the performence of the emissiona measurements program. These reports should include essessment of the quillty of the data, results of audite and description of corrective actions.

Refer to Section 9.0 of the main part of this document.

4.10 The quality assurance progran should be documented in auality assurance project plon which should address each of the above requi rements.

The quality assurance program addressing stack 296-A-22 will be documented in a future quality assurance project plan. 


\section{REFERENCES}

40 CFR 60, "Standards of Performance of New Stationary Sources," Title 40, Code of Federal Regulations, Part 60, as amended, U.S. Environmental Protection Agency, Washington, D.C.

40 CFR 61, "National Emission Standards for Hazardous Air Pollutants," Title 40, Code of Federal Regulations, Part 61, as amended, U.S. Environmental Protection Agency, Washington, D.C.

ACGIH, 1989, Air Sampling Instruments, American Conference of Governmental Industrial Hyglenists, 7 th Edition, Cincinnat1, Ohfo.

AEC, 1974, Vessel Vent System Arrangement, Drawing No. H-2-69361, Atomic Energy Commission, Richland Operations Office, Richland, Washington.

ANSI, 1969, Guide to Sampling Airborne Radioactive Materials in a Nuclear Facility, ANSI N13.1-1969, Amertcan National Standards Institute, New York, New York.

Health Physics Procedure 5.2.2.6.

Procedure 7-GN-56.

"Gaseous Effluent Sampling and Monitoring System Operability Inspection," Health Physics Procedure 5.2.2.6, REV 2, Westinghouse Hanford Company, Richland, Washington.

Maintenance Engineering Services Calibration Procedure, "Eberline Beta Air Monitor, Models AMS-3, AMS-3A, And 700300," Callbration Procedure PSCP-3-002, Westinghouse Hanford Company, Richland, Washington.

Maintenance Engineering Services Calibration Procedure, "Eberline Alpha-4, -5, and 5A," Callbration Procedure PSCP-3-003, Westinghouse Hanford Company, Richland, Washington.

Maintenance Engineering Services Callbration Procedure, "Rockwell Type Gas Meter," Calibration Procedure PSCP-4-007, Westinghouse Hanford Company, Richland, Washington.

Maintenance Engineering Services Calibration Procedure, "Pressure and Vacuum Gauges, "Calibration Procedure PSCP-4-091, Westinghouse Hanford Company, Richland, Washington.

Maintenance Engineering Services Calibration Procedure, "Chem-Tec Adjustable Flow Switch Model 500," Callbration Procedure PSCP-6-029, Westinghouse Hanford Company, Richiand, Washington.

Maintenance Engineering Services Callbration Procedure, "Air Rotometer," Calibration Procedure PSCP-7-001, Westinghouse Hanford Company, Richland, Washington. 
WHC-CM-1-3, Management Requirements and Procedures, as amended, Westinghouse Hanford Company, Richland, Washington.

WHC-CM-4-12, Health Physics Practices Manual, as amended, Westinghouse Hanford Company, Richiand, Washington.

WHC-CM-5-7, Tank Farms, Grout, and Solid Waste Management Administration Manual, Westinghouse Hanford Company, Richland, Washington.

WHC-IP-0692, Westinghouse Hanford Health Physics Procedures Manual-All Areas, Westinghouse Hanford Company, Richland, Washington. 
WHC-EP-0536-1

This page intentionally left blank. 
WHC-EP-0536-1

APPENDIX E

METHOD 114 COMPARISON FOR STACK 296-A-40

Q. M. Crunnel 
WHC-EP-0536-1

This page intentionally left blank. 


\section{APPENDIX E}

\section{METHOD 114 COMPARISON FOR STACK 296-A-40}

\subsection{Purpose and Background}

This method provides the requirements for: (1) stack monitoring and sample collection methods appropriate for radionuclides; (2) radiochemical methods which are used in determining the anounts of radionuclides collected by the stack sampling and; (3) quality assurance methods which are conducted in conjunction with these measurements. These methods are appropriate for emissions for stationary $80 u r c e s$. A list of references is provided.

Many different types of facilities release radionuclides into air. These radionuclides differ in the chemical and physical forms, half-lives and type of radiation emitted. The appropriate combination of sample extraction, collection and analysis for an individual radionuclide is dependent upon many interrelated factors including the mixture of other radionuclides present. Because of this wide range of conditions, no single method for monitoring or semple collection and analysis of a radionuclide is applicable to all types of facilities. Therefore, series of methods based on "principles of measurement" are described for monitoring and sample collection and analysis which are applicable to the measurement of radionuclides found in effluent streams at stationary sources. This approach provides the user with the flexibility to choose the most appropriate combination of monitoring and sample collection and analys is methods wich are applicable to the effluent strean to be measured.

\subsection{Stack Monitoring and Samole Collection Methods}

Monitoring and sample collection methods are described based on "principles of monitoring and semple collection" which are applicable to the measurement of radionuclides from effluent streans at stationary sources. Radionuclides of most elements will be in the particulate form in these effluent streams and can be readily collected using a suitable filter media. Radionuclides of hydrogen, oxygen, carbon, nitrogen, the noble gases and in some circumstances iodine will be in the gaseous form. Radionuclides of these elements will require either the use of an in-line or off-line monitor to directly measure the radionuclides, or suitable sorbers, condensers or bubblers to collect the radionuclides.

2.1 Radionuclides as Particulates. The extracted effluent stream is passed through a filter media to remove the particulates. The filter must have a high efficiency for removal of sub-micron particles. The guidance in ANSI N13.1-1969 shall be followed in using filter media to collect particulates (incorporated by reference-see $\$ 61.18$ ).

\section{Plant Documentation}

Gelman Sciences, Inter-0ffice Memorandum to Karol Butcher, October 30, 1991, RE: Versapor 3000, DOP efficiency.

WHC, 1992, Health Physics Procedure Manual, WHC-IP-0692

- "Operation of Gaseous Effluent Sampling and Monitoring Systems," Health Physics Procedure No. 5.2.2.7, Rev 3

Response. A 47-mm Versapor* 3000 or equivalent air sample filter is used for the record sampler. This filter is a membrane filter good for collecting $0.3-\mu \mathrm{m}$ size particles with a collection efficiency of $95.8 \%$.

*Trademark of Gelman Sciences, Inc. 


$$
\text { WHC-EP-0536-1 }
$$

2.2 Radionuclides as Gases.

\section{Plant Documentation:}

WHC, 1991, Health Physics Procedure Manual, WHC-IP-0692

- "Stlver Zeolite Monitor/Change-Out Program At 241-AP Tank Farm," 200 Area Health Physics Procedure No. 5.2.2.4, Rev 0

Response: Silver Zeolite Cartridges are used and are designed to co17ect ${ }^{129} \mathrm{I},{ }^{131} \mathrm{I},{ }^{126} \mathrm{Sb},{ }^{113} \mathrm{Sn},{ }^{103} \mathrm{Ru}$, and ${ }^{106} \mathrm{Ru}$.

\subsection{Definition of Terms}

No response required.

3.0 Radionuclide Analysis Methods

The analysis methods have been evaluated by 222-S Laboratory cognizant personnel and are included as Appendix $G$.

\subsection{Quality Assurance Methods}

Each facility required to measure their radionuclide emissions shall conduct a quality assurance program in conjunction with the radionuclide emission measurements. This program shall assure that the emission measurements are representative, and are of known precision and accuracy and shall include administrative controls to assure prompt response when emission measurements indicate unexpectedly large emissions. The program shall consist of system of policies, organizational responsibilities, written procedures, data quality specifications, audits, corrective actions and reports. This quality assurence program shall include the following program elements:

4.1 The organizational structure functional responsibilities, levels of outhority and lines of communications for all activities related to the emissions measurement program shall be identified and documented.

For the organizational structure, refer to Section 6.2 of the main part of this document.

4.2 Administrative controls shall be prescribed to ensure prompt response in the event that emission levels increase due to unplanned operations.

WHC-CM-4-12, Part B, Section 1.14, REV 1, "Alarm Response and Management." Estabilishes requirements and provides guidance for responding to alarms that are the responsibility of Health Physics (HP).

WHC-CM-4-12, Part A, Section 2.1, REV 0, "Radiological Problem Reporting Program." The purpose of the radiological problem report program is to provide a documented record of observed radiological problems, a mechanism for reporting these problems to management for action, a capability to track and monitor the progress of the planned corrective actions, and a database for assessing trends in radiological program performance and needed actions. 
WHC-CM-4-12, Part B, Section 12.1, REV 1, "Emergency Response." An emergency is a sudden unexpected event requiring immediate response to mitigate impacts to people, property, or the environment. When radioactive material is involved, Health Physics (HP) plays a major role in evaluating, controlling, and recovering from the event. To be able to perform this function, HP personnel receive training to respond to a variety of emergency situations. Procedures for HPs (WHC-CM-4-12 and WHC-IP-0692) are written to provide guidelines to respond to emergencies. Together, the training and the written procedures detail the HP emergency response program.

Emergency Response. The HP personnel are, in many situations, the first to respond to a radiological emergency. The ability to assess and evaluate the situation and take immediate steps to minimize the effects of the event is crucial for controlling the emergency. The HP personnel must use their training and experience to make good dectsions during the initial response to an emergency.

An emergency response may be initlated by (1) personnel observing the event, (2) alarms, (3) the Patrol operation Center, or (4) the Emergency Control Center(s) once they are manned. For a planned response, HP personnel shall be in teams of at least two. out of necessity (e.g., backshift response), one member could be an Operations person or other emergency service person, such as a firefighter or patrol officer. A rapid response is required; however, no undue risks should be taken nor should employee safety be compromised. The type of emergency determines the level of planning for HP response. For example, a continuous air monitor (CAM) alarm or a small radioactive spill requires littlo planning for the initial response. However, when an emergency causes a facility evacuation, preplanning (e.g., stay time, entry route, etc.) and approval of the Building or Facility Emergency Director is necessary to re-enter.

Although HP personnel respond to an emergency using basic guidelines, an area or factlity may have spectfic procedures that have priority over these guidelines.

WHC-IP-0692, Section 12.1.2.1, REV 0, "OHP Response to DoubleShell/Aging Waste Tank Pressurization Alarm." This procedure establishes the method of Operational Health Physics (OHP) response to tank pressurization alarms on double-shell or aging waste tanks. This procedure describes the steps and material necessary to respond to, and perform investigative surveys after, tank pressurization al arms.

WHC-IP-0692, Section 12.1.2.3, REV 2, "Effluent Exhaust CAM Alarm Response." This procedure establishes the standard method of handling samples from, and response to alarms at, effluent exhaust CAM systems. This procedure describes the steps and material necessary to exchange, perform field concentration calculations, and submit suspect samples for "rush" or "Red Envelope" analysis, when responding to alarms on effluent exhaust CAM systems. 
WHC-IP-0692, Section 12.1.6, REV 2, "Stack Effluent Release Response." This procedure establishes guidelines for responding to a potential or actual release of radioactive material through exhaust stacks. This procedure describes the immediate actions to respond to an exhaust (CAM) stack alarm (1.0., CAM monitoring downstream or upstream of the final flltration).

WHC-IP-0692, Procedure No. 12.2.1, REV 2, "Emergency Response Air Sampling." This procedure establishes the instruction and guidelines for air sampling in an emergency situation. This procedure describes the steps for air sampling both inside and outside factilties when a release of radjoactive material is suspected.

WHC-IP-0692, Section 12.2.3, REV 0, "Health Physics Emergency Response Team." This procedure provides the organizational structure of, the instructions for, and the responsibilities of the HP Emergency Response Team and the HP Technicians Field Survey Teams. This procedure describes the steps for an initial emergency response by the HP Emergency Response Team (ERT) and HP Techniclans Field Survey Teams. The HP ERT and the HP Techniclans Fleld Survey Teams may be requested to respond to an emergency when it is deemed that an environmental release of radioactive material may extend beyond the control of a facility or outside the boundaries of the Hanford site. These teams will have monitoring responsibilities only outside the boundarles of the event site.

WHC-IP-0692, Section 12.2.4, REV 2, "Emergency Radioactive plume Tracking." This procedure establishes the instructions to track a radioactive beta-gamma plume created from a radioactive material release to the environment and determine if it is at ground level or at an elevated level.

Notifications and reporting of specific events related to environmental releases and/or events involving effluents and/or hazardous materials are reported via instruction given in WHC-CM-5-7, Tank Farms, Grout, and Solid Waste Management Administration Manual, Section 1.22, "Tank Farms Occurrence Reporting and Processing of Operations Information." The purpose of this procedure is to establish and implement specific criteria and requirements for the identification, categorization, notification, and reporting of occurrences at the tank farms, as required by WHC-CM-1-3, MRP 5.14, "Occurrence Reporting and Processing of Operational Information."

4.3 A description of the sample collection and analysis procedures used in measuring the eniseion, including where applicable:

4.3.1 -. Identification of sampling sites and number of sampling points, including the rational for site selection.

The 241-A-40 stack measures $25.4 \mathrm{~cm}$ (10 in.) in diameter. The sample probe assembly is located $2.4 \mathrm{~m}(8 \mathrm{ft}$ ) above the fan discharge point into the stack and $50.8 \mathrm{~cm}$ ( 20 in.) below the top of the stack. The closest flow disturbances are approximately 


$$
\text { WHC-EP-0536-1 }
$$

9.6 stack diameters downstream (the fan discharge point) and two stack diameters upstream (the top of stack).

There are two nozzles on this probe. Thts is as recommended in ANSI N13.1-1969, Appendix A, Section A3.2 (ANSI 1969), for this size stack, $25.4 \mathrm{~cm}(10 \mathrm{ln}$.).

\subsection{2 - A deseription of the sempling probes and representativeness of the semples.}

The sample probe consists of two inlets that point down into the upflowing gas. Each inlet is approximately centered in each of the two equal annual areas. This is shown on drawing H-2-91245. It is easlly shown (from Table A1, ANSI N13.1-1969, and from information on the stack flow rate) that the flow within the stack is highly turbulent resulting in a uniform velocity distribution across the cross-sectional area of the stack. As stated in ANSI N13.1-1969, Appendix A, Section A3.3.2, "as the flow becomes more turbulent, the velocity becomes more nearly uniform across the duct." Based on this it can be shown that the sampling probe is isokinetic. See discussion in Section 4.3.6.

4.3.3 - A description of any continuous monitoring systems used to masure emiselons, includine the sensitivity of the system, callibration procedures and frequency of callbration.

Not applicable; emissions are not monitored continuousiy for compliance demonstration. See discussion in Section 4.3.6.

\footnotetext{
4.3.4 -. A descripetion of the sample collection syeteme for each radionuclide measured, including frequency of collection, callibration procedures and frequency of calibration.
}

The radionuclides are collected through the probe discussed in Section 4.3 .1 above. Gaseous radionuclides are collected with sliver zeolite cartridges that are designed to collect ${ }^{120} I,{ }^{131} I$, ${ }^{125} \mathrm{Sb},{ }^{113} \mathrm{Sn},{ }^{103} \mathrm{Ru}$, and ${ }^{108} \mathrm{Ru}$. The gross filter efficiency of a sllver zeolite is based on the particular absorbed/adsorbed radionuclide being evaluated and the porosity of the filter. For uses at the Hanford Site (1.e., ruthentum, lodine), the effictency is 99.2 to 99.98 (taken from Table 0-2 of Air Sampiing Instruments, American Conference of Governmental Industrial Hyglenists, seventh edition [ACGIH 1989]).

The sllver zeolite cartridges are exchanged as follows:

- When the cartridges have been in the sample for 1 week

- When radlation readings indicate a buildup of greater than $16 \mathrm{mrem} /$ hour within the last 8 hours

- When requested by operations management.

Particulate radionuclides are collected with a record sampler. The record sampler uses a 47-mm Versapor* 3000 or equivalent air sample 
WHC-EP-0536-1

filter for the record sampler. This membrane f1lter collects $0.3 \mu \mathrm{m}$ size particles with a collection efficiency of $91 \%$.

If at all possible, record air samples are left running for a full 168-hour (7-day) week to ensure a representative sample.

4.3.5 -. A deseription of the laboratory analyale procedures used for each redionucllde maneured, including frequency of inalyels, cellibration procedures and frequency of callibration.

See Append1X 6.

4.3.6 -. A deseription of the semple flow rate messurenent syetem or procectures, including callibretion procedures ard frequency of callibration.

The sample collection and monttoring system consist of a record sampler, two silver zeolite cartridges, and one Continuous Air Monttors (CAM). The record sample and sllver zeolite portion of the sampling system is considered the regulatory portion of the system. The record sampler and sliver 2001 te cartridges provide the bas is for reporting the amount and concentration of radionuclides released to the environment. The generated reports are forwarded to all appropriate organizations and agencies. The CAM is considered operational safety devices and is set to alarm if emisstons are detected above preset levels. The dlfference between the CAM and the record sampler is the fact that there is a radiation detector above or near the collection filter within the CAM. The record sampler contains only a collection fliter. If the flltor papor of the record sampler is not useable for some reason when it is exchanged for analysis, the filter paper from the CAN could be used instead. For this reason the CAM may be considered as a regulatory backup device. The detector portion (and the assoclated electrontcs) of the CAM is not considered regulatory.

The sampling system is designed with two Identlcal sampling probes mounted side by side in the same horizontal plane. One probe routes its sample to the record sampler (the sllver zeolite cartridges are installed just after the record sampler). The other probe routes the sample to a beta/gamma CAM.

This sampling system is designed to be isokinetic by sizing the stack's sampiing probe to both, a specifled sample flow rate and on measured average stack flow rates. For most of Tank Farms the record sampling portion of the sampling system is designed to a 2.2 CFM flow rate. Historlcally, the 2.2 CFM rate was selected to represent the respiration rate of the "average" worker. A lower flow rate of 2.0 CFM is allowed for the CAMs. However, the design was still for 2.2 CFM. The lower flow rate (2 CFM) theoretically results in the CAMs oversampling the stream. Since CAMs are monitoring devices which provide for notlfication of increasing particulate radionuclide emissions, this oversampling concept provides for a sort of early warning signal. Somehow, though, over the years the 2 CFM setting for the CAMs has been interpreted to apply to the record samplers as well. Now 2 CFM is the nominally 
expected setting. The entire sampling collection and monitoring system is considered to consists of the following elements:

- The sampling probe which withdraws the sample from the stack.

- The sample transport line which transports the sample to a sample collection and/or other detection devices.

- The collection and/or detection devices.

- The rotameter which measures the flow through the system.

- The gasmeter or totalizer which totals the sample flow.

- The pressure or vacuum gauge which measures the vacuum in the system.

- The flow switch (also called the pressure switch) indicates when the sample flow falls below established 1 imits.

- The flow regulator which adjusts to maintain an established flow rate within the system.

- The vacuum pump which supplies the flow through the system.

- The timer which indicates the length of time the collection devices have been collecting a sample.

Each of these elements are discussed in further detall below.

IHE STACK'S SAMPLING PROBE AND SAMPLE IRANSPORT LIME: The sampling probes withdraw samples from the stack section. The probes are located 8 feet above the fan discharge ducts of the fan and 20 inches below the top of the stack. The sampler probe incorporates the use of two nozzles for sampling the stack flow (reference drawing H-2-91245). At the designed flow rate of 2.2 CFM the nozzles are sized to be isokinetic at an actual stack flow rate of 980 CFM. A further analysis is given under the rotameter discusston below.

The sample transport line was selected and installed in a manner designed to minimize particle loss attributed to gravity settling, turbulent impaction, and electrostatic effects. The run lengths, bend radil, and tube transition severity of the sample transport ine are minimized to the extent practical. This i ine extends from the sample probe down to the top of the instrument cabinet for an approximate length of 13.5 feet. The line contains a single $90^{\circ}$ bend designed with bend radius of not less than 10 inches. The line

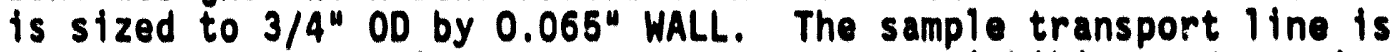
heat traced (operating at $43^{\circ} \mathrm{C}\left[110^{\circ} \mathrm{F}\right]$ ) to inhibit condensation of moisture and resultant sample flow retardation by maintaining the temperature above the dew point. 
IHE RECORD SAMPLE COLLECIION EILTER PAPER AND HOLLEE: The reCOPA sample collection fllter paper collects partfculate radtonucl ldes from the stack or stream. The fliter used is a Gelman Sctences Versapor 3000 - Supported Membrane type. The manufacturer spectfies that this flitur has a $91 \%$ collection effictency for $0.3 \mathrm{mlcron}$ particles (reference Gelman Sctences, Inter-Office Memorandum to Karol Butcher, October 30, 1991, RE: Versapor 3000, DOP efficioncy).

The make/model of the fllter holder is BGI INC FI (reference drawing H-2-92489). The record sample holder is described as follows:

- Large outside diameter with knurled outer ring for ease of opening.

- Rubber "0" ring gaskets used to seal the sample holder.

- Fine mesh screen behind the sample fllter to keep the sample a constant distance from the inlet.

The holder is inspected for wear and leaks on a dally, weekly, and monthly basis per Health Phys lcs Procedure 5.2.2.6, Rev 3, "Gaseous Effluent Sampling and Mont Soring System Operability Inspection." The filter paper is exchanged on a weokly bas is per Health Physic Procedure 5.2.2.7, Rev 3 "Operation of Gaseous Effluent Sampling and Monitoring Systems," Health Physics Procedure No. 5.2.2.7, Rev 3. The Health Physic Procedure are contained in WHC, 1992, Health Physics Procedure Manual, HHC-IP-0692.

IHE SILYER 2EOLITE CARTRIDGE: Directly after the record sampler, the flow passes through two silver 2eolite cartridge filters. These fliters collect volatile radionuclides. Silyer zeolite filters are designed to collect ${ }^{120} \mathrm{I},{ }^{131} \mathrm{I},{ }^{26} \mathrm{Sb},{ }^{13} \mathrm{Sn},{ }^{103} \mathrm{Ru}$, and ${ }^{100} \mathrm{Ru}$. The cartridge filters are exchanged weekly and sent to the laboratory for analysis per Health Physics procedure No. 5.2.2.4, Rev 0, "Silver Zeolite Monitor/Change-Out Program At 241-AP Tank Farm."

IHE ROTAMETEB measures the flow rate through the sampling system. The rotameter consists of a ball floating in a column of fluid (air) in tube. There is no callbration. This model has neither flow adjustment nor calibration scale adjustment. The manufacturer states: "...If used in the proper application, with an acceptable media, the flowmeter will give a lifetime of service without the need for calibration" (reference DWYER INSTRUMENTS, INC letter to WHC, addressed to Jeff Summerhays, dated September 28, 1992). The manufacturer mentions checking calibration only in the shop with a certiffed air flow device. The operating instructions state "DO NOT attempt to chenk the Dwyer Rate-Master Flowmeters with a similar flowmeter as seemingly unimportant varlations in piping and back pressure may cause noticeable differences in the indicated reading..." (CVI file 20553, dated August 14, 1980). 
The applicable drawing for this rotameter is $\mathrm{H}-2-92489$ and it spectfies the following:

Make/Model :

Scale:

Accurscy:
DWYER/RMC-103PF

10" SCALE, 20 - 200 SCFH

$\pm 10 \%$ AT 2.2 SCFM

This instrument is scaled in units of 5 SCFH (0.08 SCFM) and is readable to \pm 2.5 SCFH $(0.04$ SCFM). This instrument is destgned to operate in pressures up to 35 pst and in temperatures up to $1300^{\circ} \mathrm{F}$. However, the readout is designed to be accurate only at stindard conditton of pressure and temperature. Under any other conditions the rotameters give false readings unless compensated for using approprtate equations. The sampling systems are not at standard pressure, and because of this these instruments do not read true. A spectal square root function (equation) must be used if the true flow rate is desired. The ilterature (United States Nuclear Regulatory Commisston Offlce of Inspection and Enforcement, Washington D.C. 20555, dated Decembor 16, 1982, IE Information Notice No. 82-49: CORRECTION FOR SAMPLE CONOITIONS FOR AIR AND EAS MONITORING) gives this equation as:

$$
\text { Qs/Q0 - Ks/Ko*[(PO*Ts } \left.) /\left(P s * T_{0}\right)\right]^{k}
$$

where
Qs - Actual compensated sample flow rate.
Q0 - Operating condition sample flow reading of the rotameter.
Po - Operating condition sample system vacuum value in inches $\mathrm{Hg}$.
Ps - Standard atmospheric pressure $(29.92$ inches $\mathrm{Hg})$.
To - Operating condition temperature ("K).
Ts - Standard temperature $\left(294^{\circ} \mathrm{K}\right)$.
Ks - The width of the rotameter chamber in which the ball floats divided by the width of the ball floating in the chamber.
Ko - A function of the operating conditions which may be determined experimentally.

The manufacturer states that the $\mathrm{Ks} / \mathrm{Ko}_{0}$ value is one (per telecon). Apparently this instrument is designed so that these two variables cancel each other out.

A similar equation to that given above is used in emission calculations. However, temperature values are not used. The literature claims that only a $\pm 5 \%$ error results if temperature compensations are ignored between 24 and $116^{\circ} \mathrm{F}$. This is the case at Hanford since the emission calculations only compensate for the pressure readings. Typlcally the operating temperature of the sampling systems can bo assumed to be at 110 'F. This is the temperature that the sample transfer line heat tracing is designed to operate at. Accordingly a more exact error* on the rotameter reading due to temperature can be computed to be approximately $+4 \%$.

* Error is defined as positive if Qo is greater that Qs. 
The 11terature claims that flow rate raadings from a rotameter are accurate to $\pm 5 \%$ if temperature and pressure ara taken into account. The rotameter readings are not compensated in the field. Th1s means that the sample which is collected may not be as representative as it could be. The following example is given to evaluate this:

The equation above is used to calculate what the actual flow rate in the sampling system would be under a typlcally worse case scenarto. In this scenario the system has been adjusted to give a rotaneter indication of 2.0 CFM. The following assumptions are used:

- Typtcally worse vacuum in the system is not greater than 10 inches $\mathrm{Hg}$.

- It was also mentloned that the heat trace is designed to operate at $110^{\circ} \mathrm{F}=316^{\circ} \mathrm{K}$.

Qs $=2.0\{[(29.92-10) 294] /[(29.92)(316)]\}^{k}-1.57$ CFW with an uncertainty of $\pm 0.14 \mathrm{CFM}$ or the actual flow rate is from 1.71 to 1.44 CFM.

The uncertainty is due to the $\pm 5 \%$ error of the rotameter and the $\pm 5 \%$ error of the vacuum gauge (see discussion on vacuum gauge below).

This noxt example is given to evaluate the effictency of this system from recent real data:

The latest stack flow measurement was accomplished on $02 / 08 / 93$ per work package 2E-92-01446. The flow was measured to be 867 CFH. The vacuum in this system during the 1992 time frame averaged 4" $\mathrm{Hg}$. Assuming the sample flow is set to the nominal 2 CFM flow rate and using the equation above gives an actual sample flow rate of $1.80 \mathrm{CFM}$. This $1.80 \mathrm{CFM}$ sample flow rate computes to an isokinetic stack flow rate at $800 \mathrm{CFM}$. This actual sample flow rate result can be shown to result in oversampling by less than 14 for 12 micron sized particles (reference Table CI in ANSI N13.1-1969).

Calibration and inspection of the rotameter has been accomplished, In the past, on a 6 month basis via Maintenance Engineering Services Calfbration Procedura, "Air Rotameter," Calfbration Procedure - PSCP-7-001. Since the manufacturer, as well as the CVI file (discussed above), Indicates that calibration of this instrument is not necessary, a new system functional test/calibration procedure has been developed which, when completed and released (after appropriate approval) will be used to check the entire sampling system at the same time. The number of this new procedure is 6-TF-077.

IHE GASMETER OR TOTALIZER totals the flow through the sampling system. This Gasmeter use to be made by Rockwell but they sold this product line to Equimeter. This totalizer complies with ANSI-ASC B109.1 specifications which states that a meter must remain within $\pm 2.0 \%$ accuracy at $1,000,000$ cubic foet. This is basically the same 
system used on homes across the country. The manufacturer supplied date shows that this moter is well within the required accuracy (the regulations spectey the accuracy to be within 2X). In fact the date supplied showed this moter to be as accurate to $-0.4 \%$ at the maximum destgned full rate and to $+0.2 x$ accurate at $20 \%$ of the maximum designed full flow rate for an average volume of 100,000 cublc feet (lotter from Equimeter to WHC, addrassed to Joff Sunmerhays).

The manufacturer is confident that the totalizer can operate for 20 years or more if a clean gas is passed, and the unit is not over pressurized (exceed the maximum flow rate). Over-pressurization would hasten the aging process. The years of residential service reforred to here assume approximately 100,000 cubtc feet of flow par year (2 milliton cublc feet in 20 years). Assuming the Vessel Vent systems operates 24 hours a day at approximately 120 cublc foet per hour, it will pass 2,000,000 cuble poet of air in 694 days (approximately 1.9 years).

This gasmeter was also evaluated in WHC-SD-GN-ES-001, "200 Area Stack Gas Record sample Flowmeter." This document states that the useful ilfe of this unit appears to be from one to two years when it is not used in a wet and corrosive environment. When used in a wat and corrosive environment, the fallure rate is reported to be from 3 to 6 months.

If this meter goes out of tolerance, the main problem, according to the manufacturer, is wear on the moving parts. When this happens the meters should be replaced. A replacement $k$ tt is avallable for this purpose and can be installed if the meter is found out of calibration.

The applicable drawing for this instrument is $\mathrm{H}-2-92489$ and it spectfies the following:

Make/Model: $\quad$ ROCKWELL MR-9, temperature corrected Accuracy: $\pm 10 \%$ AT 2.2 SCFM

The MR-9 model number relates to the maximum flow for which this gas meter is designed. The 9 can be interpreted as 9 cubic meters per hour. This converts to approximately 5.3 cublc feet per minute. The maximum designed pressure for this unit is 5 pst. This moter has 6 digit readout in cublc meters. Additional accuracy is provided for by a ctrcular scale with 10 increments. Each increment indicates 0.005 cublc meters ( 0.1766 cubic feet). The needle must circle the scale twice for the first digit on the digital readout to increment once (indicating one tenth of a cubic meter).

The readout of these instruments are designed to be accurate only at standard pressure conditions (temperature is compensated for in this unit). Any other conditions cause them to give false readings. The sampling systems are not at standard pressure, and because of this, these instrument do not read true. A special equation must be used 
WHC- $[P-0536-1$

If the true totalized flow is desired. This equation is used in emission calculations. The equation is as follows:

$$
\text { Qs/Q0 }- \text { PO/Ps }
$$

where

Qs - Actual compensated sample volume.

Qo - Operating condition sample volume reading.

Po - Average operating condition sample system vacuum (in $\mathrm{Hg}$ ).

Ps - Standard atmospheric pressure (29.92 in Hg).

The uncertainty of the values given by this gasmeter in the typically worse case sconario (with the sampling system oporated under a $10^{\circ} \mathrm{Hg}$ vacuum) can be shown to be normalized to \pm 0.06 (multiplted by value used - motors, foot, otc). The uncertainty is due to the potential $\pm 2 X$ orror of the gasmoter and the $\pm 5 X$ error of the vacuum gauge (see discussion on vacuum gauge below).

Calibration and inspection of the gasmoter has been accomplished on - 6 month basis via Maintenance Engineering Services Calibration Procedure, "Rockwell Type Gas Meter," Callbration Procedure PSCP-4-007. A new system functional test/callbration procedure has been developed which, when completed and released (after approprlate approval) Will be used to check the entire sampling system at the same time. The number of this new procedure is 6-TF-077.

IHE PRESSURE OR VACUUM GAUGE moasures the vacuum in the system. The air coming from the stacks is first run through the record sample fliter paper, then the flow meter and totalizer, and finaliy the alr pump which sucks the air through the system. The more residue collected by sample fllter paper the lower the pressure throughout the system. The fllter papers are, generally, left in place and replaced on weekly basis. Over this week, the vacuum within the sampling system increases. This gauge measures this pressure drop and the reading which are recorded are used in emisston calculat ons to acquite the true flow rate (from the rotameter recorded reading) and/or totalized flow (from the gasmeter recorded roading) which was experienced in the sample system during the sample collection perlod.

The manufacturer states that this gauge has an error of $\pm 2 \%$ of span at any point between $25 \%$ and $75 \%$ of span. In the rest of the scale, an error of $\pm 3 \%$ is permissible. These gauges cannot be callbrated so they are replaced if they are found to be reading outside the tolerance limits. Drawing H-2-92490 spectfles the following:

Make/Mode1:

Scapo:

MARSH WJ805

Accuracy:

$$
\begin{aligned}
& 30 " \mathrm{Hg} \\
& \pm 10 \% \text { of full scale }
\end{aligned}
$$

This gauge is scaled in 1 inch increments and should have a readability of \pm 0.5 inch. 
Callbration and inspection of the pressure gauge has been accomplished on 6 month basis via Malntenance Englneering Services Callbration Procedure, "Pressure and Vacuum Gauges," Callbration Procedure PSCP-4-091. Since the vacuum gauge cannot be callbrated, a now system functional test/calibration procedure has been developed which, when completed and released (after appropriate approval) wtll be used to check the entire sampling system at the same time. The number of this now procedure is 6-fF-077. This procedure gives instructions to replace this gauge if its tested accuracy is outside $\pm 5 \%$ of scale. This $5 \%$ error was chosen for the following rasons:

- The error spectfled by the manufacturer is at least $\pm 3 \%$ and the $\pm 10 \%$ spectfied on the drawing seemed too Itberal; espectally since the pressure value obtained from this gauge is nocessary to compute the true flow rate and the total volume collected.

- It is recognized that use in the field will cause the accuracy of varlous instruments to wonder beyond the manufacturer's specifled limits which are valid when the instrument is brand new.

- The vacuum within the sampling system affects the gas moter measurements more than the rotameter and the $\pm 10 \%$ (specifled on the drawing - see discussion under gasmoter above) allowable orror is desired for the gas meter. See the equations given in the discussion of both the gas meter and the rotameter above.

- An error analysis (with a vacuum gauge error of $\$ 5 \%$ of scale) on the gasmeter done with the sampling system at $10^{\mathrm{N}} \mathrm{Hg}$ vacuum (typically the worse case) gives an overall error of $\pm 9 \%$. Thts error Includes the $\pm 2 \%$ error of the gas meter. Thts $\pm 9 x$ error is the uncertainty divided by the computed value (see discussion above under gasmeter).

IHE FLOW SWITCH (OTHERWISE CALLED THE PRESSURE SHITCH) indicates when the sample flow falls below established limits. The purpose is three fold:

a) To prevent damage to the sample collection filter paper. As the fllter paper loads up with particulates, the vacuum increases and the flow drops. If the vacuum increases too much the fllter may break through, thus preventing further collection.

b) To prevent nonrepresentative sampling due to anisokinetic sampling. As the flow drops, isokinetic conditions necessary to acquire a representative sample are not kept.

c) To indicate vacuum pump problems (e.g. no flow or falled condition). 
WHC-EP-0536-1.

The applicable drawing for this instrument is $\mathrm{H}-2-92490$ and it specifies the following:

Make/Model :

CHEM-TEC EQUIP CO MODEL 500-316-BP OR 500-B-BP

CALIBRATED:

To deactivate at 1.0 to $1.5 \mathrm{SCFM}$

Continuity check is required.

Calibration and inspection of the flow switch has been accomplished on a 6 month basis via Maintenance Engineering Services Calibration Procedure, "Chem-Tec Adjustable Flow Switch Model 500," Calibration Procedure PSCP-6-029. A new system functional test/calibration procedure has been developed which, when completed and released (after appropriate approval) will be used to check the entire sampling system at the same time. The number of this new procedure is 6-TF-077.

THE FLOW REGULATOR adjusts to maintain an established flow within the system. No calibration is required. Drawing H-2-92490 specifies the following:

Make/Model :

EBERLINE 10552-C02 RAP-1

VACUUM PUMP INLET FILTER provides filtered air to the pump. This filter should be replaced periodically.

The filters will be cleaned via a new system functional test/calibration procedure has been developed which, when completed and released (after appropriate approval) will be used to check the entire sampling system at the same time. The number of this new procedure is 6-TF-077.

THE PUMP is a constant flow device. Independent vacuum pumps are provided for each loop of the system (the record sampler, the alpha CAM, and the beta/gamma (AM). The pumps are fitted with twin quick disconnects. In this way each pump can be used as a backup to the others should one of the other pumps fail. The pump do not need calibration. The applicable drawing for this pump is $\mathrm{H}-2-92490$ and it specifies the following:

Make/Model: $\quad$ GAST MODEL NO. 0822-V103-G271X

The Pump shall be oil-less carbon vane rotary pump with inlet and outlet filter/manifold assemblies. Powered by $1 / 2 \mathrm{HP}, 115 / 230 \mathrm{VAC}, 60 \mathrm{~Hz}$, single phase motor.

THE TIMER indicates the length of time the filter paper has been collecting a sample. This information is necessary for emission calculations. The power to the sampling systems is supplied via either switched or unswitch power receptacles. Power is lost to the switched receptacle when the exhauster fan is turned off. The record sampling system, along with this timer is designed to be plugged into the switched receptacle. In this way, this timer wili indicate the length of time the exhauster has been running as well. 
This is important because the sampling system should only be sampling when the exhauster is on. The applicable drawing for this instrument is H-2-92494 and it specifies the following:

Make/Model: CRAMER 10083

Reading: Meter elapsed time resettable 5 digits, reads in hours. First digit reads in tens of an hour.

Accuracy: $\quad$ Certified accurate to $\pm 1 \%$.

Must be calibrated prior to operation.

The manufacturer says (per telecon) that there is no adjustment on this timer, therefore no calibration can be accomplished.

THE CAMS:

The CAM (beta/gamma) within the 296-A-40 stack effluent monitoring system has flow rate indicating and regulating capabilities. A fiow rate regulator is provided to maintain a constant flow rate through the collection filter assembly to compensate for filter loading effects. The CAM systems have local readout count-rate meters. Audible and visible alarms, including high airborne radiation, instrument malfunction, and low sample fiow indications, are provided. In addition, high stack radiation and high stack alpha radiation alarms are annunciated on the computer automated surveillance system (CASS). An exhaust alpha monitor failure alarm is also tied to the CASS.

Calibration and inspection of these CAMs are accomplished on an annual basis using the following procedures:

- Maintenance Engineering Services Calibration Procedure, "Eberl ine Beta Air Monitor, Models AMS-3, AMS-3A, And 700300," Calibration Procedure PSCP-3-002

- PNL-MA 563, Section 4.2.2, "Eberline Alpha 4, 5, 5A Air Monitors Calibration Procedure"

Also the CAMs are inspected for on a daily, weekly, and monthly basis per Health Physics Procedure 5.2.2.6, Rev 3, "Gaseous Effluent Sampling and Monitoring System Operability Inspection." The filter paper is changed out on a weekly basis per Health Physic Procedure 5.2.2.7, Rev 3 "Operation of Gaseous Effluent Sampling and Monitoring Systems," Health Physics Procedure No. 5.2.2.7, Rev 3. The Health Physic Procedure are contained in WHC, 1992, Health Physics Procedure Manual, WHC-IP-0692.

4.3.7 A description of effluent flow rate measurement procedures, including frequency of messurements, calibration procedures and frequency of calibration.

Flow measurements are taken quarterly via Procedure 7-GN-56. These measurements are taken from a single port located 20 inches above a 


\section{one foot deep stack flow straightener. The flow straightener section begins 14 inches above the fan discharge ducts of the fans. Measurements are taken in each port at 16 equal annular traverse points.}

4.4 The objectives of the quality assurance program shall be documented and shall state the required precision, accuracy, and completeness of the emission measurement data including description of the procedures used to assess these parameters.

\section{See Appendix G.}

4.5 The quality control program shall evaluate and track the quality of the emission measurement data against preset criteria. The progran should include, where applicable, system of replicates; spiked samples; split samples; blanks; and control charts. The number and frequency of such quality control checks shall be identified.

See Appendix G.

4.6 A sample tracking system shall be established to provide for positive identification of samples and date through all phases of the sampling collection, anslysis, and reporting system. Semple handling and preservation procedures shall be established to maintein integrity of the semples during collection, storage, and analysis.

\section{Refer to Section 6.2 .3 of the main part of this document.}

4.7 Periodic internal and external audits shall be performed to monitor compliance with the quality assurance program. These audits shall be performed in accordance with written procedures and conducted by personnel who do not have responsibility for performing any of the operations being audited.

\section{Refer to Section 7.0 of the main part of this document.}

4.8 A corrective action program shall be established including criteria for when corrective actions will be taken and who is responsible for taking the corrective action.

Refer to Section 8.0 of the main part of this document.

4.9 Periodic reports to responsible management shall be prepared on the performance of the emission measurements program. These reports should include assessment of the quality of the data, results of audits, and description of corrective actions.

\section{Refer to Section 9.0 of the main part of this document.}




\section{REFERENCES}

Procedure 7-GN-56

40 CFR 61, "National Emission Standards for Hazardous Air Pollutants," Title 40, Code of Federal Regulations, Part 61, as amended, U.S. Environmental Protection Agency, Washington, D.C.

ACGIH, 1989, Air Sampling Instruments, American Conference of Governmental Industrial Hygienists, Cincinnati, Ohio.

ANSI, 1969, Guide to Sampling Airborne Radioactive Materials in a Nuclear Facility, ANSI N13.1-1969, American National Standards Institute, New York, New York.

"Gaseous Effluent Sampling and Monitoring System Operability Inspection," Heal th Physics Procedure 5.2.2.6, REV 2, Westinghouse Hanford Company, Richland, Washington.

Maintenance Engineering Services Calibration Procedure, "Eberline Beta Air Monitor, Models AMS-3, AMS-3A, And 700300," Calibration Procedure PSCP-3-002, Westinghouse Hanford Company, Richland, Washington.

Maintenance Engineering Services Calibration Procedure, "Eberline Alpha-4, -5, and 5A," Calibration Procedure PSCP-3-003, Westinghouse Hanford Company, Richland, Washington.

Maintenance Engineering Services Calibration Procedure, "Rockwell Type Gas Meter, " Calibration Procedure PSCP-4-007, Westinghouse Hanford Company, Richland, Washington.

Maintenance Engineering Services Calibration Procedure, "Pressure and Vacuum Gauges, "Calibration Procedure PSCP-4-091, Westinghouse Hanford Company, Richland, Washington.

Maintenance Engineering Services Calibration Procedure, "Chem-Tec Adjustable Flow Switch Model 500," Calibration Procedure PSCP-6-029, Westinghouse Hanford Company, Richiand, Washington.

Maintenance Engineering Services Calibration Procedure, "Air Rotometer," Calibration Procedure PSCP-7-001, Westinghouse Hanford Company, Richland, Washington.

RL and RHO, 1984, Quality Assurance Level I, KI Primary Tank 10 Exhaust Stack Probe Assembly, Drawing No. H-2-91245, U.S. Department of Energy-Richland Operations Office and Rockwell Hanford Operations, Richland, Washington.

WHC-CM-1-3, Management Requirements and Procedures, as amended, Westinghouse Hanford Company, Richland, Washington.

WHC-CM-4-12, Health Physics Practices Manual, as amended, Westinghouse Hanford Company, Richland, Washington. 


\section{WHC-EP-0536-1}

WHC-CM-5-7, Tank Farms, Grout, and Solid Waste Management Administration Manual, as amended, Westinghouse Hanford Company, Richland, Washington.

WHC-IP-0692, Westinghouse Hanford Health Physics Procedures Manual-All Areas, Westinghouse Hanford Company, Richland, Washington. 
WHC-EP-0536-1

\section{APPENDIX F}

METHOD 114 COMPARISON FOR STACK 340-NT-EX

L. D. Schwartz

F-1 


\section{WHC-EP-0536-1}

Th1s page intentionally left blank. 


\section{APPENDIX F \\ METHOD 114 COMPARISON FOR STACK 340-NT-EX}

METHOO 116-TEST METHOOS PON MEAEURINO

RADIONUCLIDE EMISSIONS PROM STATIONARY SOURCES

\subsection{Burogene ind Bnakeroung}

This method provides the requiremente for: (1) stack monltoring and sumple collection mathods appropriate for redionuclides; (2) rediochemical mothods which ore used in determining the cmounts of redionuclides collected by the etack sempling and; (3) auallity sesurance mothods which ere conducted in conjunction with these imasurements. These mothode are approprlote for enfestons for statlonary sources. A list of references is provided.

Many different types of focillities rolease radlonuclides into olr. These redionuclides differ in the chemical and phyalcal forma, half-lives and type of radiation emitted. The approprlate combination of semple extraction, collection and analvele for an individual redionucllde is dependent upon many Interreleted factors Including the mixture of other radionuclides present. Because of this wide range of conditions, no ingle method for monltoring or semple collection and analyals of a redionuclide is appll leable to all types of tacillties. Therefore, "serles of methode based on "principles of mensurement" ore deseribed for monitoring and ample collection and analys le which ere applicable to the masurement of redionuclidese found in effluent strean at stationary sources. Ihls approach provides the waer with the flexibllify to choose the most approprlate combination of monltoring and semple collection and andyols methods mich are applicable to the effluent strean to be mesured.

\subsection{Strak Monltoring and semole collectlon mathods}

Monitoring and sumple collection mathods are described based on "princlples of monltoring and eample collection" which are applicable to the measurement of radionuclides from effluent otrecm ot etatlonary sources. Radionuclides of most elemente will be in the partlculate form in these effluent atreams and can be readily collected using aultable flltar madla. Radionuclides of hydrogen, oxyen, carbon, nitrogen, the noble gases and in som clrcumstances lodine wlll

be in the easeous form. Radionuclides of these elemente will requite elther the use of en in-line or off-line monitor to directly meseure the radionuclides, or sultable sorbers, condensers or bubblers to co! lect the redionuclides.

2.1 Radionuclides as Particulates. The extracted offluent strean is passed through o fllter medio to remove the particulates. The fllter must have a high efflciency for removal of ub-micron perticles. The guidance in AMSI N13.1-1969 hall be followed in ueing filter madie to collect particulates (incorporated by reference-see $\$ 61.18$ ).

The facility uses WHC-IP-0692, Health Physics Procedures Manual, Section 5.2.3.1, "Air Sample Exchange," for direction in choosing fliter media (WHC 1991a). This procedure requires use of a 3- $\mu$ m particle rated LB5211 or equivalent fiberglass filter. The 340 Facility currentiy uses Gelman Sciences, Inc., 3 um Versapor 3000* size 47-mm filters. Although 11sted as 3 mm filters, in a letter provided by Gelman Sciences, these fllters have shown a $91 x$ efficiency rating for particles of size 0.3 $\mathrm{mm}$ using ASTM 0 2986-71 Method (Gelman Sciences).

\subsection{Radionuclides as Gases.}

Samples are exchanged weekly as required by Health Physics Scheduled Radiation Survey Task Description for Bullding 340, Task No. J-W005, (WHC 1993). Procedure 5.2.3.1, "Air Sample Exchange," found in WHC-IP-0692, Health Physics Procedures Manual, provides the detalled instruction of how to accomplish a changeout (WHC 1993). This

*Trademark of Gelman Sciences, Inc. 
procedure discusses the use of charcoal cartridges used at the 340 Faclitty to sample radioactive lodine.

\begin{abstract}
2.2.1 The Radionuclide trltium (H-3). Tritlum in the form of water vepor le collected frem the extracted effluent sumple by sorption, condensation or dissolution technlques. Approprlote collectore may include sllica gel, molecular sleves, and ethyleme olycel or water bubblers.

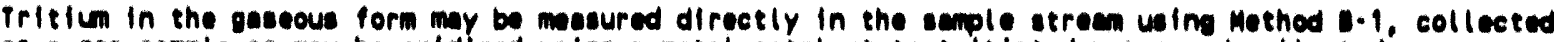
as a gas omple or may be oxldized using o matal catalyst to erltiated water and collected as deser l bad above.
\end{abstract}

Vault storage tanks get their radioactivity from the waste sent to thu facllity by Pacific Northwest Laboratory (PNL). Nork in the laboratories is not routine, instead varying with each project. Constituent type and volume recelved at the 340 Facillty also varfes with each project. Recently, PNL has been working with tritfum. To date, the 340 Faclilty has not evaluated the need to implement monttoring of trittum in the stack effluent.

2.2 .2 Redionucllose of lodine. Iodine ls collected from un extracted semple by sorption or diesolution techniques. Approprlate collectore my Include charcoal, Impreansted charcoal, matel zeollte and caustic solutions.

Vault storage tanks get their radioactivity from the waste sent to the facllity by PNL. Work in the laboratorles is not routine, instead varying with each project. Constituent type and volume received at the 340 Facllity also varles with each project. In the past, PNL worked with large quantities of radioactive lodine. Although this is no longer the case, the 340 Facllity continues to monitor for radloactive lodine using HI-Q Environmental Products, TEDA-Impregnated Carbon Cartridge for Adsorption of Radioactive Iodine.

2.2.3 Radionuclides of Argon, Krypton and Xenon. Radionuclidas of these el ements are lther measured directly by an in.line or off-line monltor, or are collected from the extracted semple by low temperature sorption technlques, Approprlate sorbers may include charcosl or matal 2001 te.

Vault storage tanks get their radioactivity from the waste sent to the facllity by PNL. Work in the laboratorles is not rout ine, instead varying with each project. Constituent type and volume received at the 340 Facility also varies with each project. Currently, PNL does not use radioactive argon, krypton, or xenon in any projects.

2.2.4 Radionucllades of Oxygen, Carbon, Nitrogen and Radon. Radionuclides of these ol ements ore measured directly using on in-line or off.l ine monitor. Radionucllades of carbon in the form of carbon dioxide may be collected by dissolution in caustic solutions.

Vault storage tanks get their radioactivity from the waste sent to the faclilty by PNL. Work in the laboratorles is not routine, instead varying with each project. Constituent type and volume recelved at the 340 Facllity also varies with each project. Currently, PNL does not use radioactlve oxygen, nitrogen, or radon in any projects. 
WHC-EP-0536-1

\subsection{Definition of Torme}

In-Unemoniter means a continuous masurement syatem in which the detector le placed directly in or adjecent to the effluont strean. Ihls may involve ol ther grose redlosctivity masurements or opacifle redionuclide measuremente. Orose meseurements shall be made in conformance with the conditions apecifled in Mothods $A \cdot 4,8-2$ and $0-4$.

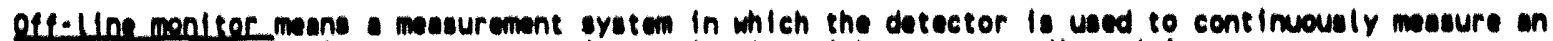
extracted semple of the offluent strean. Thle my involve ol ther grose redioactivity meaurewents or epecifle redionuclide mesurements. Orose mesurements oheil be mode in conformance with the conditlons apecleled in Mothode $A \cdot 4,8.2$ and 0.4 .

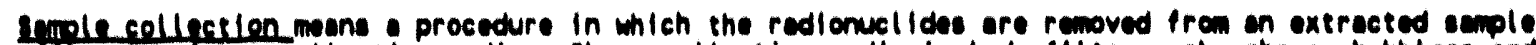
of the effluent using a collection media. These collection madie incluete fll ters, aboorbers, bubblers and condensers. The collected semple le analyzed using the mothods desecrlbed in section 3.0.

\subsection{Bedionualide Annlyale Merthode}

A series of methode based on "principles of mosurement" ore described which are applleable to the

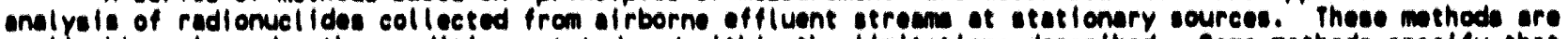
applicable only under the conditions stated and within the limitatione described. Some mathods apeclify that only a ingle redlonuclide be present in the semple or the chemically separeted sumple. Ihls condition should be interpreted to man that no other radionuclides are present in quntletes wilch would interfere with the mascurcment.

Also Identifled (table 1) are methods for a selected llat of redlonucl lase. The llated redionucl lades ore those unleh are most commonly used and whlch have the greatest potent lat for causing dose to membars of the publla. Use of mathods based on principles of masurement other than those describad In this aection must be approved in advance of use by the Adninletrator. For redionuclidas not lleted in table 1 , any of the deseribed methods may be used provided the user can demonstrate that the applicablilty conditlons of the method hove been mat.

The sype of method appllcable to the analysls of adlonuclide la dependent upon the type of rediation enltted, l.e., olphe, bete or gemma. Therefore, the mathode descrlbed below are grouped accerding to principles of masurements for the enalyels of alphe, bete and germe emiteing redionuclides.

\subsection{Mothods for Alphe Emltting Radionucllides}

\subsubsection{Method A-1, Redlochemlatry-Alphe spactrometry.}

Brincloles the element of Interest le separated from other elements, and from the eample matrix us ing radfochemical techniques. The procedure may involve preciplestion, ion exchange, or solvent extraction. Carriers (elements chemically similar to the element of interest) may be used. The element is deposited on a planchet in very thin fllm by electrodeposition or by coprecipitation on very anall amount of carrlor, such as lanthanum fluoride. The deposited element is then counted with an alphe spectrometer. The octivity of the nuclide of interest is masured by the number of alpho counts in the approprlate energy reglon. A correction for chemical yield and counting effletency lo made using standardized radioactive nuclide (tracer) of the same element. If a radionctive tracer is not avallable for the element of intereat, a predetermined chemical yield factor may be ueed.

Aoplleabilley: This method is epplicable for datermining the activity of any elpha-emitting radionuctide, regardtess of what other radionuclides are present in the semple provided the chemical separation step produces very thin semple and removes all other radionucildes inleh could interfere in the upectral reglon of Interest. APHA-605(2), ASTM-0-3972(13).

\subsubsection{Method A-2, Rediochemistry-Alphe Counting.}

Princioles The element of interest is separated from other elements, and from the semple matrix using radfochemletry. The procedure may involve precipitation, ion exchange, or solvent extraction. Carriore (elements chemically similar to the lement of interest) mey bo used. The element is daposited on a planchat in thin film and counted with olpha counter. A corraction for chemical viold (if neceseary) is made. The olphe count rate measures the cotal activity of all emitting radionuclides of the separated eloment.

Apollabbllisy: This method is applicable for the masurement of any alphe-emitting radionuclide, provided no other otphe emitting radionuclide is present in the separated sample. It may also be applicable for determining compllance, when other radionuclides of the separated element are present, provided that the calculated emission rate is aseigned to the radionuclide which could be present in the semple that has the highest dose conversion factor. 100-12096(18). 


\subsubsection{Method A-3, Direct Alphe spectrometry.}

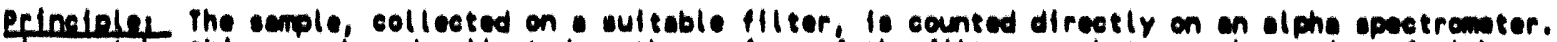
The anpte must to thin enough and collected on the eurfuce of the fllter wo that eny abuorpelon of olphe particle eneray in the semple or the fllter, whlch would dogrede the epectrum, is minimal.

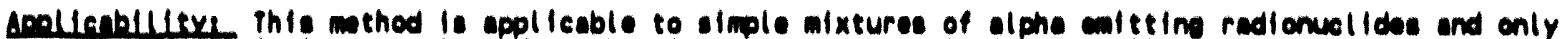
when the enount of particulates collected on the fllter paper are relatively anall and the elphe epectre le edequately resolved. Reselutions should be $30 \mathrm{keV}$ (IWHM) or better, AstM-0-3084(16).

\subsubsection{Mothod A=4, Direct Alpho Counting (orose alphe determination).}

erinciples. The semple, collected on oultable flleer, is counted with on olphe counter. The semple muat be thin enough so that self-absorption la not ignifleant and the fllter must be of such a nature that the particles are retained on the surface.

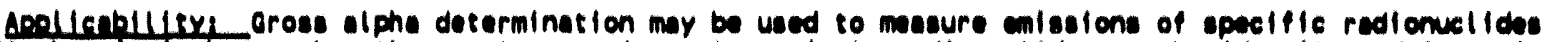
only (1) when it to known that the semple contelns only s ingle redionuclide, or the ldentity end leotople ratio of the redionuclides in the cemple are well known, and (2) masurements us ing ol ther wethod A-1, A.2

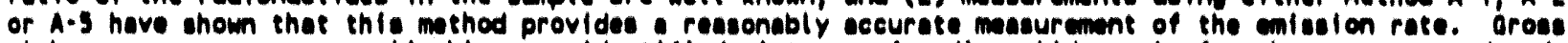
alphe maseuremente are appllable to unidentifled mixtures of radlonuclides only for the purposes ond under the conditions deseribed in section 3.7. APHA-601(3), ASTM-0.1963(10).

\subsubsection{Mothod A.5, Chemical Determination of Uranlun.}

Urenlemi Uraniun may be mosured chemically by el ther colorimatry or fluoremetry. In both procectures, the comple is dlasolved, the uraniun ls oxidized to the hexavalent form and extracted into aultable solvent. Imourlties are removed iros the nolvent laver. for colorimatry, dibenzoylmethene is added, and the

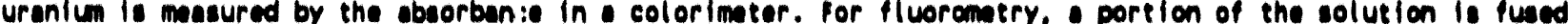
with a adium fluoride. Il thium fluoi. lde flux and the uranlum le datermined by the ultravlolet ectivated fluorescence of the fused disk in a fluorameter.

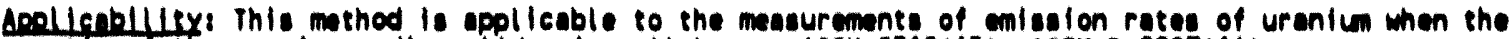
leotopic ratto of the uraniun redloriuclides is wall known. AstM-E318(15), AstM-0.2907(16).

\subsubsection{Method A-6, Aedon-222-Cont Inuous ans Monltor.}

eclacilales Redon-222 10 mensured direcely in a consinuously extracted semple strecm by paseing the

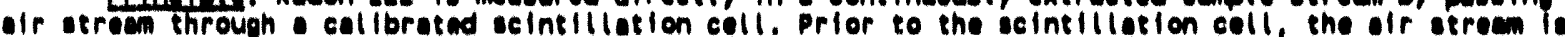
treated to remove pertlculates and excess moleture. The alphe particles from redon-222 and lte decay products strike. zine oulflde conting on the Inside of the ecintlliation cell producing llaht pulses. The

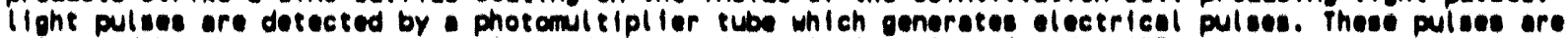
processed by the system electronics and the read out le in pCl/l of redon-222.

Apollanbllify: This mothod to opplicable to the mosurement of redon-222 in offluent stroame which do not contain signtflcant quantitles of radon-220. Users of this method should callbrate the monitor in radon calibration chamber ot least ewlce par year. The background of the monitor chould also be checked perlodically by operating the instrument in a low radon environment. EPA 520/1-89.009(26).

\subsubsection{Method A-7, Radon-222-Alphe Treck Detectors}

Pcinciple: Radon-222 lo masured directly in the offluent strean using alpha erack detectors (ATO). The al phe particles emitted by radon-222 and lts decey products strike e amall plestlc strlp and produce submicron damage tracks. The plestlc strip is ploced in a cauatic solution that accentuates the damage tracks which ore counted using a microscope or automatic counting avatem. The number of tracke per inte area is corrected to the redon concentration in air weing a converalon factor derived from date generuted in - radon callibration facllity.

Apollacelllty: Prlor approval from EPA is required for use of this mathod. This mathod is only appl lcable to offluent streans which do not contain significent quantitios of redon-220, unlese apacial detectors ore used to discriminate against ; adon 220. This method may be used only then atos have been demonstrated to produce date comparable to date obtained with Method A-6. Such data should be submitted to EPA when requesting approval for the use of this mathod. EPA $320 / 1 \cdot 89 \cdot 009(24)$.

\subsection{Methods for Gaseous Bate Emitting Radionuclides.}

\subsubsection{Mathad 8.1, Direct Counting in Flow-Through Ionization Chembers.}

erinciple: An lonizetion chamber containing apecific volume of gas which flowe ot oiven flow rate through the chamber is used. The semple (effluent stream sample) acts as the counting gas for the chember. The activity of the radionuclide le determined from the current measured in the ionization chember. 


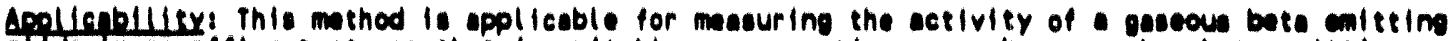

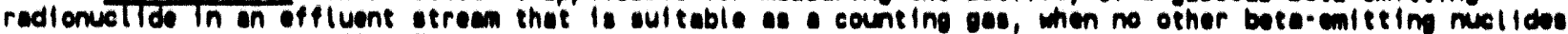
ore present. DoE/EP-0096(1 7), MCAP-58(23).

\subsubsection{Mothed 1-2, Direct Counting With in-line or oft-1Ine Dete Detectore.}

Reingloles the bete detector to pleced directly in the effluent utreem (in-line) or en extrected comple of the effluent atrecen la pased through chember conteining bate detector (off-line). The activities of the redionuclldes present in the effluent strean ore dotermined frem the bote coune rate, and - knowledge of the redionuclides present and the relationahip of the orose bete count rate and the apecifle radionuclide concentration.

Amollatbllity: Thls method lo applicable only to radionuclides with maximu bete particle meroles

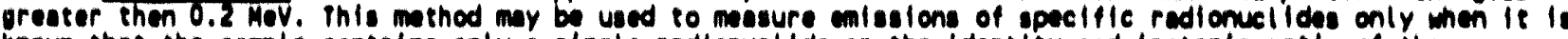
known that the semple conteins only. single redionuclide or the identity and leotople retlo of the redionuclides in the effluent strean are woll known. spacifle radionucllade analyals of perlodic orab semples may be used to Identlfy the types and quantities of radionuclides present and to establish the relationahip between specifle redionucllde analyees and grose bete count rates.

Thls method is applicable to unldentifled mixtures of soscowe redlonuclides only for the purposes end under the conditions desertbed in section 3.7.

\subsection{Methods for Mon Caseous bete Emitting Medionuclides,}

\subsubsection{Me: iod 1-3, Rodiochemistry-Bete counting.}

erjnciples the element of interest is eoparated from other elemente, and from the semple matrix by redlochemistry. This may involve precipltation, distlllation, ion exchange, or colvent extroction. Carriere colements chemically aimilar to the olemant of interest) may be uad. The element is deposited on a planchet, and counted with a bete counter. Correctlons for chemlcal yield and decay (lf necessery) are made. the bete count rate determines the total ectivity of all radionuclldes of the separeted element. Thise method mav also involve the radlochemical separation and counting of a daughter element, ofter sultable pariod of ingrowth, in which case it la specifle for the parent nuclide.

Aoollablulty: Thle method is applicable for mensuring the ectivity of ony beta.emltting radionuctide, wth a maximum enerey oreater then 0.2 Mov, provided no other radionucllde lo present in the separated semple. APHA-608(5).

\subsubsection{Method B.4, Olrect Beta Counting (Oross bete determination).}

erincloles the oumple, collected on eultable fllter, lo counted with a bate counter. The semple mast be thin enough so that self-ubsorption corrections can be made.

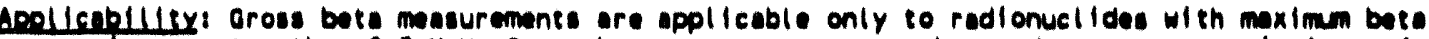
partlele energtes oreater than 0.2 MeV. Grose bete measurements may be used to masure emlestone of apectifle radionuclides only (1) when it le known that the sample conteins only o ingle radionuclide, and (2) mesesurements made using Mothod 8.3 show reasonable egrecment with the grose bete measurement. Orose bete measurements ore applicable so mixtures of radionuclides only for the purposes and under the conditions described in section 3.7. APHA-602(4), AsTM-0.1890(11).

\subsubsection{Mothod B.5, Llquid scintlllation spactrometry.}

Principle: An ellquot of a collected semple or the result of some other chemical separation or proceseing technique is added to a llquid ecintillation "cocktall" thich is viewed by photomultiplier tubes in : llquid scintillation spectrometer. The spectrometer is adjusted to establish ochannel or "window" for the pulse energy epproprlate to the nuclide of interest. The activity of the nucllde of interest is measured by the counting rate in the appropriate energy channel. Corrections are made for chemical yield there separations are made.

Apollagbllify: Thls method is applicable to any beta-emitting nuclide when no other radionuclide is present in the sempte or the seperated sample provided that it can be incorporated in the scintillation cocktall. This method is also applicable for semples which contain more then one redionuclide but only when the energies of the bete partlcles ore sufflciently separoted so that they can be resolved by the spectrometer. This method is most applicable to the measurement of low.energy bete enltters such as tritiun and carbon-14. APHA.609(6), EML เV. $539 \cdot 17(19)$. 
WHC-EP-0536-1

\section{4 aeme Enitting Redionucl ldes}

\subsubsection{Mothod 0.1. Mlah Resolution Oenme spactronstry.}

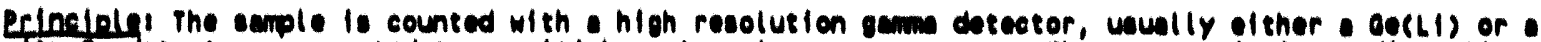

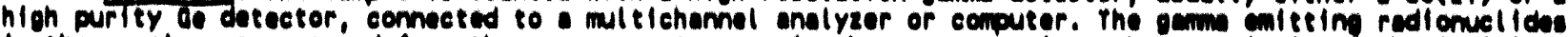
In the ecmple ore masured from the garms count rates in the emergy reglons cherecterletle of the individunl redianuclide. Corrections are mede for counts contributed by other redionuelldes to the epectral reglons of the redionucilides of interest. Redlochemical separations may be made prifor to counting but are ueuwlity not neceseary.

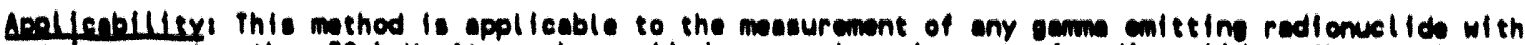

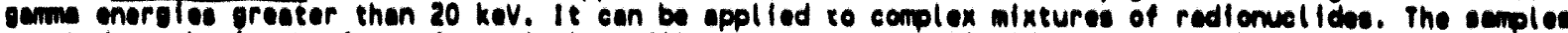
counted may be in the form of particulate fllters, absorbers, llquids or gasees. The mathod may also be

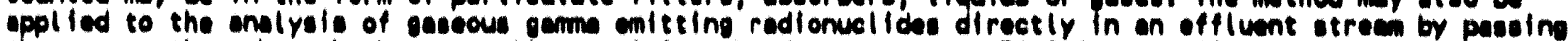
the strean through a chember or cell contelning the detector. AstM-3649(0), 100-120\%6( 18$).$

\subsubsection{Method 0.2, Low Resolution Gamme spectronetry.}

Erinciples the semple is counted with " low resolution gemm detector, e thalliun activoted sodium lodide cryotal. The dotector is coupled to o photomultiplier tubs and comected to a multichamel analyzer. The gamm emleting redionuclldes in the semple ore measured fron the gemm count rates in the eneroy reglons characterletle of the individual redionuclides. Corrections are mede for counte contributed by other redionuclldes to the apectral reglons of the radionuclides of Intereat. Redlochemical separation may be used prlor to counting to obtain lese complex ganm spectre if needed.

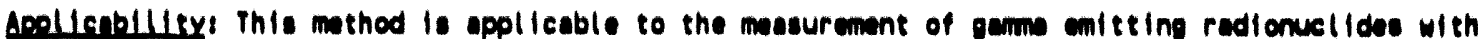
energles prester then $100 \mathrm{keV}$. It can be applied only to relotivoly simple mixtures of gemm emltting radionuclides. The semples counted may be in the form of partlculate fllters, absorbere, liquide or gas. The method cen be applled to the andyele of gaseous radlonucllades directly in on effluent otrean by paseing the gas stream through a chember or cell containing the detector. AstM-0-2459(12), EMBL-LV-0539-17(10),

\subsubsection{Method 0.3, single Channel Oarmu spectrometry.}

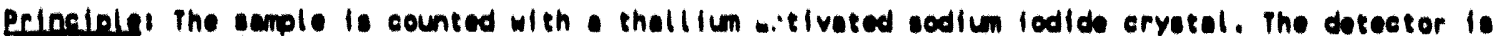

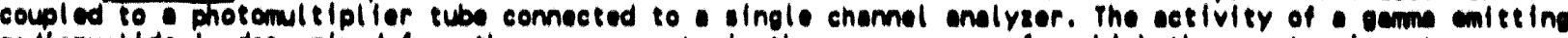
radionvelide lo doterminad from the gamm counte in the energy range for which the counter lo set.

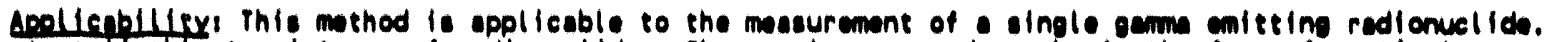
It is not appltcabte to mixtures of radlonuclides. The samples counted may be in the form of parelculate fllters, absorbers, llquide or gas. The mathod cen be applled to the enalys is of gaseous radlonucl ldes diractly in an effluent stream by passing the gas stream through a chember or cell containing the dotector.

\subsubsection{Method 0.4, Grose Ganme Counting.}

Erinciple! the sample is counted with gamm detector usually a thallium activeted sodiun lodine crystal. The detector is coupled to a photomultipller tube and ganma rave above apecifle threshold energy lovel are counted.

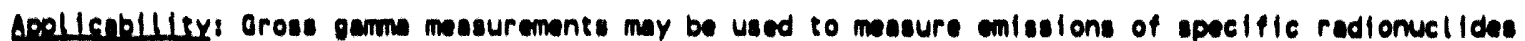

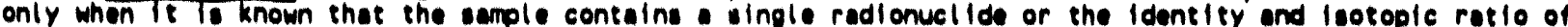
the radionuclides in the effluent stream ore woll known. When grose gemme mensur monte ore used to dotermine emiselons of epecifle radionuelides perlodic measurements using Methods 0.1 or 0.2 thould be made to demonstrate that the grose gamm masurements provide rallable emiseston data. Thls mathod may be applled to analyels of geseous redionuclides directly in an effluent strean by placing the detector directly in or adjacent to the offluent strean or passing an extracted sample of the effluent strean through ochember or cell contelning the detector.

3.5 Counting Mothods. All of the methode with the exception of Mathod A.5 involve caunting the radiation emitted by the radionuclide. Counting mathods appll cable to the meesurement of lphe, bete and gemm radiatione are lleted bolow. The equipment noeded and the count ing principlos involved are described in datall in AsTM-3648(8).

\subsubsection{Alphe Counting:}

- ans loy proportlonal counters. The alphe particles cause lonizotion in the counting gas and the resulting etectrtest putses ore counted. These counters may be windowless or have very thin windows.

escintlllation counters. The olpha particles tranafer energy to scintlllator resulting in production of that photons which strike photomultiplier tube converting the light photons to electrical pulses which ore counted. The counters may involve the use of solid scintillation materials such as zinc sulfide or llquid seintillation solutions. 


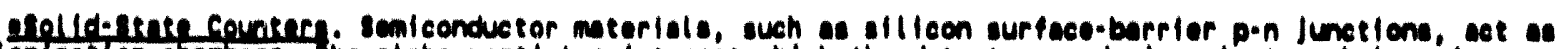
solld lontzotion shembers. The alphe partlcles interact whlch the detector producing electron hole pelre. The chareed poir lo collected by an applled electrleal fleld and the resulting olectrical pulses are counted.

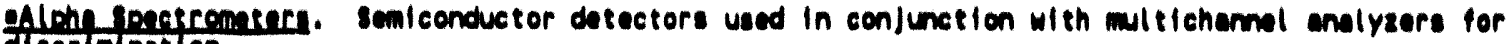
eneray drecrimination.

\subsubsection{Bete countings}

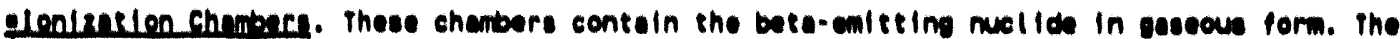
lonlzotion eurront produced is mesoured.

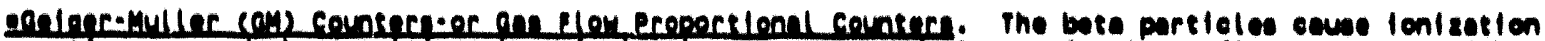

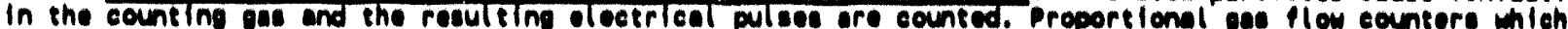
ore heavily ahlelded by lead or other matal, and provlded with an entl-colneldence ehleld to rejeet eocale raye, ore called low background beta counters.

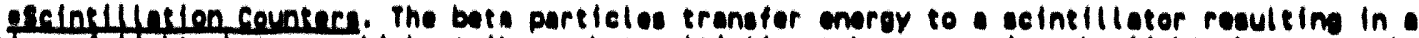

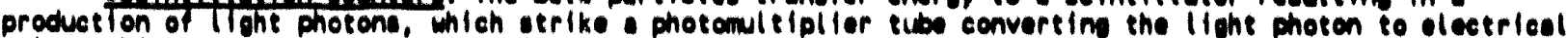

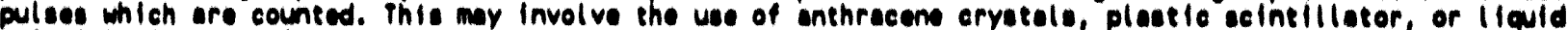
seintillation solutions with organle phosphors.

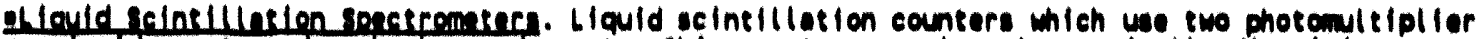

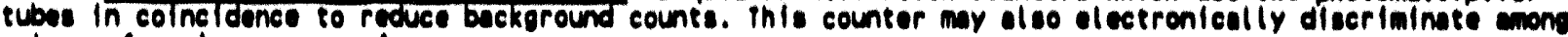
pulses of olven range of energy.

\subsection{3 coum Countings}

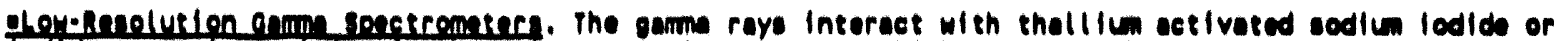
ceslum lodide cryotel resulting in the retese of lloht photons mich strike photcmultipller tube eonvert. Ing the lloht pulses to slectrieal pulses proportlonal to the energy of the gamm ray. Mulel-chamel analyzere ore used to espersete and store the pulses according to the enerey absorbed in the cryatal.

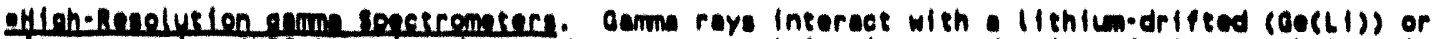
high-purfey germantum (Hpae) omfeonductor detectors resulting in production of electron-hole pelre. ihe

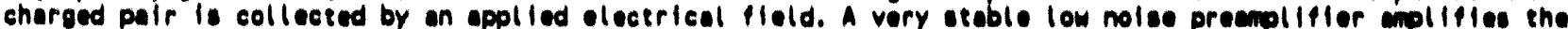
pulses of electrical charge reauleing from the gemm photon interactions. Multichamel inolveers or computers ore used to separate and store the pulsese sccording to the enoroy abserbed in the cryetal.

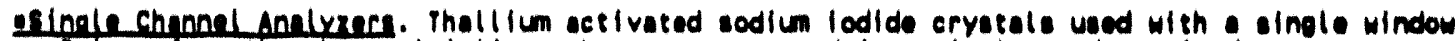
analvzer. putses from the photomultiplier tubes ore separated in a ingle predetermined enerey renge.

3.5.4 Callbration of Counters. Counters are callbrated for apeciflic radionuclide mesurements uaing a standard of the radionuclide under ither Identical or very similar conditions as the semple to be counted. for parme spectrometers a series of standards covering the energy range of interest may be used to construct - callbretion curve relating gamm energy to counting effliclency.

In those cases where stendard to not avallable for a redionucllda, counters may be callbrated using - standard with energy cheracteristics as simllar as possible to the redionuclida to be mansured. for groses alpha and bete masurements of the unldentifled mixtures of radionuclides, alphe counters are calibreted with natural uranium standerd and bete counters with ceslum-137 atanderd. The atendard must contein the same wolght and diseribution of solids os the samples, and be mounted in en identical marmer. If the semples contain variable anounts of sollds, calibrotion curves relating wolght of solids present to counting effleciency are prepared. standarde other than those proserlbad may be used provided it can be shown that such standards are more appl leable to the radlonuclide mixture masured.

3.6 Radiochemical Methode for selected Radionuclides. Mathode for a selected list of radionuclidee ore lleted in Table 1. The redionuclides listed ore those which are nost conmonly used and whlach hove the oreatest potential for causing doses to members of the public. For radionuclides not liseted in iable 1 , methode based on any of the epplicable "princlples of masurement" describad in section 3.1 through 3.4 may be used.

3.7 Applicabillity of Orose Alphe and Bete Messurements to Unidentified Mixtures of Radlonuclidas. Gross alphe and beta masurements may be used as a screening masurement as a pert of an emisesion messurement program to identify the need to do specifle radionuclide analyese or to confirm or verify that unexpected radionuclides are not being released in significant quantities.

aross alphe (Method A-4) or gross bete (Methods 8.2 or 8.4) masurements may also be used for the purpose of comparing the measured concentrations in the effluent streen with the limiting "Concentration Level for Environmental Compliance" in Table 2 of Appendix E. For unidentified mixtures, the messured 
concentration value shall be compared with the lowest environmental concentration limit for any radionuclide which is not known to be absent from the effluent strean.

See Appendix H.

\subsection{Quality Assurance Methods}

Each facility required to measure their radionuclide emissions shall conduct a quality assurance program in conjunction with the radionuclide emission measurements. This program shall assure that the emission measurements are representative, and are of known precision and accuracy and shall include acministrative controls to assure prompt response when emission measurements indicate unexpectedly large emissions. The program shall consist of system of policies, organizational responsibilities, written procedures, data quality specifications, audits, corrective actions and reports. This quallty assurance program shall include the following program elements:

4.1 The organizational structure functional responsibilities, levels of authority and lines of communications for all activities related to the emissions mosurement program shall be identified and documentid.

4.2 Administrative controls shall be prescribed to ensure prompt response in the event that enission levels incresse due to unplanned operations.

WHC-C,M-4-12, Part B, Section 1.14, "Alarm Response and Management." Establishes requirements and provides guidance for responding to alarms that are the responsibility of Health Physics (HP).

WHC-CM-4-12, Part A, Section 2.1, "Radiological Problem Reporting Program." The purpose of the Radiological Problem Report (RPR) program is to provide a documented record of observed radiological problems, a mechanism for reporting these problems to management for action, a capability to track and monitor the progress of the planned corrective actions, and a database for assessing trends in radiological program performance and needed actions.

WHC-CM-4-12, Part B, Section 12.1, "Emergency Response." An Emergency is a sudden unexpected event requiring immediate response to mitigate impacts to people, property, or the environment. When radioactive material is involved, Health Physics (HP) plays a major role in evaluating, controlling, and recovering from the event. To perform this function, HP personnel receive training to respond to a variety of emergency situations. All HP procedures provide emergency response guidelines. Together, the training and the written procedure detail the HP Emergency Response Program.

Emergency Response. In many situations HP personnel are the first to respond to a radiological emergency. The ability to assess and eva'uate the situation and take immediate steps to minimize the effects of the event is crucial for controlling the emergency. The HP personnel must use their training and experience to make good decisions during the initial response to an emergency.

An emergency response may be initiated by personnel observing the event, alarms, the Patrol operation Center, or the Emergency Control Center(s) once they are manned. For a planned response, HP personnel shall be in teams of at least two. Out of necessity (e.g., backshift response), one member could be an Operations person or other emergency service person such as fire or patrol. A rapid response is required; however, no undue risks should be taken nor

$$
\text { F }-10
$$


should employee personnel safety be compromised. The type of emergency determines the level of planning for HP response. For example, a continuous air monitor (CAM) alarm or a small radioactive spill requires little planning for the initial response. However, when an emergency causes a facility evacuation, preplanning (e.g., stay time, entry route) by and approval of the Building/Facility Emergency Director are necessary for re-entry.

Although HP personnel respond to an emergency using basic guidelines, an area/facility may have specific procedures that have priority over these guidelines.

WHC-IP-0692, Section 12.1.2.3, "Effluent Exhaust CAM Alarm Response." This procedure establishes the standard method of handling samples from, and response to alarms at, Effluent Exhaust CAM systems. This procedure describes the steps and material necessary to exchange, perform field concentration calculations, and submit suspect samples for "rush" or "Red Envelope" analysis when responding to alarms on Effluent Exhaust CAM systems.

WHC-IP-0692, Section 12.1.6, "Stack Effluent Release Response." This procedure establishes guidelines for responding to a potential or actual release of radioactive material through exhaust stacks. This procedure describes the immediate actions to respond to an exhaust (CAM) stack al arm (i.e., CAM monitoring downstream or upstream of the final filtration).

WHC-IP-0692, Section 12.2.1, "Emergency Response Air Sampling." This procedure establishes the instruction and guidelines for air sampling in an emergency situation. This procedure describes the steps for air sampling both inside and outside facilities when a release of radioactive material is suspected.

WHC-IP-0692, Section 12.2.3, "Health Physics Emergency Response Team." This procedure provides the organizational structure of, the instructions for, and the responsibilities of the HP Emergency Response Team and the Radiation Protection Technologist (RPT) Field Survey Teams. This procedure describos the steps for an initial emergency response by the HP Emergency Response Team (ERT) and RPT Field Survey Teams. The HP ERT and the RPT Field Survey Teams may be requested to respond to an emergency when it is deemed that an environmental release of radioactive material may extend beyond the control of a facility or outside the boundaries of the Hanford ite. These teams will have monitoring responsibilities only outside the boundaries of the event site.

WHC-IP-0692, Section 12.2.4, "Emergency Radioactive Plume Tracking." This procedure establishes the instructions to track a plume created from a radioactive material release to the environment. This procedure describes the steps to track and to determine if a radioactive beta-gamma plume is at ground level or at an elevated level.

Notifications and reporting of specific events related to environmental releases and/or events involving effluents and/or 
hazardous materials are reported via instruction given in WHC-CM-5-34 (WHC 1991C), Solid/Liquid Waste Remediation Operations Administration, Section 1.18, "Occurrence Reporting and Processing of Operations Information." The purpose of this procedure is to establish and implement specific criteria and requirements for the identification, categorization, notification, and reporting of occurrences within the Solid/Liquid Waste Division, including the 340 Facility, as required by WHC-CM-1-3 (WHC 1990b), MRP 5.14, "Occurrence Reporting and Processing of Operational Information."

4.3 The sample collection and analysis procedures used in measuring the emissions shall be described including where applicable:

4.3.1 Identification of sampling sites and number of sampling points, including the rationale for site selections.

Drawing H-3-34406 (DOE-RL 1978), "HVAC Elevations, Sections and Details," shows stack dimensions and: nling site location. As shown, the stack is $18 \mathrm{in.} \mathrm{In} \mathrm{diameter.} \mathrm{sample} \mathrm{site} \mathrm{is} \mathrm{located}$ $10 \mathrm{ft}$ downstream (or 6.6 duct diameters). Wo the last disturbance and $2 \mathrm{ft}$ (or 1.3 duct diameter) from the point of release. This location meets the criteria specified in 40 CFR 60, Appendix $A$, Method IA (EPA 1991).

The sample probe was designed and installed by Air Monitor Corporation (AMC). The Certified Vendor Information, CVI-30256, Operating and Maintenance Manual for the 300 Area Radloact ive Liquid Waste System (Air Monitor Corporation), contains the probe design drawings and a detailed explanation of how American National Standards Institute (ANSI) standards are applied. To summarize here, the stack has one sample probe with eight sample nozzles. The AMC sampling unit uses an air profiling station to produce a flat velocity profile of non-rotating, straight air. This allows for isokinetic sampling and measuring the stack velocity and volume under almost any condition of airflow.

\subsubsection{A description of sampling probes and representativeness of the samples}

The sample probe was designed and installed by AMC. The CVI-30256 contains the probe design drawings and a detailed explanation of how ANSI standards are applied. To summarize here, the stack has one sample probe. It has 20 total pressure sensors, 4 static pressure sensors, and 8 sample nozzles. The inside diameter of each nozzle is $0.58 \mathrm{in}$. and each covers $0.224 \mathrm{ft}^{2}$ of area. The AMC sampling unit uses an air profiling station to produce a flat velocity profile of non-rotating, straight air. This allows for isokinetic sampling and measuring the stack velocity and volume under almost any condition of airfiow. 
4.3.3 A description of any continuous monitoring system used to measure emissions, including the sensitivity of the system, calibration procedures and frequency of calibration.

Not applicable; emissions are not monitored continuously for compliance purposes.

4.3.4 A description of the sample collection systems for each radionucl ide masured, including frequency of collection, callibration procedures and frequency of callibration.

The sampler runs continuousiy to ensure a representative sample. Radioactive particulates are captured on a high-efficiency particulate air filter as described in Section 2.1 of this document. Radioactive lodine is captured on a charcoal cartridge as described in Section 2.2.2 of this document. Samples are collected weekly, in accordance with procedures WHC-IP-0692, Health Physics Procedures Manual, Section 5.2.3.1, "Air Sample Exchange" (WHC 1991a), and Health Physics Scheduled Radiation Survey Task Description for Building 340, Task No. J-WOO5, (WHC 1993). There are no calibrations required for the particulate filter or the charcoal cartridge.

4.3.5 A description of the laboratory analysis procedures used for each redionuclide measured, including frequency of analysis calibration procedures and frequency of calibration.

Laboratory analysis procedures used for Stack 340-NT-EX record samples are described by the information in Appendix $H$.

4.3.6 A description of the sample flow rate measurement systems or procedures, including calibration procedures and frequency of callibration.

The sample flow rate is regulated using a rotameter provided by Dwyer Instruments. These rotameters are described in Certified Vendor Information CVI-30268, "Flowmeters," model number RMA-9-TMV (Dwyer Instruments). The visual float is verified weekly during sample collection in accordance with WHC-IP-0692, Health Physics Procedures Manual, Section 5.2.3.1, "Air Sample Exchange." Rotameters are scheduled for calibration annually. The calibration is completed in accordance with Calibration Procedure 1148, "Calibrate Rotameter" (Becken 1990). 4.3.7 A description of the effluent flow rate measurement procedures, including frequency of
measurements, calibration procedures and frequency of calibration.

The flow measurements for Stack 340-NT-EX are required annually at a minimum in accordance with the 300 Area Maintenance Engineer Services procedure \#1135. A pitot tube is inserted into a test port to measure the velocity pressure, which is then converted to flow using a table and equation from the data sheet for the procedure. 
4.4 The objectives of the quality assurance progran shall be documented and shall state the required precision, accuracy and completeness of the emlssion measurement date including description of the procedures used to assess these parameters. Accuracy is the degree of agreement of measurement with a true or known value. Precision is measure of the agreement anong individual measurements of the seme parameters under similar conditions. Completeness is a measure of the unount of date obtained compered to the anount expected under normal conditions.

The objectives of the quality assurance program will be described in a future Environmental Protection Quality Assurance Project Plan.

4.5 A quality control progrem shall be established to evaluate and track the quality of the emlaslons measurement data against preset criteria. The progran should include where applicable syatem of replicates, spiked samples, split samples, blanks and control charts. The mumer and frequency of such quality control checks shall be identified.

\section{Laboratory requirements are presented in Appendix $H$.}

4.6 A sample tracking system shall be established to provide for positive identification of semples and data through all phases of the sample collection, analysis and reporting system. Semple handling and preservation procedures shall be established to maintain the integrity of semples during collection, storage and analysis.

\section{See Section 6.2 .3 of the main body of this report.}

4.7 Periodic internal and external audits shall be performod to monitor compliance with the quallty assurance program. These audits shall be performed in accordance with written procedures and conducted by personnel who do not have responsibility for performing any of the operations being audi ted.

\section{See Section 7.0 of the main body of this report.}

4.8 A corrective action program shall be established including criteria for when corrective action is needed, what corrective action will be taken and who is responsible for taking the corrective action.

See Section 8.0 of the main body of this report.

4.9 Periodic reports to responsible management shall be prepered on the performance of the emissions messurements program. These reports should include assessment of the quality of the data, results of audits and description of corrective actions.

See Section 9.0 of the main body of this report.

4.10 The quality assurance program should be documented in a quality assurance project plan which should address each of the above requirements.

The quality assurance program for stack 340-NT-EX will be described in a future Quality Assurance Project Plan. 


\section{REFERENCES}

Air Monitor Corporation, Operating and Maintenance Manual for 300 Area Radioactive Liquid Waste System, Air Monitor Corporation, Santa Rosa, California.

Becken, G.W., 1990, Maintenance Engineering Services "Calibration Procedure," Procedure 1148, Rev. 0, Westinghouse Hanford Company, Richland, Washington.

DOE-RL, 1978, "HVAC Elevations Sections and Details," Drawing No. H-3-34406, U.S. Department of Energy-Richland Operations Office, Richland, Washington.

Dwyer Instruments, "Flowmeters: Rate-Master Serles and Visi-Float? Series," Bulletin F-41, Dwyer Instruments, Inc., Michigan City, Indiana.

EPA, 1991, "Standards of Performance for New Statlonary Sources, "Title 40, Code of Federal Regulations, Part 60, U.S. Environmental Protection Agency, Richland, Washington.

Gelman Sciences, Internal Memo from Karol Butcher, Gelman Sciences, to Carter Kirk, Westinghouse Hanford Company, re: Versapor 3000, DOP Efficiency, dated October 31, 1991.

WHC, 1990a, Health Physics Practices Manual, as amended, WHC $. M-4-12$, Westinghouse Hanford Company, Richland, Washington.

WHC, 1990b, Management Requirements and Procedures, as amended, WHC-CM-1-3, Westinghouse Hanford Company, Richland, Washington.

WHC, 1991a, Health Physics Procedures Manual, WHC-IP-0692, Westinghouse Hanford Company, Richland, Washington.

WHC, 1991b, Health Physics Scheduled Radiation Survey Task Descriotion for Building 340, 300 Area, Task No. J-W005, Westinghouse Hanford Company, Richland, Washington.

WHC, 1991c, Solid/Liquid Waste Remediation Operations Administration, WHC-CM-5-34, Westinghouse Hanford Company, Richland, Washington. 
WHC-EP-0536-1

This page intentionally left blank. 
WHC-EP-0536-1

APPENDIX 6

METHOD 114 COMPARISON FOR THE 222-S LABORATORY

A. K. Dasgupta 
WHC-EP-0536-1

This page intentionally left blank. 
WHC-EP-0536-1

APPENDIX 6

METHOD 114 COMPARISON FOR THE 222-S LABORATORY

Emissions monitoring practices for the following Hanford site main stacks are evaluated for compllance with the radionuclide emission requitrements defined in Title 40 Code of Federal Regulations (CFR) Part 61, Subpart H, "National Emtssion Standards for Hazardous A1r Pollutants" (NESHAP)

(EPA 1991):

a. 291-A-1--Plutonfum-Uranfum Extraction (PUREX) Plant Main Exhaust Stack

b. 291-B-1--B Plant Main Stack

c. 291-2-1--Plutonium Finishing Plant Main Stack

d. 296-A-22--242-A Evaporator

e. 296-A-40--241-AP Tank Exhaust, Tank Farm

f. 340-NT-EX--Waste Handling Facility.

The effluents from each of these stacks are well characterized. The characterizations of radionuclide composition in emissions are in complete agreement with the operations carried out in respective facllittes generating radioactive emissions. Samples of emissions are collected from the stacks having the potential to contain the radionuclides given in Table G-1 in concentrations at the stack exits that may exceed 10\% of any of the Derived concentration Guides values provided in DOE Order 5400.5 (DOE 1990). The samples from stacks a through above are delivered to the 222-5 Laboratory and analyzed for each of the radionuclides listed in Table G-1.

The laboratory receives weekly or dafly main stack air fllter samples from the facilittes. They are usually $47-\mathrm{mm}$ fliters (acrylic copolymer on nylon), except from PUREX where 5-1n. $(127-\mathrm{mm})$ fliters are used. Before analys is is performed, samples are held for 7 days so that radon/daughters, if present in the fliters, can decay away.

The emissions collection media, sodium hydroxide, bubbler and silica gel, are used only at the PUREX main stack for collecting ${ }^{14} \mathrm{C}$ and ${ }^{3} \mathrm{H}$, respectively, and are sent biweekly to the laboratory for analysis.

The radionuclides ${ }^{131} \mathrm{I},{ }^{129} \mathrm{I},{ }^{103} \mathrm{Ru},{ }^{106} \mathrm{Rh},{ }^{113} \mathrm{Sh}$, and ${ }^{125} \mathrm{Sb}$ are monitored at the PUREX, 242-A Evaporator, and AP Tank Farm main stacks. Samplas are collected using silver zeolite cartridges that are sent weekly to the laboratory for identification of radionuclides and determination of their activity.

After a 7-day decay period, the total alpha/total beta activity concentrations in the weekly and daily air particulate samples are determined (procedure LA-508-110). This screening process is performed to make a quick evaluation of activity levels in the main stack air streams. If the activity level for a specific main stack is found to be significantly increased, as 
Table Q-1. Radionuclides

\begin{tabular}{|c|c|c|c|c|c|c|}
\hline $\begin{array}{l}\text { Nuclides } \\
\text { requested } \\
\text { for } \\
\text { analys is }\end{array}$ & $\begin{array}{c}\text { PUREX } \\
291-A-1\end{array}$ & $\begin{array}{l}B \text { P P ant } \\
291-B-1\end{array}$ & $\begin{array}{l}\text { Z-P1 ant } \\
291-z-1\end{array}$ & $\begin{array}{c}242-A \\
\text { Evaport. } \\
296-A-22\end{array}$ & $\begin{array}{c}241-A P \operatorname{tank} \\
296-A-40\end{array}$ & $\begin{array}{l}T \text { Plant } \\
291-T-1\end{array}$ \\
\hline $\begin{array}{l}\text { Alpha } \\
\text { Emittor }\end{array}$ & $\begin{array}{l}A M-241, \\
P U-238, \\
P U-239 \\
P U-240\end{array}$ & $\begin{array}{l}A n-241, \\
P u-238, \\
P u-239 \\
P u-240\end{array}$ & $\begin{array}{l}A m-241 \\
P u-238 \\
P u-239 \\
P u-240\end{array}$ & & & $\begin{array}{l}I I-241, \\
P u-238, \\
P u-239 \\
P u-240 \\
\end{array}$ \\
\hline $\begin{array}{l}\text { Beta } \\
\text { Emitter }\end{array}$ & $\begin{array}{l}r-89 \\
S r-90 j \\
Y-90, \\
P m-147, \\
C-14: H-3 \\
\text { (ges) } \\
\end{array}$ & $\begin{array}{l}S r-89 ; \\
S r-90 ; \\
Y-90\end{array}$ & & $\begin{array}{l}S r-19, \\
S r-90 / Y-90\end{array}$ & $\begin{array}{l}S r-89 \\
S r-90 / Y-90\end{array}$ & \\
\hline $\begin{array}{l}\text { Gamma } \\
\text { emitter(o) }\end{array}$ & \begin{tabular}{|l|}
$N b-95$, \\
$2 r-95 ;$ \\
$C s-134$, \\
$C s-137^{\prime}$ \\
$C \theta-144$ \\
$I-129^{(b)}$ \\
$I-131^{(b)}$ \\
$R h / R u-106^{(b)}$ \\
$R u-103^{(b)}$ \\
$S n-113^{(b)}$ \\
$S b-125^{(b)}$
\end{tabular} & \begin{tabular}{|c|} 
Cs-134 \\
Cs-137
\end{tabular} & & $\begin{array}{l}C s-134 \\
C s-137 \\
1-129^{(b)} \\
1-131^{(b)} \\
R h / R u-106^{(b)} \\
R u-103^{(b)} \\
\text { Sn-113(b) } \\
\text { Sb-125(b) }\end{array}$ & $\begin{array}{l}C s-134 \\
C s-137 \\
I-129^{(b)} \\
I-13 I^{(b)} \\
R h / R u-106^{(b)} \\
R u-103^{(b)} \\
S n-113^{(b)} \\
S b-125^{(b)}\end{array}$ & \\
\hline $\begin{array}{l}\text { Gross } \\
\text { Activity }\end{array}$ & $T A / T B(C)$ & $T A / T B$ & $T A / T B$ & $T A / T B$ & $T A / T B$ & TA/TB \\
\hline
\end{tabular}

(a) The gamma spectroscople techntque is used for analyses of these radionuclides because they ent gamma rays of high intensity.

(b) These radionuclides are collected on sllver zeolite sampling media.

(c) Total alpha and total bota analysis. 


$$
\text { WHC-EP-0536-1 }
$$

Indicated by 1ts total alpha/total beta data, then facflity personnel are contacted to alert them of a change in emissions. It is important to note here that continuous process control afr monitoring systems with alarms are Installed at each main stack for noar real-time response to elovated releases. These alarms will allow rapld response from factlity personnel if the situation warrants. For compliance, the screening of weekly total alpha/total beta measurements is made assuming the most ilmiting alpha pyrticulate (23, $240 \mathrm{Pu}$ ) and the most 1 imiting bota-emitting radionucilde (" $S r)$ in the Hanford Site stack offluents. To ensure conservat1sm, the 222-5 Laboratory performs spectfic radionuclide analyses on a composite of all filters collected during a calendar quarter. Gamma energy analys is (GEA) is performed (LA-508-052) on the composite to determing the actfuittes of the garme emitters, particularly ${ }^{65} \mathrm{Nb},{ }^{85} \mathrm{Zr},{ }^{\mathrm{B}} \mathrm{Cs},{ }^{\mathrm{B}} \mathrm{Cs}$, and ${ }^{14} \mathrm{Ce}$.

After GEA is complete, the quarterly compostte of air fllters is ashed, dissolved/leached, then appropriately treated and mounted for analysis of Individual alpha emitters (LA-549-112 [dissolution], LA-943-123 [chemical separation] LA-5435-101 [electrodeposition], LA-508-051 [al pha spectrometry] for ${ }^{24} \mathrm{Am},{ }_{30 \mathrm{Pu}},{ }^{25,} 26 \mathrm{Pu}$ ) and beta emitters (LA-549-112 [dissolution], 1A-220-103 [chemical separation], LA-608-11] [total bota counting] for ${ }^{6} .90 \mathrm{Sr} /{ }^{90} Y_{;}$LA-549-112 [dissolution], LA-613-11] [Chemical soparation], LA-548-11] [moynting in scintillation cocktal1], LA-508-121 [scint11lation counting] for $\mathrm{Pm}$ ), depending on the type of analyses requested by the factlity and 200 Areas Environmental Protection group.

Biweekly gas samples from the PUREX main stack collected in sodium hydroxide bubblers and silica gel are analyzed for " $C$ (LA-348-10] [chemical separation], LA-548-111 [mounting in cockta11], LA-508-12] [scintillation counting]) and for ${ }^{3} H$ (LA-218-112 (processing], LA-548-111 (mounting in

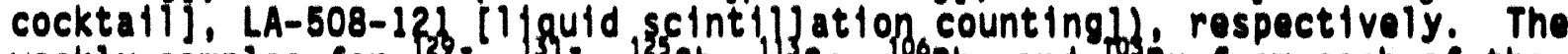

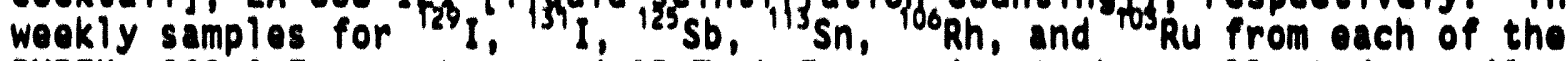
PUREX, 242-A Evaporator, and AP Tank Farm main stacks, collected on stlver zeolite cartridges, are analyzed by the GEA (LA-288-101 in conjunction with LA-508-J52).

A point-by-point comparison of analyses performed with the regulatory requirements of 40 CFR 61, Subpart $H$, Method 114 (particularly Sections 3 and 4 as applicable to 222-S Laboratory operations) (EPA 1991) is provided in the attachment. 
MerHoo 114 - iest methoos ron measuntho RAOIONUCLIDE EMISSIOWS PROM STAPIOWARY souncts

\section{0 eureorened lnakncound}

Thls methed provldes the requircmants for: (1) stack monltoring and somple collectlon mathode approprlate for redlonuclldes; (2) rediochemical methode wich ore used in determining the enounts of redionvelldes collected by the stack sumpling and; (3) aullty aseurance me thods whlch ore conducted in confunction wlth these meseurements. These methods ore approprlate for colleslons for statlonary sources. A llis of references is provided.

Many different types of fecllitles relesee radionuclldes into alr. These redlonuelldas differ in the chemicel and phyelcal form, half-lives and eype of rodiation enleted. The approprlate camination of

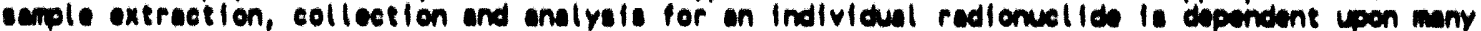
Interrelated fectors including the mixture of other redionvellose present. Beceuse of thls wide renge of

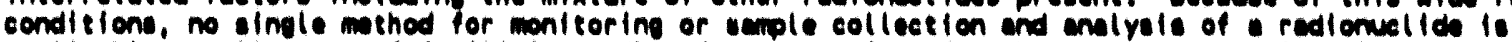

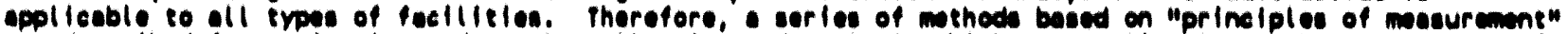

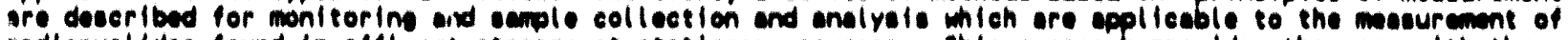

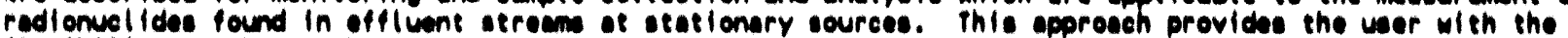

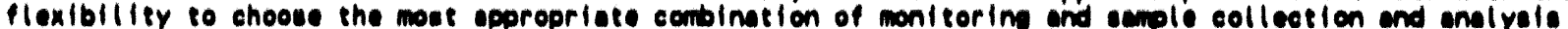
methods whleh ore applicable to the efflivent etreen to be moseured.

Response: Our answers to U.S. Environmental Protection Agency (EPA) requirements (regulatory criterla 40 CFR 61, Subpart H, Appendix B, Mothod 114) (EPA 1991) regarding Hanford site air emissions are provided nere.

\subsection{Eenak Monltering ind inmole Gollection Mnthods}

Monitering and senple collection metheds ore deseribed based on "principles of monltoring and eample

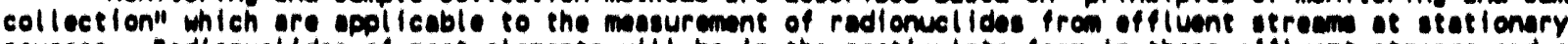
sources. Aedionuclides of most ol ements wlll be in the pertleulate form in these effluent serrecm and cen

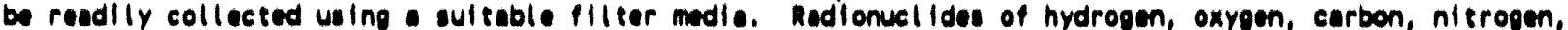
the noble geses and in som clrcumetances lodine will be in the gaseous form. Redlonvellades of these elements will require elther the use of on in-line or off-line monitor to directly maseure the radionuclldes, or sultable sorbers, condensers or bubblers to collect the redionuclldes.

\section{Response: No answer is required of radioanalytfcal chemistry.}

2.1 Redionuclides as partlculates. The extracted effluent stream lo passed through a fllter medle to remove the partleulates. The fliter must hove a high efflelency for removal of sub-micron particles. The guldance in AN8I N13.1-1969 oholl be foll lowed in using fllter madio to collect partlculates (Incorporated by reference-see 161.18 ).

See Appendices $A, B, C, D$, and $E$.

\subsection{Redlonuclldes as Gases.}

2.2.1 The Radionuclide irleliun (K-3). Frltilum In the form of water vapor lo collected from the extracted effluent semple by sorption, condensation or diseolution techniques. Appropriate collectors may include sllice sel, molecular leves, and ethylone olycol or water bubblers.

Tritlum in the gaseous form may be mesured directly in the semple etrean uning Method a.1, collected a. ase semple or may be oxidized using metal caselyet to prifloted woter and collected as deacribed above.

2.2.2 Redionucllides of lodine. lodine le collucted from an exirected semple by sorption or dissolution techniques. Approprlate collectors may include charcool, impregnated charcoul, metel zoollte and caustic solutions.

2.2.3 Radionuclides of Argon, Krypton and Xenon. Radionucll lose of these el cmants ore ol ther measured directly by an in-lime or off-l ine monitor, or ore colleced from the extrected semple by low temperature sorpetion techniques, Appropriate sorbers may include chercosl or matal zeollte.

2.2.4 Redionuclides of Oxyeen, Carbon. Mltrogen and Redon. Redionuclides of these el ements are measured directly using an in-line or off-line monitor. Redionuclides of carbon in the form of carbon dioxide may be collected by dissolution in caustic solutions.

See Appendices $A, D$, and $E$. 


\subsection{Definition of term}

In.llomemiter mans a continuous manurement ovatem in wich the detector le placed directly in or

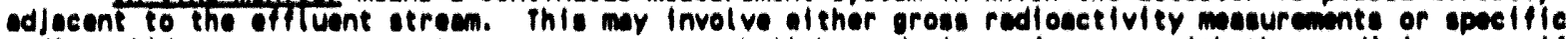
redionuclide mesurements. Grose mesurements shall be made in conformance with the conditions epecifled in Methods $A \cdot 4, B-2$, and 0.4 .

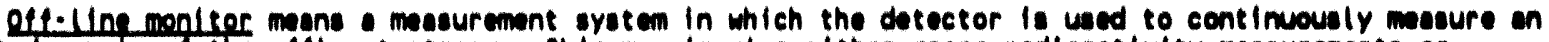
extrected semple of the effluent streen. Thle may involve el ther grose redioactivity mesurements or epecifle radionuclide measurements. Orose mesurements thell be made in conformance with the condlitions apectifled in Methode $A \cdot 4,8-2$ and 0.4 .

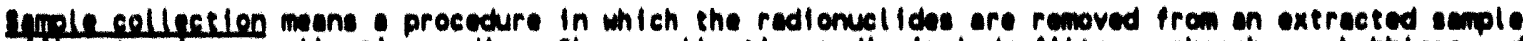
of the offluent using a collection media. these collection medle include fllters, absorbers, bubblere ond condensers. The collected semple to enalyeed using the mothode described in section 3.0.

\section{Response: No answer is requitred.}

\subsection{Indlonuallate anclyele meshodh}

A serles of methods besed on "princlples of measurement" ore described inleh are applleable to the analyols of radionuclides collected from ul rborne offluent streems ot etatlonary sources. These mathods are appl labble only under the conditions otated and within the IImitatione described. Sam mathods opeclfy that only . ingle redlomelide be present in the semple or the chemically separated ample. ihle condition should be interpreted to mean thet no other redionuclides ore present in quentitles which would interfere with the meseurement.

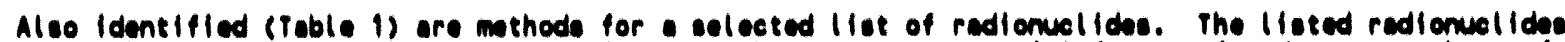
are those which ore most commonly used end which have the oreatest potentlol for causing dose to manbere of the public. Use of methode based on principles of meseurement other then those described in this asetion

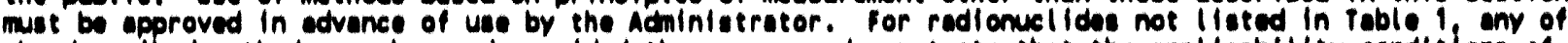
the described methods may be used provided the ueer can damonstrate that the applicability condlitions of the mathod have been mat.

The type of method applicable to the analyals of a redionuclide ls dependent upon the trpe of radiation emitted, l.e., elpha, bete or gemm. Therefore, the mathods described bellow ore grouped according

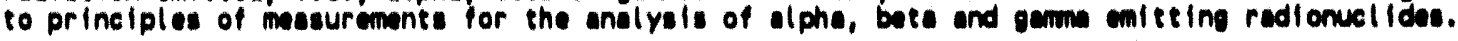

\subsection{Methods for Alphe Emiteing Radionuclides}

\subsubsection{Mothod A-1, Rad lochemistry-Alpha spectrometry.}

efinciole: the element of Interest ls separeted from other elcmente, and from the scmple matrix weing redfochenteal technlques. The procedure may involve precipisation, ion exchange, or solvent extrection. Carriere (elemente chemicelly eimiler to the element of interese) may be used. The el anent ls doposited on oplanchet in a very thin flim by electrodeposition or by coprecipltation on very emall mount of carrier, such as lenthanem fluorlde. The deposited ol ement is then counted wlth on alphe epectrometer. The ectivity of the nuclide of Interest lo maseured by the mumber of alphe counte in the appropriate energy region. A correction for chemical yield and counting effletency is made using. standardized redioactive nuclide (tracer) of the ame olement. If a radioactive tracer le not avellable for the olement of interest, - predetermined chemical yield factor may be used.

Apolicabllity: This method is applicable for dotermining the activity of any alphe-emiteino radionuctide, regardiess of what other radionuclides ore present in the cemple provided the chemical separation step produces a very thin sample and removes all other radionuclides which could interfere in the epectral region of interest. APHA-605(2), ASTH-0-3972(13).

Response: Our method involves dissolution (LA-549-112), chemical separation (LA-943-123), electrodeposition (LA-542-101), followed by alpha spectrometry (LA-508-051). It meets all the requirements of the EPA-suggested method. This is used for analyzing ${ }^{241} \mathrm{Am}$, ${ }^{238} \mathrm{Pu}$, and $239,240 \mathrm{Pu}$ in the air filter samples. The activities of these nuclides are determined by direct comparison with the recoveries of (National Institute of standards and Technology ([NIST] traceable) ${ }^{243} \mathrm{Am}$ and ${ }^{236} \mathrm{Pu}$ tracers.

\subsubsection{Method A-2, Radiochemistry-Alphe Counting.}

Peincioles The element of interest is separated from other elements, and from the semple matrix using radlochemistry. The procedure may involve precipitation, lon exchange, or solvent extraction. Carriers (elements chemically imilar to the olement of interest) may be weed. The element le doposited on 
a planchet in thin fllm and countad with alphe counter. A correction for chemical yiald (if neceesary) is made. The alphe count rate measures the total ectivity of all emitting redionuclides of the separeted element.

Applicabillty: This method is applicable for the measurement of any alpha-emitting radionuclide, provided no other atpha emitting radionuclide is present in the separated semple. It may also be applicable for determining compl iance, when other radionucl ides of the separated el ement are present, provided that the calculated emission rate 18 assigned to the radionuclide which could be present in the semple that has the highest dose conversion factor. 100-12096(18).

Response: Because the tracer technique is used in the separation process, this method is not used for air filter analysis.

\subsubsection{Method A-3, Direct Alpha Spectrometry.}

Principle: The sample, collected on a suitable filter, is counted directly on an alphe spactrometer. The sample must be thin enough and collected on the surface of the filter so that any absorption of alphe particle energy in the sample or the filter, which would degrade the spectrum, is minimal.

Applicability: This method is applicable to simple mixtures of alpha emitting radionuclides and only when the amount of particulates collected on the filter paper are relatively small and the alphe spectra is adequately resolved. Resolutions should be $50 \mathrm{keV}$ (FWHM) or better, ASTM-D-3084(16).

Response: Our method follows the procedure L0-150-133, then LA-508-110 for total alpha counts, and finally LA-508-051 for alpha spectrometry. It partially meets the requirements of the EPA mothod. This method is usually used for emergency air samples. The sample is counted on the alpha counter of known efficiency to obtain the total alpha counts. In the alpha energy analysis (AEA), the relative peak fractions of different alpha emitters identified in the sample are determined. The peak fractions are then used to correct the total alpha counts and thus cletermine the activities of individual alpha nuclides present in the s: s.ple. $^{n}$.

\subsubsection{Method A-4, Direct Alphe Counting (Gross alphe determination).}

principle: The sample, collected on a suitable filter, is counted with an alpha counter. The semple must be thin enough so that self-absorption is not significant and the filter must be of such o nature that the particles are retained on the surface.

Applicability: Gross alphe determination may be used to measure emissions of specific radionuclides only (1) when it is known that the sample contains only a single radionuclide, or the identity and isotopic ratio of the radionuclides in the sample are well known, and (2) measurements using ei ther Method A-1, A-2 or A-5 have shown that this method provides a reasonably accurate measurement of the emission rate. Gross alpha measurements are applicable to unidentified mixtures of radionuclides only for the purposes and under the conditions described in Section 3.7. APHA-601(3), ASTM-D-1943(10).

Response: The filter samples are counted in a low background thin-window gas-flow proportional counter with a guard detector operated in coincidence mode. It uses pulse height discriminator to separate alpha \& beta activity. Our method follows the procedure LA-508-11U or LA-508-114. It meets all of the requirements stated in the EPA-suggested method.

\subsubsection{Method A-5, Chemical Determination of Uranium.}

Uranium: Uranium may be measured chemically by either colorimetry or fluorometry. In both procedures, the sample is dissolved, the uranium is oxidized to the hexavalent form and extracted into a suitable solvent. Impurities are removed from the solvent layer. For colorimetry, dibenzoylmethane is added, and the uranium is measured by the absorbance in a colorimeter. For fluorometry, a portion of the solution is fused with a sodium fluoride-lithium fluoride flux and the uranium is determined by the ultraviolet activated fluorescence of the fused disk in a fluorometer.

Applicability: This method is applicable to the measuremants of emission rates of uranium when the isotopic ratio of the uranium radionuclides is well known. ASTM-E318(15), ASTM-D-2907(14). 
WHC-EP-0536-1

Response: Total uranium is determined by procedure LA-925-107. The laser-induced kinetic phosphorescence analyzer is an improvement over the old fluorometric method for uranium determination. It is highly sensitive (lower detection level of $50 \mathrm{ppt}$ is quite possible) because the laser frequency is used specifically for excitation of uranium atoms. It is faster and produces quality numbers. Quality can also be monitored during analysis. It exceeds the requirements mentioned in the EPA method.

\subsubsection{Method A-6, Radon-222-Continuous Gas Monitor.}

Princiole: Radon-222 is measured directly in a continuously extracted semple stream by paseing the air strean through a calibrated scintillation cell. Prior to the scintillation cell, the ir strean is treated to remove paiticulates and excess moisture. The alphe particles from radon-222 and its decay products strike a zinc sulfide coating on the inside of the scintillation cell producing light pulses. The light pulses are detected by a photomultiplier tube which generates electrical pulses. These pulses are processed by the system electronics and the read out is in $\mathrm{pC} / / 1$ of radon-222.

Apolicability: This method is applicable to the measurement of radon-222 in effluent streans which do not contain significant quantities of radon-220. Users of this method should calibrate the monitor in a radon calibration chamber at least twice per year. The beckground of the monitor should also be checked periodically by operating the instrument in a low radon environment. EPA 520/1-89-009(24).

\section{Response: Not applicable at the 222-S Laboratory.}

\subsubsection{Method A-7, Radon-222-Alphe Track Detectors}

Principle: Radon-222 is measured directly in the effluent stream using alphe track detectors (ATD). The alpha particles emitted by radon-222 and its decay products strike. small plastic strip and produce submicron damage tracks. The plastic strip is placed in a caustic solution that accentuates the damage tracks which are counted using a inicroscope or automatic counting system. The number of tracks per unit area is corrected to the radon concentration in air using a conversion factor derived from data generated in a radon calibration facility.

Applicability: Prior approval from EPA is required for use of this method. This method is only applicable to effluent streams thich do not contain significant quantities of radon-220, unless special detectors are used to discriminate against radon 220. This method may be used only when ATDs heve been demonstrated to produce data comparable to data obtained with Method A.6. Such data should be submitted to EPA when requesting approvel for the use of this method. EPA 520/1-89-009(24).

Response: Not applicable; direct monitoring of ${ }^{222} \mathrm{Rn}$ is not performed at the 222-S Laboratory.

3.2 Methods for Gaseous Beta Emitting Radionuclides.

3.2.1 Method B-1, Direct Counting in Flow-Through Ionization Chambers.

Principle: An ionization chamber containing a specific volume of gas which flows at given flow rate through the chamber is used. The sample (effluent stream sample) acts as the counting gas for the chamber. The activity of the radionuclide is determined from the current measured in the ionization chamber.

Applicability: This method is applicable for messuring the activity of aseous bete emitting radionuclide in en effluent stream that is suitable os a counting gas, when no other beta-emitting muclides are present. DOE/EP-0096(17), NCRP-58(23).

Response: Not applicable; not performed.

3.2.2 Method B-2, Direct Counting With In-line or Off-line Bete Detectors.

Principle: The beta detector is placed directly in the effluent siream (in-line) or all extracted sample of the effluent stream is passed through a chamber containing a beta detector (off-l ine:. The activities of the radionuclides present in the efflupent streos are determined from the beta counic rate, and a knowledge of the raci? onuclides present and the reiationship of the gross beta count ra ind the specific radionuclide concentration.

Applicability: This method is applicable only to radionuclides with maximum beta particle energies greater then $0.2 \mathrm{MeV}$. This method may be used to measure emissions of specific radionuclides only when it is known that the sample contains only a single radionuclide or the identity and isotopic ratio of the 
redionuclides in the effluent strean are well known. specific redionuclide analys is of periodic grab semples may be used to Identify the types and quantities of radionuclides present and to establish the relationship between specific redionuclide analyses and gross beta count rates.

This method is applicable to unidentified mixtures of gaseous radionuclides only for the purposes and under the conditions described in section 3.7.

Response: Not applicable; not performed.

3.3 Methods for Non-Gaseous Bete Emitting Radionuclides.

3.3.1 Method B-3, Radiochemistry-Bota Counting.

princiole: The element of interest is separated from other elcments, and from the semple matrix by radiochemistry. This may involve precipitation, distillation, ion exchenge, or solvent extraction. Carriers (elements chemically similar to the element of interest) may be used. The element is deposited on a planchet, and counted with a beta counter. Corrections for chemical yield and decay (if necessery) are made. The beta count rate determines the total activity of all radionuclides of the separated el ement. This method may also involve the radiochemical separation and counting of a daughter element, after a suitable period of ingrowth, in which case it is specific for the perent nuclide.

Apol lcability: This method is applicable for measuring the activity of any beta-emitting radionuclide, with maximum onergy greater than $0.2 \mathrm{MeV}$, provided no other radionuclide is present in the separated sample. APHA-608(5).

Response: Our method for determining ${ }^{89} \mathrm{Sr},{ }^{90} \mathrm{Sr} /{ }^{90} \mathrm{Y}$ in air filter samples is carried out using procedures LA-549-112 (dissolution of the filter sample by nitric acid) and LA-220-103 (for chemical separation), followed by procedure LA-508-111 (total beta counting). The laboratory method certainly meets the requirements stated above.

\subsubsection{Method B-4, Direct Beta Counting (Gross beta determination).}

Principle: The sample, collected on a suitable filter, is counted with beta counter. The sample must be thin enough so that self-absorption corrections can be made.

Apolicability: Gross beta measurements are applicable only to radionuclides with maximum beta particle energies greater thian $0.2 \mathrm{MeV}$. Gross beta measurements may be used to measure enissions of specific radionuclides only (1) when it is known that the sample contains only aingle radionuclide, and (2) measurements made using Method B-3 show reasonable agreement with the gross beta measurement. Gross beta measurements are applicable to mixtures of radionuclides only for the purposes and under the conditions described in Section 3.7. APHA-602(4), ASTM-D-1890(11).

Response: The filter samples are counted in a low background thin-window gas-flow proportional counter with a guard detector in coincidence mode. It uses pulse height discriminator to separate alpha \& beta activity. For gross beta determination, procedure LF-508-110 or LA-508-114 is followed. It satisfies the method requirements.

\subsubsection{Methad 8.5, Liquid Scintillation Spectrometry.}

Principle: An allquot of a collected sample or the result of some other chemical separation or processing technique is added to a liquid scintillation "cocktail" which is viewed by photomultiplier tubes in a liquid scintillation spectrometer. The spectrometer is adjusted to establish a channel or "window" for the pulse energy appropriate to the nuclide of interest. The activity of the nuclide of interest is measured by the counting rate in the appropriate energy channel. Corrections are made for chemical yield where separations are made.

Apolicability: This method is applicable to any beta-emitting nuclide then no other radionuclide is present in the sample or the separated sample provided that it can be incorporated in the scintillation cockteil. This methxd is also applicable for samples which contain more than one radionuclide but only when the energies of the beta particles are sufficiently separated so that they can be resolved by the specirameter. This method is most applicable to the measurement of low-energy beta emitters such as tritium and carbon-14. APHA.609(6), EML LV-539-17(19).

Response: It is used for determining ${ }^{147} \mathrm{Pm}$ in air filter samples (LA-549-112 for dissolution of the filter by nitric acid, LA-613-111 for chem cal separation to isolate the desired beta nuclide, LA-548-111 for 
incorporating into scintillation cocktail, and LA-508-121 for liquid scintillation counting). This is also used for determination of ${ }^{14} \mathrm{C}$ (LA-348-101, LA-548-111, and LA-508-121, sequent1ally) and ${ }^{3} \mathrm{H}$ (LA-218-112, LA-548-111, and LA-508-121, sequentiallJ) in gas samples. This method satisfies all of the requirements.

\subsection{Gamm Emitting Radionuclides}

3.4.1 Method 6-1. High Resolution Gamm Spectrometry.

Principle: The sample is counted with a high resolution gamm dotector, usually elther Ge(Li) or high purity be detector, connected to a multichannel analyzer or computer. The ganma enltting radionuclidas in the semple ore measured from the gamme count rates in the energy regions characteristic of the individual radionuclide. Corrections are made for counts contributed by other radionuclides to the spectral regions of the radionuclides of interest. Radiochemical separations may be made prior to counting but are usually not necessary.

Apolicabllity: This method is applicable to the measurement of any gamme emitting radionuclide with gamma energies greater than $20 \mathrm{keV}$. It can be applied to complex mixtures of radionuclides. The semples counted may be in the form of particulate filters, absorbers, liguids or gases. The method may also be applied to the analys is of gaseous garma emitting radionuclides directly in an effluent strean by passing the stream through a chamber or cell containing the detector. AsTM-3649(9), 100-12096(18).

Response: The dally \& weekly air filters are quarterly composited and then directly counted on a high resolution Ge detector. The silver zeolite cartridges are counted on a n-type high purity Ge detector (very useful for low gamma \& $x$-rays). The procedure used for analysis with gamma-ray spectroscopy is LA-508-052. Our method uses gamma ray spectroscopy with high resolution germanium detectors and follows procedure $L A-508-052$. It meets all the requirements explained in the EPA method.

\subsubsection{Method G-2, Low Resolution Gamma Spectrometry.}

Principle: The sample is counted with a low resolution gamm detector, a thallium activated sodium iodide crystal. The detector is coupled to o photomultiplier tube and connected to a multicharmel analyzer. The gamma enitting radionuclides in the sample are measured from the gamme count rates in the energy regions characteristic of the individual radionuclides. Corrections are made for counts contributed by other radionuclides to the spectral regions of the radionuclides of interest. Radiochemical separation may be used prior to counting to obtain less complex gamma spectra if needed.

Apolicability: This method is applicable to the measurement of gams emitting radionuclides with energies greater than $100 \mathrm{keV}$. It can be applied only to relatively simple mixtures of gemm emitting radionuclides. The samples counted may be in the form of particulate filters, absorbers, liquids or gas. The method can be applled to the analysis of gaseous radionuclides directly in an effluent stream by passing the gas stream through a chamber or cell containing the detector. ASTM-D-2459(12), EMSL-LV-0539-17(19).

Response: Not applicable because this method is not used in air filter analysis.

\subsubsection{Method G-3, Single Channel Gamb spectrometry.}

Principle: The sample is counted with a thallium activated sodium lodide crystal. The detector is coupled to photomultiplier tube connected to a single chamel analyzer. The activity of aemm emitting radionuclide is determined from the gamme counts in the energy range for which the counter is set.

Applicability: This method is applicable to the measurement of a single ganme emitting radionuclide. It is not applicable to mixtures of radionuclides. The samples counted may be in the form of particulate filters, absorbers, liquids or gas. The method can be applied to the analysis af gaseous radionuclides directly in an effluent stream by passing the gas stream through a chamber or cell containing the detector.

Response: Not applicable because this tectinique is not used in air filter analysis. 


\subsubsection{Method 0.4, Gross Game Counting.}

Principle: The sample is counted with o gamm detector usually a thallium activated sodium lodine crystal. The detector is coupled to a photomultipller tube and gamm rays above apecifle threshold energy lovel are counted.

Apolicability: Gross garma measurements may be used to measure emissions of speciflc radionucllodes only when it 18 known that the sample contains a single radionuclide or the Identity and lsotopic ratio of the radionuclides in the effluent stream are well known. When grose gemm measurements are used to determine emissions of specifle radionuclides perlodic measurements using methods 6.1 or 0.2 should be mede to demonstrate that the gross ganm measurements provide rellable emission data. This method may be applied to analysis of gaseous radionuclldes directly in an offluent streem by placing the detector directly in or adjacent to the effluent stream or passing an exeracted semple of the effluent strean through chember or cell conteining the detector.

\section{Response: Not applicable.}

3.5 Counting Methods. All of the methods with the exception of Method A.5 involve counting the radiation emitted by the radionuclide. Counting methods applicable to the measurement of olpha, beta and gamma radiations are listed below. The oquipment needed and the counting principles involved are described in detail in ASTM-3648(8).

\subsubsection{Alpha Counting:}

Gas floy proportional counters. The alphe particles cause lonization in tha counting gas and the resulting electrical pulses are counted. These counters may be windowlese or have very thin windows.

uscint 14 lation counters. The alpha particles transfer energy to a scintillator resulting in a production of tight photons which strike o photomultipl ier tube converting the llght photons to electrical pulses which are counted. The counters may involve the use of solid scintillation materials such as zinc sulfide or liquid scintillation solutions.

-Solid-state counters. Semiconductor materials, such as silicon surface-barrier p-n junctions, act as solid ionization chambers. The alpha particles interact which the detector producing electron hole pairs. The charged pair is collected by an applied electrical field and the resulting electrical pulses are counted.

-Alpho spectrometers. Semiconductor detectors used in conjunction with multichannel analyzers for energy discrimination.

Response: Alpha proportional counters (home-built chambers with EG\&G ORTEC electronics), thin-window-type gas flow proportional counters (some having automatic sample changer), surface-barrier solid-state detectors connected to a multichannel analyzer (MCA) (Series 85, Jupiter system manufactured by Canberra Industries, Inc.) are used for air filter analysis in 222-S laboratory. Laboratory equipment meets the EPA specifications.

\subsubsection{Beta Counting:}

- Ionization Chambers. These chambers contain the beta-emitting nuclide in gaseous form. The ionization current produced is measured.

-Geiger-Muller (GM) Counters-or Gas floy Proportional Counters. The bete particles cause lonization in the counting gas and the resulting electrical pulses are counted. proportional ges flow counters which ore heavily shielded by lead or other matal, and provided with an anti-coincidence shield to reject cosmic rays, are called low beckground beta counters.

- Scintillation counters. The beta particles transfer energy to a scintillator resulting in production of light photons, which strike photomultiplier tube converting the light photon to electrical pulses which ore counted. This may involve the use of anthrace - crystals, plastic scintillator, or liquid scintillation solutions with organic phosphors.

- Liquid Scintillation Spectrometers. Liquid scintillation counters which use two photomultiplier tubes in coincidence to reduce background counts. This counter may also lectronically discrilinate among pulses of a given range of energy. 
Response: Thin-Window-type gas flow proportional counter (some having an automatic sample changer) liquid scintillation spectrometers manufactured by Beckman Instruments, Inc., are used for analysis. Our counting equipment meets the requirements.

\subsubsection{Gemm Counting:}

ahoy-8esolution oamm spactromatere. The garma raye interact with thalllum activated sodiun lodide or ceslum lodide cryetel resulting in the relesse of light photons which trike. photomultiplier tube converting the llght pulses to electrical pulses proportional to the energy of the germe rey. Multi-chermel analyzers are used to separate and store the pulses according to the eneroy absorbed in the cryetol.

Whioh-Resolution gamm Soectrometers. Gemma rays interact with a lithium-drifted (Ge(Li)) or high-purity germanium (HPGe) semiconductor detectors resulting in production of electron-hole pairs. The charged pair is collectod by an applied electrical field. A very stable low nol se preamplifier amplifies the pulses of electrical charge resulting from the garma photon interactions. Multichannel analyzers or computers are used to separate and store the pulses according to the energy absorbed in the crystal.

esingle channel Analyzers. Thallium activated sodium lodide crystals used with a single window analyzer. Pulses from the photomultiplier tubes are separated in a single predetermined energy range.

Response: High-resolution gamma detectors (closed-end HPGe coaxial) and wel1-type pure Ge detectors (from ORTEC and Princeton Gamma Tech) connected to MCA (Canberra's Juplter system) are avallable and used for air filter analysis. Our equipment exceeds the EPA requirements.

3.5.4 Calibration of Counters. Counters are calibrated for specifle radionuclide measurements using a standard of the radionuclide under elther identical or very similar conditions as the semple to be counted. For gamma spectrometers a series of stanoerds covering the energy range of interest may be used to construct a calibration curve relating gamma energy to counting efficiency.

In those cases where a standard is not available for a radionuclide, counters may be calibrated using a standard with energy characteristics as similar as possible to the radionuclide to be measured. For gross alpha and beta measurements of the unidentlfled mixtures of radionuclides, alpha counters are callbrated with a natural uranium standard and bete counters with a cesium-137 standard. The standerd must contain the seme waight and distribution of sollds as the samples, and be mounted in an identical marner. If the sample; contain variable amounts of solids, calibration curves relating weight of sollds present to counting efficiency ore prepared. Standards other than those prescribed may be used provided it can be shown that such standerds are more applicable to the radionuclide mixture masured.

Response: A mixed gamma standard (NIST traceable) emitting varlous gamma-rays ranging from 59 to $1850 \mathrm{keV}$ is used, using vendor-supplied calibration software, for constructing efficiency versus energy calibration curves for different geometrical configurations used in gamma analysis. The calibration procedure for gamma ray spectrometer is documented in LQ-508-003. Our calibration procedure meets the EPA criteria for gamma ray spectroscopic analysis.

For calibration of beta detectors for ${ }^{90} \mathrm{Sr} /{ }^{90} \mathrm{y}$ analysis, procedure LQ-508-002 is used in conjunction with LQ-508-005. It meets the requirements of the EPA-suggested method. A method standard also is used to check the performance a.d calibration of the detector.

For calibration of alpha/beta proportional counters, the procedure LQ-508-002 is carried out. It partially deviates from the EPA requirements. For gross alpha and gross beta measurements, our instruments are calibrated with NIST traceable alpha emitting ${ }^{241} \mathrm{Am}$ and beta emitting ${ }^{60} \mathrm{Co}$ standards respectively, fabricated into the filter sample counting geometry. The reasons for choosing the ${ }^{241} \mathrm{Am}$ standard for alpha calibration are as follows:

- It is commonly found in the main stack air samples. 
- Alpha counting efficiency usually is the same for other alpha emitters that also are found in the air stack samples

- The ${ }^{249}$ Am standard also can be checked independently by gamma analysis.

The reason for using the ${ }^{60} \mathrm{Co}$ standard for beta callbration is the lower counting efflclency with ${ }^{60} \mathrm{Co}$ (beta max $-317 \mathrm{keV}$ ) compared to those with ${ }^{13} \mathrm{Cs}$ (beta $\max =511 \mathrm{keV}$ ) and ${ }^{90} \mathrm{Sr}$ (beta $\max =546 \mathrm{keV}$ ). Consequently, it will generate conservative numbers in our analysis.

The calibration curves relating weight of solids present to counting efficiencies are not done in aipha/beta analysis, but currently are being evaluated.

3.6 Radiochemical Methode for Selected Redionuclides. Methode for selected list of redionuclides ore listed in Table 1. The redionuclides listed are those which are most commonly used and which hove the oreatest potential for causing doses to membars of the publlc. For radionuclides not listed in Table 1. methods based on any of the applicable "principles of measurement" described in section 3.1 through 3.4 " may be used.

Response: The air samples from the majn stacks are well characterjzed.

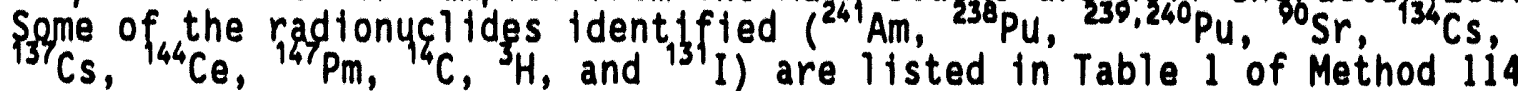
(EPA 1991) and are analyzed according to the approved methods given in the table. Other radionuclides $\left({ }^{85} \mathrm{Nb},{ }^{95} \mathrm{Zr},{ }^{129} \mathrm{I},{ }^{106} \mathrm{Rh} /{ }^{106} \mathrm{Ru},{ }^{119} \mathrm{Sn},{ }^{125} \mathrm{Sb}\right.$, and ${ }^{103} \mathrm{Ru}$ ) not listed in the table are analyzed by the methods out 7 ined in Method 114, depending on the type of emitted radiations. It is important to note here that the nuclides ${ }^{95} \mathrm{Zr},{ }^{95} \mathrm{Nb}$, and ${ }^{103} \mathrm{Ru}$ have nearly decayed to nondetectable levels because no product is being produced.

3.7 Applicabillty of Gross Alphe and Beta Measurements to Unidentified Mixtures of Radionuclides. Gross alphe and beta measurements may be used as a screening messurement as a part of an emission measurement progran to identify the need to do specific radionuclide analyses or to confirm or verlfy that unexpected radionuclides are not being released in sionificant quantities.

Gross alphe (Method A-4) or gross bete (Methods B-2 or B-4) messurements may also be used for the purpose of comparing the measured concentrations in the effluent treen with the IImiting "Concentration Levels for Environmental Compllance" in Table 2 of Appendix E. For unidentifled mixtures, the measured concentration value shall be compered with the lowest envirormental concentration limit for any redionuclide which is not known to be absent from the effluent stream.

Response: This is not applicable because the air effluents from the Hanford Site main stacks are well characterized. However, gross alpha and beta analyses for weekly and daily air samples are routinely performed in the 222-S Laboratory before starting specific radionuclide analyses. Followir.g this practice, the facility can verify a significant release of a radionuclide into the air so corrective actions to minimize radionuclide emission into the environment can be taken promptly by facility personne?. The gross alpha and beta results from analysis are compared to those listed in the appendix of DOE Order 5400.5 (DOE 1990) for compliance.

\subsection{Quality Assurance Methods}

Each facility required to measure their radionuclide emissions shall conduct a quality assurance program in conjunction with the radionuclide emission measurements. This program shall assure that the emission measurements are representative, and are of known precision and accuracy and shall include administrative controls to assure prompt response when emission measurements indicate unexpectedly large emissions. The program shall consist of system of policies, organizational responsibilities, written 
procedures, date quallty speciflcations, audits, corrective ections and reports. This quallty asaurance progrum shall include the following progren elements:

4.1 The organizational structure functional responsibllities, levels of authorlty and lines of communications for all activities related to the emlestons masurement progrem shall be ldentified and documented.

The company manual WHC-CM-1-2, Organizational Charts and Charters, exhibits the current company organizational structure and titles. This manual includes the organization's upper level management charters. Responsibilities for radloactive airborne emissions sampling activities are described in the main pat of this document.

4.2 Administrative controls shall be prescribed to ensure prompt respones in the event thet emiselon levels increase due to unplanned operations.

See Appendices $A, B, C, D$, and E.

4.3 The semple collection and analysis procedures used in meseuring the emiselais ahall be deseribed including where appl lcable:

4.3.1 Identification of sempling sites and number of sampling pointe, including the rationale for site selections.

See Appendices $A, B, C, D$, and E.

4.3.2 A deseription of sampling probes and representetiveness of the samples.

See Appendices $A, B, C, D$, and $E$.

4.3.3 A description of any continuous monitoring system used to mensure emiseions, including the sensitivity of the system, calibration procedures and frequency of callibration.

See Appendices $A, B, C, D$, and $E$.

4.3.4 A description of the semple collection systeme for eech redionuclide measured, including frequency of collection, callibration procedures and frequency of calibration.

See Appendices $A, B, C, D$, and $E$.

4.3.5 A description of the laboratory analysis procedures used for each radionuclide measured. including frequency of analys is callibretion procedures and frequency of callibration.

Response:

- Total alpha/total beta activity is determined by procedure LA-508-110 or LA-508-114 on weekly samples, and occasionally on daily air samples, per collection point. The calibration procedure is documented in $\mathrm{LQ}-508-002$. It is done only when deemed necessary by a responsible scientist. The counting system is recalibrated only in case of (1) major repairs or adjustments to the power supply or detector or (2) calibration shift as indicated by the instrument control standards. The performance of the counting systems is checked by running the instrument contro] standards $\left({ }^{147} \mathrm{Pm}\right.$ for $10 \mathrm{w}-$ energy beta, ${ }^{60} \mathrm{Co}$ for mid-energy beta, ${ }^{137} \mathrm{Cs}$ for high-energy beta, and ${ }^{241} \mathrm{Am}$ for alpha activity) separately. When a batch of air filter samples is run, all the performance standards and the background (for counting frequency refer to L0-150-115) also are run with it. To verify that the counting system is working properly, the standard values from analysis should fall within the 
administrative limits set according to appropriate quality assurance program plans (QAPP).

- Our labpratory method for analysis of alpha emitters $\left({ }^{241} \mathrm{Am},{ }^{238} \mathrm{Pu}\right.$, and $239,240 \mathrm{Pu}$ ) involves varlous steps (LA-549-112 for dissolution, LA-943-123 for chemical separation, LA-542-101 for electrodeposition, and LA-508-05I for final alpha spectrometry). The analysis of alpha emitters is done quarterly on weekly/daily air fliter samples. The energy resolution and callibration of the AEA system over the energy range of 4 to $6 \mathrm{MeV}$ are checked once a month by the preventive maintenance (PM) procedure 2S18006. Efficiency cal fbration of the AEA is not needed in our analysis method because direct comparison of the sample with recoverles of the tracers ( ${ }^{243} \mathrm{Am}$ and ${ }^{236} \mathrm{Pu}$ ) is made to determine the activities of the radionuclides present in the sample. To carry out the sample analysis, AEA system performance is checked once every 24 hours for alpha energy shift with a certifled mixed alpha source standard. Each alpha energy peak identified in the standard must fall with in administratively assigned certain channels $( \pm 10)$ on the MCA. For counting frequency of performance check standards, procedure L0-150-115 is referred to. The recovery of the radionuclides and the calibration of the system are checked on a batch basis by running a method standard under the identical conditions as the sample.

- The 1 ab method for determining beta activity $\left({ }^{89} \mathrm{Sr},{ }^{90} \mathrm{Sr} /{ }^{90} \mathrm{y}\right)$ consists of a dissolution step (LA-549-112), chemical separation (LA-220-103), and total beta counting (LA-508-111). Analys is is done quarterly on weekly/daily air filter samples per collaction point. The calibration procedure LQ-508-002 (for winduw-type gas flow proportional counter) is used in conjunction with LQ-508-005 (for mother/daughter case, 1.e., ${ }^{90} \mathrm{sr} /{ }^{90} \mathrm{y}$ in growth callbration). It is performed only when the responsible scientist finds it necessary. The reasons are the same as stated for total alpha/total beta. The performance of the counting system is checked once per shift by running instrument control standards $\left({ }^{60} \mathrm{Co},{ }_{90} \mathrm{Cs}\right.$, and ${ }^{147} \mathrm{Pm}$ for beta activity). The complete procedure for the ${ }^{90} \mathrm{Sr} /{ }^{90} \mathrm{Y}$ analysis in the sample is carried out with a method standard (several filter papers spiked with ${ }^{90} \mathrm{Sr},{ }^{147} \mathrm{Pm},{ }^{60} \mathrm{Co},{ }^{241} \mathrm{Am},{ }^{230} \mathrm{Pu}$, and $\left.U\right)$ provided by the 222-SA Standard Laboratory) on a batch basis. This checks the overall performance of our method. The chemical yield is determined by using appropriate carrier.

- Determination of beta activity $\left({ }^{147} \mathrm{Pm},{ }^{14} \mathrm{C}\right.$, and ${ }^{3} \mathrm{H}$ ) involves
processing (LA-549-112 and $L A-613-111$ for ${ }^{147} \mathrm{Pm}, L A-348-101$ for ${ }^{14} \mathrm{C}$, and $\left(A-218-112\right.$ for $\left.{ }^{3} H\right)$, mounting in scintillation cocktail (LA-508-111), and finally, liquid scintillation counting (LA-508-121). The ${ }^{147} \mathrm{Pm}$ analysis is done on quarterly composites of weekly/daily air filter samples. The ${ }^{14} \mathrm{C}$ and ${ }^{3} \mathrm{H}$ analyses are done on biweekly gas samples. For calibration, the quality assurance (QA) section of procedure LA-508-121 is referenced. The calibration of the instrument is checked by the manufacturer's supplied sources $\left({ }^{14} \mathrm{C}\right.$ and $\left.{ }^{3} \mathrm{H}\right)$ and its software. 
For ${ }^{147} \mathrm{Pm}$ analysis, the method standard is run once per quarter The method standard is always run with a batch of samplas for ${ }^{3} \mathrm{H}$ and ${ }^{14} \mathrm{C}$ analysis. The results of the method standard checks the overall performance, including the calibration of the counting system. The instrument calfbration check is done a minimum of once a week (refer to $(0-150-115)$.

- For analysis of gamma emitters ${ }^{95} \mathrm{Nb},{ }^{95} \mathrm{Zr},{ }^{134} \mathrm{Cs},{ }^{137} \mathrm{Cs}$, and ${ }^{144} \mathrm{Ce}$ the procedure LA-508-052 is followed. Analysis is done on quarterly

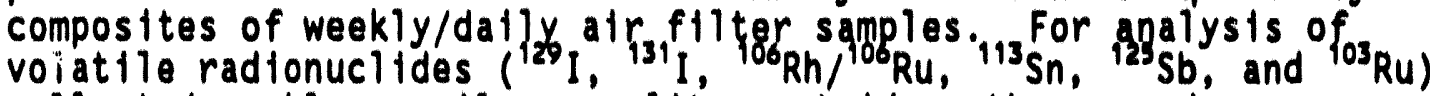
collected weekly on silver zeolite cartridge, the procedure LA-288-101 is used in conjunction with procedure LA-508-052. Calibration of the gamma ray spectrometer is done with the procedure documented in LQ-508-003 using a (NIST traceable) certified mixed gamma ray standard. It is carried out only when it is deemed necessary by a responsible scientist. To check efficlency and energy calibration dally, the performance of each detector of the GEA system over the whole energy range is done once every shift by running a mixed gamma standard consisting of ${ }^{241} \mathrm{Am}$ for low energy, ${ }^{137} C_{s}$ for mid energy, and ${ }^{60} C_{0}$ for high energy. The results of each of these radionucildes should fall within the administrative 1 imits set according to the appropriate QAPP to continue analysis of samples. The dally performance results are documented. Minor adjustments of the electronics (1.e., fine gain, pole zero of the ampliffers, lower level discriminator of analog-to-digital converter, etc.) are done from time to time when necessary for proper energy calibration. Whenever a minor electronic adjustment is done on a detector, it is followed by analysis of a performance standard. For a major shift in the calibration, the system is then thoroughly callbrated using LQ-508-003.

- The content of the 222-S Laboratory's procedures, test plans, supporting documents, and drawings provide a sufficlent level of detall to allow trained personnel to produce quality results safely. Laboratory procedures are controlled as required by WHC $-\mathrm{CM}-5-4$, Section 5.4, "Analytical Laboratory Procedures." The specific content of laboratory procedures is defined by its author, based on accepted methods such as 40 CFR 61, Appendix B, Method 114 (EPA 1991). The content must be agreed to by the peer and technical reviewers. While authors are responsible for the specific content of their procedures, they address the topics below.

SUmmary - MANDNTORY - A short description or abstract of the procedure containing enough information to distinguish it from other procedures.

Apolications - MANDATORY - Defines the scope and purpose of the specific procedure. This section may be combined with the following element under the title "Applications and Limitations."

Limitations - MANDATORY - Briefly describes those areas in which the procedure is not applicable. A statement of accuracy and precision will be given where appropriate. 
Quality control Protocol - Procedures used to support environmental projects that have specific quality control requirements. For these procedures, the source of the quality control requirements will be identifled. The samples or project that this element applies to will be identified. The following information is typical of quality control requirements: frequency and type of callbration, reagent blank analysis, spike sample analysis, and duplicate sample analysis.

Impact Level Identiffer - MANDATORY - An Impact level w111 be identified for each procedure following WHC-CM-1-3, MRP 5.43, with a brief basis of determination statement. This MRP ilsts several descriptive paragraphs delineating what constitutes an Impact Leve1 1, 2, 3, or 4 activity. The following parts of MRP 5.43 cover most analytical laboratory procedures.

1. Section 5, paragraph 6, part c., Impact Leve1 3 - work authorization documentation assoctated with work involving occupational hazards not covered by approved procedure, such as Operational Safoty Assessments, Radiation Work Permits, or Industrial Safety Standards.

2. Section 5, paragraph 6, part c., Impact Level 4-Documentation for any activity not classed as Impact Level 1, 2, or 3.

The laboratories' procedures are usually specific to one activity. These activities are well defined using common scientific instrumentation and equipment operated in an acceptable manner. The chamicals and materials used are normally small quantities with 1 imitad potential for environmental or personnel safety impact. In general, the equipment used in the laboratory is not classified as Safety Class 3 or higher.

Safety - MANDATORY - The procedure must identify applicable safety hazards.

The following documents identify Westinghouse Hanford Company (Westinghouse Hanford) safety requirements:

- WHC-CM-4-3, Volume 1-3, Industrial Safety

- WHC-CM-4-10, Radiation Protection

- WHC-CM-4-15, Badiation Work ReQuirements and Work Permits Manual

- WHC-CM-4-29, Nuclear Criticality Safety.

Supporting document WHC-SD-CP-LB-003, Safety in the Analytical Laboratory, is the laboratory general safety document. The authors must review safety requirements and include safety warnings appropriate to the actions directed by the procedure. 
Beagents - If the procedure requires analytical reagents, a 11st of reagents will be provided. The MSDS number wtll be placed in brackets by each chemical name. Reagent makeup, storage container requirements, unique storage needs, shelf-11fe requirements, spectal laboling, and spectal preparation steps will be included. Spectal notations for any known or suspected carcinogen as listed on WHC-CM-4-3, Volume 2, Table 1, "WHC Master Carcinogen List," will be made on the reagent ifst.

Reagent preparation described fully in other current Westinghouse Hanford documentation may be included by reference.

Equipment - Spectal equipment needs w111 be 11sted. Standard hood or glovebox equipment is assumed to be avallable at the work station and does not need to be listed. The fabrication of off-standard equipment will be referenced or described in this section.

Procedure Steps - MANDATORY - A step-by-step description of operations necessary to perform the task will be presented in a logical and sequentially numbered order or an assignment of responsibllitles. CAUTIONS and WARNINGS notations will be included for the applicable safety hazard before the action is described. Steps with potential for criticaltty specification violation will be identifled. Explanatory "Notes" may be included for ciarffication of process.

Calculations - Calculations required to complete the work w111 be described in this section. Examples with sample values may be included. All combined factors will be fully described and units noted.

Calibrations - When calibrations are required, a description of how to carry out required callibrations will be given.

Discussion - A discussion of the theoretical aspects of the procedure. Brief identification of unlque characteristics and interfaces to aid in troubleshooting may be included.

References - A reference list of published information to provide technical basis for the procedure may be included.

The mandatory topics are addressed in both procedures. However, the laboratories have technical, analytical, and administrative procedures. Non-mandatory topics are included if approprlate to the activity covered by the procedure.

The calibrations of all laboratory instruments are controlled by the Laboratory Instrument Calibration Control System (LICCS)

(WHC-CM-5-4, Section 8.2). The LICCS documents the requirements for and the performance of calibration activities for each analytical instrument or measurement device. 


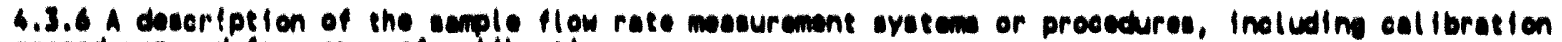
procedures and frequeney of coll bration.

See Appendices $A, B, C, D$, and $E$.

4.3.7 A deserfotion of the effluent flow rate masurement procectures, ineluding frequency of meseduremente, calibrotion procedures and frequency of collibration.

See Appendices $A, B, C, D$, and $E$.

6.6 the objectlves of the quallty assurance progrem sholl be doeumented and ohall otate the requlred

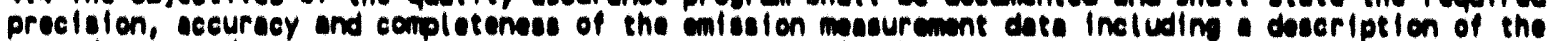

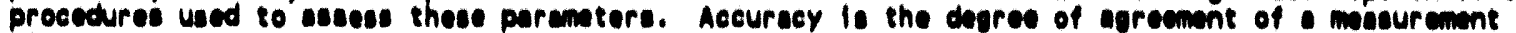

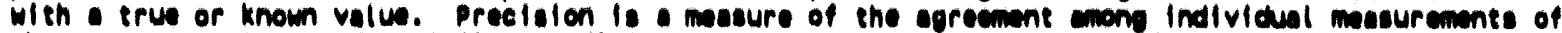
the seme parameters under simllar conditions. Completenses is a masure of the curount of data obteined compered to the conount expected under normal conditions.

The accuracy of analyses is checked using percent recovery. The evaluation of blind or known check standards provides the percent recovery.

For both blind and known check standards, percent recovery is calculated by the following equation:

$$
P=100 \cdot \frac{R}{S_{t}}
$$

Where:

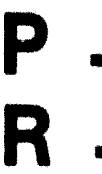

Percent recovery

Measured or recovered analyte concentration in the check standard

$S_{t}$

Concentration of analyte in the check standard.

The laboratories do not use manual W. A. Shewhart control charts (Shewhart 1931). The Laboratory Measurement Control System (LMCS) is a software package designed for support of management quality control decisions. Each analytical measurement system has different control parameter requirements based on the use of spectflc standards. The LMCS program provide a performance versus limits control chart for each standard. The average percent recovery $(\vec{P})$ or $100 \%$, depending on the method, marks the center of the 1 imit. The upper and lower boundarles of the limits are multiples of the standard deviation (s) of the average percent recivery. The laboratory manager approves the LMCS limits, defined as $P \pm n s$, where $n$ is a positive number. The values for $P$ and $s$ are either performance based. In general, management sets the warning limits at $2 \mathrm{~s}$ and the control limits at $3 \mathrm{~s}$ or their equivalent.

When the LMCS identifies an out-of-control method, it aut,omatically initlates corrective action. The system issues an off standard Condition Report (OSCR). The sclentist in charge of the method must discover and resolve the problem to close out the OSCR. Until the OSCR has been 
clear, personnel can not perform any analyses by this mothod. After the sclentlst has resolved the problem, personnel evaluate $a 11$ analyses performed since the last in-control point.

The laboratories assess precision by examining the results from split samples or laboratory duplicates. Percent relative difference measures the precision of analyses. Percent relative difference is computed by the following equation:

$$
R D=100 \cdot \frac{S_{d}}{\bar{X}}
$$

Where:

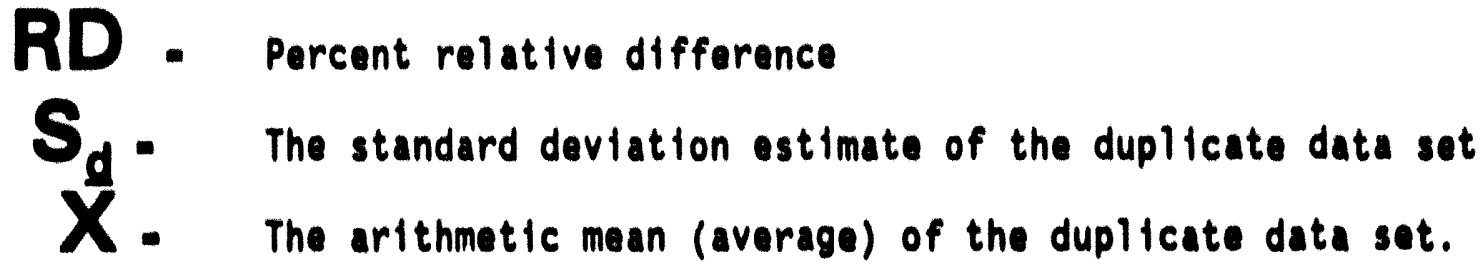

The initial QA objective for completeness of analyses in the laboratories is $90 \%$. This means that the goal is to produce usable analytical data for a minimum of $90 \%$ of the analyses requested on all samples submitted to the laboratory. The laboratory evaluates actual performance against the $90 \%$ objective. If the laboratory performance drops below this 1 imit, management inftiates corrective action. This action shall identify and correct those activities within the laboratory that have caused the drop in performance.

4.5 A qualley control progrem thall be eatabllahed to ovaluate and traek the quallty of the calselone masourcment data agoinst preset erfterle. The progrem onould Include there applleable o avatem of replleates, eplked semples, split semples, blenke and control charts. The number and prequeney of uch quality eontrol thecke thall be identifled.

The samples analyzed under this program consist of mounts made from preparation of stack filters. Each sample collection point produces only one sample which is sent to the laboratory for analysis. No replicate samples are avallable. Repeat measurement of individual samples are made at the discretion of the scientist in charge.

As a type of process control samples, stack fliters are not subject to

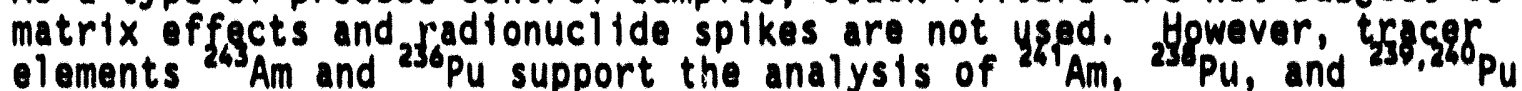
in the quarterly composite of weekly filter samples.

The laboratory does not split samples. There is no guarantee that the distribution of material on the filter will be homogenous. Because of this, no subsampling procedure, such as splitting, can be assured of producing two representative portions. Also, splitting the sample in effect dilutes the sample, which would adversely effects the method detection limits. 


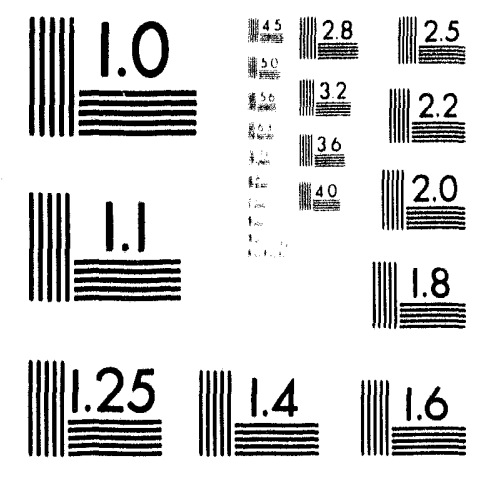



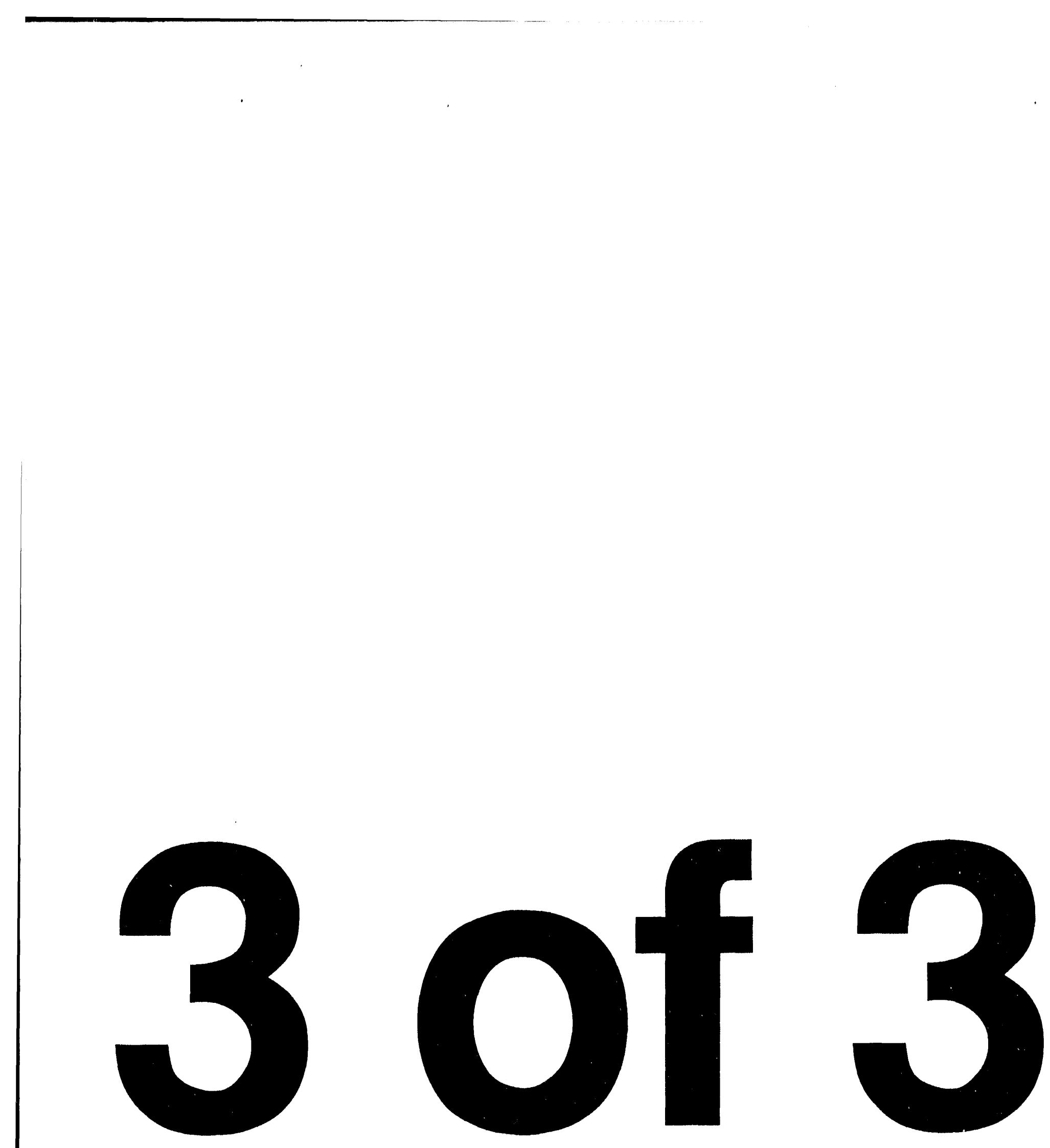
WHC-EP-0536-1

Formal blanks are not avallable for these analysis. However, prior to the analysis of a batch of samples, the background of the counting instrument is checked. This background check as made on each planchet and planchet holder.

Control charts and standards used in support of these analys is are described in Section 4.4 .

4.6 A sample tracking system shall be established to provide for positive identification of samples and date through all phases of the semple collection, analysis and reporting system. Semple handling and preservation procedures sholl be established to maintain the integrity of samples during collection, storage and analysis.

These samples come from fixed sample points and are analyzed according to established sample schedules. When requesting an analysis, the customer accesses the laboratory's sample and information management system which connects to the database, where the customer enters the request for analysis following LC-608-001, "LCCS User." The system generates the next available sample identification number and transmits it to the customer. The customer's activities, except for use of the laboratory's sample and information systems, are not covered by' the laboratory's QAPP.

Sample traceability begins with the database issuance of a unique sample identification number to the requesting customer. With this number the database references the date and time of the request, the customer's identification, the sample point, and type of analysis. Other information required to maintain the traceability of samples, such as date and time of sampling, is controlled by the customer and is not covered by this QAPP.

For each requested analysis, the database generates an analytical card. The card lists the sample, customer, and analysis requested. When the sample arrives at the laboratory, it is matched to its analytical card. The sample is then carried through the analysis listed on the card. Due to the turnaround time required on these samples, they are not normally stored. If it should become necessary, the 222-S Laboratory has secure laboratory storage available.

4.7 Periodic internal and external audits shall be performed to monitor compliance with the quality assurance program. These audits shall be performed in accordance with written procedures and conducted by personnel who do not have responsibility for performing any of the operations being audi ted.

Personnel within the laboratory and data quality perform internal audits on laboratory analytical activities. These internal audits do not supplant the activities of the organizations directed by policy to perform company-wide audits and surveillances, nor does the laboratory QAPP cover them.

4.8 A corrective action program shall be established including criteria for when corrective action is needed, what corrective action will be taken and who is responsible for taking the corrective action.

The laboratories follow the corrective action system defined in WHC-CM-1-3, MRP 5.1, "Corrective Action Management System." In addition, for analytical work the laboratories have an internal quality control system based on the analyses of chemical standards that can initiate a corrective action request. 
4.9. Periodic reports to responsible management shall be prepared on the performance of the enlselons measurements program. These reports should include assessment of the quallty of the data, results of audits and description of corractive actions.

See Section 9.0 of the main body of this report.

4.10 The quality assurance program should be documented in a quality assurance project plan which should address each of the above requirements.

The future Environmental Protection Project Plan and Laboratory Quality Assurance Program Plan will address quality assurance for radioactive airborne emissions sampling and reporting. 


\section{WHC-EP-0536-1}

\section{REFERENCES}

DOE, 1990, Radiation Protection of the Public and the Environment, DOE Order 5400.5, U.S. Department of Energy, Washington, D.C.

EPA, 1991, "National Emission Standards for Hazardous Air Pollutants," Title 40, Code of Federal Regulations, Part 61, U.S. Environmental Protection Agency, Washington, D.C.

LA-218-112

LA-220-103

LA-288-101

LA-348-101

LA-5CS-051

LA-508-052

LA-508-110

LA-508-111

LA-508-114

LA-508-121

LA-542-101

LA-548-11]

LA-549-112

LA-613-111

LA-925-107

LA-943-123

L0-150-115

LQ-508-002

LQ-508-003

LQ-508-005

PM\# 2S18006

WHC-CM-4-15

WHC-CM-5-4

WHC $-\mathrm{CM}-1-3$

WHC-CM-4-3

WHC-CM-4-10

WHC-CM-4-29

WHC-SD-CP-LB-003

Shewhart, 1931, Economic Control of Quality of Manufactured Product, Van Nostrand, New York City, New York. 
WHC-EP-0536-1

\section{APPENDIX H}

\section{METHOD I14 COMPARISON FOR 325 LABORATORY}

M. R. Weiller

Pacific Northwest Laboratory 


\section{WHC-EP-0536-1}

This page intentionally left blank. 
WHC-EP-0536-1

\section{APPENDIX H}

\section{METHOD 114 COMPARISON FOR 325 LABORATORY}

\subsection{Radionuclide Analyals Methods}

A series of methods besed on "principles of measurement" ore described which ore applicable to the analys is of radionuclides collected from alrborne effluent streems at stationary sources. These methode are appl icable only under the conditions stated and within the IImitations described. Som methods specify that only a single radionuclide be present in the sample or the chemically separated semple. This condition should be interpreted to mean that no other radionuclides are present in quantlelus which would interfere with the measurement.

Also identified (Table 1) are methons for selected list of radionuclides. The listed radionuclides are those which are most commonly used and which have the orestest potential for causing dose to members of the public. Use of methods based on principles of measurement other then those described in this section must be approved in advance of use by the Administrator. For radionuclides not listed in Table 1 , any of the described methods may be used provided the user can demonstrate that the applicability conditions of the method have been met.

The type of method applicable to the analysis of a radionuclide is dependent upon the type of radiation emitted, 1.e., alpha, beta or gamm. Therefore, the methods described below are grouped according to principles of measurements for the analysis of alpha, beta and gamme emitting radionuclides.

\subsection{Methods for Alpha Emitting Radionuclides}

\subsubsection{Method A-1, Radiochemistry-Alpha Spectrometry.}

Principle: The element of interest is separated from other elements, and from the semple matrix using radiochemical techniques. The procedure may involve precipitation, ion exchange, or solvent extraction. Carriers (elements chemically similar to the element of interest) may be used. The element is deposited on a planchet in a very thin film by electrodeposition or by coprecipitation on very small amount of carrier, such as lanthanum fluoride. The deposited element is then counted with an alpha spectrometer. The activity of the nuclide of interest is measured by the number of alpha counts in the appropriate energy region. A correction for chemical vield and counting officiency is made using a standardized radioactive nuclide (tracer) of the same element. If adioactive tracer is not available for the element of interest, a predetermined chemical yield factor may be used.

Applicability: This method is applicable for determining the activity of any alpha-enitting radionuclide, regardless of what other radionuclides are present in the sample provided the chemical separation step produces a very thin sample and removes all other radionuclides which could interfere in the spectral region of interest. APHA-605(2), ASTM-D-3972(13).

The sample filter is destroyed by digestion with nitric acid. Activity ratios for any alpha emitters present are determined by alpha spectral analysis of a thin-film deposit prepared by electrodeposition of an al iquot from the digestion from a dimethyl sulfoxide matrix. The alpha spectrometry system consists of alpha spectrometry modules connected to a pulse height analyzer. Activity of individual alpha-emitting nuclides is calculated using the measured alpha activity ratios and a total alpha measurement performed on an aliquot of the digestion solution.

\subsubsection{Method A-2, Radiochemistry-Alpha Counting.}

Principle: The element of interest is separated from other elements, and from the sample matrix using radiochemistry. The procedure may involve precipitation, ion exchange, or solvent extraction. Carriers (elements chemically similar to the element of interest) may be used. The element is deposited on a planchet in a thin film and counted with a alpha counter. A correction for chemical yield (if necessary) is made. The alpha count rate measures the total activity of all emitting radionuclides of the separated element.

Applicability: This method is applicable for the measurement of any alpha-emitting radionuclide, provided no other alpha enitting radionuclide is present in the separated sample. It may also be applicable for determining compliance, when other radionuclides of the separated element are present, provided that the calculated emission rate is assigned to the radionuclide which could be present in the sample that has the highest dose conversion factor. 100-12096(18). 
WHC-EP-0536-1

The technique of chemically separating and individually determining alpha emitting nuclides is employed only when filter sample dissolution produces a solution unsuitable for alpha spectrometry (Method 3.1.1). Counting systems descrlbed for Methods 3.1.1, 3.1.3, and 3.1.5 are employed in alpha counting operations relating to separated nuclides. Where isotopic measurements of a single element are required and the respective alpha energies do not permit satisfactory differentiation, mass spectrometry is employed.

\subsubsection{Method A.3, Direct Alpha Spectrometry.}

principle: The sample, collected on suitable fllter, is counted directly on an alphe spectrometer. The sample must be thin enough and collected on the surface of the fllter so that any abeorption of alphe particle energy in the sample or the fllter, which would degrade the spectrum, is minimal.

Apollcabllity: This method is applicable to simple mixtures of alphe emitting radionuclides and only when the emount of particulates collected on the fllter paper are relatively small and the elphe spectre is edequately resolved. Resolutions should be $50 \mathrm{keV}$ (FWHM) or better, ASTM-D-3084(16).

This method is not used to produce quantitative alpha data. Direct alpha spectral analysis does not provide spectra of satisfactory resolution with currently used filter medla. This method may be used to identify the chemical separations, if any, required when Methods 3.1 .1 and 3.1 .2 are performed.

\subsubsection{Method A-4, Direct Alpha Counting (Gross alpha determination).}

Principle: The sample, collected on a suitable filter, is counted with an alpho counter. The semple must be thin enough so that self-absorption is not significant and the filter must be of such a nature that the particles are retained on the surface.

Applicability: Gross alpha determination may be used to measure emissions of speciflc radionuclides only (1) when it is known that the sample contains only a single radionuclide, or the identity and isotopic ratio of the radionuclides in the sample are well known, and (2) measurements using either Method A-1, A-2 or A-5 have shown that this method provides a reasonably accurate measurement of the emission rate. Gross alphe measurements are applicable to unidentified mixtures of radionuclides only for the purposes and under the conditions described in section 3.7. APHA-601(3), ASTM-D-1943(10).

Filter samples are counted directly in a low background counting system. The system consists of a thin-window gas-flow proportional detector and a gas-flow proportional guard detector operated in anti-coincidence, a high voltage supply, a low/wide beta amp/discriminator, a low/wide beta amp/single channel analyzer, a timer, and two scalers. The system employs pulse height discrimination to differentiate alpha and beta activity. This method is used to screen filter samples for those exhibiting alpha activity levels sufficiently above detection limits to allow application of Method 3.1.1. An alpha scintillation counter employing a zinc sulfide detector is employed to perform alpha measurements on filter samples exhibiting beta/alpha activity ratios high enough to introduce significant uncertainty into alpha results.

\subsubsection{Method A-5, Chemical Determination of Uranium.}

Uranium: Uranium may be measured chemically by either colorimetry or flusorometry. In both procedures, the sample is dissolved, the uranium is oxidized to the hexavalent form and extracted into a suitable solvent. Impurities are removed from the solvent layer. For colorimetry, dibenzoylmethane is added, and the uranium is measured by the absorbance in a colorimeter. For fluorometry, a portion of the solution is fused with a sodium fluoride-lithium fluoride flux and the uranium is determined by the ultraviolet activated fluorescence of the fused disk in a fluorometer.

Applicability: This method is applicable to the measurements of emission rates of uranium when the isotopic ratio of the uranium radionuclides is well known. ASTM-E318(15), ASTM-D-2907(14). 
WHC-EP-0536-1

The sample filter is destroyed by digestion with nitric acid and the resulting solution is analyzed directly in aqueous solution using a pulsed laser fluorimeter.

\subsubsection{Method A-6, Radon-222-Contínuous Gas Monitor.}

Princigle: Radon-222 is measured directly in continuously extracted semple stream by pasaing the - Ir strean through a calibrated scintillation cell. Prior to the acintillation cell, the ir strean fa treated to remove particulates and excess moleture. The alphe particles from radon-222 and its decay products strike. zinc sulfide cooting on the Inside of the scintillation cell producing llght pulses. The light pulses ore detected by photomultipller tube which generates electrical pulses. These pulses are processed by the syatem electronics and the read out is in pCi/l of redon-222.

Apolicability: This method is applicable to the measurement of radon-222 in effluent streems th ch do not contain signfflcant quantities of radon-220. Users of this method should callbrate the monitor in radon calibration chamber at least twice per year. The background of the monitor should al so be checked periodically by operating the instrument in a low radon enviromment. EPA 520/1-89-009(24).

\section{In-line monitoring of effluent air streams is not included in the analytical plan for the segment of the emission monitoring program performed by the Analyticai Chemistry Laboratory.}

\subsubsection{Method A-7, Radon-222-Alpha Track Detectors}

Princigle: Radon-222 is measured directly in the effluent stream using alpha track detectors (ATD). The alpha particles omitted by radon-222 and its decay products strike a small plastic strip and produce submicron damage tracks. The plastic strip is placed in a caustic soluition that accentuates the damage tracks which are counted using a microscope or automatic counting system. The number of tracks per unit area is corrected to the rudon concentration in air using a conversion factor derived from data generated in a radon callibration facillity.

Applicability: Prior approval from EPA is required for use of this method. This method is only applicable to effluent streams which do not contain significant quantities of radon-220, unless special detectors are used to discriminate against radon 220 . This method may be used only when ATOs have been demonstrated to produce data comparable to data obtained with Method A-6. Such date should be submitted to EPA when requesting approval for the use of this method. EPA 520/1-89-009(24).

In-line monitoring of effluent air streams is not included in the analytical plan for the segment of the emission monitoring program performed by the Analytical Chemistry Laboratory.

\subsection{Methods for Gaseous Beta Emitting Radionuclides.}

3.2.1 Method B-1, Direct Counting in Flow-Through Ionization Chambers.

Principle: An ionization chamber containing a specific volume of gas which flows at a given flow rate through the chamber is used. The sample (effluent stream sample) acts as the counting gas for the chamber. The activity of the radionuclide is determined from the current measured in the lonization chamber.

Aoplicability: This method is applicable for measuring the activity of a gaseous beta omitting radionuclide in an effluent stream that is suitable as a counting gas, when no other beta-emitting nuclides are present. DOE/EP-0096(1 7), NCRP-58(23).

In-line monitoring of effluent air streams is not included in the analytical plan for the segment of the emission monitoring program performed by the Analytical Chemistry Laboratory.

\subsubsection{Method B-2, Direct Counting with In-line or Off-line Beta Detectors.}

Principle: The beta detector is placed directly in the effluent stream (in-line) or an extracted sample of the effluent stream is passed through a chamber containing a beta detector (off-line). The activities of the radionuclides present in the effluent stream are determined from the beta count rate, and a knowledge of the radionuclides present and the relationship of the gross beta count rate and the specific radionuclide concentration.

Applicability: This method is applicable only to radionuclides with maximum beta particle energies greater then $0.2 \mathrm{MeV}$. This method may be used to measure emissions of specific radionuclides only when it is known that the sample contains only a single radionuclide or the identity and isotopic ratio of the radionuclides in the effluent stream are well known. Specific radionuclide analysis of periodic grab samples 
WHC-EP-0536-1

may be used to identify the types and quentifles of redionuclides present and to entabliah the relationship between specifle radionuclide analyeses and grose bete count rates.

This method is applicable to unidentifled mixtures of gaseous radionuclides only for the purposes and under the conditions deseribad in section 3.7 .

In-line air stream samples are not included in the analytical plan for the segment of the emission monitoring program performed by the Analytical Chemistry Laboratory.

\subsection{Methods for Non-Caseous Beta Emitting Radionuclides.}

3.3.1 Method 8-3, Radiochemistry-Bete Counting.

Princiole: The element of interest is separated from other elements, and from the semple motrix by rediochemistry. This may involve precipitation, distillation, ion exchange, or solvent extraction. Carriers (elements chemically similar to the element of interest) may be used. The (lement is deposited on a planchet, and counted with a beta counter. Corrections for chemical yield and decay (if necessery) are mada. The bete count rate determines the total activity of all radionucll des of the separated element. This method may also involve the radiochemical separation and counting of a daughter element, after a sultable pariod of ingrowth, in which case it is specifle for the parent nuclide.

Apolicabilltys This method is applicable for measuring the activity of any bete- anitting radionucllde, with a maximum energy greater than $0.2 \mathrm{MeV}$, provided no other radionuclide is present in the separated sample. APHA-608(5).

The sample filter is destroyed by digestion with nitric acid. Betaemitting nuclides are determined by one or more of the following mothods:

- Gamma spectral analysis of a digestion solution aliquot for determination of those nuclides with associated gamma activity

- Beta absorption measurement of a digestion solution aliquot by absorber counting in a gas-flow proportional counter

- Chemical separation of pure beta-emitting nuclides, followed by counting in a gas-fiow proportional counter or liquid scintillation counter (Method 3.3.3).

3.3.2 Method B-4, Direct Beta Counting (Gross beta determination).

Principle: The sample, collected on a suitable filter, is counted with a beta counter. The sample must be thin enough so that self-absorption corrections can be made.

Applicability: Gross beta measurements are applicable only to radionuclides with maximum beta particle energies greater than $0.2 \mathrm{MeV}$. Gross beta measurements may be used to measure emissions of specific radionuclides only (1) when it is known that the sample contains only a single radionuclide, and (2) measurements made using Method B-3 show reasonable agreement with the gross beta measurement. Gross beta measurenents are applicable to mixtures of radionuclides only for the purposes and under the conditions described in Section 3.7. APHA-602(4), ASTM-D-1890(11).

Filter samples are counted directly in a low background counting system. The system consists of a thin-window gas-flow proportional detector and a gas-fiow proportional guard detector operated in anti-coincidence, a high voltage supply, a low/wide beta amp/discriminator, a low/wide beta amp/single channel analyzer, a timer, and two scalers. The system employs pulse height discrimination to differentiate alpha and beta activity. This method is used to screen filter samples for those exhibiting beta activity levels sufficiently above detection 1 imits to allow application of Method 3.2.3. Absorption techniques using a thin absorber are employed to perform beta measurement on filter samplers exhibiting alpha/beta activity ratios high enough to introduce significant uncertainty into beta results. 


\subsubsection{Method B.5, Llquid Scintillation Spectrometry.}

principle: An allquot of collected semple or the result of some other chemical separation or processing technique is added to " llquld scintillation "cocktall" which is vlewed by photomultipller subes in : llquid scintilletion spectrometer. The apectrometer is adjuated to establiah a channol or "window" for the pulse energy approprlate to the nucllde of interest. The activity of the nuclide of interest is measured by the counting rate in the approprlate energy channel. Corrections are made for chemlcal ylelct where separatione are made.

Apollicabllity: This method is applicable to any beta-emitting nuclide when no other redionuclide is present In the semple or the separeted semple provided that it can be Incorporated in the scintillation cocktail. This method is also applicable for samples which contein more than one redionuclide but only when the energies of the bete particles are sufficiently separated so that they cen be resolved by the spectrometer. This mathod is most applicable to the measurement of low-eneroy bete emitters such as tritium and rarbon-14. APHA.609(6), EML LV-539-17(1)).

The sample filter is destroyed by digestion with nitric acid. When a single beta emitter is present, only two low energy beta emitters sufficiently separated in energy for spectral resolution are present, or a chemical separation isolates a single beta-emitting nuclide, the digestion solution is analyzed in a liquid scintillation spectrometer.

\subsection{Gamma Emitting Radionuclides}

3.4.1 Method G-1. HIgh Resolution Garme Spectrometry.

Princlole: The sample is counted with high resolution gamm detector, usually ither Gu(LI) or a high purfity Ge detector, connected to a multichannel analyzer or computer. The gemmo emitting redionuclidas in the sample are measured from the gamme count rates in the energy reglons cheracteristic of the individual radionuclide. Corrections are made for counts contributed by other radionuclides to the spectral reglons of the radionuclides of interest. Radiochemical separations may be made prior to counting but are usually not necessery.

Apolicability: This method is applicable to the measurement of any gamme omitting radionucitide with gamme energies greater than $20 \mathrm{keV}$. It can be applied to complex mixtures of radionuclides. The semples counted may be in the form of perticulate filters, absorbers, liquids or gases. The mothod may also be applied to the analysis of gaseous gama emitting radionuclides directly in on effluent strean by passing the stream through a chamber or cell containing the detector. ASTM-3649(9), 100-12096( 18).

Filter and charcoal cartridge samples are counted directly on a highresolution intrinsic germanium detector. The system consists of the detector, a bias supply, a spectrometry amplifier, an analog-to-digital converter, and a pulse height analyzer linked to a multiuser system.

\subsubsection{Method G-2, Low Resolution Gamma Spectrometry.}

princiole: the sample is counted with a low resolution gamma detector, a thallium activated sodium iodide crystal. The detectur is coupled to a photomultiplier tube and connected to a multichannel analyzer. The gamma emitting radionuclides in the sample are measured from the gamma count rates in the energy regions characteristic of the individual radionuclides. Corrections are made for counts contributed by other ra* dionuclides to the spectral regions of the radionuclides of interest. Radiochemical separation may be used prior to counting to obtain less complex gamma spectra if needed.

Applicability: This method is applicable to the measurement of ganme emitting radionuclides with energies greater than $100 \mathrm{keV}$. It can be applied only to relatively simple mixtures of gamme emitting radionuclides. The samples counted may be in the form of particulate filters, absorbers, liquids or gas. The method can be applied to the analysis of gaseous radionuclides directly in an effluent strean by passing the gas stream through a chamber or cell containing the detector. ASTM-D-2459(12), EMSL-LV-0539-17(19).

Charcoal cartridge samples are counted directly on a 4-in. by 5-in thallium-activated sodium iodide detector. The system consists of the detector, a high voltage supply, a preamplifier, a linear amplifier, an analog-to-digital converter, and a pulse holght analyzer linked to a multiuser system. This method is used to screen charcoal cartridge samples for those samples exhibiting gamma activity levels sufficiently above detection limits to permit gamma component identification by highresolution gamma spectrometry. 


\subsubsection{Method 0.3, single Channal Oemm spectromery.}

Reinaloles the semple le counted with thalllum aetivated eadiu lodide orvetel. The deteeter lo

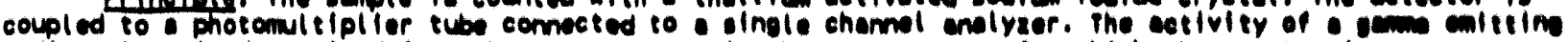

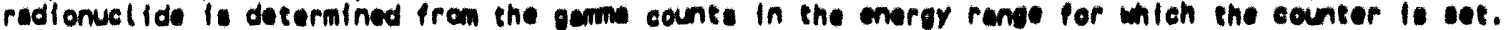

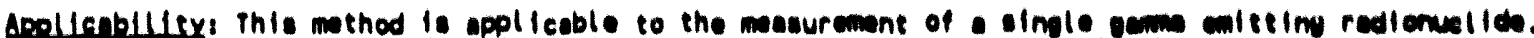
It ls not apolteeble to mixtures of redlonuclldes. The semples counted may be in the form of partleulate

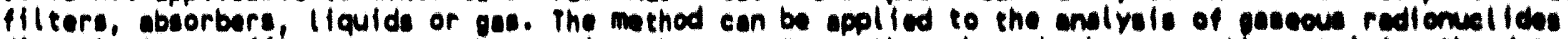

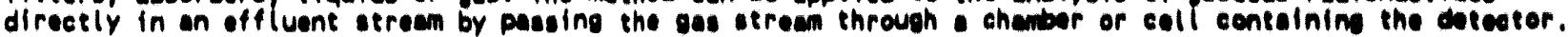

\section{Single channel ganma spectrometry is not employed at the Analytical Chemistry Laboratory.}

\subsubsection{Mathod 0.4, Orose oemm counting.}

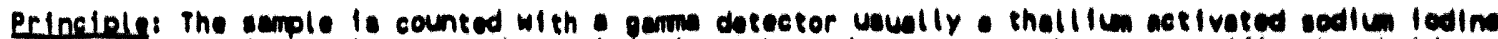

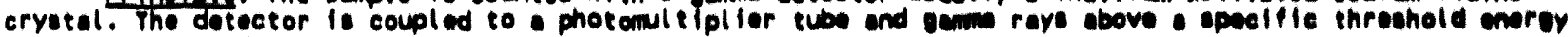
level ore counted.

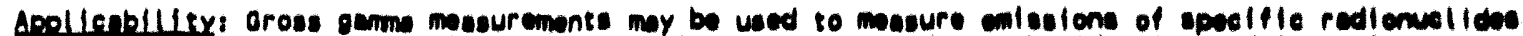

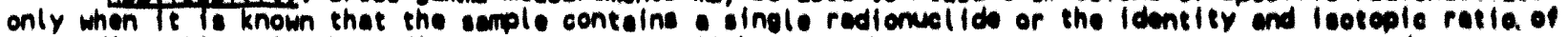

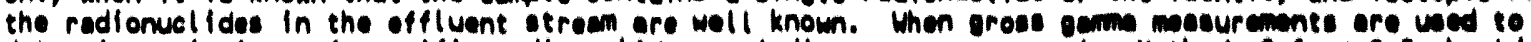

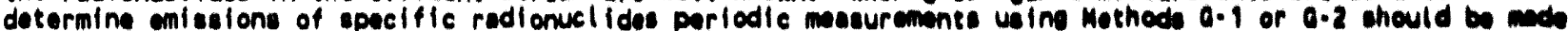

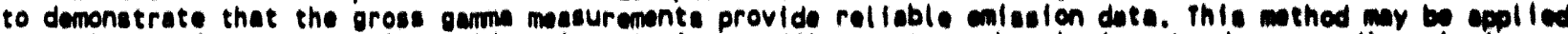
to analyeis of gaseous redionuclides directly in an effluant strecen by plecine the detector direesly in or adjacent to the effluent strean or passing on extracted anple of the effluent strocen through a chember or cell conteining the detector.

Gross gamma counting techntques are not included in the anelytical plan for the segment of the emisstons monitoring program performod by the Analytical Chemistry Laboratory.

3.5 Counting Methods. All of the mothods with the except Ion of Mothod $A .5$

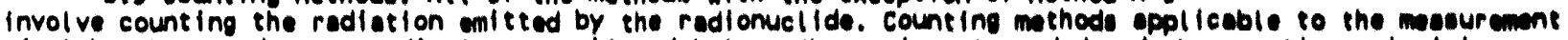
of alpha, beta and gamm radiations are listed below. The equipment meded and the counting prinelples involved are described in detall in AstM-3648(8).

\subsubsection{Alpha Counting:}

- Ges flowproportlonel counters. The elphe particles cause ionization in the counting and the resulting electrical pulses are counted. These counters may be windowl ase or have very thin windows.

escintillation counters. The alphe particles transfor eneroy to a scintillator resulting in production of Tight photons which strike - photomultiplier tube converting the light photonn to eleetrleal pulses which are counted. The counters may involve the use of solid ecintillation materlals such is tine sulfide or llquid scintillation solutione.

asolld-state counters. Semiconductor materiale, wch as sillicon surface-barpler pen Junctions, act os solid Ionization chambers. The olpha particles interect which the detector producing electron hole pairs. The charged peir is collected by an applied electrical field and the resulting electrical pulses are counted.

alohe Spectrometers. Semiconductor detectors used in conjunction with multichamal onalyzers for energy discrimination.

- Gas-Flow Proportional Counters. A thin-window gas-flow proportional counting system is employed to perform Mothods 3.1.2 and 3.1.4.

- Scintillation Counters. An alpha scintillation counter equippod with a zinc sulfide detector may be employed to perform Method 3.1.4.

- Solid State Counters. Solid state semiconductor detectors are employed in alpha spectrometry Methods 3.1 .1 and 3.1 .3 and in gross alpha measurements assoctated with Mothods 3.1.2 and 3.1.4. 
- Alpha Spectrometers. Solid state semiconductor detector equipped pulse helght analyzers are employed to perform Methods 3.1 .1 and 3.1.3.

- Llquid Scintillation Spectrometers. Liquid scintillation spectrometer systems designed to discriminate between alpha, beta, and gamma activity on a pulse shape basis and on a pulse amplitude basis are operational at the Analytical Chemistry Laboratory, though nelther are currently included in the analytical plan for the environmental monitoring program.

\subsubsection{Bota Countings}

elenlution chambars. These chambers contain the seta-emitting ruclide in yaseous form. The ionizotion curront produced is measured.

anden-Muller (OM) Counters-or Gas flow Proportional Counters. The beta particles cause ionization In the counting ges and the resulting electrical pulses are counted. Proportional gas flow counters thich are heavily shlelded by lead or other metal, and provided with an anti-coincidence shield to reject cosmic rays, ore called low background beta counters.

uscintlllation counters. The beta particles transfer energy to a scintillator resulting in a production of tight photons, which strike a photomultiplier tube converting the light photon to electrical pulses thich are counted. This may involve the use of anthracene crystals, plastic scintillator, or liquid seintillation solutions with organic phosphors.

whould seintilletion spectrometers. Liquid scintillation counters which use two photomultiplier tubese in colncidence to reduce beckground counts. This counter may also electronically discriminate anong pulces of a given range of energy.

- Ionization Chambers. The analytical plan for the segment of the emissions monitoring program performed by the Analytical Chemistry Laboratory does not include samples suited to this counting technique.

- Gas-Flow Proportional Counters. A thin window gas-flow proportional counting system is employed to perform Methods 3.3.1 and 3.3.2.

- Scintillation Counters. Solid state beta scintillation detectors are not currently included in the analytical plan for the segment of the emissions monitoring program performed by the Analytical Chemistry Laboratory.

- Liquid Scintillation Spectrometer. Liquid scintillation spectrometer systems designed to discriminate between alpha, beta, and gamma activity on a pulse shape basis are not currently operational at the Analytical Chemistry Laboratory. Scintillation techniques that discriminate between alpha and beta activity on a pulse height basis are not included in the analytical plan for the emissions monitoring program performed at the Analytical Chemistry Laboratory.

3.5.3 Gamma Counting:

Low-8esolution Gamma Spectrometers. The gamma rays interact with thallium activated sodium iodide or cesium iodide crystal resulting in the release of light photons which strike a photomultiplier tube convertIng the light pulses to electrical pulses proportional to the energy of the gamma ray. Multi-channel analyzers are used to separate and store the pulses according to the energy absorbed in the crystal.

aHiah-Resolution gamma Spectrometers. Gamma rays interact with a (ithium-drifted (Ge(Li)) or nigh-purity germanium (HPGe) semiconductor detectors resulting in a production of electron-hole pairs. The charged pair is collected by an applied electrical field. A very stable low noise preamplifier amplifies the pulses of lectrical charge resulting from the gamma photon interactions. Multichannel analyzers or computers are used to separate and store the pulses according to the energy absorbed in che crystal. 
WHC-EP-0536-1

-Single Channel Analyzers. Thallium activated sodium iodide crystals used with a single window analyzer. Pulses from the photomultiplier tubes are separated in a single predetermined energy range.

- Low Resolution Gamma Spectrometers. A 4-in. by 5-in. thalliumactivated sodium iodide detector is employed to perform Method 3.4.2.

- High Resolution Gamma Spectrometer. A high-resolution intrinsic germanium detector is employed to perform Method 3.4.1.

- Single Channel Analyzers - Single channel gamma spectrometry is not included in the analytical plan for the emissions monitoring program performed at the Analytical Chemistry Laboratory.

3.5.4 Calibration of Counters. Counters are calibrated for specific radionuclide measurements using a standard of the radionuclide under either identical or very similar conditions as the semple to be counted. For gamm spectrometers a series of standards covering the energy range of interest may be used to construct a calibration curve relating gamma energy to counting efficiency.

In those cases where a standard is not available for a radionuclide, counters may be calibrated using a standard with energy characteristics as similar as possible to the radionuclide to be measured. For gross alpha and beta measurements of the unidentified mixtures of radionuclides, alphe counters are cal ibrated with a natural uranium standard and beta counters with a cesium-137 standard. The standard must contain the same weight and distribution of solids as the samples, and be mounted in an identical manner. If the samples contain variable amounts of solids, calibration curves relating weight of solids present to count ing efficiency are prepared. Standards other than those prescribed may be used provided it can be shown that such standards are more applicable to the radionuclide mixture measured.

The thin-window gas-flow proportional counter that is used for filter sample screening for positive amounts of alpha and beta activity using Methods 3.1 .4 and 3.3 .2 is calibrated for the alpha-emitting nuclide ${ }^{239} \mathrm{Pu}$ and beta-emitting nuclides ${ }^{90} \mathrm{SrY},{ }^{99} \mathrm{Tc}$, and ${ }^{137} \mathrm{Cs}$ using National Institute of Standards and Technology (NIST) traceable standard reference materials fabricated into the filter sample counting geometry configuration. Efficiency data measured for ${ }^{239} \mathrm{Pu}$ have been demonstrated to be applicable to all alpha energies greater than $4.0 \mathrm{MeV}$. The analytical program specifies that all net beta measurement amounting to less than the 2 sigma uncertainty in the measured beta counting background will be reported as less than a detection limit based on that 2 sigma quantity and calculated as ${ }^{90} \mathrm{SrY}$. Gross beta results for filter samples exhibiting positive beta activity are calculated using an efficiency that is weighted according to components identified in the sample using Method 3.3.1.

The high-resolution gamma ray spectrometry system that is used for quantitative gamma spectral analysis of filter and charcoal cartridge samples, Method 3.4.1, is efficiency calibrated using a mixed nuclide certified standard and individual NIST traceable standard reference solutions of ${ }^{60} \mathrm{Co},{ }^{131} \mathrm{I},{ }^{133} \mathrm{Ba},{ }^{137} \mathrm{Cs}$, and ${ }^{152} \mathrm{Eu}$ fabricated into the charcoal cartridge counting geometry configuration. The emissions monitoring program plan (PNL 1990) specifies that charcoal cariridge samples exhibiting no ${ }^{131} \mathrm{I}$ activity at the $364 \mathrm{KeV}$ principal gamma energy shall be reported as containing less than an ${ }^{131}$ I detection 1 imit calculated using the 2 sigma uncertainty in the measured spectrum background at that energy.

3.6 Radiochemical Methods for Selected Radionuclides. Methods for a selected list of radionuclides are listed in Table 1. The radionuclides listed are those which are most comonly used and which hove the greatest potential for causing doses to members of the public. For radionuclides not listed in Table 1 , 
methods based on any of the applicable "principles of measurement" described in Section 3.1 through 3.4 may be used.

Filter and charcoal cartridge samples found to contain significant alpha, beta, or gamma activity components during screening under Methods 3.1.4, 3.3.2, and 3.4 .2 that cannot be quantitatively determined by gamma spectral analysis using Method 3.4.1 are analyzed using counting Methods 3.1.1, 3.1.2, and 3.3.1. Volume 7 of the Analytical Chemistry Laboratory Manual (PNL 1990) contains established procedures for separation and measurement of selected radionuclides not specific to the emissions monitoring program plan that can be applied to filter and charcoal sample anaiysis.

3.7 Applicability of Gross Alpha and Beta Measurements to Unidentified Mixtures of Radionuclides. Gross alpha and beta measurements may be used as a screening measurement as a part of an emission measurement program to identify the need to do specific radionuclide analyses or to confirm or verify that unexpected radionuclides are not being released in significant quantities.

Gross alpha (Method A-4) or gross beta (Methods B-2 or B-4) measurements may also be used for the purpose of comparing the messured concentrations in the effluent stream with the limiting "Concentration Levels for Environmental Compliance" in Table 2 of Appendix E. For unidentified mixtures, the measured concentration value shall be compared with the lowest environmental concentration limit for any radionuclide which is not known to be absent from the effluent stream.

Methods 3.1 .4 and 3.3 .2 gross activity measurements are used only as a screening procedure to identify those filter samples containing significant amounts of alpha and beta activity, respectively. Detection limit values calculated using the 2 sigma uncertainty in the respective measured backgrounds are reported for samples exhibiting net activities less than these uncertainties.

\subsection{Qual ity Assurance Methods}

Each facility required to measure their radionuclide emissions shall conduct a quality assurance program in conjunction with the radionuclide emission measurements. This program shall assure that the emission measurements are representative, and are of known precision and accuracy and shall include administrative controls to assure prompt response when emission measurements indicate unexpectedly large emissions. The program shall consist of a system of policies, organizational responsibilities, written procedures, data quality specifications, audits, corrective actions and reports. This quality assurance program shall include the following program elements:

4.3.5 A description of the laboratory analys is procedures used for each radionuclide measured. including frequency of analysis calibration procedures and frequency of calibration.

Particulate matter filter samples and gaseous material charcoal absorption samples are collected from the various sampling sites on a scheduled, usually weekly, bas is by Westinghouse Hanford personnel. These samples are delivered to the Analytical Chemistry Laboratory, 325 Building, 300 Area.

Calibration procedures for all counting instruments employed in the performance of analytical measurements described for emission monitoring program samples in Volume 6 of the Analytical Chemistry Laboratory Manual are documented in that manual (PNL 1990).

The filter and charcoal cartridge samples that constitute the Analytical Chemistry Laboratory emissions monitoring program rarely exhibit positive gross alpha, gross beta, or gamma activity, excepting naturally occurring radon daughter activity when certain atmospheric conditions exist. For samples exhibiting net activities less than the 2 sigma uncertainty of 
WHC-EP-0536-1

the applicable counting instrument measured background, these 2 sigma uncertainties are used to calculate maximum possible limits for possible alpha, beta, and gamma emissions. Calculation conventions for gross count data are cescribed in Table II, Section 3.5.4, Calibration of Counters (PNL 1990).

Filter samples exhibiting net alpha activity greater than the 2 sigma uncertainty in the measured beta counting system background are quantitatively analyzed by chemical destruction of the filter medium followed by direct total alpha and alpha spectral measurement of the resulting solution.

Filter samples exhibiting net beta activity greater than the 2 sigma uncertainty in the measured alpha counting system background are quantitatively analyzed by direct high-resolution gamma ray spectrometry. When data indicate possible presence of pure beta-emitting radionuclides in a filter sample, quantitative analytical methods for ${ }^{90} \mathrm{SrY},{ }^{99} \mathrm{TC}$, and ${ }^{47} \mathrm{Pm}$, documented in Volume 7 of the Analytical Chemistry Laboratory Manual (PNL 1990) are performed.

4.5 A quality control program shall be established to evaluate and track the quality of the emissions measurement data against preset criteria. The program should include where applicable a system of replicates, spiked samples, split samples, blanks and control charts. The number and frequency of such quality control checks shall be identified.

Quality control procedures governing calibration and control of counting instruments employed in the emissions monitoring program are documented in the Analytical Chemistry Laboratory Manual, PNL-MA-599, Vol. 5. Counting instrument performance is monitored by the use of "control" sources consisting of selected radionuclides exhibiting energy range extremes which are established simultaneously with instrument

calibration. Control sources are remeasured daily; so long as a control measurement result falls within 3 sigma 1 imits established for the original control data, instrument calibration is assumed to remain valid. Should a control count exceed a 2 sigma limit, a remeasurement is performed; should both measurements fall outside a 3 sigma limit, the instrument is referred to a cognizant scientist for further testing and referral to instrument repair services. When an instrument is returned to service, it is recalibrated and new controls are established. Alpha proportional counting systems are controlled usijng ${ }^{239} \mathrm{Pu}$ sources, alpha spectral analyzers with a mixed ${ }^{237} \mathrm{~Np}+{ }^{239} \mathrm{Pu}+{ }^{24} \mathrm{Am}$ squrce, and beta proportional counting systems with individual ${ }^{99} \mathrm{Tc},{ }^{147} \mathrm{Pm}$, and ${ }^{90} \mathrm{SrY}$ sources. High resolution gamma spectral analyzers are controlled with either a mixed ${ }^{241} \mathrm{Am}+{ }^{37} \mathrm{Cs}+{ }^{60} \mathrm{Co}$ source or a ${ }^{152} \mathrm{Eu}+{ }^{137} \mathrm{Cs}+{ }^{60} \mathrm{Co}$ source, while low resolution gamma spectral analyzers are controlled with individual ${ }^{57} \mathrm{Co}$ and ${ }^{60} \mathrm{Co}$ sources.

Counting system backgrounds are measured at least once each working day; long background measurements are performed over weekends.

A control chart is used to evaluate current performance of each counting instrument and to identify trends in performance. Control of each instrument is determined at least once each working day before the instrument is used. All calibration data, control data, and background data are recorded directly into a laboratory record book dedicated to 


\section{WHC-EP-0536-1}

that specific instrument. Control charts and instrument maintenance and repair records are included in the same volume.

The individual procedures for quantitative determination of specific nuclides documented in Volume 7 of PNL (1990) specify replicate anaiysis, internal standards, and other quality-related operations in performance of radiochemical analysis where applicable.

\section{REFERENCE}

PNL, 1990, Analytical Chemistry Laboratory Manual, Volumes 6 and 7, PNL-MA-597, Pacific Northwest Laboratory, Richland, Washington. 
WHC-EP-0536-1

This page intentionally left blank. 
WHC-EP-0536-1

\section{APPENDIX I}

METHOD 114 COMPARISON FOR STACK 291-T-1

To be determined by J. H. Mizner, Jr. 
WHC-EP-0536-1

This page intentionally left blank.

- 
WHC-EP-0536-1

\section{DISTRIBUTION}

Number of copies

OFFSITE

4

U. S. Environmental Protection Agency. Region 10 1200 Sixth Avenue

Seattle, Washington 98101

J. M. Lietch

AT-081

F. J. McCormick

AT -081

G. L. O'Ne11

AT -081

R. W. Poeton

AT -081

1

U. S. Environmental Protection Agency. Region 10 712 Swift Boulevard, Suite 5

Richland, Washington 99352

P. T. Day

2

Washington State Department of Health 01ympia, Washington 98504-0095

A. W. Conkl in

K. Fox-Williams

5

U. S. Department of Energy. Bichland Operations office

C. E. Clark

A5-15

M. J. Furman

J. E. Rasmussen

A5-21

S. D. Stites

A5-15

Public Reading Room

A5-19

A $1-65$

\section{ONSITE}

Pacific Northwest Laboratory

PNL Technical Files

$k 1-11$

72

Westinghouse Hanford Company

D. Alison

T5-54

J. M. Barnett

T1-30

J. A. Bates

H6-22

$T$. Bennington

H4-16

Distr-1 


\section{DISTRIBUTION (Continued)}

ONSIIE Westinghouse Hanford Company (Continued)

L. D. Berneski

L4-96

R. J. BI Iss

B3-04

R. J. Boom

T1 -30

R. J. Bottenus

T3-28

M. J. Brown

S. A. Burris

H6-20

G. D. Carpenter

T1-30

J. E. Cottre11

P. J. Crane

G. M. Crummel

B. L. Curn

A. K. Dasgupta

H6-30

T7 -20

T3-28

$\mathrm{R} 1-51$

$X 0-21$

T6-50

G. M. Davis

W. E. Davis

$\times 1-80$

L. P. Diediker (5)

H6-30

B. G. Erl andson

T1 -30

H6-2O

D. G. Farwick

$\mathrm{H} 4-16$

G. W. Faulk

A. J. Fisher

T3-28

T. P. Frazier

A4-79

$\mathrm{T} 1-30$

K. A. Gano

$\times 0-21$

J. L. Gilbert

โ7-97

E. M. Greager

H6-30

M. L. Grygiel

B1-58

R. D. Gustavson

$\mathrm{R} 1-51$

D. L. Halgren

S6-70

D. G. Hamrick

R1-51

G. W. Jackson

H6-21

D. B. Jensen

H6-30

D. L. Johnson

S6-19

R. E. Johnson

$\mathrm{T} 1-30$

J. R. Kasper

R2-50

J. G. Kristofzski

T6-06

R. J. Landon

H6-22

R. E. Lerch

J. Lohrasbi

R. P. Marshall, Jr.

B3-63

S6-19

P. J. Martell

J. C. Midgett

T6-14

T1-30

S6-15

J. H. Mizner, Jr.

T3-28

R. D. Moerman

B5-20

J. M. Nickels

H6-22

J. K. Perry

H6-20

J. A. Rivera

B2-16

J. D. Schaffer

S. T. Smith

N1-71

M. W. Stevenson

H4-25

S. P. Thomas (2)

B2-35

L. W. Vance

T1 -30

H4-16 


\section{WHC-EP-0536-1}

\section{DISTRIBUTION (Continued)}

ONSIIE Westinghouse Hanford Company (Continued)

S. A. Vega

L4-86

C. L. Volkman

T4-10

D. D. Volkman

$\mathrm{H} 4-25$

E. C. Vogt

T5-50

M. R. Wetler

R. D. Weissenfels

P7-22

C. D. Woll am

$56-70$

Central Files

$56-19$

L8-04

Correspondence Control

A3-01

Document Processing \& Distribution (2)

EDMC

L8- 15

Information Release Administration (3)

H4-22

RI-08 
WHC-EP-0536-1

This page intentionally left blank. 

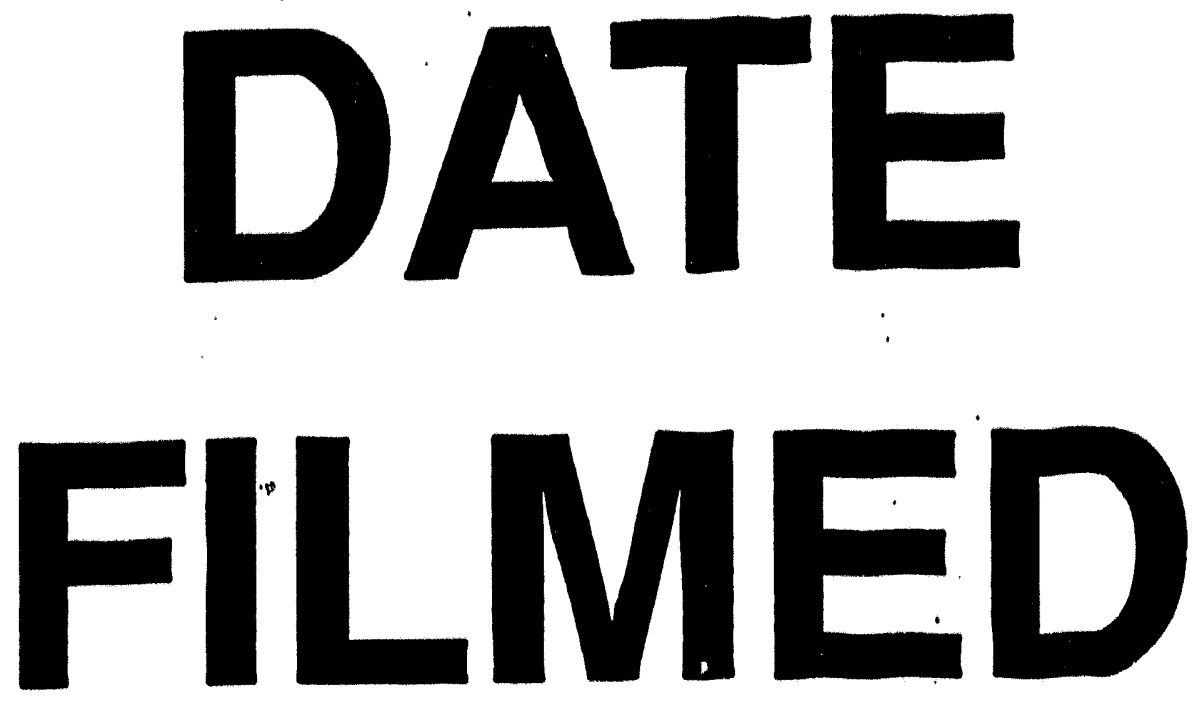

12
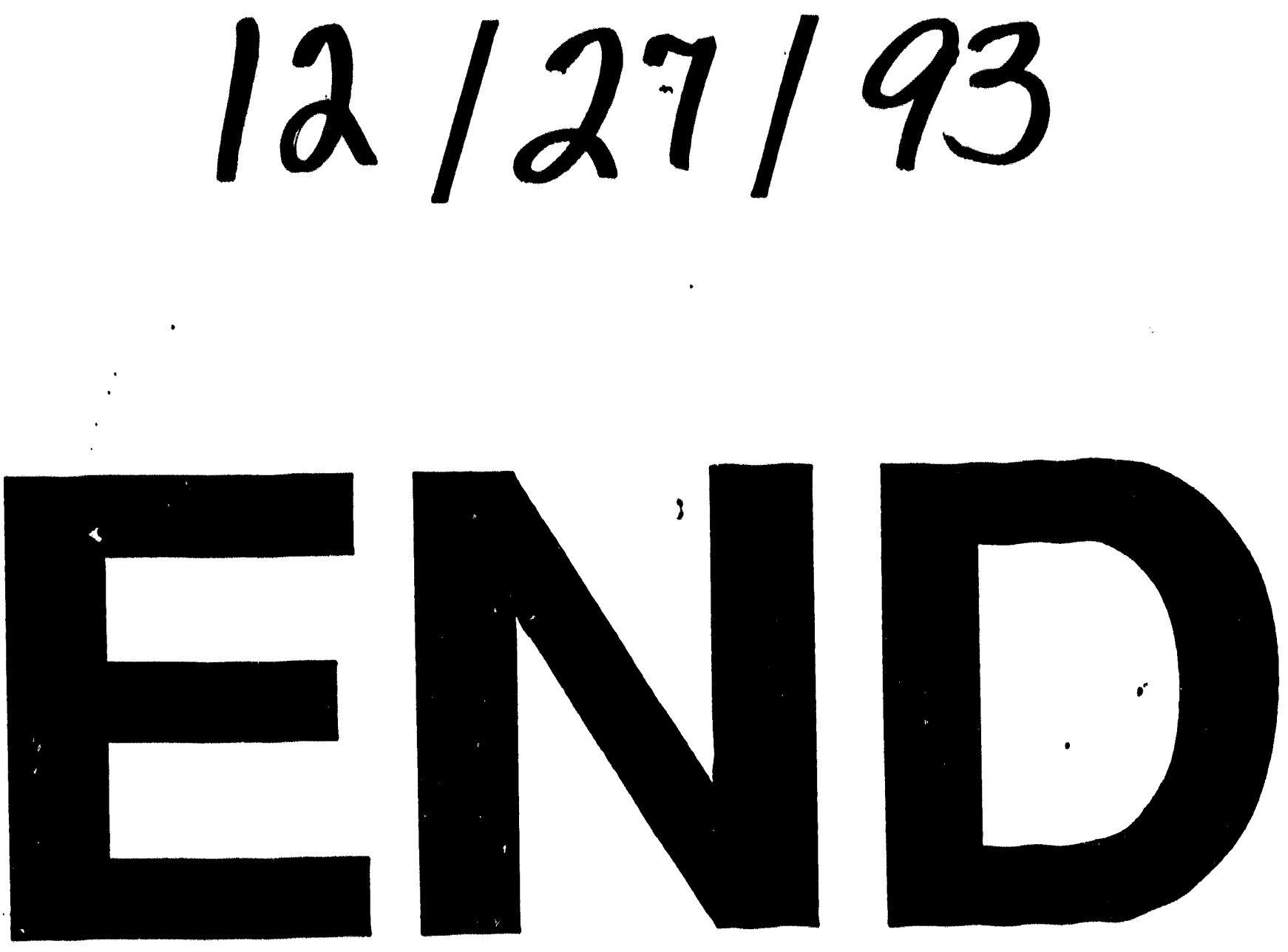
